\title{
De biologie en methodologie van aanleg en omgeving
}

Citation for published version (APA):

Smit, H. E. (1989). De biologie en methodologie van aanleg en omgeving. [Doctoral Thesis, Maastricht University]. Wolters-Noordhoff. https://doi.org/10.26481/dis.19891020hs

Document status and date:

Published: 01/01/1989

DOI:

10.26481/dis.19891020hs

Document Version:

Publisher's PDF, also known as Version of record

\section{Please check the document version of this publication:}

- A submitted manuscript is the version of the article upon submission and before peer-review. There can be important differences between the submitted version and the official published version of record.

People interested in the research are advised to contact the author for the final version of the publication, or visit the DOI to the publisher's website.

- The final author version and the galley proof are versions of the publication after peer review.

- The final published version features the final layout of the paper including the volume, issue and page numbers.

Link to publication

\footnotetext{
General rights rights.

- You may freely distribute the URL identifying the publication in the public portal. please follow below link for the End User Agreement:

www.umlib.nl/taverne-license

Take down policy

If you believe that this document breaches copyright please contact us at:

repository@maastrichtuniversity.nl

providing details and we will investigate your claim.
}

Copyright and moral rights for the publications made accessible in the public portal are retained by the authors and/or other copyright owners and it is a condition of accessing publications that users recognise and abide by the legal requirements associated with these

- Users may download and print one copy of any publication from the public portal for the purpose of private study or research.

- You may not further distribute the material or use it for any profit-making activity or commercial gain

If the publication is distributed under the terms of Article $25 \mathrm{fa}$ of the Dutch Copyright Act, indicated by the "Taverne" license above, 


\section{De biologie en methodolo- gie van aanleg en omgeving}

\section{Proefschrift}

ter verkrijging van de graad van doctor aan de Rijksuniversiteit Limburg te Maastricht op gezag van de Rector Magnificus Prof. Dr. F.I.M. Bonke, volgens het besluit van het College van Dekanen, in het openbaar te verdedigen op vrijdag 20 oktober 1989 om 16.00 uur

door

Hendrikus Egbertus Smit geboren op 22 juli 1955 te Almelo 
Promotoren

Beoordelingscommissie
Prof. Dr. L. Boon

Prof. Dr. ir. G.H. de Vries

Prof. Dr. M.A. van den Hout Dr. W.G. Callebaut Prof. Dr. J.A.R.A.M. van Hooff Dr. T. Meijering Prof. Dr. P J. Thung 


\section{Harry Smit}

\section{De biologie en methodologie van aanleg en omgeving}


Ter nagedachtenls aan mijn vader, Ben Smit 


\section{Inhoud}

Voorwoord 9

1

Aanleg en omgeving 11

1.1 Inleiding 11

1.2 De Zoeklichttheorie en de Emmertheorie 13

1.3 Deductivisme en inductivisme 18

1.4 Onderzoeksplan 24

2

Methodologische stijlen 30

2.1 Inleiding 30

2.2 De deductieve stijl 32

2.3 Popper en de inductieve stijl 33

2.4 De ontdekking van penicilline 37

2.5 Puzzeloplossen 42

2.6 Methodologie en onderzoekspraktijk 45

2.7 Slot 48

3

De ontwikkeling van gedrag

De controverse tussen ethologen en behavioristen 50

3.1 Inleiding 50

3.2 Incommensurabiliteit 52

3.3 Achtergronden 54

3.4 Twee disciplinaire matrices 59

3.5 Het onderzoek van Kuo 62 
3.6 De eerste controverse 65

3.7 Gedragsembryologie 71

3.8 De tweede controverse 73

3.9 Het discriminatievermogen van pekingeenden 77

3.10 Aanleg, omgeving en interactionisme 80

3.11 Slot 85

4

Fenomenen en theorieên

De Emmertheorle, de Zoeklichttheorle en Wittgenstein 88

4.1 Inleiding 88

4.2 Popper en de Wiener Kreis 90

4.3 Regels zijn de maat van alle dingen 93

4.4 Samples 102

4.5 Samples, regels en puzzeloplossen 109

4.6 Samples, methodologische stijlen en theorieën 113

4.7 Conclusies 119

5

Socloblologie

De wiskundige benadering van gedrag 122

5.1 Inleiding 122

5.2 Proximate en Ultimate theorieën 124

5.3 Speltheorie 127

5.4 Sociobiologie versus ethologie 131

5.5 Conclusies 137

6

Immunologie tussen structuur en functie 140

6.1 Inleiding 140

6.2 Voorgeschiedenis 142

6.3 De analogie met adaptieve enzymen 147

6.4 Natuurlijke en klonale selectie 151

6.5 Immunochemie en genetica 156

6.6 Conclusies 162 
Aanleg, omgeving en gedrag 165

\subsection{Inleiding 165}

7.2 Humane ethologie en sociobiologie 166

7.3 Ethologie en psychologie 171 .

7.4 Behaviorisme en mentalisme; vorm en functie $\mathbf{1 7 5}$

7.5 Het intelligentie-onderzoek 178

7.6 Aanleg, omgeving en culturur 180

7.7 Conclusies 183

8

Controversiële problemen, oplosbare puzzels

De biologie en methodologie van aanleg en omgeving 185

\subsection{Inleiding 185}

8.2 Consensus en conflict 186

8.3 De Zoeklichttheorie en de Emmertheorie 'revisited' 188

8.4 Aanleg en omgeving in de levenswetenschappen 192

8.5 Slot 195

Noten 199

Verklarende woordenlijst 211

Personenregister 216

Zakenregister 217

Summary 219

Over de auteur 223 



\section{Voorwoord}

Zoals een van mijn vroegere leermeesters het stelde: elk biologisch produkt kan tot leven komen dank zij de genetische basis die het aan het begin van de ontwikkeling mee krijgt, en dank zij het milieu waarin het zich kan ontplooien. Dit intellectueel produkt is op analoge wijze tot stand gekomen. De bijdrage die mijn ouders hebben geleverd, wordt door deze biologische slagzin mooi weergegeven - hen dank ik voor de aanleg én voor de opvoeding. Over de aanleg zal ik zwijgen, maar over de intellectuele omgevingsinvloeden kan concrete informatie worden gegeven. De belangrijkste stimuli wil ik hier bedanken.

In de periode dat ik biologie studeerde aan de Rijksuniversiteit Groningen heb ik, meer dan ik mij toendertijd realiseerde, veel geleerd van Prof.Jaap Kruyt, Dr. Herman Rijksen en Dr. Joost Tinbergen. Door hen werd mijn belangstelling voor het aanleg-omgeving vraagstuk gewekt en zonder deze stimulerende invloeden zouden de hoofdstukken 3 en 5 vermoedelijk nooit tot stand zijn gekomen. Tijdens mijn studie filosofie aan de Rijksuniversiteit Groningen heb ik veel gehad aan discussies met Prof. Else Barth. Haar invloed is merkbaar in hoofdstuk 3. In de twee jaar dat ik werkzaam was bij de Faculteit der Wiskunde en Natuurwetenschappen van de Katholieke Universiteit Nijmegen moeten vooral mijn toenmalige begeleiders Prof. Guy Debrock en Prof. Paul Scheurer worden genoemd. Met hen heb ik vruchlbare discussies gevoerd over hardnekkige natuurwetenschappelijke en filosofische problemen. Het was ook in deze periode dat Dr. Peter Hacker mijn toenmalige wetenschapsbeeld tijdens gesprekken in Oxford radicaal verstoorde. Dit heeft zijn weerslag gehad in mijn onderzoek en resulteerde uiteindelijk in hoofdstuk 4 van deze studie.

In dit werk wordt het aanleg-omgeving vraagstuk onderzocht, maar ook de werkwijze van onderzoekers in de levenswetenschappen die dit vraagstuk bestuderen. Een aantal van hen is zo vriendelijk geweest vragen over hun onderzoek schriftelijk of mondeling te beantwoorden. Daarvoor wil ik onder meer Prof. Gilbert Gottlieb, emiritus-Prof. Victor Hamburger, emiritus-Prof. Niels Jerne, Prof. Ronald Oppenheim en Dr. Johan van Rhijn op deze plaats bedanken. 
Het onderzoek werd afgerond tijdens mijn werkzaamheden bij de vakgroep Gezondheidsethiek en Wijsbegeerte van de Rijksuniversiteit Limburg, De leden van het project Onderzoek van Gezondheidswetenschappen en Gezondheidstechnologie' hebben in deze periode delen van dit werk kritisch besproken, waarvoor ik hen hier wil bedanken.

Prof. Gerard de Vries is van meet af aan betrokken geweest bij het onderzoek. Aan zijn ideeên, kritiek en commentaar heb ik veel gehad. Voortdurend wist hij mijn problemen te verhelderen door ze in een adequate terminologie te herformuleren, zodat elke discussie vruchtbaar was. Dat laatste geldt ook voor Prof. Louis Boon, wiens ideeën bepalend zijn geweest voor de opzet en uitvoering van deze studie. Onbedoeld en vooral ongewild bevestigt zijn invloed Wittgensteins these dat het moeilijk is slechts weinig af te wijken van paden die al vaak zijn betreden.

Ten slotte geldt mijn dank Ingrid Lathouwer en Elly Meertens, die delen van het manuscript hebben uitgetypt. De aanwezigheid van Waltje was eerst een trigger, later een stimulus, en nog later onontbeerlijk.

Maastricht, 1989 


\title{
1
}

\section{Aanleg en omgeving}

\author{
1.1
}

Inleiding

In 1957 publiceerde de Australische immunoloog F.M. Burnet 'A modification of Jerne's theory of antibody production using the concept of clonal selection'. ${ }^{1}$ Achteraf bezien is dit artikel én van de belangrijkste bijdragen geweest aan de immunologie in deze eeuw. Burnet ontwikkelde in zijn artikel een aanlegtheorie over de immunologische response die de toendertijd met name onder chemici gangbare instructietheorie zou moeten vervangen. Volgens Burnet fungeerden antigenen niet als stimuli voor de immunologische reactic, maar als 'triggers'. Organismen leren antigenen niet herkennen, zoals in de instructietheorie werd gesteld, maar beschikken volgens Burnet over een genetisch gereguleerd mechanisme waardoor zij in staat zijn antilichamen te vormen die zich kunnen binden met antigenen. Immuniteit ontstond dus niet na contact met het antigeen, zoals instructietheoretici dachten, maar was volgens Burnet al in beginsel aanwezig vóordat organismen in aanraking komen met antigenen.

De overgang van de instructietheorie naar de klonale selectietheorie betekende een conceptuele breuk in de immunologie: een omgevingstheorie werd vervangen door een aanlegtheorie. $\mathrm{Zij}$ maakte de weg vrij voor een periode van spectaculaire kennisgroei waardoor de immunologie: 'the most popular and the most glamorous of the biological sciences' werd ${ }^{2}$ Natuurlijk was er voor deze spectaculaire kennisgroei méér nodig dan een conceptuele transformatie: zij vereiste ook nieuwe technieken, methodieken en instrumenten. Maar dat was het handwerk, het invullen van een kaart waarvan de blauwdruk door Burnet was ontworpen. De rand van de puzzel was door Burnet gelegd; latere immunologen stonden voor de taak de stukjes op de juiste plaats te leggen. Jerne beschreef dit verschil tussen Burnets bijdrage en die van latere immunologen tijdens de zeventigste verjaardag van Burnet in 1969 als volgt: 
'I imagine that in the year 2019, two elderly gentlemen that are at present sitting in this audience, will be discussing a newly published paper on a curious anomaly in the immune system of the penguin. One of them will say: now that we all know that immunology is completely solved, it would be interesting, in retrospect, to determine the date at which this occured. And the other will reply: in principle, immunology was solved in 1957 when Burnet published his Clonal Selection Theory of Acquired Immunity. ${ }^{3}$

Deze dialoog kon Jerne natuurlijk pas verzimnen nadat Burnets darwinistische aanlegtheorie de instructietheorie had overwonnen. In 1969 was voor velen duidelijk geworden dat de aanlegtheorie superieur was nadat deze theorie talrijke successen had geboekt terwijl de instructietheorie in een steeds dieper dal was beland. In de eerste jaren na 1957 waren de kaarten echter nog niet geschud.

Burnets ideeën waren in eerste instantie buitengewoon omstreden in de immunologische gemeenschap en velen lieten zich de eerste jaren na de geboorte van de klonale selectietheorie niet overtuigen. In zijn rede in 1959 merkte de Nederlandse immunoloog J.J. van Loghem op dat Burnets theorie een 'revolutionaire opvatting' was maar dat het onwaarschijnlijk was dat de theorie de verworven immuniteit 'tegen vele tienduizenden verschillende antigenen' kon verklaren. ${ }^{4}$ Deze kritiek was typerend voor de reactie van met name chemici en werd in $1966 \mathrm{nog}$ eens door W.C. Boyd herhaald: 'like Haurowitz, I find "it difficult to believe that the body should contain preformed antibodies against azophenylarsonate, azophenyltrimethylammonium ions, and other artefacts of the chemical laboratory". ${ }^{5}$ Chemici vonden Burnets aanlegtheorie veel te speculatief en voerden telkens empirische argumenten aan tegen de theorie. $\mathrm{Zij}$ legden de nadruk op het feit dat organismen tegen de meest uiteenlopende chemische stoffen antilichamen kunnen vormen en vonden het daarom onvoorstelbaar dat organismen deze stoffen door middel van een genetisch gereguleerd mechanisme kunnen herkennen. Omgekeerd accepteerden met name biologisch georiënteerde onderzoekers zoals Jerne Burnets aanlegtheorie van meet af aan op theoretische gronden. Zij wezen op de eenvoud, de elegantie en de verklarende kracht van Burnets aanlegtheorie en waren niet onder de indruk van de empirische argumenten die chemici ter verdediging van de instructietheorie aanvoerden.

De discussies over Burnets klonale selectietheorie tussen chemici en biologisch georiënteerde onderzoekers zijn nu een historisch curiosum: voor de huidige immunologie nauwelijks interessant omdat Burnets aanlegtheorie de chemische instructietheorie heeft overwonnen. Dat de 
ideeën van Burnet toendertijd omstreden waren is men vermoedelijk binnen de huidige immunologische gemeenschap allang vergeten. In moderne immunologische handboeken worden die discussies niet meer vermeld omdat zij achterhaald zijn. Vanuit een wetenschapstheoretisch oogpunt zijn de discussies echter wel interessant. Het meest opvallende aan de discussies is de koppeling tussen een inhoudelijke positie in het aanleg-omgeving vraagstuk en een methodologische benaderingswijze. De verdedigers van Burnets aanlegtheorie kozen voor een theoretischdeductieve aanpak, terwijl instructietheoretici een meer empirisch-inductieve aanpak voorstonden. Is dit een toevallige koppeling, of is hier sprake van een systematisch verband? Anders geformuleerd: staat een inhoudelijk standpunt in het aanleg-omgeving vraagstuk los van een methodologische benadering of zijn er bepaalde affiniteiten tussen een inhoudelijke en een methodologische positie?

\section{2}

\section{De Zoeklichttheorie en de Emmertheorie}

De tegenstelling tussen de klonale selectietheorie en de instructietheorie is een tegenstelling tussen twee strijdige perspectieven: aanleg versus omgeving. De klonale selectietheorie verklaart de specificiteit van de immunologische reactie met behulp van een evolutionair aanlegmechanisme; de instructietheorie met behulp van een leermechanisme. Deze tegenstelling tussen aanleg en omgeving vinden we ook in andere gebieden in de levenswetenschappen, vooral wanneer het begrip 'specificiteit' in het geding is. ${ }^{6}$ Specificiteit duidt in de levenswetenschappen op de unieke relatie tussen een agens en zijn effect. De specificiteit van de interactie tussen een antigeen en een antilichaam is hier een voorbeeld van. Andere voorbeelden zijn de relatie tussen een enzym en de stof waarop het inwerkt, het zogenaamde enzymsubstraat, of de relatie tussen een prikkel en een (ongeconditioneerde) response en de relatie tussen een 'releasing factor' en het 'innate releasing mechanism'. Deze laatste relatie slaat op het fenomeen dat een specifieke prikkel uit de omgeving een soortspecifiek gedragspatroon oproept.

In de theorievorming ten aanzien van de specificiteit van dergelijke reacties hebben omgevingstheorieën vaak tegenover aanlegtheorieën gestaan. Ook hier kan de immunologie als voorbeeld dienen: de specificiteit van de immunologische reactie werd eerst in termen van een omgevingstheorie verklaard en later in termen van een aanlegtheorie. Deze overgang vinden we ook in andere gebieden van de levenswetenschappen. Zo hebben instructietheorieën over metabole processen in 
deze eeuw alle het onderspit gedolven. De weerstand die bacteriën tegen antibacteriële stoffen opbouwen werd eerst gezien als een door de omgeving geinstrueerde aanpassing, totdat onder anderen Luria en Delbrück met hun interferentie-experiment aantoonden dat deze aanpassing ontstaat door selectie op al bestaande genen. Monod c.s. ontzenuwden later de (omgevings-) theorie dat bacteriën zich aan een bepaalde omgeving kunnen aanpassen door de (door de omgeving gestimuleerde) vorming van adaptieve enzymen. Deze enzymen werden gevormd door - alweer - selectie op al bestaande genen.

Hoewel er natuurlijk verschillen zijn tussen deze gevallen, herkennen we steeds de tegenstelling tussen een aanlegtheorie en een omgevingstheorie. Waaruit bestaat de kern van deze tegenstelling? Wat rechtvaardigt de stelling dat hier kan worden gesproken over een tegenstelling tussen aanleg en omgeving? Voor een antwoord op deze vragen kunnen we te rade gaan bij K.R. Popper. ${ }^{7}$

Volgens Popper bestaan er structurele gelijkenissen tussen de manier waarop fenomenen door aanlegtheorieën en omgevingstheorieën worden verklaard. Zo werd in alle drie omgevingstheorieën het ontstaan van de specificiteit verklaard uit instructie door herhaling: indien een organisme regelmatig in contact komt met een agens uit de omgeving, dan 'leert' het organisme na verloop van tijd het agens 'herkennen' zodat het hiermee kan interacteren. Omgekeerd werd in alle drie aanlegtheorieën de specificiteit van de reactie verklaard door een selectiemechanisme. Tijdens de evolutie is door trial and error-eliminatie het 'vermogen' ontstaan om te interacteren met het specifieke agens.

Het ontstaan van immuniteit, het ontstaan van de weerstand van bacteriën tegen antibacteriële stoffen en de vorming van adaptieve enzymen, kunnen alle analoog worden geïnterpreteerd naar het model van menselijke leerprocessen. Het zijn analogie-redeneringen met theorieën over de manier waarop mensen kennis verkrijgen over de ongeving . De ware tegenstelling tussen aanleg en omgeving wordt volgens Popper dan ook gevormd door de tegenstelling tussen twee theoretische perspectieven op de wijze waarop kennis wordt verkregen over de omgeving, die Popper respectievelijk de Emmertheorie en de Zoeklichttheorie van de geest heeft genoemd.

Volgens de Emmertheorie is de geest leeg bij de geboorte. Na de geboorte wordt de geest langzamerhand gevuld met informatie die via de zintuigen naar binnen stroomt. Uit die informatie wordt kennis over de omgeving opgebouwd door accumulatie van ervaringen. Zintuiglijke ervaringen zijn met andere woorden de bouwstenen voor algemene inzichten die via associatie van die bouwstenen tot stand komen. Ware kennis kan worden verkregen door onbevooroordeeld waar te nemen; 
fouten in de kennis zijn volgens de Emmertheorie te wijten aan de onzorgvuldige verwerking van zintuiglijke informatie.

Volgens de Zoeklichttheorie daarentegen bezit de geest van nature al bepaalde disposities en vermogens. Door rijping zullen die disposities en vermogens tot ontwikkeling komen. Kentheoretisch betekent dit dat de geest is uitgerust met structuren die minstens de aard van de kennis vormen of - in de sterkste vorm - al kennis bevatten. In dat laatste geval kan waarneming alleen een 'trigger' zijn die al aanwezige kennis vrijmaakt.

De Emmertheorie en de Zoeklichttheorie kunnen worden gezien als twee ideaaltypische opvattingen over de wijze waarop kennis wordt vergaard. In de levenswetenschappen vinden we volgens Popper transformaties van deze twee 'ideaaltypische' opvattingen die structurele gelijkenissen vertonen met deze twee tegenstrijdige perspectieven.

De empiristische associatiepsychologie en de rationalistische vermogenspsychologie zijn hier een eerste voorbeeld van $^{8}$ De associatiepsychologie gaat ervan uit dat zintuiglijke impressies de oorsprong vormen voor ideeên en voorstellingen. De primaire inhoud van het bewustzijn bestaat uit deze impressies, waaruit door associatiemechanismen ideeën en voorstellingen worden opgebouwd. De ontstaanswijze van complexe bewustzijnsinhouden wordt via deze associatiemechanismen verklaard. Zo zou uit warmte en licht, die te herleiden zijn tot de zintuiglijke sensaties voelen en zien, door associatiemechanismen het begrip 'vuur' worden gevormd. De verklaring van de ontstaanswijze van deze complexe bewustzijnsinhouden wordt geleverd door de wet van de contiguiteit: wanneer gewaarwording A vaak samengaat met gewaarwording B, dan zal de voorstelling a de voorstelling b, die bij B behoort, uiteindelijk oproepen. Problematisch voor de associatiepsychologie is de vraag waardoor gevormde associaties bij elkaar worden gehouden. Hoe kan de organische eenheid van het bewustzijn worden verklaard en hoe kan men dat empirisch onderzoeken? Soortgelijke problemen zouden in de twintigste eeuw aan behavioristische psychologen worden voorgelegd. ${ }^{9}$

In de rationalistische vermogenspsychologie veronderstelt men dat de geest al van nature over een aantal vermogens beschikt, zoals het vermogen tot redeneren of voorstellen. Uit een beperkt aantal grondvormen kunnen alle vermogens worden afgeleid. Deze aangeboren vermogens zijn constitutief voor de psychologische processen waarvoor zij staan, dat wil zeggen dat met een term als 'redeneervermogen' niet alleen het redeneerproces wordt aangeduid, maar ook de 'oorzaak' van die processen wordt beschreven. Problematisch voor de vermogenspsychologie is het feit dat het bestaan van vermogens niet onafhankelijk 
toetsbaar is. Het bestaan van vermogens kan alleen worden vastgesteld aan de hand wan dezelfde feiten die de aanleiding waren om hun bestaan te veronderstellen. De psycholoog Külpe beschreef dit probleem als volgt: 'Das ist ungefähr so, wie wenn man die Nässe der Strasse nicht durch den Regen, sondern durch ihre Fähigkeit, nass zu werden, erklären wollte. Als Erklärung wird eben dieser Vermögensbegriff, weil er auf alle Wirklichkeiten in derselben Weise angewandt werden kann, nichts leisten, denn er kann der Besonderkeit der zu erklärenden Tatsachen in dieser Form nicht gerecht werden, weil er nicht zwischen dispositionellen und auslösenden Bedingungen einer Erscheinung unterscheidet ${ }^{*}{ }^{10}$ Dezelfde bezwaren zouden in de jaren twintig van deze eeuw tegen de instinctpsychologie worden ingebracht. ${ }^{11}$

Een tweede transformatie van de Emmertheorie en de Zoeklichttheorie vinden we in de embryologie, waar de epigenetische en de preformationistische theorie lang tegenover elkaar stonden. ${ }^{12}$ In de zeventiende eeuwse (empiristische) epigenetische theorie stelde men dat alle organismen uit het ei ontstonden. Het embryo begon als een homogene massa waaruit geleidelijk de verschillende organen groeiden. De mannelijke zaadcel speelde in de epigenetische theorie een ondergeschikte rol. Volgens het (rationalistische) preformationisme was het organisme van meet af aan al gevormd en groeide het tijdens de ontwikkeling alleen maar. Sommigen dachten dan ook dat zaadcellen 'gepreformeerdex embryo's bevatten; het ei was volgens hen slechts voedsel voor de in de zaadcel aanwezige homunculus.

Een derde overgang van een Emmertheorie naar een Zoeklichttheorie vinden we in de evolutietheorieën van Lamarck en Darwin. Volgens de lamarckianistische evolutietheorie ontstaat de reeks steeds gecompliceerder wordende organismen onder invloed van twee mechanismen: de levenskracht die de organisatie van het leven op een steeds complexer niveau brengt en de omgeving die zorgt voor de differentiatie van de soorten. Omdat organismen zich aanpassen bij veranderende omstandigheden en sommige functies meer gebruiken dan andere, zullen die functies zich daardoor sterker ontwikkelen. Wanneer zulke eigenschappen overlevingswaarde hebben, worden zij volgens Lamarck erfelijk en kunnen ze aan nakomelingen worden overgedragen waardoor er verschillende soorten ontstaan. Het mechanisme waardoor eigenschappen die in een omgeving veelvuldig te pas komen erfelijk worden, lijkt op empiristische inductie: herhaling van observaties leidt tot algemene inzichten. Bovendien instrueert de omgeving in Lamarcks evolutietheorie het verloop van de evolutie zodat zijn theorie een typische representant is van de Emmertheorie. 
In Darwins evolutietheorie kan de ongeving de erfelijkheid en het evolutieproces niet veranderen. At random gegenereerde erfelijke variaties bevoordelen een organisme in de strijd om het bestaan, waardoor dat organisme meer kans krijgt zich woort te planten. Door natuurlijke selectie overleven via trial and error-mechanismen die organismen waarvan de erfelijke eigenschappen voordelig zijn in de omgeving waarin zij leven. Organismen met meer ongunstige eigenschappen zullen worden weggeselecteerd. Omdat een organisme al van nature (aangeboren) disposities heeft, past Darwins evolutietheorie bij de Zoeklichttheorie.

De tegenstellingen tussen de vermogenspsychologie versus de associatiepsychologie, preformatie versus epigenese en Darwins evolutietheorie versus die van Lamarck, kunnen analoog aan die tussen de Zoeklichttheorie en de Emmertheorie worden begrepen. In deze tegenstellingen zijn immers de basisschema's van Poppers tegenstelling getransformeerd. In figuur 1 staan een aantal kenmerken van deze tegenstelling weergegeven. Op voorhand kunnen we verwachten dat we nooit alle kenmerken in elk wetenschapsgebied terug zullen vinden. Wel kunnen we verwachten dat er structurele overeenkomsten zijjn tussen de verschillende aanlegtheorieën en de verschillende omgevingstheorieën, die we kunnen opmaken uit de wijze waarop onderzoekers problemen percipiëren, uit het gebruik van metaforen en analogieën en de manier waarop aanlegdenkers en omgevingsdenkers argumenteren in debatten.

Figuur 1

\section{Aanleg}

1. Aangeboren vermogens of disposities

2. Rijpingsprincipe

3. Organisme moeilijk veranderbaar

4. Selectie door trial and error elimination

5. Prikkels zijn triggers
Omgeving

1. Omgeving vormt eigenschappen en functies

2. Associatieprincipe

3. Organisme kneedbaar

4. Instructie door herhaling

5. prikkels zijn vormende stimuli 


\section{3}

\section{Deductivisme en inductivisme}

Poppers tegenstelling tussen de Zoeklichttheorie en de Emmertheorie van de geest is niet alleen een prototype voor de tegenstelling tussen aanleg en omgeving in de levenswetenschappen, maar is ook karakteristiek voor een filosofische tegenstelling. Op het vlak van de methodologie worden traditioneel twee opvattingen over de rechtvaardiging van kennis tegenover elkaar geplaatst: de deductief-rationalistische en de inductief-empiristische opvatting. Volgens de eerste kan men tot kennis komen wanneer men uitgaat van onbetwijfelbare principes, waaruit deductief verklaringen zijn af te leiden voor verschijnselen. Volgens de tweede opvatting ligt het fundament voor kennis in de ervaringswereld. Zintuiglijke ervaringen vormen de bouwstenen voor algemene inzichten die via inductie tot ontwikkeling worden gebracht.

Deze tegenstelling vinden we niet alleen in het werk van filosofen, maar ook in het werk van vakwetenschappers wanneer zij de 'wetenschappelijke methode' uiteenzetten. Volgens Konrad Lorenz is het:

'an inviolable law of inductive natural science that it has to begin with pure observation, totally devoid of any preconceived theory and even working hypothesis., 13

Deze inductieve methode is volgens Niko Tinbergen typerend voor de natuurwetenschappen:

'they all try to learn the causal relations and interrelations underlying the complicated phenomena known by direct observation., ${ }^{14}$

Tegenover deze uitspraken van de ethologen Lorenz en Tinbergen staan uitspraken van deductivisten die juist benadrukken dat waarnemingen niet het startpunt voor kenniswerwerving vormen. Sydney Brenner beschreef het onderzoek naar onder meer de genetische code binnen de moleculaire biologie als volgt:

"There was a culture - well a cult, almost - that became typical of molecular biology. What became prized was ingenuity.... An important thing about the best molecular biology would be those papers which, although they are experimentally intricate, nevertheless do things in such way that the kind of deduction about what is inside the animal, organism, is unique. And of course, the simpler methods used, the more highly prized. ... And I think that the cult got founded around 
these ideas of how to solve the code without even opening the black box.... I mean, Gamow had the idea you could do it without doing anything. But I mean, we realized you had to do some experiments." ${ }^{15}$

Linus Pauling, de vermaarde theoretisch chemicus, heeft zich een tijdlang beziggehouden met de immunologische problematiek. Hij ontwikkelde deductief een immunologische theorie in samenspraak met de immunoloog Landsteiner. Tijdens de gesprekken met Landsteiner merkte Pauling dat Landsteiners methodologische anpak verschilde van de zijne:

'At that time I found that Landsteiner and I had a very much different approach to science: Landsteiner would ask, 'what do the experimentally observations force us to believe about the nature of the world?' and I would ask, 'what is the most simple, general, and intellectually satisfying picture of the world that encompasses these observations and is not incompatible with them?' I think my attitude can be described as essentially that of the theoretical physicist. ${ }^{16}$

Dergelijke uitspraken laten zien dat de twee traditionele opvattingen over de rechtvaardiging van de kennis, de deductief-rationalistische en de inductief-empiristische, een rol spelen in de manier waarop onderzoekers hun praktijk beschrijven. Wetenschappers verwijzen naar methodologieën wanneer zij hun benadering willen onderscheiden van die van anderen. Dit roept de vraag op of deze twee methodologische posities daadwerkelijk een rol spelen in de onderzoekspraktijk. Zijn de rechtvaardigingspraktijken $z 6$ gestructureerd zoals op grond van de Poppers tegenstelling kan worden verwacht? Kan de wijze waarop kennis wordt geëvalueerd in termen van deze tegenstelling worden beschreven? Deze vragen naar de feitelijke rol van methodölogieën in de onderzoekspraktijk zullen in deze studie nog uitvoerig aan de orde komen.

Poppers Zoeklichttheorie en Emmertheorie kunnen worden gebruikt om zowel inhoudelijk-theoretische posities in de levenswetenschappen als methodologische posities te karakteriseren. Welke verbanden kunnen we verwachten tussen inhoudelijke en methodologische posities? Gezien de structurele overeenkomsten tussen de basisschema's van inhoudelijke en methodologische posities, liggen twee combinaties voor de hand: die tussen aanlegtheorieën en de deductieve methodologie, en die tussen omgevingstheorieën en de inductieve methodologie. Wie veronderstelt dat organismen bijvoorbeeld gedragingen leren, doordat ze herhaaldelijk bepaalde ervaringen opdoen, zal 
eerder van mening zujn dat kennis is gebaseerd op ervaring, dan dat kennis een produkt is van het verstand. Omgekeerd zal een aanlegdenker, die meent dat gedragingen aangeboren zijn en in de evolutie zijn uitgeselecteerd, niet snel van mening zijn dat kennis louter gebaseerd is op ervaringen, maar eerder verdedigen dat ook kennis tot stand komt door selectie op verzonnen ideeen. Het is met andere woorden aannemelijk dat; door de structurele gelijkenissen tussen de basisschema's, er affiniteiten zijn tussen aanlegtheorieën en de deductieve methodollogie, en tussen omgevingstheorieèn en de inductieve methodologie. Wanneer onderzoekers ergens een omgevingstheorie veronderstellen, zullen zij dat op meerdere plaatsen doen. Van bijvoorbeeld behavioristen, die van mening zijn dat organismen gedragingen leren, valt niet te verwachten dat zij daarnaast het preformationisme verdedigen. Zo'n verband geldt niet alleen voor de verschillende omgevingstheorieën onderling, maar ook voor de relatie tussen de omgevingstheorieën en de inductieve methodologie (en tussen aanlegtheorieën en de deductieve methodologie).

Deze relatie tussen inhoudelijke en methodologische posities wordt ook gelegd door onderzoekers in de levenswetenschappen zelf.

Een typisch voorbeeld levert Fisher, die achteraf bezien als de 'vader' van de sociobiologie kan worden beschouwd. Hij heeft een verklaring gegeven voor een probleem waarover Darwin zich al had gebogen: waarom is de sexe-verhouding 1:1? In de eerste editie van The Descent. of Man verklaarde Darwin de 1:1 verhouding door te stellen dat deze verhouding voordelig was voor de soort, maar in de tweede editie van dit boek trok hij zijn verklaring terug: 'I formerly thought that when a tendency to produce the two sexes in equal numbers was advantageous to the species, it would follow from natural selection, but I now see that the whole problem is so intricate that it is safer to leave its solution to the future'. ${ }^{17}$ De wiskundige Fisher vond als eerste een bevredigende oplossing voor Darwins probleem. ${ }^{18}$ Uitgangspunt in zijn verklaring is het simpele gegeven dat iedere zygote uit eên eicel en één spermacel ontstaat. Dat betekent dat de bijdrage van de mannetjes en de wijfjes aan de volgende generatie even groot is, en dus is hun 'fitness' even hoog. Stel nu dat er in een populatie relatief veel vrouwtjes zijn. Dan zou bet volgens Fisher voor ouders lonen om veel zonen te produceren omdat die zonen dan meer kinderen zouden kunnen krijgen. Dus zal het gen dat de ouders 'aanzet' tot de productie van meer zonen toenemen in de populatie. Met dezelfde argumentatie kan men beredeneren waarom het voor ouders loont om meer dochters te produceren wanneer er relatief veel mannetjes in de populatie zijn. Bij gevolg zal in een populatie met teveel individuen van é́n sexe selectie ten voordele van de 
productie van de andere werken. Alleen de 1:1 sexe-verhouding is evolutionair stabiel.

Fishers gencentrische, theoretische verklaring van de stabiliteit van de sexe-verhouding is een typisch produkt van deductief onderzoek. Met behulp van een gedachtenexperiment toont hij aan dat andere sexe-verhoudingen dan de 1:1 verhouding niet evolutionair stabiel zijn. De feitelijke situatie wordt door Fisher verklaard als éen van de theoretisch mogelijke situaties.

Het meest opvallende aan Fishers verklaring is de koppeling tussen een (gencentrische) aanlegtheorie en een deductieve benadering. Deze koppeling was in de levenswetenschappen niet gebruikelijk en Fisher heeft in het voorwoord tot de The General Theory of Natural Selection zelf een verklaring gegeven voor zijn uitzonderingspositie. ${ }^{19}$ Fisher onderscheidt in dit voorwoord twee cognitieve stijlen of, zoals Fisher het noemt, 'types of mind': een empirische (of klassiek-biologische) stijl en een theoretische (of wiskundige) stijl. De verschillen tussen deze twee stijlen brengt Fisher in verband met de verschillen tussen een biologische en een wiskundige opleiding. Biologen komen volgens hem al vroeg tijdens hun studie in aanraking met de complexiteit van de natuur, wanneer zij tijdens practica dieren en planten classificeren, ontleden, etcetera. Wiskundestudenten zijn op dat moment louter bezig met abstracties, zoals punten, lijnen of vergelijkingen. Vanwege deze verschillen zijn wiskundig geschoolde onderzoekers volgens Fisher eerder geneigd problemen deductief te onderzoeken, door de feitelijke situatie op te vatten als éen van de theoretisch mogelijke situaties die daarom verklaard moet worden. Dit in tegenstelling tot de biologisch geschoolde onderzoeker:

"No practical biologist interested in sexual reproduction would led to work out the detailed consequences experienced by organisms having three or more sexes, yet what else should he do if he wishes to understand why the sexes are, in fact, always two? 20

Er is volgens Fisher een verband tussen een inhoudelijk theoretische positie in het aanleg-omgeving vraagstuk en een methodologische benadering. Theoretisch (of wiskundig) georiënteerde onderzoekers zullen eerder een abstracte aanlegtheorie verzinnen en empirisch opgeleide onderzoekers eerder een ongevingstheorie. Net als in het geval van de immunologie, constateert Fisher dat er affiniteiten zijn tussen enerzijds een aanlegtheorie en een deductieve methodologie en anderzijds tussen een omgevingstheorie en een inductieve benadering. 
Fishers stellingname krijgt meer gewicht wanneer we de sociobiologie, die voortbouwt op onder meer het werk van Fisher, erbij betrekken. De sociobiologie wordt gekenmerkt door een gencentrische aanlegtheorie en een deductieve onderzoekstijl. Dit kan worden uitgewerkt aan de hand van een van de bekendste sociobiologische verklaringen: de verklaring van de noodzakelijke verschillen tussen mannetjes en wijfjes bij de ouderlijke zorg. Uitgangspunt in deze verklaring is dat beide seksen erop gericht zijn tegen zo weinig mogelijk kosten zoveel mogelijk nakomelingen te produceren. De vrouwtjes zijn in dit geval 'benadeeld', omdat zij het embryo dragen en daardoor meer moeten investeren dan de mannetjes. De mannetjes daarentegen zouden hun reproductief succes kunnen vergroten door zoveel mogelijk vrouwtjes te bevruchten. Voor de mannetjes zijn cle vrouwtjes dus de beperkende factor en daarom kunnen we verwachten dat er competitie zal zijn tussen de mannetjes om de vrouwtjes, temeer daar een eigenschap zoals 'kracht', die mannetjes helpen meer vrouwtjes te bevruchten, hun genen disproportioneel in de populatie zal doen verspreiden. Deze verklaring blijkt goed met de feiten in overeenstemming, ook in die gevallen waar de mannetjes meer investeren in het nageslacht: daar vechten de vrouwtjes om de mannetjes.

Binnen de sociobiologische onderzoekstraditie is deze verklaring verder gearticuleerd door Dawkins. ${ }^{21} \mathrm{Hij}$ heeft aangetoond dat er voor de 'benadeelde' sekse in ieder geval twee evolutionair stabiele strategieën zijn om hun reproduktief succes verder te maximaliseren: de Huiselijk Geluk strategie en de Sterke Man strategie. In de eerste strategie kiest het vrouwtje voor een meer timide man die meer geneigd is om haar substantieel te helpen bij de verzorging van het kroost; in de tweede strategie kiest zij een man met 'goede' genen met het oog op haar nakomelingen (die deze genen zullen erven), maar loopt zij het risico dat de Sterke Man ontrouw is.

Net zoals Burnets speculatieve aanlegtheorie het doelwit is geweest van kritiek, zo werd de sociobiologie bekritiseerd door onder andere culturele anthropologen ${ }^{22}$ Uiteraard legden de kritici de nadruk op het belang van omgevingsfactoren: (menselijk) gedrag werd niet geregeerd door genen maar werd volgens de kritici grotendeels bepaald door cultuur. Opvallend was dat deze kritiek ook in dit geval gekoppeld was aan een nadruk op feiten, dat wil zeggen: aan een empiristische benaderingswijze. Wie voldoende oog had voor de historische en culturele feiten, zou de onjuistheid van de sociobiologische aanlegtheorie snel inzien. Terwijl sociobiologen zich juist niet bekommerden om details en alleen de door de theorie relevant gemaakte feiten interessant vonden, benadrukten omgevingsdenkers juist de complexiteit van de wereld: de 
historische en culturele diversiteit was voor hun een belangrijke reden om de sociobiologie niet au serieux te nemen. Wie de feiten niet onder ogen wilde zien, zo redeneerden tegenstanders van de sociobiologie, moest wel ideologisch bezig zijn.

Deze laatste kritiek vinden we zelfs terug in het debat tussen de sociobioloog Wilson en de populatiegeneticus (maar tegenstander wan de sociobiologie én omgevingsdenker) Lewontin. ${ }^{23}$ Lewontin legde in dat debat de nadruk op het belang van een voorzichtige, empirische aanpak omdat de wereld complex was. Daarom kritiseerde hij de sterke vereenvoudigingen van de sociobiologen. 'God is in the details', volgens Lewontin, dat wil zeggen dat goede wetenschap gebaseerd is op zorgvuldig vastgestelde feiten. ${ }^{24}$ Modellenbouw, zoals die werd bedreven door sociobiologen, was volgens Lewontin geen serieuze wetenschap omdat daardoor de complexiteit van de wereld over het hoofd werd gezien. Zo maakte Lewontin bezwaren tegen de 'bean-bag-genetics' van de sociobiologen omdat interactieprocessen tussen genen werden genegeerd. De sociobiologie was daarom volgens Lewontin een voorbeeld van 'slechte' wetenschap en hij wilde met zijn kritiek aantonen dat de sociobiologische ideeën voortkwamen uit de 'verkeerde' politieke opvattingen. Om dàt aan te tonen, probeerde Lewontin eerst de 'fouten' in de sociobiologie op te sporen om vervolgens aan te kunnen tonen hoe die 'fouten' voortkwamen uit de 'verkeerde' politieke veronderstellingen.

Tegenover Lewontins nadruk op voorzichtigheid legde Wilson in het debat juist de nadruk op het belang van vereenvoudigingen, zelfs wanneer dat 'bean-bag-genetics' impliceerde. Volgens Wilson was Lewontins benadering 'too safe' en 'hugging the coast'. ${ }^{25} \mathrm{Hij}$ werkte bij voorkeur in wetenschapsgebieden waar ruimte was voor 'creative but risky' benaderingen, zoals de oecologie of sociaal gedrag. Lewontins wetenschapsgebied, de populatiegenetica, was volgens Wilson te 'gestructureerd' en 'uitgedroogd'. Lewontins bezwaren tegen sterke vereenvoudigingen en modellenbouw waren volgens Wilson niet ter zake, omdat modellen voorlopig voor 'waar' werden aangenomen en later verder verfijnd en gearticuleerd konden worden. Het criterium voor goede wetenschap was voor Wilson de testbaarheid van theorieën.

De discussies tussen Lewontin en Wilson laten opnieuw zien dat er affiniteiten zijn tussen een inhoudelijke positie in het aanleg-omgeving vraagstuk en een methodologische benadering. Aanlegtheoretici geven eerder de voorkeur aan een deductieve aanpak, terwijl omgevingstheoretici eerder een empiristische benadering voorstaan.

Deze affiniteiten kunnen inzichtelijk worden gemaakt vanuit Poppers tegenstelling tussen de Zoeklichttheorie en de Emmertheorie. Volgens 
de Emmertheorie komt informatie van buttenaf in de geest en ontstaan door associatieprocessen algemene inzichten. Vertaald naar wetenschappelijk onderzoek betekent dit dat eerst de concrete stimuli uit de omgeving gelokaliseerd moeten worden. Welke omgevingsfactoren liggen ten grondslag aan algemene inzichten? Hoe beinvloeden deze concrete omgevingsfactoren het ontstaan van die inzichten? Antwoorden op dergelijke vragen kunnen worden verkregen door de omgeving precies te beschrijven en te classificeren; of door omgevingsfactoren experimenteel te manipuleren. Daardoor hebben omgevingsdenkers vaak een goed oog voor de diversiteit en de complexiteit van de wereld en zijn zij wars van gewaagde vereenvoudigingen. Omdat uiteindelijk de concrete omgevingsstimuli constitutief zijn voor algemene inzichten, zal in het wetenschappelijk onderzoek eerder de nadruk liggen op feiten en de complexiteit van de wereld. Hypotheses zullen dicht bij het concrete empirische onderzoeksmateriaal blijven; theorieên zullen slechts mondjesmaat en heel voorzichtig tot ontwikkeling worden gebracht.

Omgekeerd zullen aanlegtheoretici eerder deductief te werk gaan omdat de omgeving in de Zoeklichttheorie op het tweede plan staat. Die fungeert immers slechts als 'trigger' en is niet constitutief voor algemene inzichten. Uit concrete feiten kan moeilijk kennis worden verkregen over de aard van aanlegmechanismen en daarom zullen aanlegtheoretici eerder een gewaagde theorie ontwerpen over de wijze waarop aanlegmechanismen door selectieprocessen zijn ontstaan. Zo'n hypothetisch aanlegmechanisme was in het geval de sociobiologie een gencentrisch, speltheoretisch model. De theorieontwikkeling zal bepalen welke feiten met welke maat van precisie van belang zijn. Terwijl omgevingsdenkers eerder het tempo van theorieontwikkeling conditioneren naar de aanwas van waarnemingen en het verzamelen van feiten, ligt de zaak bij aanlegdenkers precies omgekeerd: de theorie bepaalt welke feiten met welke maat van precisie van belang zijn. Daarom zullen aanlegdenkers weinig waarde hechten aan de complexiteit en de diversiteit van de wereld en geen bezwaren maken tegen sterke vereenvoudigingen.

\section{4}

\section{Onderzoeksplan}

Uit Poppers tegenstelling tussen de Zoeklichttheorie en de Emmertheorie wordt een verband gesuggereerd tussen het aanleg-omgeving vraagstuk in de levenswetenschappen en methodologische benaderingen van dit vraagstuk. Dit verband vloeit voort uit de structurele over- 
eenkomsten tussen de twee basisschema's van Poppers tegenstelling: selectie door trial and error-eliminatie versus instructie door herhaling.

Wat bij Popper nog op de achtergrond bleef - de affiniteiten tussen inhoudelijke en methodologische posities - komt in deze studie centraal te staan. Popper heeft de nadruk gelegd op het belang van de methodologie bij analyses van ontwikkelingen in de wetenschap. De keuzes van onderzoekers voor theorieën zouden volgens hem tot stand moeten komen doordat onderzoekers theorieën evalueren aan de hand van methodologische regels. De voorkeur voor een inhoudelijke theorie behoort met andere woorden af te hangen van een methodologische evaluatie. Deze nadruk op de rol van de methodologie is in het geval van het aanleg-omgeving vraagstuk problematisch, omdat een methodologische voorkeur in dit geval gekoppeld is aan een inhoudelijke positie. De discussies tussen Lewontin en Wilson illustreren dit probleem: een methodologische keuze in dat debat impliceert tevens een inhoudelijke voorkeur. Ook de ideeën van Popper zelf zijn illustratief: hij heeft op epistemologische gronden beargumenteerd waarom een deductivistische methodologie te verkiezen valt boven een inductivistische. Door de affiniteiten tussen inhoudelijke en methodologische posities, heeft Popper daarom - impliciet dan wel expliciet - een voorkeur voor aanlegtheorieën in de llevenswetenschappen. Zo heeft hij bijvoorbeeld de ethologische aanlegtheorie van Lorenz verdedigd tegenover behavioristische omgevingstheorieën, en heeft Popper de associatiepsychologie bekritiseerd. ${ }^{26}$ Gezien de affiniteiten tussen inhoudelijke en methodologische posities viel deze voorkeur ook te verwachten. Door deze affiniteiten kunnen we verwachten dat deductivisten een systematische voorkeur hebben voor aanlegtheorieën, en inductivisten voor omgevingstheorieën.

De relaties tussen inhoudelijke en methodologische posities zijn in het geval van het aanleg-omgeving vraagstuk problematisch, omdat er affiniteiten zijn tussen inhoudelijke en methodologische posities, zodat in dit specifieke geval deze relaties niet in één richting hoeven te worden geïnterpreteerd. In plaats van te stellen dat methodologische voorkeuren inhoudelijke repercussies hebben, volgt ook uit de gesignaleerde affiniteiten dat inhoudelijke voorkeuren consequenties hebben voor de methodologische positie. Kortom wanneer we de affiniteiten tussen inhoudelijke en methodologische posities centraal stellen, dan verandert de manier waarop we het aanleg-omgeving moet worden onderzocht. Voor Popper is het vraagstuk primair een methodologisch probleem en pas in tweede instantie een inhoudelijk vraagstuk met een historische dimensie. De manier waarop Popper het aanleg-omgeving analyseert is daardoor sterk gekleurd door zijn methodologische over- 
twigingen. Juist woor analyses van inhoudelijke ontwikkelingen rondom het aanleg-omgeving vraagstuk in de levenswetenschappen is dit een beperkte strategie, waarvan op voorhand kan worden gezegd dat die op ten minste twee terreinen tot simplificaties leidt. In de eerste plaats op het terrein van de methodologie. Popper heeft op epistemologische gronden een voorkeur voor de deductieve methodologie. Deze voorkeur heeft verstrekkende consequenties voor de beoordeling van de in het onderzoek gangbare methodologische praktijken. De gevolgen van Poppers opvatting zijn hierboven aan de orde geweest: Poppers wetenschapstheorie leidt maar al te snel tot een indeling in 'goede' en 'foute' methodologieën, waardoor de 'foute' methodologie als overgeleverde fictie moet worden verklaard. In de tweede plaats heeft de nadruk op het primaat van de methodologie tot gevolg dat Popper ook snel een oordeel velt over inhoudelijke theorieën. Naar aanleiding van Poppers wetenschapstheorie rijst de vraag of a priori een positief dan wel negatief oordeel kan worden geveld over respectievelijk aanleg- en omgevingstheorieën. Omdat het aanleg-omgeving vraagstuk ogenschijnlijk wordt gekenmerkt door tegenstellingen, is de verleiding groot om de etiketten 'juist' of 'fout' ook toe te kennen aan inhoudelijke posities. Een vluchtige blik op de geschiedenis van aanleg-omgeving vraagstuk lijkt hier bovendien alle aanleiding toe te geven. Aanleg en omgeving komen daaruit naar voren als twee strijdige perspectieven waartussen wij lijken te moeten kiezen. Zoals het immunologie ging om de strijd tussen de instructietheorie en de klonale selectietheorie, zo lijkt in het algemeen te gaan om de strijd tussen aanlegtheorieën en omgevingstheorieën. 'Aanleg' en 'omgeving' lijken tegenover elkaar te staan waardoor een symbiose tussen deze twee perspectieven niet aannemelijk lijkt. Wanneer we niet Poppers, maar Kuhns wetenschapstheorie als instrument voor nadere analyse nemen, dan kunnen we hieraan toevoegen toe dat deze twee perspectieven incommensurabel zijn. Dit leidt tot een pessimistische visie op de tegenstelling tussen 'aanleg' en 'omgeving', waaruit louter controversen tussen vertegenwoordigers van de twee perspectieven kunnen worden afgeleid. Deze stellingname kan bovendien worden gestaafd onder verwijzing naar de steeds terugkerende debatten rondom het aanleg-omgeving vraagstuk. Of het nu gaat om de immunologie, de sociobiologie of het IQ-onderzoek, telkens zien we dat het aanleg-omgeving vraagstuk partijen verdeelt. Of deze voorstelling van zaken recht doet aan de feitelijke gang van zaken rond het aanleg-omgeving vraagstuk, staat dan als probleem niet of nauwelijks meer ter discussie.

Wanneer de affiniteiten tussen inhoudelijke en methodologische posities centraal staan, dan dient het primaat van de methodologische 
analyse vervangen te worden door een meer 'symmetrische' analyse van zowel inhoudelijke en methodologische standpunten. Uit de affiniteiten kan immers ook worden afgeleid dat een voorkeur voor cen methodologie wordt ingegeven door een inhoudelijke positie. We kunnen, met andere woorden, niet het primaat leggen bij de methodologie of de inhoudelijke positie omdat die juist samenhangen. Daaron zal in deze studie zowel een historisch-inhoudelijke als een methodologische analyse worden gegeven van het aanleg-ongeving vraagstuk. Daarvoor zullen een drietal onderwerpen onder de loep worden genomen die slecht te rijmen zijn met Poppers oorspronkelijke tegenstelling.

In de eerste plaats is Poppers filosofische tegenstelling tussen de Zoeklichttheorie en de Emmertheorie volgens sommigen op bepaalde punten achterhaald. Deze kritiek valt in twee punten uiteen. Ten eerste veronderstelt Popper een tegenstelling tussen de (juiste) deductivistische methodologie en de (foute) inductivistische methodologie. Omdat de inductivistische methodologie epistemollogisch niet houdbaar is, verwacht Popper dat deze methodologie in de onderzoekspraktijk geen enkele rol van betekenis speelt. Met name historici hebben beargumenteerd dat Poppers voorstelling van zaken op dit laatste punt onjuist is. In de wetenschappelijke praktijk kan volgens hen naast een deductieve methodologie een meer inductieve stijl worden onderscheiden. Deze kritiek van historici op Popper zal in hoofdstuk 2 aan de orde komen, waarbij de vraag centraal staat of inductief onderzoek inderdaad methodologisch een ander karakter heelt dan deductief problemen oplossen. Ten tweede valt uit het werk van de latere Wittgenstein een ander argument af te leiden tegen Poppers Zoeklichttheorie. Volgens Poppers Zoeklichttheorie wordt elke waarneming verricht in het licht van een theorie en heeft elke uitspraak een theoretisch karakter. Wittgenstein heeft in zijn latere werk beargumenteerd dat deze gedachtengang niet juist is. Er zijn volgens. Wittgenstein uitspraken die noch een theoretisch karakter hebben, noch gefundeerd zijn in de ervaring - zoals de logisch empiristen dachten. Deze ideeën van Wittgenstein worden in hoofdstuk 4 uitgewerkt en gebruikt om Poppers tegenstelling tussen de Zoeklichttheorie en de Emmertheorie nader te analyseren.

In de tweede plaats is de tegenstelling tussen aanlegtheorieën en omgevingstheorieën volgens sommige onderzoekers in de levenswetenschappen op bepaalde punten achterhaald. $\mathrm{Zij}$ menen dat een symbiose tussen deze twee theorieën mogelijk is en wijzen op het feit dat in de loop van deze eeuw vruchtbare samenwerkingsverbanden zijn ontstaan tussen aanlegdenkers en omgevingsdenkers. Aanleg en omgeving staan volgens hen in een functionele relatie tot elkaar en daarom is de dichotomie tussen aanleg en omgeving onjuist. Het ligt voor de hand om 
eigenschappen van organismen toe te schrijven aan aanleg, wanneer die eigenschappen bij individuen weinig variatie vertonen zelfs indien die individuen in sterk verschillende omgevingen zijn opgegroeid. Deze veronderstelling is volgens hen echter onjuist. Evenzo is het volgens hen onjuist om eigenschappen, die grote variatie vertonen en al naar gelang de omgevingsinvloeden variëren, toe te schrijven aan omgevingsfactoren. Deze veronderstelling leidt namelijk tot de vraag in welke mate eigenschappen van organismen afhangen van genetische en omgevingsfactoren, en die vraag is volgens hen zinloos. De vraag is in de bekende woorden van Hebb even zinvol als de vraag naar welk deel wan de oppervlakte van een terrein kan worden toegeschreven aan de lengte, en welke deel aan de breedte. ${ }^{27}$ Omdat deze kritiek regelmatig wordt gehoord in kringen van onderzoekers die het gedrag van dieren onderzoeken, zal ik in hoofdstuk 3 een aantal ontwikkelingen die tot die opvattingen hebben geleid historisch onderzoeken. Daarvoor wordt het aanleg-omgeving vraagstuk onderzocht in een grensgebied tussen de ethologie en het behaviorisme. In de jaren vijftig en zestig hebben zich een tweetal interessante controversen voorgedaan rondom de vraag of bepaalde gedragspatronen aangeboren zijn of aangeleerd. Deze controversen zal ik in termen van Kuhns wetenschapstheorie analyseren en daarbij de vraag stellen of er inderdaad een nieuw perspectief is ontstaan waarin aanleg en omgeving zijn verenigd.

Tegen de achtergrond van deze controversen wordt in hoofdstuk 5 de opkomst van de sociobiologie onderzocht. Deze onderzoekstraditie wordt gekenmerkt door een extreme aanlegtheorie en de vraag rijst hoe de sociobiologie zich verhoudt tot de 'synthese' tussen aanleg en omgeving die eind jaren zestig ontstond. Ik zal betogen dat de extreme aanlegtheorie in de sociobiologie voortkomt uit de koppeling tussen een sterk deductieve benaderingswijze en het verklaren van de 'uiteindelijke oorzaken' voor gedrag. De consequenties van deze benadering van sociaal gedrag zullen vervolgens worden geanalyseerd door een recente controverse tussen sociobiologen en ethologen te onderzoeken.

In de derde plaats valt te vernemen dat de tegenstelling tussen de Zoeklichttheorie en de Emmertheorie te grof zou zijn om verschillen tussen de natuur-, levens- en socialle wetenschappen in kaart te brengen. Hoewel Poppers tegenstelling bruikbaar is om globale tegenstellingen in de verschillende wetenschapsgebieden in het vizier te krijgen, zou de tegenstelling subtiele verschillen niet in een scherp daglicht kunnen stellen: die blijven over- of onderbelicht. De tegenstelling tussen aanleg en omgeving in de grensgebieden tussen de chemie en de biologie bijvoorbeeld zou een ander karakter hebben dan die in het IQ-onderzoek, omdat in het laatste geval ook normatieve kwesties in het geding 
zijn. Dit probleem wordt in de hoofdstukken 6 en 7 nader onderzocht: In hoofdstuk 6 wordt de opkomst van de (biologische) klonale selectietheorie onderzocht tegen de achtergrond van de (chemische) instructietheorie. Hierbij staat de vraag centraal in hoeverre verschillen tussen de chemie en biologie consequenties hebben gehad voor de perceptie van het aanleg-omgeving probleem door chemici en biologen. In hoofdstuk 7 wordt onderzocht in hoeverre verschillen tussen de levenswetenschappen en de gedragswetenschappen consequenties hebben voor de manier waarop biologen, psychologen en sociologen omgaan met het aanleg-omgeving vraagstuk. Daarwoor zal ik het aanleg-omgeving vraagstuk in met name het intelligentie-onderzoek analyseren en vergelijken met ontwikkelingen in de humane ethologie en sociobiologie. 


\section{2 \\ Methodologische stijlen}

2.1

Inleiding

Filosofen zijn gewoon een onderscheid te maken tussen de theoretische, deductieve benadering en de empirische, inductieve benadering in de wetenschap. Deze tegenstelling is de methodologische vertaling van wat Popper omschrijft als respectievelijk de Zoeklichttheorie en de Emmertheorie van de geest. Volgens de eerste kan men tot ware kennis komen door deductief uit principes verklaringen af te leiden voor verschijnselen. Volgens de tweede dient men juist eerst concrete feiten te verzamelen om vervolgens via inductieve generalisaties algemene inzichten te kunnen formuleren. Deze methodologische tegenstelling vinden we ook in de onderzoekspraktijk. In historisch onderzoek is hierop al vaak gewezen. Kuhn ${ }^{1}$, bijvoorbeeld, onderscheidt vór 1800 twee tradities in de wetenschap: de mathematische of klassieke traditie, waartoe onder andere de mechanica en de astronomie behoorden, en de experimenterende of Baconiaanse traditie, waartoe onder meer de scheikunde wordt gerekend. Het onderzoek in de mathematische traditie was theoretisch; de uitgevoerde experimenten waren vaak gedachtenexperimenten. In de experimenterende traditie voerde men daadwerkelijk experimenten uit terwijl theoretiseren en gedachtenexperimenten werden veracht. Boon ${ }^{2}$ onderscheidt in zijn analyse van de ontdekking van de DNA-structuur eveneens twee stijlen: een gewaagde, deductieve stijl en een voorzichtige, inductieve stijl. Bij cleze ontdekking speelde de Röntgen-diffractie een belangrijke rol. De kristallografen gebruikten een inductieve benadering: zij probeerden aan de hand van patronen, verkregen met Röntgen-diffractie, terug te redeneren naar de driedimensionale structuur van het molecuul. In de deductieve benadering ging men uit van theoretische overwegingen en ontwikkelde men een driedimensionaal model van het molecuul dat al tijdens het opstellen werd getoetst aan de patronen verkregen met Röntgen-diffractie. De resultaten van het empirisch onderzoek gebruikte men in deze 
tweede benadering dus niet als uitgangspunten, maar als gegevens voor het bijstellen van het model totdat uiteindelijk het 'juiste' model was gevonden. Met deze deductieve benadering ontdekten Watson en Crick de structuur van het DNA. Het onderscheid tussen de inductieve en de deductieve stijl lijkt een algemeen verschijnsel in de wetenschap te zijn. Kuhn besluit zijn hoofdstuk zelfs met de suggestieve opmerking dat de kloof tussen beide wel eens blijvend kan zijn, 'rooted in the nature of the human mind'. ${ }^{3}$ Boon eindigt zijn artikel met een pleidooi voor methodologisch pluralisme, 'in verwachting dat elke methodologie, hoe arm of rijk zij ook moge zijn, in sommige situaties de groei van de wetenschap zal bevorderen'. Beide auteurs nemen op grond van empirisch onderzoek afscheid van de Popperiaanse these dat er slechts eén goede methodologische stijl is.

Wat zijn nu precies de methodologische verschillen tussen de inductieve en de deductieve stijl? Welke consequenties hebben deze verschillen voor de wijze waarop theorieën worden ontwikkeld en geëvalueerd? Een systematische uitwerking van de methodologische verschillen tussen de twee stijlen vormt de opgave van dit hoofdstuk.

In paragraaf 2.2 zal deze probleemstelling verder worden gespecificeerd. Daarvoor wordt eerst ingegaan op de wetenschapsfilosofie van Popper. Popper heeft beargumenteerd dat kennisgroei alleen mogelijk is met een deductieve stijl. Zijn wetenschapsfilosofie biedt geen ruimte voor methodologisch pluralisme, waardoor Popper elke ontwikkeling in de wetenschap kritisch-rationalistisch moet reconstrueren. Popper gaat uit van een eenheid van methode in de empirische wetenschappen en verwacht dat onderzoekers conform zijn deductieve methodologie theorieën ontwikkelen en testen. Deze positie heeft hem uiteraard kwetsbaar gemaakt voor historische kritiek. Hoewel Popperiaanse reconstructies van rechtvaardigingspraktijken in de 'hardere" wetenschappen succesvol zijn geweest, is de historische adequaatheid van Poppers methodologie voor 'zachtere' wetenschappen als de biologie in twijfel getrokken. Onderzoekers zouden volgens die kritiek niet alleen deductief te werk gaan, maar ook inductief theorieën ontwikkelen. Gezien zijn kritiek op het inductie-principe zijn er voor Popper echter geen redenen om deze 'afwijkingen' methodologisch te interpreteren, omdat de inductieve methode volgens hem in de wetenschap geen enkele rol speelt (par. 2.3). Dit aspect in zijn wetenschapstheoric maakt de theorie geschikt om het probleem van de twee methodologische stijlen historisch te onderzoeken. Aan de hand van de ontdekking van penicilline zal eerst worden beargumenteerd waarom Poppers stellingname, dat elke ontdekking deductivistisch kan worden gereconstrueerd, op historische gronden niet houdbaar is (par. 2.4). Nadat een alterna- 
tieve interpretatie wan deze ontdekking is gegeven, zal het hier geschetste probleem nader kunnen worden gepreciseerd (par, 2.5 en 2.6).

\section{2 \\ De deductieve stijl}

De tegenstelling tussen de Zoeklichttheorie en de Emmertheorie is een erfenis van de wetenschappelijke revolutie. Sinds de wetenschappelijke revolutie heeft de vraag naar de rechtvaardiging van wetenschappelijke kennis centraal gestaan in het wetenschapsfillosofisch onderzoek. In de klassieke tegenstelling tussen de Emmertheorie en de Zoeklichttheorie van de geest had het rechtvaardigingsprobleem betrekking op het fundament van empirische kennis. Ruwweg stonden twee filosofische posities tegenover elkaar: ofwel kennis was te funderen in zintuiglijke ervaring en kwam via inductie tot stand; ofwel kennis was te funderen in (aangeboren) principes waaruit men deductief kon 'afdalen' naar de wereld van de verschijnselen. ${ }^{5}$ Deze twee klassieke filosofische posities voor de rechtvaardiging van kennis werden in de 16e en $17 \mathrm{e}$ eeuw tevens gezien als methoden voor onderzoekers om kennis te verwerven. Dat laatste vinden we in deze eeuw niet meer terug in de tegenstelling tussen het logisch empirisme en Poppers kritisch rationalisme, omdat een onderscheid wordt gemaakt tussen de context of discovery en de context of justification. Volgens de logisch empiristen valt de vraag hoe onderzoekers theorieën ontwikkelen en bijstellen buiten het domein van het wetenschapsfilosofisch onderzoek. Dat dient volgens hen overgelaten te worden aan psychologen en sociologen en behoort tot de ontdekkingscontext. Een filosoof behoort volgens de logisch empiristen ontwikkelde kennis te analyseren en moet laten zien hoe die kennis te rechtvaardigen is. Popper maakt eveneens een onderscheid tussen de twee contexten, maar trekt een andere scheidslijn. Hoe onderzoekers tot theorieën of ideeën komen behoort volgens Popper tot de ontdekkingscontext, en in dit opzicht komen zijn opvattingen overeen met die van de logisch empiristen. Popper geeft echter een dynamischer invulling van de rechtvaardigingscontext. In de rechtvaardigingscontext gaat het bij Popper niet meer om een statische analyse van de wijze waarop kennis te rechtvaardigen is, maar om de vraag hoe in het onderzoeksproces de keuzes van onderzoekers voor theorieën te rechtvaardigen zijn én tot stand horen te komen. Dit laatste behoorde volgens het logisch empirisme tot de ondekkingscontext. Door deze meer dynamische invulling van de rechtvaardigingscontext, die voortvloeit uit Poppers kennistheorie, nodigt Poppers werk er eerder dan het 
logisch empirisme toe uit de feitelijke rechtwaardigingspraktijk historisch te 'toetsen" op de uit zijn wetenschapstheorie af te leiden verwachtingen. Naar aanleiding van Poppers wetenschapstheorie rijst de vraag in hoeverre zijn wetenschapstheorie (historisch) adequaat is voor een beschrijving van de rechtvaardigingspraktijken die we in het onderzoeksproces aantreffen. Popper zelf heeft uitgesproken ideeẽn over hoe rechtvaardigingspraktijken er uit zouden moeten zien. ${ }^{6}$ Uitgaande van zijn kennistheorie verwacht hij dat onderzoekers conform de uit die kennistheorie afgelleide deductieve stijl werken. Dit heeft als consequentie dat de feitelijke rechtvaardigingspraktijk op een bepaalde wijze georganiseerd moet zijn: onderzoekers behoren hun onderzoeksresultatem op een specifieke wijze te presenteren. Popper meent bijvoorbeeld dat artikelen op een specifieke manier moeten worden geschreven: een artikel moet beginnen met een duidelijke uiteenzetting van een probleem, waarna een overzicht volgt van de relevante hypothesen met betrekking tot dat probleem. Vervolgens moet een uiteenzetting worden gegeven van de experimentele resultaten in het licht van de hypothesen en ten slotte een evaluatie waarin besproken wordt of en zo ja hoe de probleemsituatie is veranderd. Experimenteel geproduceerde waarnemingen dienen te worden gebruikt om na te gaan of theorieën globaal juist of onjuist zijn.

In deze schets van hoe de feitelijke rechtvaardigingspraktijk eruit zou moeten zien, is de onderliggende structuur van Poppers deductieve methodologie te herkennen. Volgens Popper worden theorieën naar aanleiding van problemen verzonnen, waarna de uit die theorieën logisch afgeleide hypothesen (basisuitspraken) in experimenten kunnen worden getest. In de feitelijke rechtvaardigingspraktijk is met andere woorden de gestileerde rechtvaardiging, die voortvloeit uit de deductieve methodologie, te herkennen. Voor de epistemologische verantwoording van deze praktijk kan vervolgens een beroep worden gedaan op Poppers kennistheorie.

\section{3}

\section{Popper en de inductieve stijl}

Popper verdedigt een eenheid van methode in de empirische wetenschappen. Hij verwacht dat onderzoekers conform de uit zijn epistemologie afgeleide deductieve stijl te werk gaan. De inductieve stijl speelt volgens hem in de ontwikkeling van wetenschap geen rol van betekenis. Deze wetenschapstheoretische positie heeft Popper op verschillende niveaus beargumenteerd, zodat het voor een nadere analyse van het 
probleem wan de twee methodologische stijlen handig is een aantal niveaus in de discussies over de deductieve en de inductieve stijl expliciet te onderscheiden.

Onder de noemer 'methodologische stijlen' worden op tenminste vier niveaus discussies gevoerd. In de eerste plaats wordt de filosofische discussic tussen de deductieve en inductieve traditie gevoerd op een epistemologisch niveau. Op dit niveau is de kennistheoretische en logische juistheid van twee stijlen in het geding en wordt de discussie in normatief filosofische termen gevoerd. Poppers kennistheoretische en logische kritiek op het inductivisme is hiervan een voorbeeld. In de tweede plaats wordt de discussie gevoerd op het niveau van de methodologische idealen die voortvloeien uit de epistemologische tegenstelling. Deductivisten benadrukken het belang van het kritisch testen van theorieën en verwachten weinig heil van het aaneenrijgen van feiten. Inductivisten daarentegen leggen de nadruk op complexiteit van de wereld, het belang van een precieze en voorzichtige werkwijze, en waarschuwen voor het gevaar van vooroordelen. Uit de deductieve en inductieve filosofie worden met andere woorden criteria afgeleid waaraan goed onderzoek idealiter zou moeten voldoen. In de derde plaats wordt de discussie gevoerd op het niveau van het feitelijk handelen van onderzoekers. De rechtvaardigingspraktijken die we in de wetenschap aantreffen zijn op een bepaalde manier gestructureerd en kunnen respectievelijk als 'inductief' of 'deductief worden omschreven. Op dit niveau geven onderzoekers tevens vaak een verantwoording voor hun handelingspraktijken in termen van de deductieve of inductieve methodologische idealen. Newtons uitspraak: 'hypotheses non fingo' en Darwins bewering, dat hij via zuiver Baconiaanse wegen tot zijn evolutietheorie is gekomen, zijn veel bediscussieerde voorbeelden van het laatste. In de vierde plaats beweegt de discussie zich op het niveau van een wetenschapstheorie over het feitelijk handelen. Op dit niveau staat de vraag centraal in hoeverre het deductivisme en inductivisme als wetenschapstheorieën historisch-sociologisch adequaat zijn voor een verklaring van de methodologische handelingspraktijken.

Popper kritisch rationalisme beweegt zich op alle vier niveaus. Het uitgangspunt in zijn argumentatie ligt steeds op het vlak van de epistemologie. Hij heeft een deductivistische kennistheorie ontwikkeld en beargumenteerd waarom die epistemologisch superieur is ten opzichte van het inductivisme. Uit deze epistemologie heeft Popper methodologische idealen afgeleid die goede onderzoekers als leidraad zouden moeten nemen in hun onderzoek. Onderzoekers behoren volgens de deductieve benadering hun onderzoek in te richten en te rechtvaardigen, omdat deze benadering epistemologisch superieur is. Uitspraken 
van onderzoekers over hun feitelijk methodologisch handelen interpreteert Popper vervolgens vanuit zijn epistemologische positie en methodologische idealen. Het inductivisme is volgens hem epistemologisch niet te rechtvaardigen en heeft tot 'verkeerde' methodologische idealen geleid. Wanneer onderzoekers zeggen dat zij zich in bun feitelijk handelen hebben laten leiden door het inductivisme, dan moet deze inductheve retoriek met de nodige scepsis worden bekeken. Darwin bijvoorbeeld mag dan wel beweren dat hij via zuiver Baconiaanse wegen tot zijn evolutietheorie is gekomen, maar een analyse van zijn feitelijk methodologisch handelen zal volgens Popper echter laten zien dat dit niet het geval was. Hoewel Darwin zijn werkwijze verwoordde in termen van de inductieve methodologische idealen, wil dat immers nog niet zeggen dat hij in zijn feitelijk handelen inductief te werk ging. De manier waarop Darwin zijn theorie ontwikkelde kan volgens Popper met behulp van zijn wetenschapstheorie in een deductieve terminologie worden gereconstrueerd.

Naast een inductieve retoriek in termen van methodologische idealen, treffen we in met name de levenswetenschappen ook inductieve rechtvaardigingspraktijken aan. Deze inductieve praktijken kunnen natuurlijk met behulp van de inductieve filosofie worden gerechtvaardigd, maar voor Popper is deze weg afgesloten. Omdat het inductivisme als filosofie niet te rechtvaardigen valt, kan volgens Popper de inductieve praktijk niet in termen van de inductieve wetenschapstheorie worden verklaard.

Voor een nadere analyse van de deductieve en de inductieve stijl is vooral Poppers alternatieve interpretatie van inductieve praktijken in termen van zijn deductieve wetenschapstheorie interessant. Hij moet immers laten zien dat zelfs inductieve praktijken in termen van de deductieve wetenschapstheorie kunnen worden geinterpreteerd. Op Poppers argumentatie zal ik nu uitvoerig ingaan.

De deductieve stijl is volgens Popper binnen de natuurwetenschappen geïnstitutionaliseerd tot deductieve rechtvaardigingspraktijken. In moderne artikelen, geschreven binnen disciplines als de fysica en de chemie, zijn de rechtvaardigingspraktijken meestal gestructureerd zoals Popper verwacht dat zij zouden zijn georganiseerd. Niettemin komt de tegenovergestelde inductivistische variant volgens Popper voor in (met name) de levenswetenschappen. In biologische tijdschriften vindt men vaak een feitelijke rechtvaardigingspraktijk die overeenkomt met wat de traditie van de inductieve filosofie suggereert. Dergelijke artikelen beginnen met een uitleg van hoe de experimentele setting is geprepareerd. ${ }^{7}$ Daarna volgt een uitgebreide beschrijving van de zuivere waarnemingen en de experimentele resultaten, waarna een evaluatie wordt 
gegewen van de betrouwbaarheid van de resultaten met behulp van statistiek. Soms worden de resultaten dan vergeleken met door andere onderzoekers verkregen resultaten; soms volgen suggesties voor verbeteringen van de proefopzet of voor toekomstige waarnemingen. Het artikel wordt meestal afgesloten met een korte epiloog waarin een hypothese wordt gesuggereerd op grond van de experimentele resultaten. De gestileerde rechtvaardiging van deze praktijk lijkt de inductieve filosofie te zijn: zorgvuldige, niet door theoretische vooroordelen beinvloede, waarnemingen vormen de bouwstenen voor het inductief ontwikkelen van algemene kennis. Waarnemingen lijken hier gebruikt te worden om in de lokale onderzoekssituatie hypothesen tot ontwikkeling te brengen.

Hoewel de inductieve stijl dus lijkt voor te komen in de biologie, berust dit volgens Popper op een misverstand. De inductieve stijl is volgens hem een filosofische fictie uit het verleden omdat deze stijl epistemologisch niet te verantwoorden is. Inductieve rechtvaardigingspraktijken kunnen volgens Popper dan ook niet met een inductieve wetenschapstheorie worden geinterpreteerd, omdat de inductieve filosofie epistemologisch niet te rechtvaardigen is. De handelingspraktijken die worden omschreven als 'inductieve rechtvaardigingspraktijken' verhullen volgens hem dat $66 \mathrm{k}$ in de biologie de deductieve stijl gangbaar is. De feitelijke rechtvaardigingspraktijken zijn namelijk volgens Popper anders georganiseerd dan de inductieve stijl suggereert en zij kunnen worden verklaard met de deductieve wetenschapstheorie. De deductieve stijl is in de levenswetenschappen volgens Popper nog niet geïnstitutionaliseerd tot een rechtvaardigingspraktijk in tijdschriften, maar is informeel georganiseerd in een orale traditie. Theoretische verwachtingen worden in de biologie mondeling doorgegeven en selectie op die verwachtingen vindt grotendeels plaats in de orale traditie.

Deze interpretatie van (ogenschijnlijk) inductieve rechtvaardigingspraktijken in termen van zijn deductivistische wetenschapstheorie heeft Popper later gebruikt om historische kritiek op zijn wetenschapstheorie te ontzenuwen. Historici hebben Popper wetenschapstheorie bekritiseerd omdat volgens hen deductieve praktijken slechts in uitzonderingssituaties voorkomen. Kuhns kritiek op Popper is hiervan het bekendste voorbeeld. ${ }^{8}$ Volgens Kuhn worden studenten niet opgeleid om theorieën te testen, maar om puzzels op te lossen. Studenten worden volgens Kuhn niet kritisch, maar betrekkelijk dogmatisch gesocialiseerd in een wetenschappelijke gemeenschap. $\mathrm{Zij}$ leren, door maatgevende voorbeelden in handboeken te bestuderen, problemen op te lossen naar het model van reeds opgeloste problemen. Daarbij dienen zij de theorie, die hen in staat stelt problemen op te lossen, niet ter discussie te stellen. 
De theorie fungeert bij het oplossen van problemen in Kuhns visie niet als zoeklicht, maar als achtergrond waartegen nieuwe problemen worden gesignaleerd die vervolgens met de geaccepteerde theorie kunnen worden aangepakt. In de essentuële spanning tussen behoudzucht en vernieuwing die de ontwikkeling van wetenschap kenmerkt ligt de nadruk in 'normale wetenschap' volgens Kuhn eerder op behoudzucht.

Poppers antwoord op Kuhns kritiek heeft ten dele een normatief en ten dele een historisch-empirisch karakter. Wanneer onderzoekers dogmatisch worden gesocialiseerd, dan is het slecht gesteld met de wetenschap, zo luidt het normatieve gedeelte van zijn antwoord. ${ }^{9}$ Voor het probleem van de twee methodologische stijlen in het historisch-empirisch argument interessanter. Uit zijn beschouwing over de rechtvaardigingspraktijken heeft Popper een argument gedestilleerd waarmee hij de kritiek, dat onderzoekers niet deductief theorieèn zouden ontwikkelen, kan ontkrachten. Hoewel het lijkt dat onderzoekers niet deductief te werk gaan, zal gedetailleerd historisch onderzoek volgens Popper uitwijzen dat zij feitelijk een deductieve methodologie gebruiken. ${ }^{10} \mathrm{De}$ historicus wordt volgens Popper misleid door de inductieve rechtvaardigingspraktijken. Hoewel inductieve rechtvaardigingspraktijken gangbaar lijken te zijn in - bijwoorbeeld - de biologie, maskeren deze praktijken dat onderzoekers feitelijk onderzoek verrichten in de traditie van de deductieve stijl. Wanneer historici meer oog hadden gehad voor de orale traditie in de biologie, dan hadden zij ontdekt dat de deductieve stijl nog niet geinstitutionalseerd is tot een deductieve rechtvaardigingspraktijk. De consequenties van Poppers antwoord op de historische kritiek op zijn wetenschapstheorie zijn duidelijk. Wie afgaat op met name tijdschriften wordt mislleid door de inductieve rechtvaardigingspraktijken en kan ten onrechte tot de conclusie komen dat biologen niet deductief te werk gaan.

\section{4}

De ontdekking van penicilline

Ter illustratie van zijn stelling, dat ogenschijnlijk inductieve praktijken met een deductieve wetenschapstheorie kunnen worden geinterpreteerd, heeft Popper de ontdekking van penicilline besproken. ${ }^{11}$ In het nu beroemde artikel uit 1929 beschrijft Fleming zijn ontdekking volgens Popper conform de methodologische idealen van de inductieve filosofie. Fleming presenteerde zijn bevindingen door de observaties en experimenten op te sommen zonder theoretische bespiegelingen. De onschuldige lezer (bijvoorbeeld een historicus of een filosoof) wordt 
volgens Popper hierdoor misleid. Flemings onderzoek was namelijk terdege wel gemotiveerd door een specifieke theoretische verwachting hoewel die nergens wordt vermeld. En inderdaad: sinds 1870 was al bekend dat schimmelsoorten toxische stoffen afscheiden gericht tegen bacteriën. Het centrale probleem was volgens Popper dan ook een stof te vinden die geschikt was voor medische doeleinden. Fleming vermoedde volgens Popper dat penicilline geschikt was, maar kon zijn vermoeden niet bevestigen omdat hij niet met een competente chemicus aan dit probleem kon werken. Gelukkig werd zijn vermoeden via de orale traditie doorgegeven, zodat het ruim tien jaar later door Florey en zijn medewerkers werd bevestigd.

Twee aspecten van Poppers deductivistische reconstructie wil ik nu onder de historische loep nemen: (1) was Flemings waarneming inderdaad een voorbeeld van een theorie-gestuurde waarneming, en (2) vermoedde Fleming dat penicilline geschikt was voor medische doeleinden?

Flemings ontdekking staat te boek als een toevalsontdekking. Hij heeft nooit precies beschreven hoe de schimmel in zijn petrischaal met Staphylococcen verzeild is geraakt. Naar eigen zeggen is de schimmel toevallig in een petrischaaltje terecht gekomen dat hij tijdens een vakantie apart had gezet. Een van de problemen waar historici achteraf voor staan is dat Penicillium-schimmels alleen op een agarplaat met Staphylococcen kunnen groeien indien eerst de schimmel is aangebracht en daarna de bacterie. Het omgekeerde kan niet, behalve in een uitzonderingssituatie: de temperatuur moet dan eerst relatief laag worden gehouden. Dat laatste zou nu het geval kunnen zijn geweest bij Flemings waarneming. In de periode dat Fleming op vakantie was is de temperatuur in Londen eerst laag geweest waardoor een verdwaalde Penicillium-schimmel zich te midden van de bacteriën kon nestelen in eén van de petrischalen die Fleming toevallig apart had gezet. Flemings waarneming was dus verre van theorie-gestuurd en lijkt veeleer een toevalskarakter te hebben. Volgens Popper was dit echter niet het geval. Zelfs 'chance-observations' zijn volgens hem een voorbeeld van de trial and error-methode. 'A "chance-observation" is like an unexpected stone in our path: we stumble over it just because we did not expect it - or more precisely because we did expect, though unconsciously, that the path would be smooth'. ${ }^{12}$ Toevalsontdekkingen zijn daarom niet zo 'toevallig' als zij op het eerste gezicht lijken te zijn. Deze interpretatie van Flemings ontdekking bevat een korrel waarheid. Uit het vervolgonderzoek blijkt dat Fleming snel doorkreeg dat Penicillium-schimmels alleen op een agarplaat met Staphylococcen kunnen groeien indien eerst de schimmel is aangebracht en daarna de bacterie. De interpreta- 
tie van het waargenomen effect was dus snel gevonden. Betekent dit nu dat Flemings waarnemingen aansloten bij een theoretische verwachting? Was de ontdekking het resultaat van cen theorie-gestuurde waarneming? Volgens Popper was dit het geval: 'Moreover, Fleming was very much alive, even prior to his discovery, to the possible significance of this kind of effect for therapeutic purposes. ${ }^{13}$ Al voórdat Fleming zijn ontdekking deed was hij volgens Popper op zoek naar een interessant antibioticum. Als dàt het geval is, dan is Poppers wetenschapstheoretische interpretatie correct. Deze interpretatie stuit echter op een drietal anomalieën. ${ }^{14}$

Ten eerste heeft Fleming, nadat hij de effecten van penicilline op verschillende bacteriesoorten had uitgetest, twee medewerkers opdracht gegeven de chemische eigenschappen van penicilline te onderzoeken, en kon dus wel met competente chemici aan 'het probleem' werken. Curieus is echter dat Fleming nauwelijks belangstelling had voor de resultaten van dit onderzoek. Ten tweede was Flemings onderzoek feitelijk gericht op een geheel ander probleem en dat vinden we ook terug in de titel van het artikel uit 1929: 'On the antibacterial action of cultures of a Penicillium with special reference to their use in the isolation of B. Influenzae'. Het artikel is voor een belangrijk deel gewijd aan Flemings ontdekking dat penicilline een handig reagens was om bacteriën van elkaar te scheiden. Met name Haemophilus (of Bacillus) influenzae, waarvan men vermoedde dat het de oorzaak was van infecties aan de luchtwegen, bleek ongevoelig te zijn voor penicilline en kon dus met behulp van deze stof worden geisoleerd. Dit aspect trok ook de aandacht van andere onderzoekers, zoals Dreyer in Oxford, die hem om een sample van zijn Penicilliumcultuur vroegen. Daarmee komen we aan de derde en voor Poppers reconstructies meest lastige anomalie. Vermoedde Fleming wel dat penicilline geschikt was voor medische doeleinden? Waarom testte hij penicilline dan niet systematisch uit op dieren? Waarom stopte hij met zijn onderzoek in 1929? En waarom probeerde hij niet andere onderzoekers van het belang van penicilline te overtuigen?

Flemings artikel uit 1929 bleef onbekend omdat Fleming niet vermoedde dat penicilline van therapeutisch belang was. Zijn onderzoek was er één uit vele en nergens bleek dat Penicillium notatum bijzondere medisch eigenschappen had. Wat wel belangrijk was bij het verdere onderzoek was Flemings suggestie dat penicilline een handig hulpmiddel was. De sample die Dreyer had ontvangen zou later door Florey voor onderzoek worden gebruikt.

De ontdekking van de klinische toepassingsmogelijkheden van penicilline werd dan ook niet gedaan door Fleming, maar door Florey en 
zijn medewerkers in Oxford. Na hun werk aan het verschijnsell lysis, waar ook Fleming aan had gewerkt, raakten zij geïnteresseerd in antibacteriële stoffen. In 1938 besloten zij drie al bekende stoffen aan een nader onderzoek te onderwerpen, waaronder Flemings penicilline. $\mathrm{Zij}$ hadden daarvoor contact kunnen opnemen met Fleming, maar het toeval wilde dat Florey de opvolger was geworden van Dreyer en die had al een sample van Flemings Penicillium-cultuur in 1929 ontvangen. $\mathrm{Na}$ vooronderzoek vain de biochemicus Chaïn, die in eerste instantie -zonder het te weten- grote delen van het onderzoek van Flemings medewerkers herhaalde, werd hen duidelijk dat penicilline de meest interessante van de drie was en van praktisch belang zou kunnen zijn. In 1939 besloten zij dan ook over te gaan op een in vivo-test. Weliswaar waren er problemen rond extractie van het werkzame bestanddeel, maar begin 1940 beschikten Florey c.s. over voldoende penicilline voor een test op muizen. De resultaten van dit experiment waren spectaculair: muizen, eerst ingespoten met lethale doses virulente Streptococcen, bleken na behandeling met penicilline te genezen, terwijl muizen in de blancogroep onderwijl bezweken. Hoewel Florey c.s. na dit experiment overtuigd waren van het praktisch belang van penicilline, slaagden zij er niet in farmaceutische firma's ervoor te interesseren. Met name de problemen rond de extractiemethoden vormden een struikelblok, temeer daar de behandeling van mensen in vergelijking met muizen circa 3000 keer zoveel penicilline vereiste. Niet uit het veld geslagen besloot Florey daarop het laboratorium om te bouwen tot een penicillinefabriek om de productie te verhogen. Begin 1941 beschikten zij over voldoende penicilline voor een test op mensen. Ethische overwegingen deed hen besluiten patiënten te kiezen die ten dode waren opgeschreven. Van de zes behandelde patiënten genazen er vier; één stierf als gevolg van een complicatie en een ander omdat er te weinig penicilline voorradig was en de behandeling te kort was geweest.

Onderwijl was Fleming in 1940 na de publicatie van het muizenexperiment op bezoek geweest. Na binnenkomst schijnt hij gezegd te hebben: 'I've come to see what you've been doing with my old penicillin'. ${ }^{15}$ Maar ook dit bezoek overtuigde hem niet van het medisch-klinisch belang van penicilline. Eind 1942 kwam daar verandering in toen Fleming zelf een patiënt met de penicilline uit Oxford genas en voor het eerst de werking ervan zag. Nadat Fleming het effect van penicilline had gezien in een in vivo-experiment raakte hij dus overtuigd van het therapeutisch belang. 'Seeing is believing', schrijft MacFarlane in zijn Fleming-biografie, waarmee de geest van deze 'omwenteling' goed wordt weergegeven.

Poppers deductivistische reconstructie van Flemings ontdekking is in het voorafgaande gekritiseerd. Flemings ontdekking was niet 'ge- 
stuurd' door een theorie en zijn onderzoek was al evenmin gericht op het testen van een theorie. Welke consequenties heeft deze kritiek op Poppers wetenschapstheoretische interpretatie van Flemings onderzoek voor het onderscheid tussen de deductieve en inductieve stijl?

Voor Popper zijn de deductieve stijl en de inductieve stijl twee tegengestelde stijlen waarbij de inductieve stijl epistemologisch niet te rechtvaardigen is. Deze methodologische tegenstelling is volgens hem de vertaling van de filosofische tegenstelling tussen de Zoeklichttheorie en de Emmertheorie van de geest. Deductief onderzoek betekent dat onderzoek gericht is op het testen van theorieën; inductief onderzoek wil zeggen dat onderzoekers eerst data verzamelen en dan op grond van die data een algemene wet formuleren. Het (Popperiaanse) standaardvoorbeeld van inductief onderzoek is natuurlijk de inductieve generallisatie: 'Alle zwanen zijn wit' uit een $\mathrm{x}$-aantal waarnemingsuitspraken. Deze vorm van inductief onderzoek is volgens Popper epistemologisch niet te rechtvaardigen en kan daarom niet als rechtvaardigingspraktijk voorkomen. Zij was ook niet van toepassing op het werk van Fleming: er was immers geen sprake van een inductieve generalisatie, maar van een interpretatie. Maar uit het feit dat Fleming een nieuw verschijnsel interpreteerde, volgt niet dat zijn feitelijk handelen in termen van een deductieve wetenschapstheorie kan worden gereconstrueerd. Flemings interpretatie was immers niet afgeleid uit een nieuwe theorie, maar kwam tot stand doordat Fleming een verschijnsel interpreteerde in termen van achtengrondkennis. Sinds 1870 was al bekend dat schimmels toxische stoffen afscheiden gericht tegen bacteriën en het was deze (microbiologische) kennis die Fleming gebruikte bij zijn interpretatie van zijn toevalsontdekking. Deze achtergrondkennis fungeerde niet als zoeklicht, noch als 'emmer', maar eerder als fonds dat bruikbaar was voor de interpretatie van fenomenen.

We kunnen nu ook werklaren waardoor Popper deze alternatieve mogelijkheid over het hoofd heeft gezien. Doordat Popper de filosofische tegenstelling tussen de inductieve en de deductieve traditie gebruikt voor een interpretatie van feitelijke handelingspraktijken, komt hij voor de vraag te staan of de rechtvaardigingspraktijk deductief dan wel een inductief is georganiseerd. Wanneer hij vervolgens -terechtconstateert dat inductieve generalisaties geen rol spelen in de inductieve rechtvaardigingspraktijk, moet hij concluderen dat deze praklijk verhult dat onderzoekers deductief te werk gaan. 
De eerste les die we uit de reconstructie van Flemings ontdekking kunnen trekken is dat het onderscheid tussen de inductieve en de deductieve stijl niet te verklaren is in termen van de filosofische tegenstelling tussen het inductivisme en het deductivisme. Er zijn verschillen tussen deductieve en inductieve rechtvaardigingspraktijken, maar deze verschillen kunnen noch met Poppers deductivistische wetenschapstheorie, noch met de inductivistische wetenschapstheorie, worden verklaard. De alternatieve interpretatie van Flemings onderzoek heeft een nieuwe methodologische tegenstelling opgelleverd. Deductief onderzoek is het testen van nieuwe theorieën door theorieën op hun toetsbare consequenties te onderzoeken. Het 'doel" van deductief onderzoek is -in de woorden van Popper- het verklaren van het bekende in termen van het onbekende. ${ }^{16}$ Daarvoor zal het bekende eerst geproblematiseerd moeten worden. Inductief onderzoek is het verklaren van (nieuwe) fenomenen in termen van het bekende; fenomenen worden in termen van een geaccepteerde theorie geinterpreteerd. Het 'doel' van inductief onderzoek is het uitbreiden van het domein waarop de (geaccepteerde) theorie van toepassing is. Wanneer we de tegenstelling zó formuleren, dan sluit zij naww aan bij Kuhns kritiek op Popper. ${ }^{17}$ Net als Popper heeft Kuhn verdedigd dat inductieve generalisaties in de wetenschap geen essentiële rol spelen. Maar in tegenstelling tot Popper heeft Kuhn beargumenteerd dat hier niet uit volgt dat onderzoekers altijd deductivistisch te werk gaan. Een groot deel van het wetenschappelijk onderzoek is volgens Kuhn niet gericht op het testen van theorieën. Popper heeft zijn falsificatie-criterium volgens Kuhn ontleend aan relatief zeldzame perioden in de wetenschap, die Kuhn revolutionaire wetenschap heeft genoemd. In deze perioden ontwikkelen onderzoekers inderdaad nieuwe theorieën die zij op hun toetsbare consequenties onderzoeken. Deze perioden worden volgens Kuhn echter vooraf gegaan en gevolgd door perioden van normale wetenschap. Typisch voor normale wetenschap is volgens Kuhn dat onderzoekers theorieën als achtergrondkennis gebruiken voor het formuleren van hypotheses, door een probleem in termen van de achtergrondkennis te herformuleren. Welliswaar worden vervolgens die geformuleerde hypothesen getest, maar deze testprocedure heeft volgens Kuhn een geheel ander karakter dan men op grond van Poppers wetenschapstheorie zou vermoeden. Tijdens normale wetenschap wordt niet de theorie getest, maar de onderzoeker. 
Kuhns karakteristiek van normale wetenschap lijkt dus veel op wat hier de inductieve benadering of stijl is genoemd. Centraal staat in beide gevallen dat de theorie die wordt gebruikt woor het formuleren van hypothesen niet ter discussie staat. Die fungeert niet als zoeklicht maar als fonds voor het formuleren van hypothesen. Daarom heeft het testen van hypothesen een ander karakter dan het Popperiaans testen van theorieên. Aan de hand van een voorbeeld uit de immunologie kan dit nader worden uitgewerkt.

De immunologische reactie van organismen op ziekteverwekkers heeft een drietal typische kenmerken. Ten eerste bestaat er bij het eerste contact met een ziekteverwekker nog geen immuniteit. Blijkbaar moet er iets in het lichaam worden aangemaakt dat voor immuniteit zorgt. Ten tweede werkt de immuniteit zeer gericht. Na bijwoorbeeld een mazeleninfectie ontwikkelt zich alleen immuniteit tegen mazelen. Ten derde is verworven immuniteit niet overerfbaar. Deze 'alledaagse' kenmerken roepen natuurlijk vragen op over de aard van de immunologische reactie. Allereerst is van belang wat er door het lichaam wordt aangemaakt. Eind vorige en begin deze eeuw werd duidelijk dat organismen antilichamen (eiwitten) maken die kunnen binden met de ziekteverwekker. Daarmee was het probleem van de specificiteit van de immunologische reactie natuurlijk nog niet opgelost, maar dat probleem kon nu wel preciezer worden geformuleerd: hoe komt het dat organismen antilichamen kunnen aanmaken die met specifieke antigenen kunnen binden? Dit algemene probleem is door verschillende chemici in deze eeuw onderzocht. Het voorafgaande onderzoek stelde chemici in staat om het probleem van de specificiteit op te vatten als een moleculair probleem, oftewel: chemici konden er een chemisch probleem van maken. In zijn overzichtsartikel formuleerde Karush de chemische vraagstelling als volgt: "what properties does the antibody molecule possess which confers upon it the capacity to recognize and to combine selectively with the antigen which had induced the antibody? ${ }^{18} \mathrm{Het}$ algemene probleem was hiermee tot hanteerbare proporties teruggebracht en kon vervolgens worden onderzocht. Daartoe hebben chemici het probleem verder verfijnd door het in een specifieker chemische model te vertalen. In de meeste studies ging de aandacht uit naar de relatie tussen de immunologische specificiteit en de structuur van moleculen, zodat het probleem in een structuralistische terminologie kon worden geformuleerd. Karush formuleerde deze precisering als volgt: 'in what ways and to what extent does the selectivity (or recognition) involved in the reaction of antigen and antibody depend on the structure of these molecules? ${ }^{19}$ Hoewel ook dit probleem nog niet direct te toetsen was, maakte deze formulering wel experimenteel-che- 
misch onderzoek mogelijk. Een aantal hypothesen lagen nu min of meer voor de hand. Onderzocht werd welke interspecifieke bindingen (bijvoorbeeld waterstofbindingen of apolaire bindingen) bij de antilichaam-antigeen interacties in het spel zijn, of de affiniteit tussen antigenen en antilichamen met behulp van equilibrium dialyse technieken kon worden bepaald, hoe groot de 'bindingsplaats' van het antilichaam was, etcetera. Telkens kon een verwachting worden geformuleerd die vervolgens experimenteel werd getoetst. Uiteraard kwamen die verwachtingen niet altijd uit.

Op het eerste gezicht lijkt deze werkwijze van de chemici veel op het Popperiaans problemen oplossen. Een immunologisch probleem was de aanleiding om een chemische theorie te verzinnen over de immunologische reactie. De verwachting werd geformuleerd dat de specificiteit van de immunologische reactie kon worden verklaard in termen van intermoleculaire krachten, etcetera, en deze verwachting werd getoetst in experimenten.

Nadere inspectie leert echter dat hier geen sprake is van een Popperiaanse testprocedure. De hypothesen die door chemici werden geformuleerd waren niet afgeleid uit een nieuwe theorie. Achtergrond- of geaccepteerde kennis, in dit geval chemische theorieën over de structuur van moleculen, werd door chemici in verband gebracht met een specifiek probleem: de specificiteit van de immunologische reactie. De achtergrondkennis gebruikten zij om dit probleem in termen van chemische theorieën over de structuur van moleculen te herformuleren zodat hypothesen konden worden opgesteld. Daarmee waren de puzzels waaraan zij werkten geformuleerd. Deze hypothesen werden door hen getest. Maar omdat niet de achtergrondkennis werd getest maar door de onderzoeker geformuleerde hypothesen, kon het falen van een test per definitie niet aan die achtergrondkennis worden toegeschreven. Hun persoonlijke vermoedens werden getest. Als de onderzoekers inventief waren, konden zij de puzzel oplossen; mislukte een toets, dan faalden de onderzoekers. Dit bedoelt Kuhn wanneer hij stellt dat tijdens normaal wetenschappelijk onderzoek niet de theorie wordt getest, maar de onderzoeker.

De wijze waarop onderzoekers hypothesen testen heeft als consequentie dat de geaccepteerde theorie die wordt gebruikt voor het formuleren van hypotheses nooit ter discussie staat. Hoe kan de geaccepteerde theorie dan ooit ter discussie komen te staan? Volgens Kuhn komen onderzoekers vroeg of laat een anomaal geval tegen dat niet via puzzeloplossen te verklaren is. In welk toepassingsdomein van de theorie zo'n anomalie 'ligt' kan niet van tevoren worden vastgesteld. Eerst zullen onderzoekers volgens Kuhn de anomalie niet als zodanig herken- 
nen en proberen met behulp van de geaccepteerde theorie een oplossing te vinden. Wanneer deze strategie niet lukt, dan zullen zij via ad hoc modificaties de schijnbare tegenstelling tussen de anomalie en de theorie proberen te elimineren. Wanneer zelfs deze strategie niet succesvol verloopt, zal de anomalie als een serieus tegenvoorbeeld worden herkend. Vaak is op dat moment al een alternatieve theorie ontwikkeld. Problemen rond de straling van zwarte lichamen bijvoorbeeld werden door fysici lange tijd niet als anomale gegevens gezien. Men verwachtte dat de problemen met behulp van de klassieke fysica zouden worden opgelost. Nadat deze pogingen telkens op een mislukking uitliepen, ging men op zoek naar een nieuwe theorie. Toen een oplossing was gevonden met behulp van het quantum-postulaat, herkende men pas dat de problemen rond de straling van het zwarte lichaam in feite anomalieën waren voor de klassieke fysica. ${ }^{20}$

Op grond van historisch onderzoek heeft Kuhn een algemene wetenschapsfilosofie ontwikkeld die aanzienlijk complexer is dan die van Popper. In plaats van gestadig probleemoplossen, wordt volgens Kuhn kennisgroei bewerkstelligd door de afwisseling van puzzeloplossen en probleemoplossen. In hoofdstuk drie zal nader op Kuhns wetenschapsfilosofie worden ingegaan, met name op zijn incommensurabiliteitsthese die nauw samenhangt met Kuhns kritiek op Poppers kritisch rationalisme. Voor de probleemstelling in dit hoofdstuk is voorlopig de methodologische tegenstelling tussen probleemoplossen en puzzeloplossen van belang. Deze tegenstelling kan worden gebruikt om de twee methodologische stijlen nader te karakteriseren. Welke systematische verschillen kunnen we op grond van deze tegenstelling verwachten in de onderzoekspraktijk?

\section{6 \\ Methodologie en onderzoekspraktijk ${ }^{21}$}

Wanneer (Kuhniaans) puzzeloplossen het centrale kenmerk is van de inductieve stijl, dan is geaccepteerde kennis in deze benadering de basis voor innovaties. Omdat geaccepteerde kennis de basis vormt voor verder onderzoek, zullen onderzoekers een conservatieve houding hebben tegenover verworven inzichten en ontzag voor de producenten van die kennis. Speculatie zal worden gewantrouwd, voorzichtigheid voert de boventoon. Samenwerking zal voorop staan en onderzoekers zullen de wijze waarop problemen in termen van geaccepteerde kennis moeten worden geherformuleerd doorspreken met collega's. Voorzichtigheid komt bovendien voort uit het feit dat onderzoekers in de inductieve stijl 
fenomenen nauwkeurig dienen te beschrijven en precisie in acht moeten nemen bij het gebruik van meetprocedures. De geaccepteerde theorie, die wordt gebruikt woor de ontwikkeling van puzzels, zal in tijdschriften niet of nauwelijks worden vermeld. Daarvoor zullen onderzoekers in de inductieve stijl handboeken raadplegen.

De deductieve stijl, gekenmerkt door (Popperiaans) probleemoplossen, zal daarentegen worden gekenmerkt door durf. De formulering van speculatieve theorieên zal worden aangemoedigd; data zijn van belang in zoverre die theorieën kunnen bijstellen. Onderzoekers zullen in de deductieve stijl juist een kritische houding innemen tegenover bestaande kennis. Terwijl de omgangsvorm in de inductieve stijl wordt gekenmerkt door samenwerking, staat in de deductieve stijl juist concurrentie centraal. Dit laatste verschil vinden we ook terug in de instituties waarbinnen wetenschap wordt bedreven. Omdat in de inductieve stijl persoonlijke contacten belangrijk zijn en samenwerking op het eerste plan staat, is -in Poppers terminologie- de orale traditie institutioneel verankerd. Onderzoeksresultaten worden aan collega's voorgelegd en besproken op congressen vóór zij worden gepubliceerd. In de deductieve stijl worden onderzoeksresultaten beoordeeld na publicatie en komt de waarde van de bijdrage tot uitdrukking in het gebruik door anderen.

Dit latste verschil kunnen we bijwoorbeeld opmaken uit de houding van onderzoekers tegenover ontdekkingen. In de prioriteitenstrijd tussen Florey en Fleming rond de ontdekking van penicilline was de houding van Florey ambigu. ${ }^{22}$ Als leider van de onderzoeksgroep was hij de ontdekker van de therapeutische mogelijkheden van penicilline en kon hij prioriteit opeisen. Aan de andere kant was zijn onderzoek in zekere zin een voortzetting van Flemings werk zodat hij het steentje dat Fleming had bijgedragen respecteerde. Het feit dat zij persoonlijke contacten onderhielden en dat Florey c.s. werkten met een sample van Flemings penicilliumcultuur versterkte dit laatste alleen maar. In de deductieve stijl hebben onderzoekers geen ambigue houding tegenover andermans werk. Omdat in deductieve stijl eerst een theorie wordt verzonnen die pas later op haar merites wordt beoordeeld, is het cenvoudiger om vast te stellen wie de 'ontdekker' was. De klonale selectietheorie van Burnet was een typisch product van deductief onderzoek. Tegen de achtergrond van de toendertijd vigerende instructietheorie was deze theorie zeer speculatief, maar, zoals Burnet in zijn artikel schreef uit 1957, 'despite the speculative character (...) it has so many implications calling for experimental enquiry that it has been thought justifiable to submit this preliminary account for publication'. ${ }^{23}$ Burnet publiceerde zijn idee echter niet in een gerenommeerd tijd- 
schrift, maar in 'The Australian Journal of Science', voor onderzoekers buiten Australiè een 'exceedingly obscure journal: ${ }^{24}$ Burnet motiveerde deze keuze in zijn autobiografie als volgt: 'If the concept was eventually going to be recognized as important, I could establish priority in its old-fashioned sense by publishing in any reputable journal. On the other hand, I have always had an ambigiuous attitude to my own "bright ideas". ${ }^{25}$ Achteraf bezien was de klonale selectietheorie een zeer belangrijke bijdrage, maar dat kon óók Burnet nog niet weten toen hij zijn idee publiceerde. Dat bleek pas nadat de theorie een aantal tests had doorstaan. Vandaar Burnets ambigue houding: niet uit ootmoedigheid ten aanzien van andermans werk, maar uit twijfels over zijn eigen originaliteit. Wanneer zijn idee weinig waard was geweest, zouden slechts weinigen het hebben opgemerkt.

Deze opsomming van de cognitieve en sociale verschillen tussen de inductieve en deductieve stijl is uiteraard niet volledig. In figuur 2 staat een aantal van de cognitieve verschillen weergegeven. De voorlopige conclusie die we kunnen trekken is dat de meeste verschillen voortkomen uit de verschillen tussen het (Popperiaans) deductief testen van theorieën en het (Kuhniaans) puzzels oplossen.

Figuur 2

\section{Deductieve stijl}

1. Theorievorming gaat vooraf aan waarneming

2. Feiten worden gebruikt voor het bijstellen van theorieën

3. Fenomenen worden verklaard in termen van hypothetische mechanismen

4. De formulering van gewaagde theorieën wordt aangemoedigd

5. Experimenten dienen ter toetsing van theorieën
Inductieve stijl

1. Waarneming gaat vooraf aan hypothese vorming

2. Beschrijving van fenomenen en het verzamelen van feiten vormen het startpunt voor wetenschap

3. Nieuwe fenomenen worden geïnterpreteerd in termen van het bekende.

4. Speculatie wordt gewantrouwd.

5. Experimenten dienen om het toepassingsdomein van een theorie uit te breiden. 
6. Anomalieên of tegenvoorbeelden worden herkend en theoretisch geassimileerd

7. Kennis als een zoeklicht
6. Anomalieên of tegenwoorbeelden worden niet als zodanig herkend of binnen de kaders van de geaccepteerde theorie aangepast.

7. Kennis als een fonds

\section{7 \\ Slot}

Inductief en deductief onderzoek zijn twee verschillende stijlen van wetenschappelijk onderzoek. Inductief onderzoek is gericht op het uitbreiden van het domein waarop de theorie van toepassing is, deductief onderzoek is gericht op het ontwikkelen van nieuwe theorieën. Inductieve generalisaties spelen in beide benaderingen geen essentiële rol. Poppers tegenstelling tussen de Zoeklichttheorie en de Emmertheorie dient dan ook in methodologisch opzicht vervangen te worden door de nieuwe tegenstelling tussen probleemoplossen en puzzeloplossen.

Met deze nieuwe methodologische tegenstelling kan een complexer beeld worden geschetst van inhoudelijke ontwikkelingen in de levenswetenschappen. We kunnen nu beargumenteren waarom de inductieve stijl een gangbare methodologische stijl is in het wetenschappelijke onderzoek. Deze stijl hoeft niet langer in termen van een inductieve wetenschapstheorie te worden verklaard en kan ook niet in die termen worden verklaard. Evenzo kunnen we nu beargumenteren waarom de inductieve praktijken niet met een deductieve wetenschapstheorie kunnen worden geinterpreteerd. De manier waarop inductieve praktijken zijn georganiseerd kan niet met de klassieke tegenstelling tussen de deductieve en inductieve filosofie worden begrepen.

Deze verfijning van de methodologische tegenstelling tussen de twee stijlen heeft consequenties voor de beoordeling van inhoudelijke ontwikkelingen rondom het aanleg-omgeving vraagstuk in de levenswetenschappen. De (Popperiaanse) interpretatie van de affiniteiten tussen inhoudelijke en methodologische positie is te simplistisch. Omdat de inductieve stijl volgens Popper epistemologisch niet te rechtvaardigen is, velde Popper-vanwege de affiniteiten tussen methodologische en inhoudelijke posities- ook een negatief oordeel over inhoudelijke omgevingstheorieën. Nu de inductieve stijl een meer 'gelijkwaardige' positie heeft gekregen ten opzichte van de deductieve stijl, kunnen we niet 
alleen methodologische geschillen, maar ook inhoudelijke debatten tussen aanlegtheoretici en omgevingstheoretici op een meer symmetrische wijze analyseren.

In het volgende hoofdstuk zal een analyse worden gegeven van controversen tussen ethologen en behavioristen. Popper heeft de ethologische aanlegtheorie van Lorenz verdedigd tegenover de omgevingstheorie van Watson. Zo'n snelle kenze, die voortvloeit uit methodologische overtuigingen, zal ik hier niet maken. Integendeel: ik zal laten zien dat zowel ethologen als behavioristen inductief te werk gaan en de debatten tussen hen symmetrisch analyseren. Door de inhoudelijke controversen in termen van Kuhns wetenschapstheorie te beschrijven, zullen we tevens zien dat de kloof tussen aanleg en omgeving niet alleen tot controversen leidt, maar ook via puzzeloplossen te overbruggen is. 


\title{
3 \\ De ontwikkeling van gedrag De controverse tussen etho- logen en behavioristen
}

\author{
3.1 \\ Inleiding
}

In 1953 verscheen een artikel onder de titel: 'A critique of Konrad Lorenz"s theory of instinctive behavior". De schrijver was Daniel Lehrman, toen nog student vergelijkende en fysiologische psychologie. De titel laat over de inhoud van het artikel weinig twijfell bestaan: het is een gedegen kritiek op de ethologische theorie van Lorenz. In die kritiek stond Lehrman niet alleen. Ook vooraanstaande psychologen als Hebb en Schneirla hebben in het begin van de jaren vijftig uitgebreid kritiek geleverd op de ethologie.

De kritiek van Lehrman c.s. was het begin van een tweetal controversen over de betekenis van het gedragsembryologisch onderzoek van de psycholoog Kuo voor het aanleg-omgeving vraagstuk. In de eerste controverse, die voornamelijk op het niveau van de theoretische veronderstellingen speelde, stonden psychologen en ethologen tegenover elkaar. Volgens Lehrman en Schneirla liet het onderzoek van Kuo zien dat de traditionele dichotomie tussen aangeboren en aangeleerd gedrag in de ontwikkeling van gedrag onhoudbaar is. In de ontwikkeling van gedragseigenschappen spelen volgens hen zowel genetische als omgevingsfactoren een rol, zodat het geen zin heeft om over aangeboren gedragspatronen of instinctief gedrag te spreken. Dàt dieren over instinctief gedrag beschikken was het centrale element in de ethologische theorie van Lorenz en Tinbergen. $\mathrm{Zij}$ waren op basis van beschrijvend onderzoek tot de conclusie gekomen dat een deel van het gedrag instinctief is, aangezien sommige gedragspatronen soortspecifiek zijn en net als morfologische structuren vaste vormen hebben. De ontwikkeling van gedrag zagen Lorenzen Tinbergen als een proces waarin de aangeboren 
en aangeleerde elementen geleidelijk aan elkaar worden geschakeld. Oppervlakkig beschouwd lijken de theorie van Lehrman en Schneirla, en de theorie van Lorenz en Tinbergen niet veel te verschillen, maar uit de debatten die volgden op de kritiek van Lehrman c.s. komt een andere conclusie naar voren. Zo bleek dat Lorenz en Lehrman verschillende theorieen verdedigden waardoor zij voortdurend langs elkaar heen praatten en daarom ook niet echt tot overeenstemming kwamen. Andere psychologen en ethologen kwamen echter wel tot overeenstemming, bijvoorbeeld Lehrman en Tinbergen. Deze overeenstemming werd mogelijk doordat Tinbergen zich na verloop van tijd liet overtuigen.

De controverse tussen psychologen en ethologen kreeg in de jaren zestig een verlengstuk in de embryologie. In deze tweede controverse stonden niet zozeer de theoretische veronderstellingen ter discussie, als wel onderzoeksresultaten. De inzet van de controverse was wederon het onderzoek van Kuo. Door neuro-embryologen als Hamburger en Oppenheim werd de waarde van Kuo's gedragsembryologisch onderzoek in twijfel getrokken. Kuo zou zijn observaties en experimenten met een 'omgevingsbril' op hebben verricht en daardoor gevonden hebben dat omgevingsfactoren de ontwikkeling van embryonaal gedrag beinvloeden. Deze opvatting van Hamburger en Oppenheim werd door Kuo en de psycholoog Gottlieb bestreden. De standpunten bleken in de daaropvolgende debatten niet onverzoenlijk. Doordat Gottlieb, Hamburger en Oppenheim hun opvattingen voortdurend bijstelden werd omstreeks 1970 overeenstemming bereikt op het niveau van de onderzoeksresultaten.

Deze episode uit de geschiedenis van de psychologie zal ik in dit hoofdstuk nader onderzoeken. Twee punten vallen al direct op aan de eerste korte beschrijving. In de eerste plaats blijken onderzoekers in geschillen rond het aanleg-omgeving vraagstuk langs elkaar heen te praten. Er is sprake van communicatieproblemen die overeenstemming in de weg staan. In de tweede plaats blijken onderzoekers uit de aanlegen de omgevingstraditie, ondanks vermeende verschillen, uiteindelijk toch tot overeenstemming te kunnen komen. Omstreeks 1970 werd er zelfs overeenstemming bereikt op het niveau van de feiten. Naast communicatieproblemen is er dus sprake van een convergentie van twee onderzoekstradities. Wat zijn de achtergronden van de aanvankelijke communicatieproblemen? Welk ontwikkelingspatroon leidde tot convergentie? Resulteerde de convergentie in een nieuwe theorie waarin aanleg en omgeving zijn verenigd? Dit soort vragen worden in het historisch gedeelte van dit hoofdstuk uitwoerig besproken. Daarvoor zal ik de ontwikkeling van de onderlinge verhouding van de beide onderzoekstradities die in het geding zijn beschrijven. 
Daarnaast zal hier een wetenschapsfillosofische kwestie aan de orde komen. Wanneer er communicatieproblemen in controversen voorkomen, rijst de vraag of we niet te maken hebben met incommensurabiliteit in de zin waarin wetenschapsfilosofen en met name Kuhn deze term gebruiken. Was het geschil tussen Lorenz en Lehrman een discussie tussen vertegenwoordigers uit twee disciplinaire matrices? Hoeverhouden zich de twee oudere theorieën tot de nieuwe theorie? Deze wetenschapsfilosofische wragen zal ik in Kuhniaanse termen onderzoeken.

\section{2 Incommensurabiliteit}

Letterlijk betekent 'incommensurabel': 'niet-samen-te-meten" of 'niet-onderling-meetbaar' en het is deze, oorspronkelijk meetkundige, betekenis van de term die Kuhn gebruikt. ${ }^{1}$ In de meetkunde worden bijvoorbeeld de hypotenusa en de twee zijden van een gelijkbenige rechthoekige driehoek incommensurabel genoemd. 'What is lacking is not comparability but a unit of length in terms of which both can be measured directly and exactly. ${ }^{2} \mathrm{Er}$ is met andere woorden geen eenheid van termen waarin de lengte van de hypotenusa en van de zijden kunnen worden uitgedrukt. Iets vergelijkbaars geldt volgens Kuhn voor termen die uit verschillende theorieën afkomstig zijn, zoals 'beweging' bij Aristoteles en 'beweging' bij Galilei of 'massa' bij Newton en 'massa' bij Einstein. Oppervlakkig bezien termen die op hetzelfde soort zaken betrekking hebben; zij blijken bij nadere beschouwing echter niet tot elkaar te herleiden. Er is volgens Kuhn geen neutrale taal waarin deze termen zonder verlies van betekenis kunnen worden uitgedrukt. Aan de voorwaarden voor logische vergelijking is dan niet voldaan, omdat bij logische vergelijking wordt verondersteld dat de betekenis van termen gelijk blijft.

Naast deze logische-betekenis heeft de term 'incommensurabel' natuurlijk ook een functie in Kuhns wetenschapstheorie. Met zijn theorie wil hij verklaren hoe het komt dat theorieën of disciplinaire matrices incommensurabel zijn. Daarvoor heeft Kuhn de notie 'exemplar' geïntroduceerd. Het is volgens Kuhn niet voldoende om normal wetenschappelijk onderzoek in termen van puzzeloplossen te karakteriserem. De wijze waarop een theorie moet worden toegepast op een concrete probleemsituatie hebben onderzoekers tijdens hun opleiding geleerd aan de hand van exemplars die laten zien welke problemen aangepakt kunnen worden en hoe dat moet gebeuren. Door deze maatgevende voorbeelden te bestuderen leren onderzoekers problemen zien als pro- 
blemen die al opgelost zijn en maken zich zo een 'vermogen' eigen om toekomstige problemen naar het model van reeds opgeloste problemen aan te pakken.

Ter illustratie heeft Kuhn de tweede bewegingswet van de Newtoniaanse mechanica besproken. ${ }^{3}$ Het theoretisch basisschema (of de symbolische generalisatie) van deze wet is geen empirische propositie, maar kan worden gebruikt om proposities mee te vormen. Toegepast op de vrije val wordt $\mathrm{f}=$ ma getransformeerd in $\mathrm{mg}=\mathrm{m}\left(\mathrm{d}^{2} \mathrm{~s} / \mathrm{dt}^{2}\right)$. Het theoretisch basisschema fungeert hier als instrument waarmee in een bepaalde setting oplossingen voor problemen kunnen worden gegenereerd. Door deze toepassingen te bestuderen, leren fysicastudenten volgens Kuhn welk soort problemen hanteerbaar zijn voor de Newtoniaanse mechanica en wat de standaarden zijn waaraan oplossingen moeten voldaan. Zo leren zij wat de bedoelde toepassingen zijn van een theorie.

Omdat theoretische basisschema's geen empirische proposities zijn, kunnen zij ook niet worden gefalsificeerd. Theoretische basisschema's structureren het netwerk van een theorie en niet datgene wat de theorie beschrijft. Zij 'kanaliseren' het onderzoek, bepalen de manier waarop problemen worden gepercipieerd en constitueren de grenzen van de empirie. Daarom ondergaan studenten, wanneer zij aan de hand van exemplars problemen leren oplossen, volgens Kuhn een proces van 'perceptieverandering'.

In een periode van normale wetenschap bestaat er volgens Kuhn overeenstemming over de vraag wat de relevante problemen zijn, aangezien onderzoekers bepaalde prestaties als maatgevend beschouwen. In een periode van crisis vervallen deze maatgevende voorbeelden en dus de standaarden voor onderzoek omdat wordt ingezien dat de gangbare theorie geen oplossing geeft voor een steeds groeiend aantal anomalieën. De uitkomst van een wetenschappelijke revolutie kan dan ook niet aan de hand van standaarden worden geëvalueerd, want die veronderstellen een maatgevend voorbeeld. Veeleer gaat het volgens Kuhn om een 'blinde' acceptatie van een nieuwe theorie die wordt gekozen vanwege haar belofte voor de toekomst. Een wetenschappelijke revolutie betekent dus niet louter de falsificatie van de oudere theorie. De theoretische basisschema's die als instrument fungeerden voor de vorming van proposities worden na een revolutie vervangen door nieuwe schema's. De maatgevende voorbeelden zullen verschillen, de standaarden en de wijze waarop met theoretische basisschema's bedoelde toepassingen kunnen worden gegenereerd. De problemen voor en na een revolutie zullen anders worden gepercipieerd en de 'taal' waarin die problemen worden verwoord zal verschillen. En zo kan volgens Kuhn worden verklaard waardoor ogenschijnlijk dezelfde ter- 
men uit verschillende theorieën een verschillende betekenis hebben: zij zijn incommensurabel.

Op deze manier heeft Kuhn het begrip 'incommensurabiliteit' ingebed in zijn theorie over kennisontwikkeling. De term verwijst echter ook naar een sociologisch verschijnsel, namelijk de door de wetenschapshistoricus aangetroffen communicatieproblemen tussen onderzoekers. Onderzoekers die in verschillende disciplinaire matrices werken hanteren hun eigen 'taal' en praten daardoor langs elkaar heen. De historicus treft onbegrip en misverstand aan, veroorzaakt door een gebrek aan overeenstemming over de vraag hoe het onderwerp van onderzoek moet worden verwoord. Aan deze sociologische gedaante van Kuhns incommensurabiliteitsthese kunnen richtlijnen voor empirisch onderzoek worden ontleend. Historisch onderzoek naar het verschijnsel incommensurabilteit zal zich primair moeten richten op het optreden van communicatieproblemen. Uit die communicatieproblemen zal dan vervolgens moeten worden afgeleid of er sprake is van incommensurabiliteit. Men kan dan natuurlijk niet volstaan met een beschrijving van de communicatieproblemen. De vraag of, en zo ja hoe, incommensurabiliteit optreedt kan alleen beantwoord worden als we precies de achtergronden van het debat kennen, uit welke disciplinaire matrices de debattanten komen, wat de maatgevende voorbeelden zijn. Dan pas kan besloten worden of er in het onderzochte geval sprake is van Kuhniaanse incommensurabiliteit. Dit bepaalt de route die wij in het volgende te gaan hebben. Ik zal eerst uitvoerig ingaan op de achtergronden van twee onderzoekstradities in de psychologie, om daarna een karakterisering te kunnen geven van twee disciplinaire matrices. Vervolgens zal ik de controversen over de betekenis van Kuo's onderzoek voor het aanlegomgeving vraagstuk in het door Kuhn ontwikkelde begrippenkader onderzoeken.

\section{3 \\ Achtergronden}

De situaties waarin de twee controversen over het onderzoek van Kuo plaatsvonden, moeten gezien worden in het licht van het behaviorisme van Watson en de ethologie van Lorenz. In de eerste helft van deze eeuw ontstonden deze stromingen als twee aparte takken van de wetenschap. Er zijn op zijn minst twee redenen aanwijsbaar waarom het behaviorisme en de ethologie als aparte disciplines zijn ontstaan. De eerste is alom bekend. Van oudsher staat in de psychologie de vraag centraal of het gedrag en de eigenschappen van mensen en dieren 
erfelijk zijn vastgelegd, of dat hun omgeving het karakter ervan bepaalt. Watson, de 'vader' van het behaviorisme, gaf een 'omgevingsantwoord' op deze vraag. Volgens hem komen dieren met een minimale erfelijke bagage ter wereld en is al hun gedrag aangeleerd. Lorenz, de 'vader' van de ethologie, heeft een "aanleg-antwoord" op deze vraag gegeven. Dieren beschikken volgens Lorenz over instincten die onderhevig zijn aan natuurlijke selectie. De tweede reden is veel minder bekend. In het behaviorisme en de ethologie werden twee verschillende methoden van empirisch onderzoek gebruikt die op specifieke wijze gekoppeld waren aan het antwoord op het aanleg-omgeving vraagstuk. Juist die koppeling geeft de twee onderzoekstradities hun eigen karakter.

1 Behaviorisme. Watsons behaviorisme komt voort uit de functionalistische dierpsychologie. ${ }^{4}$ In de tweede helft van de negentiende eeuw was de belangstelling voor het gedrag van dieren sterk toegenomen. Omdat de boom der soorten zich volgens Darwin heel geleidelijk heeft vertakt, vormde de evolutie van 'hogere' dieren uit 'lagere' dieren een keten, waarin geen enkele schakel ontbreekt. En aangezien ook psychische functies langs deze weg moesten zijn ontstaan, werd het interessant om ook op dit vlak de verschillen en overeenkomsten tussen mensen en dieren te onderzoeken. De evolutietheorie maakt het immers aannemelijk dat psychische functies al in een primitievere vorm bij dieren voorkomen. Problematisch is wel hoe men daar onderzoek naar kan doen, want het dierlijk bewustzijn is niet direct toegankelijk voor onderzoek. Twee benaderingen waren in de tweede helft van de negentiende eeuw populair. De eerste berust op antropomorfiseren. Men gebruikt dan menselijke belevingen om het gedrag van dieren te interpreteren door onze belevingen in het bewustzijn van dieren te projecteren. Experimentele toetsing is echter met deze methode nauwelijks mogelijk. In de tweede benadering wordt gekeken naar hoe het dier functioneert. Uit de reacties van dieren op bepaalde prikkels kunnen dierlijke functies worden afgeleid. Een voorbeeld van deze laatste methode is het bekende onderzoek van Pavlov. Pavlov bood een hond een tijdllang voedsel met een rinkelende bel aan. De response van de hond op deze prikkels bestond uit de afscheiding van speeksel. Na een bepaalde periode bood Pavlov alleen de rinkelende bel aan, die zo sterk geassocieerd was geraakt met de voedselprikkel, dat speekselafscheiding bleef optreden. Dat de hond twee prikkels met elkaar in verband brengt, leert ons dus wat over dierlijke functies. De onderzoeker hoeft niets te zeggen over de beleving van dieren.

Watsons behaviorisme vloeide rechtstreeks voort uit de experimentele traditie in de dierspychologie. Doordat de experimentele methode 
steeds belangrijker werd, verviel het antropomorfiseren: de objectieve methode van de experimentele dierspychologie nam haar plaats over. Het object van onderzoek kon volgens hem onderzocht worden in termen van stimulus (omgeving) en response (verandering in gedrag). Nadat het werk van Pavlov in de Verenigde Staten bekend werd kon Watson zijn ideeên preciseren. Uit Pavlows experimenten bleek dat een oorspronkelijk neutrale stimulus (de rinkelende bel), via associatie met een geconditioneerde stimulus (het voedsel), geassocieerd kon raken met een geconditioneerde response (speekselafscheiding zonder de aanwezigheid van voedsel). Het zogenaamd klassiek conditioneren was voor Watson een 'exemplar', dat liet zien hoe in de psychologie experimenteel onderzoek kon worden gedaan.

Als het behaviorisme van Watson louter in de traditie van de functionalistische dierpsychologie had gestaan, zou zijn behaviorisme weinig opzienbarend zijn geweest. Het behavioristisch manifest uit 1913 was echter schokkend omdat Watson veel verder ging. Daarin verdedigde hij dat niet alleen in de dierpsychologie, maar ook in de menselijke psychologie, elke referentie naar het bewustzijn gemist kon worden. Watson verweet de bewustzijnspsychologie een gebrek aan 'wetenschappelijkheid" en zag weinig heil in de introspectieve methode. De psychologie zou een volwaardige wetenschap kunnen worden door gebruik te maken van de experimentele methode. Net als in de natuurwetenschappen behoorden psychologen voorspellingen te leveren en dus moest naast het bewustzijn ook de introspectieve methode verdwijnen. Omdat Watson van mening was dat zowel het bewustzijn als de introspectieve methode in de psychologie niet thuishoorden, kreeg zijn behaviorisme een sterk periferalistisch karakter: de processen in het centrale zenuwstelsel waren van ondergeschikt belang. De werking van de omgeving was het belangrijkste verklaringsmechanisme. Watson werd in dit opzicht steeds radicaler. Vanaf 1924 ontkende hij zelfs dat er een genetische basis is voor gedragspatronen. 'We used to think that a lot of them were instinctive, that is "unlearned". But we are now almost at the point of throwing away the word "instinct", schreef Watson. ${ }^{5}$ Alle gedragspatronen werden in feite geleerd. Erfelijkheid door middel van genetisch overgedragen eigenschappen speelde volgens hem nauwelijks een rol en gold slechts voor morfologische structuren, zoals de bouw van zintuigen, spieren, ledematen, etcetera en verder voor enkele eenvoudige reflexen. Binnen de mogelijkheden van deze morfologische structuren had het dier volledige flexibiliteit om gedrag door het opdoen van ervaring met de buitenwereld te modelleren.

Watson presenteerde zijn behaviorisme als panacee tegen de kwalen van de bewustzijnspsychologie. Zijn middel had meteen al bijwerkingen: 
door gedrag in termen van stimulus-responsemechanismen te onderzoeken verdwenen niet alleen het bewustzijn en de introspectieve methode uit zijn behaviorisme, maar ook het instinctbegrip. ${ }^{6}$ Geheel onbedoeld waren deze bijwerkingen niet. Ten tijde van Watson verkeerde de instinctpsychologie in een diepe crisis. De instinctpsychologen hadden onderwijl wel 14.000 verschillende instincten gevonden maar gaven slechts tautologische verklaringen. Toen Lorenz, op aanraden van Karl Bühler, de werken van deze onderzoekers doornam, vond zelfs hij niets van zijn gading. De vader van de ethologie was diep teleurgesteld. Als zelfs aanlegdenkers weinig zien in de instincttheorieën van die tijd, hoeft het ons niet te verbazen dat voor een omgevingsdenker als Watson er goede redenen waren om de instincttheorie links te laten liggen.

2 Ethologie. ${ }^{7}$ De psychologie kon volgens Watson een natuurwetenschap worden wanneer zij gebruik zou maken van de experimentele methode. De vroege ethologen dachten hier anders over: niet de experimentele maar de beschrijvende, naturalistische methode kon volgens hen de dierpsychologie een wetenschappelijke grondslag geven. ${ }^{8}$ Nog sterker: de experimentele methode werd door de vroege ethologen veracht. Net zoals in de biologie, waar de experimentele en beschrijvende methode tot in de twintigste eeuw op gespannen voet met elkaar stonden, ${ }^{9}$ leidde ook hier het verschil in methode tot een scheiding der wegen.

De ethologie gaat terug op het werk van Darwin. ${ }^{10}$ In The Expression of Emotions in Man and Animals (1872) maakte Darwin vergelijkingen tussen het gedrag van dieren en mensen en probeerde hij aan te tonen dat de expressie van emoties bij verwante soorten overeenkomsten vertoont. De emoties, zo liet Darwin zien, kunnen bestudeerd worden door te kijken naar het gedrag van dieren, naar de gebaren en de gelaatsuitdrukkingen. Op deze wijze kunnen we iets leren over hun karakters. Retrospectief kunnen we zeggen dat Darwin niet de enige was die op deze wijze naar dieren keek. In de tweede helft was het onder naturalisten mode geworden om het gedrag van vogels te observeren. ${ }^{11}$ Omdat vogels net als mensen sterk visueel zijn ingesteld, zouden wij hun gedrag kunnen begrijpen. Naturalisten beschouwden vogels als emotionele dieren. Hierdoor vormden ze een geschikt onderzoeksobject om de expressie van emoties te bestuderen. De ethologen waren ervan overtuigd dat zij niet antropomorfiseerden, ondanks de schijn van het tegendeel. Zij ontleenden namelijk een krachtige analogieredering aan het pantomimespel. Dat pantomimespel was in de tweede helft van de negentiende eeuw een populaire theatervorm. De acteurs gebruiken alleen hun lichaam als expressie- en communicatiemiddel. Doelbewust laten ze het gebruik van hun stem achterwege. De toeschouwer moet de 
emoties aan de bewegingen en de gebaren herkennen. De vroege ethologen interpreteerden het gedrag van dieren analoog aan het pantomimespel. Dieren waren volgens hen acteurs in hun eigen omgeving, zij vertonen rituelen en ceremoniën; tijdens de balts bijvoorbeeld. Een etholoog kan die rituelen en ceremoniën begrijpen door de gebaren en de gelaatsuitdrukkingen te beschrijven. Op deze wijze onderzochten de ethologen het aangeboren karakter van dieren.

De beschrijvende methode werd in de eerste jaren van de ethologie gepreciseerd tot de causaal-analytische methode. ${ }^{12}$ Hiermee wordt het volgende bedoeld. De gebaren en gelaatsuitdrukkingen van dieren kan men steeds verfijnder beschrijven en analyseren in termen van spiercontracties of reflexbewegingen. Vervolgens kunnen instincten, motivaties gepostuleerd worden die de patronen in het gedrag veroorzaken. $\mathrm{Na}$ anallyse van de objectieve beschrijving proberen ethologen in een neutrale terminologie (instincten e.d.) de onderliggende causale mechanismen te bestuderen. Uiteindelijk vertaalde men de aangeboren instincten in meurofysiologische termen. Op deze manier werd het dierlijk bewrustzijn geëlimineerd.

Met behulp van de beschrijvende methode ontdekte Lorenz dat bepaalde gedragspatronen een vaste vorm hebben. Vogels beschikken over soortspecifieke gedragspatronen, die op dezelfde wijze de soort karakteriseren als dat het geval is met morfologische structuren. Hiermee is het belangrijkste verschil met de oudere instinctpsychologie weergegeven. In de instinctpsychologie van bijvoorbeeld McDougall werden instincten beschouwd als globale categorieën: met het ouderlijke instinct verklaarde hij het gehele repertoire van gedragingen die ouders vertonen tijdens de opvoeding. Lorenz daarentegen bestudeerde elk gedragspatroon afzonderlijk. Lag bij McDougall de nadruk op de instincten, bij Lorenz komen die pas na analyse van de afzonderlijke gedragspatronen in het vizier. De ontdekkingen van Lorenz hangen ook met deze manier van werken samen. Hij vond bijvoorbeeld dat organismen op een soortspecifieke wijze reageren op uitwendige prikkels. Bepaalde prikkels uit de omgeving bleken een soortspecifiek gedragspatroon op te wekken. Een bekend voorbeeld is de soortspecifieke reactie van het mannetje van de driedoornige stekelbaars om bij de verdediging van zijn territorium bewegende objecten aan te vallen, die aan de onderzijde rood zijn gekleurd. De speciale gevoeligheid voor rood is functioneel, aangezien de territoriumverdediging vooral gemunt is op mannelijke soortgenoten en deze in het voorjaar van onderen rood zijn gekleurd. Op grond van vele waarnemingen meende Lorenz dat zowel aan de sensorische zijde als aan de motorische zijde georganiseerde patronen te onderkennen zijn. Organismen reageren op soortspeci- 
fieke wijze op uitwendige prikkels (de rode onderzijde) met een soortspecifiek aangeboren gedragspatroon (het aanvallen van een mannelijke soortgenoot). Lorenz en Tinbergen noemen dit mechanisme later het 'innate releasing mechanism'.

Het soortspecifieke karakter van gedrag staat centraal in de ethologische theorie van Lorenz. De beschrijvende methode stelde hem in staat gedragspatronen binnen de soort en tussen soorten te vergelijken. Het vergelijken van gedragspatronen tussen verwante soorten is biologisch gezien interessant. Als gedragspatronen net als morfologische structuren een vaste vorm bezitten, zijn ze namelijk fylogenetisch te verklaren. Het homologieconcept wordt toepasbaar op gedrag. Natuurlijk is Lorenz niet van mening dat dieren niets zouden leren. Hij is van mening dat gedrag uit aangeboren, dat wil zeggen genetisch bepaalde elementen en aangeleerde elementen is opgebouwd. De ontwikkeling van gedrag ziet Loren $z$ als een proces waarbij de aangeboren en aangeleerde elementen geleidelijk aan elkaar geschakeld worden ("InstinktDressur Verschränkung').

\section{4 \\ Twee disciplinaire matrices}

Wanneer we het optreden van incommensurabiliteit in de psychologie willen onderzoeken, dan kunnen we niet volstaan met een beschrijving van twee onderzoekstradities. De beschrijving moet verder gepreciseerd worden in een Kuhniaanse terminologie, dat wil zeggen dat we de onderzoekstradities moeten karakteriseren in termen van disciplinaire matrices. Voor de karakterisering van de disciplinaire matrices heb ik het onderzoek van Watson (1913-1925) en het vroege werk van Lorenz (1927-1942) als uitgangspunt genomen. ${ }^{13}$

1 Theoretische basisschema's. Centraal in het behaviorisme van Watson staat de veronderstelling dat dieren gedragselementen leren. De omgeving is de belangrijkste oorzaak voor gedrag. Erfelijkheid speelt volgens Watson nauwelijks een rol en geldt slechts voor morfologische structuren en enkele eenvoudige reflexen. Binnen de mogelijkheden van deze morfologische structuren heeft het dier volledige flexibiliteit om gedrag door het opdoen van ervaring met de buitenwereld te modelleren. De conditioneringswetten zijn de belangrijkste verklarende wetten. Centraal in de ethologie van Lorenz staat de gedachte dat gedrag wit genetisch bepaalde elementen en aangeleerde elementen is opgebouwd. De genetisch bepaalde elementen zijn onderhevig aan de wetten van Mendel 
en kunnen evolutionair verklaard worden met de theorie van Darwin. Was Watson impliciet van mening dat gedrag willekeurig modificeerbrar is, zo is Lorenz impliciet van mening dat een deel van het gedrag genetisch is bepaald. Dat deel is door rijping van het zenuw-spiersysteem ontstaan. Dit rijpingsproces is volgens Lorenz een volledig endogeen proces

2 Methoden van onderzoek. Behavioristen en ethologen maken gebruik van een inductieve onderzoeksstijl. Ethologen gebruiken voornamelijk de evolutietheorie voor het formuleren van puzzels. Voor het behaviorisme is het minder duidelijk welke geaccepteerde theorie als fonds wordt gebruikt voor het formuleren van hypothesen. Voor een deel gaat het om kennis uit de fysiologie en ideeën uit de associatiepsychologie die worden 'vertaald' naar diergedrag. Opvallend zujjn in ieder geval de structurele gelijkenissen tussen de associatiewetten en de behavioristische wetten.

Een belangrijk verschil tussen de behavioristische en de ethologische methode komt voort uit hun respectievelijk experimentele en naturalistische achtergrond. Behavioristen onderzoeken leerprocessen door middel van experimenteel onderzoek, terwijl ethologen beschrijvend te werk gaan en daarbij gebruik maken van morfologische en taxonomische technieken. Uiteraard is dit onderscheid niet absoluut maar relatief bedoeld: de hoofdmoot van het ethologisch en behavioristisch onderzoek is respectievelijk beschrijvend en experimenteel.

3 Normen en waarden. Onder normen en waarden worden hier verstaan de algemene criteria die gebruikt worden bij het doen en beoordelen van onderzoek. Zowel in het behaviorisme als in de ethologie probeert men de kleinste bouwstenen van het gedrag te vinden, doet men kwantitatief onderzoek, probeert men mechanismen in het gedrag bloot te leggen en gaat men daarbij empirisch te werk. De verschillen hangen samen met de achtergronden van de twee tradities. Voor de naturalistisch ingestelde ethologen is gedrag dat wat in de natuurlijke situatie wordt vertoond. Vanwege de experimentele achtergrond zijn behavioristen vooral geïnteresseerd in dierlijke functies. Het gedrag wordt door hen voornamelijk in het laboratorium onderzocht.

4 Maatgevende voorbeelden. Voor het behaviorisme is het stimulus-responsemechanisme het centrale element in het maatgevend voorbeeld. Doordat een student zich de theorie via dit mechanisme eigen maakt, leert hij zien welk soort problemen hanteerbaar zijn voor de theorie. 
Het theoretisch basisschema van bijwoorbeeld klassiek conditioneren wordt in leerboeken als volgt weergegeven:

$\begin{array}{lll}\text { CS }-7 & & \text { CS: Conditioned stimulus } \\ \text { US } \longrightarrow \text { UR } & \text { CS } \cdots . .- \text { CR } & \text { US: Unconditioned stimulus } \\ \text { tijdens } & \text { na } & \text { UR: Unconditioned response } \\ \text { conditionering } & \text { conditionering } & \text { CR: Conditioned response }\end{array}$

Het plaatje laat zien hoe de formatie van een nieuwe associatie tussen een geconditioneerde stimulus en een response geschiedt. Via SR-mechanismen leert een student de concrete probleemoplossingen van de theoretische basisschema's. Door middel van experimenten zal hij nagaan hoe stimuli uit de omgeving te lokaliseren zijn, hoe die stimuli met andere stimuli zijn geassocieerd, welke effecten stimuli op gedrag hebben, etcetera. Voor zijn experimenten heeft een student maar eén dier nodig, omdat de conditioneringswetten op alle dieren van toepassing zijn.

Voor de ethologie is het ethogram (een classificatiesysteem voor gedrag) het centrale element van het maatgevend voorbeeld. Via het ethogram leert een student dieren observeren, de eenheden in het gedrag onderkennen, beschrijven en ordenen. In een leerboek treft men vaak de volgende illustratie aan, die aangeeft hoe gedrag georganiseerd is:

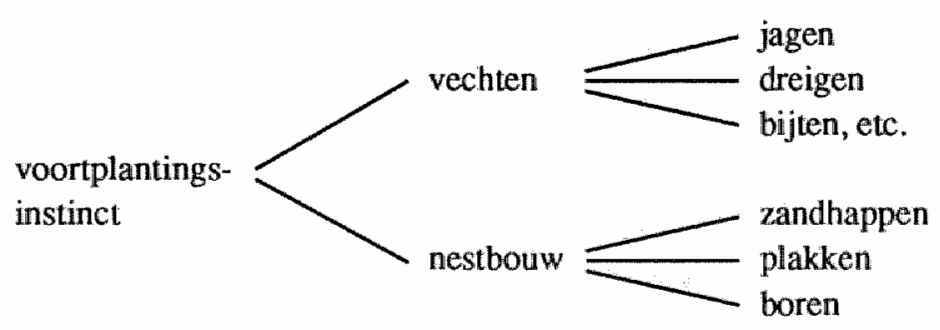

groeperingen

gedragselementen

Door het gedrag van dieren te vergelijken zal een student zien welke gedragspatronen typisch voor de soort zijn, wat de instinctieve gedragspatronen zijn, hoe die gedragspatronen evolutionair verklaard kunnen worden, etcetera. Voor zijn beschrijvend onderzock heeft een student veel dieren nodig, omdat de aangeboren gedragspatronen pas na wergelijkend onderzoek zichtbaar worden. 
Door deze preciezere karakterisering van de twee disciplinaire matrices kan nu aangegeven worden waar we kunnen verwachten dat de disciplinaire matrices incommensurabel zijn. Omdat een behaviorist via stimulus-responsemechanismen de concrete probleem oplossingen leert van de theoretische basisschema's (bij Kuhn zijn dit de symbolische generalisaties) en een etholoog via het ethogram, kan incommensurabiliteit optreden wanneer behavioristen en ethologen het ontstaan van soortspecifieke gedragspatronen verklaren. Het ontstaan van een soortspecifiek gedragspatroon zal door behavioristen verklaard worden door stimulus-responsemechanismen, terwijl een etholoog op basis van beschrijvend onderzoek tot de conclusie kan komen dat zo'n gedragspatroon instinctief is. Om deze reden staat in het vervolg een soortspecifiek gedragspatroon centraal: het pikgedrag van een kuiken.

\section{5 \\ Het onderzoek van Kuo ${ }^{14}$}

Volgens Mackenzie is het behaviorisme sterk methodisch georiënteerd geweest. ${ }^{15}$ Door gedrag in plaats van bewustzijn als object van onderzoek te kiezen, konden volgens Watson de methoden van de natuurwetenschappen gevolgd worden. Deze methodische oriëntatic werd door de verschillende varianten die na Watson zijn ontstaan gedeeld. De theorie van Kuo is daarop geen uitzondering. Wanneer Kuo eind jaren twintig een variant op het behaviorisme van Watson verzint, is de methodische inslag duidelijk herkenbaar. Zijn theorie is een poging om het laatste stukje metafysica uit het behaviorisme van Watson te snijden. Niettemin speelden hierbij ook inhoudelijke overwegingen een rol. Kuo's belangstelling verschoof in de jaren twintig naar de ontwikkeling van gedrag en juist voor het bestuderen van de ontwikkeling van gedrag waren volgens Kuo de theoretische termen in de theorie van Watson ongeschikt. Omdat deze veranderingen in zijn ideeën direct voorafgaan aan zijn gedragsembryologisch onderzoek, zal ik Kuo's argumentatie kort samenvatten.

In 1921 publiceerde Zing-Yang Kuo zijn eerste artikel onder de titel: 'Giving up instincts in psychology'. Hiermee sloot hij zich aan bij de zogenaamde 'anti-heredity movement' in de Verenigde Staten. Instincten waren volgens Kuo in feite geleerde gewoonten. ${ }^{16}$ Door deze provocerende stelling bleef Kuo's entree in de wetenschappelijke wereld niet onopgemerkt. Zijn artikel, zo constateerde Kuo achteraf tevreden, ontketende een storm van protesten. Kuo werd van meet af aan een van de meest besproken auteurs in het 'instinct-habit'-debat. De storm van 
kritiek liet Kuo niet onopgemerkt aan zich voorbijgaan: hij herzag zijn standpunt en veranderde een aantal theoretische vooronderstellin. gen. $^{17}$

In de eerste plaats is de stelling, dat instincten in feite geleerde gewoonten zijn, volgens Kuo misleidend. Die vooronderstelt namelijk dat er een scherp onderscheid bestaat tussen geleerde en niet-geleerde gedragingen. Dat onderscheid is volgens Kuo bijzonder problematisch. Hij trekt daarom een andere mogelijke conclusie: zowel het instinctbegrip als het gewoontebegrip deugen niet. Deze conclusie verbindt Kuo met een inhoudelijke overweging. De concepten 'instinct', 'gewoonte' en 'leren' zijn ongeschikt om de ontwikkeling van het gedrag te verklaren. Kuo liet dus een vooronderstelling van Watson vallen. Watson was immers van mening dat gedrag door leerprocessen ontstaat. Kuo's verwerping van de theoretische termen in Watsons theorie heeft ook consequenties voor het stimulus-responsemechanisme. Omdat Kuo de termen 'gewoonte' en 'leren' uit Watsons vocabulair schrapt, heeft het stimulus-responsemechanisme geen betrekking meer op leerprocessen. Daardoor wordt het stimulus-responsemechanisme in Kuo's theorie een lege huls: alleen de termen stimulus en response blijven over om de invloed van de omgeving op gedrag te bestuderen. Kuo's theorie krijgt hierdoor een extreem periferalistisch karakter. Een psycholoog heeft volgens hem de taak de invloed van omgevingsfactoren op gedrag te onderzoeken, door na te gaan hoe en welke stimuli gedrag veroorzaken. Net als Watson, blijft Kuo denken dat erfelijkheid slechts geldt voor morfologische structuren en enkele eenvoudige reflexen. ${ }^{18}$

Deze wijzigingen in Watson's behaviorisme -die duidelijk door het positivisme geïnspireerd zijn- vormen de achtergrond waartegen Kuo's onderzoek naar de gedragsontwikkeling van kippeëmbryo's geplaatst moet worden. Vanaf 1932 produceerde Kuo een gestadige stroom artikelen over de ontwikkeling van kippeëmbryo's waarin hij onder meer invloed van omgevingsfactoren op de bewegingen beschrijft. Zijn onderzoek wordt achteraf om drie redenen origineel gevonden. Ten eerste vanwege een methodische innovatie: door een venstertje in de schaal van een kippeëi te knippen kon Kuo de bewegingen van het embryo waarnemen en beschrijven. Ten tweede vanwege de precieze beschrijvingen van de bewegingen van het embryo die hierdoor mogelijk werden. En ten derde omdat hij voor het eerst de invloed van omgevingsfactoren op de bewegingen van het embryo beschrijft en daar bovendien experimenteel onderzoek naar heeft gedaan.

Omdat het ondoenlijk is een allesomvattend overzicht van Kuo's onderzoek te geven, bespreek ik een tweetal voorbeelden waar later veel over gedebatteerd is. Volgens Kuo beinvloeden stimuli uit de omgeving 
van het embryo de bewegingen van het embryo. Hij zag bijwoorbeeld dat de kop van het embryo in een bepalalde fase van de ontwikkeling. opgetild werd door de hartslag. De hartslag vatte Kuo op als stimulus uit de omgeving. Een tweede voorbeeld: het amnion, dat het embryo omhult en gladde spieren bevat die niet met het zenuwstelsel van het embryo verbonden zijn, contraheert in bepaalde stadia van de ontwikkeling waardoor het embryo schommelende bewegingen maakt. Nadat Kuo dit geobserveerd had voerde hij een experiment uit. Hij verwijderde het amnion en nam waar dat er een afname optrad in de bewegingen. Hieruit concludeerde Kuo dat amnioncontracties dienst doen als stimuli voor actieve bewegingen.

Op het eerste gezicht lijken deze twee voorbeelden weinig te behelzen: het betreft onschuldige beschrijvingen en een eenvoudig experiment. Het tegendeel is echter het geval. Kuo's onderzoek is een belangrijke bijdrage geweest aan de embryologie en de vergelijkende psychologie. Dat wordt duidelijk wanneer we ingaan op de stand van zaken in het veld van onderzoek rond 1930. In de embryologie heeft Kuo voor psychologen een nieuw onderzoeksterrein blootgelegd. Er waren tot dan toe wel suggesties in die richting gedaan, maar empirisch onderzoek was er niet verricht. Kuo liet met zijn onderzoek zien dat psychologen niet alleen postnataal, maar ook prenataal de invloed van omgevingsfactoren op gedrag kunnen onderzoeken. Daarmee had hij een alternatief gegeven voor het neurofysiologisch onderzoek van biologen die zich uitsluitend bezighielden met de rijping van het zenuw-spiersysteem. Er is nog een tweede reden waarom Kuo's werk voor de psychologie belangwekkend is. Kuo meende namelijk aangetoond te hebben dat er een continuilteit is tussen prenataal en postnataal gedrag. Deze constatering heeft belangrijke consequenties voor het aanleg-omgeving vraagstuk. Als er een continuiteit is tussen prenataal en postnataal gedrag, dan is het immers niet zonder meer zeker dat men door middel van postnataal onderzoek het aanleg-omgeving vraagstuk kan oplossen. Prenataal kunnen stimuli uit de omgeving bijvoorbeeld de ontwikkeling van gedrag beinvloeden die met postnataal onderzoek nooit worden gevonden. Deze suggestie van Kuo trok de aandacht van een aantal psychologen. ${ }^{19} \mathrm{Zij}$ beseften dat hier een interessante mogelijkheid lag om het oude aanleg-omgevingsvraagstuk een nieuwe wending te geven. Wanneer Tinbergen in 1947 de grote oversteek maakt om de ethologie in de Verenigde Staten te verbreiden, wordt die mogelijkheid door Schneirla en Lehrman direct uitgewerkt. Zij gebruiken het onderzoek van Kuo om de ethologische visie op instinctief gedrag te kritiseren. 


\section{6}

\section{De eerste controverse}

Wanneer Kuo's onderzoek na 1953 het onderwerp wordt van een debat tussen Amerikaanse psychologen en Westeuropese ethologen, is het behaviorisme al over haar hoogtepunt heen. Het behaviorisme wordt in de psychologie vanaf de jaren vijftig verdrongen door de cognitieve psychologie: $\mathrm{Er}$ is dan echter inmiddels een 'nieuwe" traditie uit het behaviorisme voortgekomen: de vergelijkende en fysiologische psychologie. Het zijn vertegenwoordigers van deze laatste traditie die de theoretische veronderstellingen van de ethologie met behulp van Kuo's onderzoek onder vuur hebben genomen.

Zoals gezegd heeft de vergelijkende psychologie haar wortels in het behaviorisme. De belangstelling van de onderzoekers ging in eerste instantie uit naar leerprocessen bij dieren. Het instinctbegrip werd door hen 'onwetenschappelijk' genoemd en was volgens hen onbruikbaar voor onderzoek naar diergedrag. Dit had twee consequenties. Ten eerste werd er daardoor nauwelijks vergelijkend onderzoek verricht, zoals de ethologen dat deden, en ten tweede stonden daardoor alle schijnwerpers gericht op de rat. ${ }^{20}$ Lorenz kon dan ook in 1950 cynisch opmerken dat belangrijkste publikaties op het terrein van diergedrag in de Verenigde Staten in 'The Journal of Comparative Psychology' verschenen, maar dat dat gewoon de resultaten van behavioristisch onderzoek waren. ${ }^{21}$ De titel van het tijdschrift was de schaapsvacht van de wolf: het radicaal omgevingsdenken. Voor de kleine kring van vergelijkende psychologen gaat deze kritiek in 1950 echter niet meer op. Vooral door toedoen van Schneirla is de vergelijkende psychologie dan al op belangrijke punten veranderd. Hij was van mening dat de dichotomieën tussen aangeboren-aangeleerd, rijping-leren, ongeschikt zijn voor experimenteel onderzoek in de psychologie. Deze gedachte werkte hij verder uit door het begrip 'leren' op te rekken. Schneirla pleitte voor het begrip 'ervaring', en verstond daaronder alle, mogelijke interne en externe factoren die gedrag beïnvloeden. Met dit begrip kon hij de traditionele dichotomische denkwijze vermijden. Er kleeft wel een bezwaar aan deze nieuwe gedachtengang: het begrippenkader wordt door het oprekken van het begrip 'leren' veel te ruim. De precisie die bijvoorbeeld verbonden is met het begrip 'conditionering' gaat hiermee verloren. Schneirla ziet zich dan ook gedwongen het begrip 'ervaring' meer inhoud te geven en dat blijkt geen eenvoudige opgave. Het empirisch onderzoek blijft dan ook achter bij de theoretische ontwikkeling. En wanneer Schneirla en Lehrman in 1953 kritiek leveren op de ethologische theorie, hebben 
zij geen eigen empirisch materiaal om hun theoretische kritiek te illustreren. Daarom schuiven zij het onderzoek van Kuo naar de frontlinie.

Lehrman en Schneirla bestrijden de impliciete veronderstelling in de theorie wan Lorenz, namelijk de gedachte dat aangeboren gedragspatronen door rijping ontstaan. ${ }^{22} \mathrm{Zij}$ leiden die impliciete veronderstelling af uit de redenering van ethologen dat op basis van beschrijvend onderzoek uitgemaakt kon worden wanneer een gedragspatroon aangeboren is. Maar aan de hand van Kuo's onderzoek menen Lehrman en Schneirla aan te kunnen tonen dat deze veronderstelling onjuist is. ${ }^{23} \mathrm{Zij}$ nemen het pikgedrag van een kuiken als voorbeeld. Al sinds lange tijd is bekend dat kuikens, spoedig nadat zij uit het ei zijn gekomen, naar objecten pikken, schrijft Lehrman. Dit pikgedrag voldoet aan de criteria die ethologen voor aangeboren gedragspatronen hebben gesteld: het is soortspecifiek, wordt door geïsoleerd opgegroeide individuen vertoond, bestaat uit stereotiepe elementen en ontwikkelt zich zelfs wanneer pas uitgekomen kuikens het gedragselement niet oefenen. Het zou dus een voorbeeld zijn van een instinctief gedragspatroon. Het onderzoek van Kuo laat volgens Lehrman zien dat dit niet het geval hoeft te zijn. Kuo heeft namelijk beschreven dat een aantal stereotiepe elementen van het pikgedrag een prenatale oorsprong hebben: ze worden al in het ei door het embryo vertoond. Bovendien heeft Kuo beschreven dat actieve kopbewegingen zich lijken te ontwikkelen als gevolg van tactiele stimulatie. Bijvoorbeeld: de kop van een embryo wordt eerst een tijdlang opgetild door de hartslag, waarna de actieve kopbewegingen beginnen. De tactiele stimulatie zou een rol kunnen spelen in de ontwikkeling van de actieve kopbewegingen. Lehrman concludeert vervolgens: 'Kuo's observations strongly suggest several interpretations of the development of pecking (which, of course, are subject to further clarification); ${ }^{24} \mathrm{Op}$ basis van deze gegevens, maar ook andere, kritiseert Lehrman de theoretische veronderstellingen van de ethologische theorie. Ethologen gaan volgens hem uit van een dichotomie tussen aangeboren en aangeleerd die in de ontwikkeling van gedrag niet houdbaar is. Omdat in de ontwikkeling van gedragingen zowel rijpingsprocessen als ervaring een rol spelen, heeft het geen zin om over aangeboren gedragspatronen te spreken. Ook verwante theoretische concepten, zoals het 'innate releasing mechanism' en de 'Instinkt-Dressur Verschränkung' zijn volgens Lehrman om dezelfde reden onhoudbaar.

De kritiek van Lehrman (maar ook die van Hebb, Schneirla, e.a.) heeft tot een scheuring in de ethologie geleid. De Duitstalige ethologen handhaafden in eerste instantie de oude ethologische terminologie terwijl de Nederlandse en Engelse ethologen zich lieten 'bekeren'. 
Een paar voorbeelden kunnen de reacties van de twee kringen op de kritiek van Lehrman illustreren.

Lorenz is de belangrijkste woordwoerder van de Duitstalige ethologen geweest. Niet alleen omdat de kritiek op hem gericht was, maar ook omdat hij de onbetwiste leider was van de ethologen-kring te Seewiesen. Lorenz handhaafde de ethologische veronderstellingen en vond het onwaarschijnlijk dat de theorie van Lehrman juist zou zijn. Hij gaf bovendien twee argumenten die de theorie van Lehrman zouden tegenspreken. ${ }^{26}$ Ten eerste kan Lehrman volgens Lorenz niet verkllaren waarom de actieve kopbeweging, die door individuen wordt geleerd als gevolg van de voorafgaande tactiele prikkeling (de hartslag), aangepast is aan de eetsituatie na het uitkomen. Ten tweede blijft het volgens Lorenz volkomen duister waarom alleen sommige vogels pikken na het uitkomen, zoals kippen, terwijl bijvoorbeeld roestvogels sperren, eenden lebberen en duiven hun snavel in de bek van hun ouders schuiven, terwijl bij alle dieren in de embryonale fase de kop op dezelfde wijze opgetild wordt door de hartslag! Deze argumenten werden door Lorenz en zijn leerlingen in de discussies met Lehrman c.s. gebruikt. En wanneer dat tot een directe confrontatie leidde, ontstonden er communicatieproblemen. Een mooi voorbeeld is een discussie tussen Eibl-Eibesfeldt, een leerling van Lorenz, en Hebb, een opponent van de ethologie. Op een congres ging Hebb een debat aan met Eibl-Eibesfeldt: Eibl-Eibesfeldt zou Lehrman niet begrepen hebben. Eibl-Eibesfeldt diende hem van antwoord:

'... Our opponents express the opinion that this behaviour was learned within the egg'.

Hebb: 'No'.

Eibl-Eibesfeldt: 'Yes they do. Concluding from this and similar experiments they say there is no innate motor pattern: everything is learned'.

Hebb: 'There is no support for that extreme view. My disagreement is with the dichotomy you made earlier, between learned behaviour and instinctive behaviour?. ${ }^{27}$

Dit fragment uit een veel langere discussie over theoretische veronderstellingen laat goed zien waar de verschillen in opvattingen liggen. Lehrman c.s. waren van mening dat het onderzoek van Kuo liet zien dat de dichotomie tussen rijping en leren in de ontwikkeling van gedrag onhoudbaar is. Lorenz c.s. daarentegen dachten dat Lehrman het had over een leerproces: zij gingen juist uit van die dichotomie. Bijgevolg verweten zij Lehrman dat hij van mening zou zijn dat kippen het 
pikgedrag in het ei leerden. Lehrman kreeg dit werwijt zo vaak te horen, dat hij aan zijn eigen woor den ging twijfelen: "... I almost came to believe that II had said it! ${ }^{28}$ Uit deze communicatieproblemen kunnen we afleiden dat de inhoud van term 'leren' verschilt in de theorieën van Lorenz en Lehrman. De term 'leren' staat bij Lehrman niet meer tegenover de term 'instinctief'. En, omdat Lehrman de impliciete veronderstelling in de theorie van Lorenz kritiseerde (instinctieve gedragingen ontstaan door rijping), staat de term 'leren' ook niet meer tegenover 'rijping'. 'The understanding provided by Kuo's observations owes nothing to the "maturation-versus-learning" formulation', schrijft Lehrman. ${ }^{29}$ Bij Lorenz staat de term 'leren' juist wel tegenover de term 'instinctief, en -vanwege de impliciete veronderstelling- ook tegenover de term 'rijping'. Zelfs wanneer we de enige concessie erbij betrekken die Lorenz naar aanleiding van de kritiek doet, blijven de verschillen bestaan. Lorenz heeft toegegeven dat strikt genomen de termen 'aangeboren' en 'aangeleerd' niet toepasbaar zijn op gedragspatronen, omdat genetische factoren en omgevingsfactoren nu eenmaal in ieder biologisch produkt doorwerken. Maar, zo stelt Lorenz, ze zijn wel toepasbaar op een bepaalde eigenschap van gedrag, namelijk de aangepastheid van gedrag. Deze eigenschap van gedrag is in het behavioristisch denken volgens Lorenz verwaarloosd. Aangepastheid betekent volgens Lorenz dat een dier op twee wijzen informatie over de omgeving heeft verkregen: of door evolutie, en in dat geval is de informatie in de genen vastgelegd; of door individuele interactie van het dier met zijn omgeving. Op deze wijze is het volgens Lorenz gewettigd om de dichotomie te handhaven. Het verschil met Lehrman is weer direct duidelijk: hij gaat er juist van uit dat iedere aangepastheid tot stand komt onder invloed van evolutionaire én ontogenetische factoren.

Het feit dat de term 'leren' een andere betekenis had en aanleiding gaf tot communicatieproblemen, hangt samen met de tegenstelling tussen contraire en subcontraire begrippenparen. ${ }^{30}$ Logisch gezien was voor Lehrman het begrippenpaar 'rijpen' en 'leren' een subcontrair begrippenpaar. Dat wil zeggen dat de begrippen betrekking hebben op functionele verbanden: ze kunnen in een dimensie geordend worden. Verschillen in het gedrag van een individu kunnen, volgens Lehrman, op verschillende tijdstippen verklaard worden door genetische factoren (rijping) of omgevingsfactoren (leren, ervaring), of beide. De nadruk lag bij Lehrman op de ontwikkeling van gedrag. Lorenz daarentegen hanteerde de logica van contraire begrippen: bij hem stond het begrip 'instinctief tegenover het begrip 'aangeleerd' (preciezer: 'geconditioneerd'). Een gedragspatroon is of instinctief of aangeleerd, en, impliciet, of door rijping of door leerprocessen ontstaan. 
Betekent dit nu ook dat de theorieën van Lehrman en Lorenz inconmensurabel zijn? Hoewel de logische analyse dit lijkt te suggereren, zijn er argumenten te geven voor het tegendeel. De logische analyse maskeert namelijk dat aan de benaderingen van Lorenz en Lehrman verschillende problemen ten grondslag liggen. Zoals ook Lehrman later heeft beargumenteerd, bestudeert Lorenz gedrag vanuit een evolutionair perspectief en is daarom niet geïnteresseerd in ontogenetische vragen. Het ging Lorenz niet om de vraag hoe interne en externe factoren een bijdrage leveren aan de ontwikkeling van gedrag. Lorenz omschreef zijn vraagstelling als volgt:

'Not being experimental embryologists but students of behavior, we begin our query, not at the beginning of the growth, but at the beginning of the function of such innate mechanisms. ${ }^{, 31}$

Deze benadering is eerder gericht op evolutionaire dan op ontogenetische vragen. Het gaat Lorenz om de 'uiteindelijke factoren' die in de loop van de evolutie de aangepastheid van gedrag hebben bewerkstelligd en om de rol die deze factoren spelen tijdens de ontogenie. Maar dan is ook begrijpelijk waarom Lorenz vasthoudt aan de oudere dichotomie, zoals ook Lehrman heeft opgemerkt:

'As Lorenz states, he is really not interested in the origins of behaviour patterns at those stages of development before they begin to exist as modes of adaptation to the environment. Since his interest starts at that point, it is quite understandable that the only kind of experience that would seem theoretically relevant for him would be the kind of conditioning and associative learning characterististic of animals whose behavioral organization is already ontogenetically well formed. ${ }^{32}$

Lorenz en Lehrman begrijpen elkaar kortom wel, maar zijn geïnteresseerd in verschillende problemen. De kritiek van Lehrman blijft natuurlijk wel van toepassing. Voor de bestudering van de ontogenie van gedrag is Lorenz's begrippenkader volgens Lehrman heuristisch niet interessant, omdat de ontogenie van gedrag in zijn benadering eigenlijk niet aan de orde komt.

Dit laatste kan aan de hand van een voorbeeld worden uitgewerkt. Volgens Lorenz dient ontogenetisch onderzoek zich te richten op de vraag of de aangepastheid van gedrag tot stand komt of door evolutionele factoren of door individuele interactie van het dier met zijn omgeving. Dat zouden we kunnen bepalen door in een deprivatie-experiment na te gaan of (vermeend) aangeboren gedrag zich ontwikkelt zelfs 
indien de factoren waaraan het gedrag is aangepast zijn geellimineerd. Wanneer het gedrag zich toch ontwikkelt, dan is het wolgens Lorenz 'aangeboren'. Deze conclusie is volgens Lehrman en anderen echter onjuist: uit het feit dat de factoren waaraan het gedrag is aangepast geen rol spelen bij de ontwikkeling van het gedrag, volgt alleen dat zij niet van invloed waren. De vraag of omgevingsfactoren al eerder tijdens de ontogenie een roll hebben gespeeld is hiermee nog niet beantwoord. ${ }^{33}$

Deze kritiek van Lehrman op Lorenz werd door met name Nederlandse en Engelse ethologen onderschreven. $\mathrm{Zij}$ gaven toe dat de oudere ethologische ideeën onbruikbaar waren om de ontogenie van gedrag te onderzoeken. Tot welke inhoudelijke wijzigingen deze 'bekering' leidde zal ik aan de hand van een paar voorbeelden bespreken.

Lorenz had twee bezwaren aangevoerd tegen Lehrmans interpretatie van Kuo's onderzoek. Ten eerste kon Lehrman volgens Lorenz niet verklaren waarom er verschillen in pikgedrag zijn tussen soorten, hoewel bij al die soorten de kop in de embryonale fase werd opgetild door de hartslag. Ten tweede kon Lehrman volgens Lorenz niet verklaren waarom het door individuen 'geleerde' pikgedrag aangepast is aan de specifieke eetsituatie na het uitkomen. Beide bezwaren zijn door 'bekeerde' ethologen bekritiseerd. Hinde wond het eerste bezwaar van Lorenz ridikuul. ${ }^{34}$ Verschillen tussen kippen, eenden, etcetera kunnen volgens hem wel genetisch zijn bepaald, maar dat neemt niet weg dat dezelfde omgevingsfactoren (de hartslag) de decodering van de informatie, die vastgelegd is in de genen, kunnen beinvloeden. Verschillende genotypen kunnen op verschillende wijze ontvankelijk zijn voor dezelfde factor uit de omgeving. Daarom doet het bezwaar van Lorenz volgens Hinde niet ter zake. Tinbergen heeft het tweede bezwaar van Lorenz bekritiseerd. ${ }^{35}$ Omdat Lorenz volgens Tinbergen uitsluitend oog heeft voor de door de evolutie ingebrachte orde in het gedrag, ziet hij over het hoofd dat er nog een andere mogelijkheid is. Wanneer iedere aangepastheid tot stand komt onder invloed van evolutionele én ontogenetische factoren, dan wordt het voor psychologen en ethologen interessant om na te gaan hoe ontwikkelingsstrategieën verklaard kunnen worden als aanpassingen aan een bepaalde sociale en oecologische nis. Bijvoorbeeld door verschillen in ontwikkelingsstrategieën tussen verwante soorten te vergelijken. Daarom is het bezwaar van Lorenz niet terecht. Het probleem is niet hoe Lehrman kan verklaren hoe het individueel 'geleerde' pikgedrag aangepast is aan de specifieke eetsituatie, maar hoe de ontwikkelingsstrategie, waarin de tactiele stimulatie een rol kan spelen, als aanpassing verklaard kan worden.

Hinde en Tinbergen hebben het niet alleen bij kritiek op Lorenz gelaten. Geheel consequent hebben zij ook belangrijke wijzigingen in 
de ethologische theorie aangebracht. Zo spraken zij niet meer over 'aangeboren gedragspatronen' maar over 'gedragspatronen', en niet over 'innate releasing mechanism' maar over 'releasing mechanism' en schrapten zij de term 'Instinkt-Dressur Verschränkung'. Deze wijzigingen stemden Lehrman uiteraard tevreden. Hij merkt dan ook op dat er tussen hem en de 'bekeerde' ethologen geen verschil van mening meer bestaat. ${ }^{36}$

Conclusie. Tot nu toe is de controverse tussen ethologen en psychologen op het niveau van de theoretische veronderstellingen geanallyseerd, waarbij de waarde van Kuo's onderzoek voor het aanleg-omgeving vraagstuk de inzet van de discussies vormde. Daaruit kwam naar voren dat er overeenstemming is bereikt tussen sommige ethologen en psychologen. Deze consensus werd mogelijk doordat een aantal veronderstellingen werden verworpen. Ethologen gaven toe dat op grond van beschrijvend onderzoek niet kon worden beslist of bepaalde gedragspatronen aangeboren zijn. Omgekeerd lieten psychologen de impliciete veronderstelling in Watsons behaviorisme vallen dat rijping geen rol speelt in de ontwikkeling van gedrag. Deze impliciete veronderstelling troffen we nog wel aan bij Kuo, maar niet meer bij Lehrman en Schneirla.

Kuo's onderzoek was in de jaren zestig de aanleiding voor een tweede controverse. In deze tweede controverse stonden neuro-embryologen en psychologen tegenover elkaar. Opnieuw ontstonden er communicatieproblemen. Ditmaal niet op het niveau van de theoretische veronderstellingen, maar op het niveau van de onderzoeksresultaten.

\section{7}

\section{Gedragsembryologie}

Kuo's gedragsembryologisch onderzoek was binnen de embryologie een primeur. Hij liet zien dat psychologen ook prenataal de invloed van omgevingsfactoren op gedrag kunnen onderzoeken. Niettemin kreeg zijn onderzoek tot de jaren zestig geen navolging binnen de psychologie. Daarvoor zijn vier redenen te geven. Ten eerste heeft Kuo zelf nooit 'school' gemaakt. Na zijn opleiding tot psycholoog bij Tolman in Berkeley, Verenigde Staten, was Kuo in 1923 teruggekeerd naar China. Daar merkte hij dat hij een 'Robinson Crusoe in a scientifically uninha" bited island' was. ${ }^{37}$ In 1940 moest hij wegens politieke omstandigheden zijn onderzoek onderbreken en China tijdelijk ontvluchten. Jarenlang hoorde de wetenschappelijke wereld niets meer van de nu zwervende 
Kuo, totdat hij in 1960 weer een artikel publiceerde. Hij bleek zich in Hong Kong gevestigd te hebben. Toen pas kreeg hij een leerling die zijn ideeễn op interessante wijze heeft uitgewerkt. Een tweede reden waarom Kuo geen school maakte schuilt in het feit dat de overheersende theorie in de psychologie tot de jaren vijftig het behaviorisme was, waarbinnen een onderzoeksgebied als de gedragsembryologie niet paste. De belangstelling van de onderzoekers ging uit naar leerprocessen hetgeen een totaal ander probleemveld is dan de ontwikkeling van embryonaal gedrag. Ten derde zou ik willen wijzen op het feit dat gedragsembryologisch onderzoek technisch bijzonder moeilijk is. Pas in de jaren zestig was men in staat om het onderzoek te perfectioneren, wat vermoedelijk daarvoor niet mogelijk was. Ten slotte is de embryologie voor biologen tot ver in de jaren zestig een neuro-anatomische en neurofysiologische aangelegenheid geweest. Sinds het monumentale werk van Preyer, Specielle Physiologie des Embryo, uit 1885, hielden biologen zich bezig met fysiologische problemen, zoals het ontstaan van reflexen, of de ontwikkeling van het zenuwstelsel, maar niet met de invloed van omgevingsfactoren op embryonaal gedrag.

In de biologische theorievorming stond de Coghill-Windle controverse centraal. ${ }^{38}$ Coghill was van mening dat de ontwikkeling van embryonaal gedrag begon bij ongedifferentieerde patronen waarbinnen reflexen ontstaan, terwijl Windle dacht dat de eerste bewegingen van embryo's reflexen waren die later tot patronen werden geïntegreerd. Juist omdat deze controverse onoplosbaar leek, stokte de theorie ontwikkeling en werd er in de periode 1940-1960 weinig onderzoek verricht. Het onderzoek kwam pas weer op gang toen Hamburger in 1963 de controverse op bijna triviale wijze oploste. ${ }^{39}$ Volgens Hamburger moeten de twee verklaringen niet als twee elkaar uitsluitende verklaringstypen worden opgevat, maar kunnen beide verklaringstypen worden gebruikt om de ontwikkeling van embryonaal gedrag te onderzoeken. De controverse kwam volgens hem voort uit een te snelle generalisatie van de ene diersoort naar de andere. De theorie van Coghill, gebaseerd op onderzoek naar de salamander, kan niet zo maar toegepast worden op hogere dieren terwijl de theorie van Windle, gebaseerd op onderzoek naar zoogdieren, niet opgaat bij lagere dieren.

In de gedragsembryologie zijn er dus twee onderzoekstradities aan te wijzen. Door biologen is er onderzoek gedaan naar de ontwikkeling van het zenuw-spiersysteem terwijl Kuo onderzoek heeft verricht naar de invloed van omgevingsfactoren om embryonaal gedrag. Deze twee benaderingswijzen van embryonaal gedrag hoeven elkaar niet uit te sluiten, maar opnieuw zal blijken dat ze niet volledig complementair 
waren. Het aanleg-omgeving vraagstuk was ook hier de aanleiding tot een geschil tussen biologen en psychologen.

\section{8}

\section{De tweede controverse}

$\mathrm{Na} 25$ jaar neuro-anatomisch en neurofysiologisch onderzoek kreeg Hamburger in 1959 belangstelling voor de beweeglijkheid van embryo's. Hij begon toen met een uitgebreid onderzoek naar de spontaniteit van embryonaal gedrag. Deze belangstelling van Hamburger kwam niet zo maar uit de lucht vallen. Lorenz was op basis van onderzoek van von Holst tot de conclusie gekomen dat aangeboren gedragspatronen door spontane, automatische processen in het zenuwstelsel veroorzaakt worden. ${ }^{40}$ Voor neuro-embryologen werd het dus interessant om nat te gaan of spontane processen ook een rol spelen in de ontwikkeling van gedrag. ${ }^{41}$ Zo kon er een link gelegd worden tussen het embryologisch en ethologisch onderzoek. ${ }^{42}$ In de tweede plaats kon Hamburger de Coghill-Windle controverse voorlopig naar het tweede plan schuiven door de nadruk te leggen op de spontaniteit van gedrag. Wanneer immers de allereerste bewegingen spontaan zijn, dus niet reactief, dan hoeft men geen rekening te houden met de reflectorische activiteit van het embryo.

Hamburger c.s. onderzochten de spontaniteit van embryonale bewegingen werd bij kippeëmbryo's. ${ }^{43}$ Uit dit onderzoek naar de algemene beweeglijkheid van kippëembryo's bleek dat er ritmische patronen in de embryonale bewegingen voorkomen, die corresponderen met de activiteit van de neuronen in het zenuwstelsel. Deze patronen werden volgens Hamburger c.s. door spontane, vooralsnog onbekende, processen in het zenuwstelsel opgewekt. Bovendien bleek uit hun onderzoek, dat embryo's al actief bewegen op een stadium dat de reflexbogen tussen zintuigen en spieren nog niet volledig zijn uitgegroeid. Informatie, doorgegeven via de zintuigen, kan dus in deze fase van de ontwikkeling geen invloed uitoefenen op de optredende actieve bewegingen. Nadat de reflexbogen gesloten waren probeerden Hamburger c.s. de actieve bewegingen met onder andere een babyhaar te stimuleren. Dit had geen effect. Hamburger kwam dan ook tot de conclusie dat de beweeglijkheid van het embryo spontaan is, dat wil zeggen dat de bewegingen tot stand worden gebracht door processen binnen het zenuwstelsel, onafhankelijk van zintuigprikkels daarbuiten.

Deze conclusie van Hamburger werd door de psycholoog Gottlieb, die in de jaren zestig uitgebreid onderzoek heeft gedaan naar de invloed van ervaring op embryonaal gedrag, aangevochten. Toen Gottlieb be- 
langstelling kreeg voor het gedrag van embryo"s, nodigde hij Kuo uit om een tijd op zijn laboratorium te komen werken zodat hij zich de technieken en ideeën van Kuo eigen kon maken. Dit resulteerde in een gezamenlijk artikel ${ }^{44}$, waarin zij een beschrijving gaven van de gedragsontwikkeling van de pekingeend en een vergelijking maakten met het onderzoek van Kuo naar de kip uit de jaren dertig. De gedragsontwikkeling van de pekingeend en de kip bleken grotendeels overeen te komen. Omdat Gottlieb net als Kuo geïnteresseerd was in de invloed van ongevingsfactoren op de ontwikkeling, vinden we in dat artikel de door Kuo geopperde mogelijkheden. Zo sloten zij bijvoorbeeld niet uit dat de actieve kopbewegingen ontstaan als gevolg van de voorafgaande tactiele stimulatie door de hartslag, hetgeen uiteraard in strijd was met de ideeën van Hamburger. Niettemin vonden Gottlieb en Kuo dat beschrijvingen alleen niet voldoende zijn. Alleen experimenteel onderzoek zou uitsluitsel kunnen geven. Deze conclusie verbonden zij met een belangrijke theoretische beslissing: het begrip 'ervaring' is te ruim voor experimenteel onderzoek. In plaats daarvan kozen zij het begrip 'zelfprikkeling', in navolging van suggesties van onder andere Lehrman en Schneirla. ${ }^{45}$ Door zelfprikkeling te onderzoeken dachten zij de bijdrage van het organisme aan zijn eigen ontwikkeling te kunnen onderzoeken.

Deze gegevens vormden de achtergrond van het debat dat na 1965 tussen Gottlieb en Hamburger ontstond. In eerste instantie stonden daarin de theoretische veronderstellingen ter discussie. Als neuro-embryoloog was Hamburger niet geinteresseerd in de speculaties van, wat hij noemde, behavioristen en ontwikkelingspsychologen. Als psycholoog interesseerde Gottlieb zich niet voor het neuro-embryologisch onderzoek: zijn belangstelling ging louter uit naar de rol van ervaring en zelfprikkeling in de ontwikkeling van gedrag. Het gedrag van embryo's werd dus op twee verschillende wijzen benaderd. Voor Hamburger waren de embryonale bewegingen neurofysiologische fenomenen, terwijl volgens Gottlieb het embryo al in een vroeg stadium van de ontwikkeling reactief was. Het debat tussen Gottlieb en Hamburger bleef echter miet op het niveau van de theoretische veronderstellingen steken. Al snel veranderden zij een aantal theoretische veronderstellingen en verplaatste het debat zich naar het niveau van de feiten. Gottlieb bijvoorbeeld geloofde tot 1966 niet dat bewegingen van embryo's spontaan konden zijn. Toen veranderde hij echter van mening omdat Hamburger c.s. lieten zien dat embryo's spontaan bleven bewegen nadat een deel van de afferente banen verwijderd was en sensorische prikkeling dus geen rol kon spelen. Omgekeerd liet Hamburger al snel zijn idee varen dat de beweeglijkheid van embryo's volledig spontaan is, dat wil zeggen onafhankelijk van zintuiglijke prikkels. Hamburger c.s. preci- 
seerden hun ideeën op dit punt. In hun onderzoek was nog niet uitgesloten, dat de amplitude of frequentie van bewegingen beinvloed zou kunnen worden door zintuigprikkels. Gottlieb voegde daar later nog een mogelijkheid aan toe: in het onderzoek van Hamburger ging het om directe verbanden, zodat niet uitgesloten is dat prikkeling in een vroeg stadium invloed uitoefent op de ontwikkeling van motorische patronen in een veel later stadium. Deze voorbeelden laten zien dat, door weder zijdse kritiek, Hamburger en Gottlieb de -zoals dat achteraf heet- naïeve veronderstellingen hebben laten vallen. Maar van volledige overeenstemming was nog geen sprake. Hamburger c.s. betwijfelden bijvoorbeeld nog steeds dat zelfprikkeling een rol speelt in de ontwikkeling van embryonaal gedrag. $\mathrm{Zij}$ hadden hiervoor ook goede redenen. Oppenheim, een leerling van Hamburger, liet zien dat het onderzoek van Kuo uit de jaren dertig op dit punt discutabel was.

Oppenheim herhaalde op aanraden van Hamburger een experiment van Kuo uit 1932. ${ }^{46}$ Kuo had gevonden dat het amnion, dat het embryo omhult en gladde spieren bevat, in bepaalde stadia van de ontwikkeling contraheert waardoor het embryo schommelende bewegingen maakt. Door het amnion te verwijderen, had Kuo ontdekt dat er een afname optrad in de bewegingen van het embryo. Hieruit concludeerde hij dat amnioncontracties dienst doen als stimuli voor actieve bewegingen. Oppenheim herhaalde dit experiment in 1966, maar hij vond geen verschillen in embryonale activiteit tussen embryo's met en zonder amnion. Hoewel Oppenheim zelf voorzichtig was bij de beoordeling van de verschillen tussen Kuo's experiment en het zijne, meenden Hamburger c.s. toch de conclusie te mogen trekken dat Kuo's hypothese hiermee weerlegd was. ${ }^{47}$ In 1967 verscheen het theoretisch boek van Kuo over de ontwikkeling van gedrag, waarin Kuo het experiment van Oppenheim kritiseerde. ${ }^{48}$ Oppenheim had volgens Kuo allerlei factoren over het hoofd gezien en had daardoor geen verschillen gevonden. Bovendien, merkte Kuo snedig op, hadden Hamburger c.s. toch geen belangstelling voor het werk van psychologen, omdat zij uitsluitend keken naar de spontaniteit van embryonaal gedrag. Deze kritiek werd door Oppenheim serieus genomen. Op verzoek van Gottlieb voerde hij opnicuw experimenten uit waarbij hij rekening hield met de kritiek van Kuo. Na deze experimenten bleek er wel een verschil te zijn tussen embryo's met en zonder amnion, althans in een bepaalde fase van de ontwikkeling. Maar niet in de door Kuo gevonden richting: Oppenheim vond nu dat embryo's zonder amnion in een bepaalde fase juist een toename vertoonden in beweeglijkheid. Dit zou kunnen betekenen dat amnioncontracties de beweeglijkheid van embryo's remmen. Het is interessant om de reactie van Gottlieb op dit resultaat te vermelden. Hij merkte op dat 
het stadium waarop amnioncontracties mogelijk cen remmende invloed hebben verschilde van het stadium waarop Kuo had gevonden dat amnioncontracties een opwekkende invloed hebben. Gottlieb sloot kortom niet uit dat Kuo toch gelijk had, maar vond dat nieuwe experimenten uitsluitsel moesten brengen. In 1970 ontwikkelde Oppenheim een nieuwe methode waarmee hij het probleem wederom te lijf ging. De amnioncontracties bleken sterk af te nemen wanneer de temperatuur in de observatiekamer werd verlaagd. Op deze wijze kon hij, door de temperatuur te variëren, nagaan of er verschillen optraden in de beweeglijkheid. Dit keer vond hij geen verschillen. Oppenheim concludeerde hieruit dat amnioncontracties waarschijnlijk noch opwekkende, noch remmende invloed uitoefenen op de bewegingen van embryo's. ${ }^{49}$ De eerder waargenomen remmende invloed schreef hij nu toe aan bij-effecten van de operatie.

Dit voorbeeld laat zien dat Kuo's observaties en experimenten door uitgebreid experimenteel onderzoek gekritiseerd zijn. Oppenheim heeft grote delen van Kuo's onderzoek herhaald en kwam zelden tot dezelfde resultaten. Tekenend voor de precisie waarmee Oppenheim the werk ging is de volgende anekdote. Om na te gaan hoe Kuo werkte heeft Oppenheim Kuo's vaselinetechniek bestudeerd. Kuo knipte een venstertje in de schaal van een kippeëi en dekte de binnenste membraan (die opaak is) af met vloeibare vaseline. Voor deze laatste handeling gebruikte Kuo een Chinees penseel. In normale situaties zou een onderzoeker, wanneer hij deze methode wil toepassen, genoegen nemen met een penseel uit de eerste de beste verfwinkel. Oppenheim niet. Hij verzocht Kuo hem eenzelfde penseel toe te sturen en kreeg die per omgaande post.

Niet alleen historisch, maar ook wetenschapstheoretisch is Oppenheims kritiek op Kuo's onderzoek buitengewoon interessant. Hij meent namelijk aangetoond te hebben dat Kuo zijn waarnemingen en experimenten met een 'omgevingsbril' op heeft verricht. Hierbij gaat het dan om de veronderstelling van Kuo dat de termen 'stimulus' (omgeving) en 'response' (verandering in gedrag) de enige termen zijn die men bij het onderzoek nodig heeft. Deze veronderstelling, waarvan Kuo inderdaad in de jaren dertig uitging, heeft een aantal consequenties voor de wijze waarop hij naar embryo's keek. Ten eerste kreeg Kuo's theorie hierdoor een sterk periferalistisch karakter: er is geen plaats voor rijpingsprocessen in zijn theorie. Ten tweede leidde Kuo's theorie tot de gedachte dat elke prikkel uit de omgeving een verandering in het gedrag teweegbrengt. Door deze typisch behavioristische gedachte ziet Kuo twee zaken over het hoofd. Hij negeert de mogelijkheid, dat bewegingen 
passief kunnen zijn, ến de mogelijkheid, dat prikkels uit de omgeving niet alleen bewegingen kunnen opwekken, maar ook kunnen renmen.

Oppenheim concludeert dat een groot deel van Kuo's waarnemingen en experimenten subjectief waren. ${ }^{30}$ Vanuit zijn gezichtspunt een terechte conclusie. Deze conclusie is voor de wetenschapsfilosoof echter niet erg bevredigend. De wetenschapsfilosoof wil een verklaring horen. Die is in het onderhavige geval niet moeilijk te geven. Kuo was opgeleid tot behaviorist: het stimulus-response mechanisme was zijn gids, het maatgevend voorbeeld voor op te lossen problemen. Impliciet had hij geleerd dat rijpingsprocessen geen rol spelen in de ontwikkeling van gedrag, en dat elke stimulus uit de omgeving een verandering in het gedrag teweegbrengt. Hoewel Kuo in de jaren twintig belangrijke veranderingen in het behaviorisme van Watson had aangebracht, waren deze impliciete veronderstellingen ongewijzigd gebleven. Precies op dit punt bekritiseerde Oppenheim Kuo's waarnemingen en experimenten. Hij liet zien dat Kuo's onderzoek vanwege deze veronderstellingen 'subjectief' was.

De resultaten van Oppenheims onderzoek werden uiteraard direct geaccepteerd door Hamburger. Gottlieb betoonde pas zijn instemming, nadat hij had laten zien dat er op basis van Kuo's ideeën interessant onderzoek gedaan kon worden.

\section{9}

\section{Het discriminatievermogen van pekingeenden}

Centraal in het onderzoek van Gottlieb staat de vraag waardoor leden van een soort soortgenoten leren herkennen. In de eerste fase van het onderzoek richtte Gottlieb zich op de volgresponse van kuikens en vroeg zich af waardoor kuikens van kippen en eenden na verloop van tijd hun moeder gaan volgen. Hij nam in eerste instantie aan dat dit het gevolg is van inprenting: kuikens 'leren' in relatief korte tijd de lokroep van de moeder herkennen. ${ }^{51}$ Dit idee ontleende Gottlieb aan het onderzoek van Lorenz uit de jaren dertig. Volgens Lorenz brengen de allervroegste ervaringen met bewegende voorwerpen onmiddellijk na het uitkomen een blijvende band met die voorwerpen teweeg. De opgedane indrukken zouden onomkeerbaar worden ingeprent en niet alleen veroorzaken dat een dergelijk voorwerp gevolgd wordt alsof het de moeder is, maar ook dat soortgelijke voorwerpen later als partner worden gekozen. Gottlieb was vooral geïnteresseerd in de rol van de lokroep in het inprentingsproces. Tijdens het veldonderzoek nam hij waar dat moeders de lokroep al bij het ei vertonen. Daarom veronderstelde hij 
in de periode 1961-1962 dat inprenting prenataal een rol kon spelen. Dat wil zeggen: hij rekte het inprentingsbegrip van Lorenz op. In 1963 verliet hij dit idee volledig: geheel naïeve kuikens (kuikens die nooit de lokroep van de moeder gehoord hebben) bleken een voorkeur te vertonen voor de lokroep van de eigen soort. Hij besloot toen Kuo in te schakelen en ging over op gedragsembryologisch onderzoek. In 1965 toonde Gottlieb aan dat embryo"s in het ei selectief reageren op de lokroep van de eigen soort. Hij toonde dit aan door het meten van onder andere de snavelbewegingen van embryo's. Embryo's die de lokroep van de eigen soort hoorden vertoonden een afname van de snavelbewegingen terwijl de lokroep van een andere soort geen effect had. Na 1965 probeerde Gottlieb na te gaan welke prikkels de ontwikkeling van het selectieve discriminatievermogen kunnen beinvloeden. Hij ging over op een gecombineerd prenataal en postnataal onderzoek, dat wil zeggen dat hij prenataal de condities waaronder een embryo zich ontwikkelt, varieerde en vervolgens keek of er postnataal veranderingen in het gedrag optraden. De strategie die Gottlieb hierbij volgde was gebaseerd op ideeën van Lehrman en Schneirla. Hij isoleerde embryo's voor prikkels en gaf daarbij aan welke prikkels dat waren. Van de experimenten die Gottlieb na 1965 heeft uitgevoerd zal ik er twee bespreken. ${ }^{52}$

In 1968 publiceerde Gottlieb de resultaten van zijn eerste isolatie-experiment. Hij vergeleek in dat experiment twee groepen embryo's: embryo's die geheel geïsoleerd en embryo's die gezamenlijk zijn opgegroeid (de natuurlijke situatie). Het verschil tussen de twee groepen is het volgende. Gottlieb en Kuo hadden in 1965 beschreven dat embryo's circa 3 dagen voor het uitkomen geluiden produceren. Gezamenlijk opgegroeide embryo's horen dus de geluiden van de buren, en de geïsoleerd opgegroeide embryo's blijven daarvan verstoken. Uit dit experiment bleek dat geïsoleerd opgegroeide embryo's een minder adequaat discriminatievermogen ontwikkelen dan gezamenlijk opgegroeide embryo's. Het tweede experiment is interessanter. Geïsoleerd opgegroeide embryo's blijwen niet van alle geluiden verstoken: ze horen hun eigen stem. Het voorafgaande onderzoek wettigt de veronderstelling dat het horen van de eigen stem invloed uitoefent op de ontwikkeling van het selectieve discriminatievermogen. De invloed van zelfprikkeling kan worden onderzocht. Het bleek mogelijk dit experimenteel te onderzoeken doordat Gottlieb de invloed van de eigen stem wist uit te schakelen door embryo's vier dagen voor het uitkomen te opereren. Hij verstijfde de membranen van de syrinx met collodion waardoor de embryo's tijdelijk stemloos werden. Als controlegroep gebruikte Gottlieb embryo's die een schijnoperatie hadden onder gaan. Nu bleek uit dit experiment, dat het discriminatievermogen bij de stemloos gemaakte 
embryo's verloren was gegaan en niet bij de enbryo's die een schijnoperatie hadden ondergaan. Men zou dus kunnen concluderen dat het discriminatievermogen door zelfprikkeling ontstaat. Dit is echter onjuist. Gottlieb had namelijk al aangetoond dat embryo's 5 dagen voor het uitkomen selectief reageren op de lokroep van de eigen soort, door verschillen in snavelbewegingen te registreren, terwijl embryo's pas 3 dagen voor het uitkomen hun eigen stem horen. Gottliebs experimenten tonen dus wel aan dat zelfprikkeling invloed heeft op de ontwikkeling van het discriminatievermogen, maar ook dat het niet ontstaat door zelfprikkeling. Het is immers al in een bepaalde vorm aanwezig is voordat embryo's geluiden produceren. Voortgezet onderzoek zou kunnen aantonen dat het discriminatievermogen, dat 5 dagen voor het witkomen aanwezig is, door rijping is ontstaan.

Het gedragsembryologisch onderzoek van Gottlieb was het eerste onderzoek in de embryologie dat de ideeën van Lehrman, Schneirla, en anderen bevestigde. De experimenten laten zien dat de dichotomie tussen rijping en ervaring (of zelfprikkeling) ongeschikt is om de ontwikkeling van gedrag te bestuderen. Men kan niet zeggen dat het discriminatievermogen instinctief is, en dus dat het soortspecifiek is en daarom door rijping ontstaat (zoals Lorenz dacht) ${ }^{53}$ Evenmin kan men volhouden dat het discriminatievermogen door leerprocessen ontstaat (Watsons ideeën). Gottlieb geeft het zelf schematisch weer. Oorspronkelijk ging men uit van het schema:

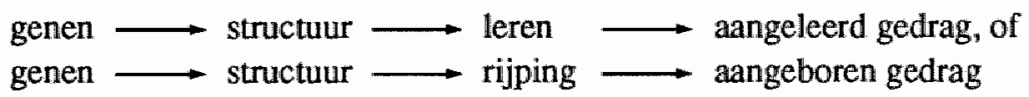

In dit schema herkennen we het behaviorisme van Watson en de ethologie van Lorenz. Watson was immers van mening dat gedrag door leerprocessen ontstaat, terwijl Lorenz dacht dat gedrag uit aangeboren en aangeleerde elementen is opgebouwd. Impliciet veronderstelde Lorenz dat de aangeboren elementen door rijping ontstaan. Gottlieb nu, gaat uit van het volgende schema:

genen $\longrightarrow$ structurele rijping $\longrightarrow$ functie $\longleftrightarrow$ gedrag

In dit schema is de dichotomie tussen rijping en leren verdwenen. Wanneer we ons beperken tot het onderzoek van Gottlieb wil dit schema het volgende zeggen: door structurele rijping kunnen embryo's geluiden produceren die op hun beurt de ontwikkeling van het discriminatievermogen beïnvloeden. De geluiden vervullen een functie in de ontwikkeling van gedrag en kunnen veranderingen teweeg brengen in de biolo- 
gische eigenschappen. Die veranderingen kunnen weer constitutief zijn in de werdere ontwikkeling. De ontwikkeling is daarom een tweebaansweg. in beide richtingen is er verkeer. De relatie tussen structuur en functie noemt Gottlieb niet voor niets 'bidirectional'.

De resultaten van Gottliebs onderzoek werden door Hamburger c.s. zonder kritiek geaccepteerd. Zij gaven toe dat zelfprikkeling een rol kan spelen in de ontwikkeling van gedrag. $\mathrm{Er}$ is dus overeenstemming bereikt op het niveau van de onderzoeksresultaten. Gottlieb accepteerde Oppenheims kritiek op het onderzoek van Kuo en, omgekeerd, Hamburger en Oppenheim accepteerden de door Gottlieb geproduceerde onderzoeksresultaten. Niettemin plaatste Hamburger nog een paar kanittekeningen bij het onderzoek van Gottlieb, die de moeite van het bespreken waard zijn. ${ }^{54}$ De eerste kanttekening betreft het tijdstip waarop ervaring een rol gaat spelen. Dat is in Gottliebs onderzoek 3-4 dagen voor het uitkomen. In die fase van de ontwikkeling is er volgens Hamburger geen verschil tussen een pas uitgekomen kuiken en een 'embryo'. Hamburger stelt daarom voor om in die laatste fase niet meer over embryo's te spreken en de term 'embryo' te reserveren voor de vroegere stadia. In Lakatosiaanse termen wil dit zeggen dat Hamburger het begrip 'embryo' inperkt. ${ }^{55}$ De tweede kanttekening heeft betrekking op Gottliebs theorie, de tweebaansweg tussen structuur en functie. Ook daarvoor geldt volgens Hamburger dat die opgaat woor de latere fases van de embryonale ontwikkeling. Uit zijn onderzoek blijkt namelijk dat de allereerste bewegingen spontaan zijn en bovendien blijft het reflectorisch systeem volgens Hamburger gedurende een groot deel van de embryonale ontwikkeling latent. Zijn these is dus dat Gottliebs theorie slechts opgaat in de latere fases van de ontwikkeling.

\subsection{0}

\section{Aanleg, omgeving en interactionisme}

De beschrijving van de episode liet zien dat er op twee niveaus consensus is bereikt door biologen en psychologen. Eerst bereikten sommige ethologen en psychologen overeenstemming op het niveau van theoretische veronderstellingen; later bereikten psychologen en neuroembryologen overeenstemming op het niveau van de onderzoeksresultaten. De traditionele dichotomieèn tussen aangeboren en aangeleerd, rijping en ervaring, bleken ongeschikt om de ontwikkeling van gedrag te verklaren. Watsons idee dat instincten in feite geleerde gewoonten zijn en Lorenz' idee, dat gedragspatronen of instinctief of aangeleerd zijn, heeft men laten vallen. De ontwikkeling van gedrag wordt nu in 
termen van de logica van subcontraire begrippen (rijping en/of ervaring) geformuleerd, terwijl Watson en Lorenz de logica van contraire begrippen (instinctief of aangeleerd) gebruikten.

Dat onderzoekers verschillende logica's gebruikten, was op te maken uit de twee controversen. Zo zagen we bijvoorbeeld dat in de eerste controverse Lehrman uitging van de logica van subcontraire begrippen, terwijl Lorenz uitging van de logica van contraire begrippen. Deze logische verschillen hingen nauw samen met hun verschillende benaderingen van ontogenetische problemen. Lorenz bestudeerde de ontogenie vanuit een evolutionair perspectief en legde de nadruk op het belang van de 'uiteindelijke oorzaken' voor gedrag. Impliciet veronderstelde Lorenz daardoor dat evolutionair aangepast gedrag door rijping tot stand kwam. Lehrman daarentegen benadrukte de rol van aanleg- en omgevingsfactoren bij de 'onmiddellijke oorzaken' van gedrag. In de tweede controverse bleek dat Kuo's onderzoek - in de woorden van Oppenheim - 'subjectiel' was vanwege zijn behavioristische achtergrond. Omdat Kuo in de jaren twintig en dertig bleef denken in termen van 'stimulus' en 'response', handhaafde hij een impliciete veronderstelling in Watsons behaviorisme, namelijk de gedachte dat de orde in het gedrag voornamelijk door omgevingsinvloeden tot stand wordt gebracht.

Op grond van de historische analyse kunnen we concluderen dat er een nieuw perspectief is ontstaan dat door zowel aanleg- als omgevingsdenkers wordt verdedigd. Dat nieuwe perspectief verschilt zowel van het behaviorisme van Watson als de ethologie van Lorenz. Is er nu ook een nieuwe disciplinaire matrix ontstaan? Was hier sprake van een revolutie in de Kuhniaanse betekenis? Er zijn tenminste drie argumenten om deze vragen ontkennend te beantwoorden.

In de eerste plaats hebben onderzoekers gedurende de gehele periode gestadig puzzels opgelost en is er geen revolutionaire fase aan te wijzen waarin Popperiaans problemen werden opgelost. Kuhns trits: normale wetenschap - revolutionaire wetenschap - normale wetenschap, vinden we hier niet terug. De transformatie die het aanleg-omgeving vraagstuk heeft ondergaan was niet het resultaat van deductief onderzoek.

In de tweede plaats zijn de methoden van onderzoek en de normen en waarden niet noemenswaardig veranderd. In het nieuwe perspectief zijn ze 'geïntegreerd', dat wil zeggen dat ethologen meer gebruik zijn gaan maken van (behavioristische) experimentele technieken, terwijl psychologen meer oog hebben gekregen voor het belang van observaties in natuurlijke situaties. Een nieuwe 'exemplar' gekoppeld aan nieuwe experimentele technieken is met andere woorden niet te ontdekken. In 
de lokale, experimentele situatie zijn geen nieuwe technieken ontwikkeld. Die werden 'geleend' van al bestaande tradities in de biologie en de psychologie.

Dat blijkt in de derde plaats ook uit het feit dat de twee oudere perspectieven nog steeds als heuristiek functioneren voor het genereren van nieuwe theoretische variaties. In de lokale onderzoekssituatie hebben de twee oudere theoretische perspectieven afgedaan, maar globaal is de tegenstelling blijven bestaan omdat beide nog steeds als fonds functioneren voor de ontwikkeling van ideeën. De onderzoeksresultaten van Gottlieb bijvoorbeeld kunnen zowel binnen een evolutionair als een leertheoretisch perspectief worden ingepast. Aanlegdenkers zullen zich afvragen waarom deze ontwikkelingsstrategie is uitgeselecteerd in de evolutie; omgevingsdenkers zullen opmerken dat dit ontwikkelingspatroon laat zien dat de ontogenie 'flexibel' verloopt en de link met latere leerprocessen benadrukken.

Dat de trits: puzzeloplossen - probleemoplossen - puzzeloplossen hier niet voorkomt heeft belangrijke consequenties voor het verloop van discussies. Omdat de 'nieuwe' theorie in de lokale onderzoekssituatie is gegenereerd en niet het resultaat was van 'revolutionaire wetenschap', rijst bij onderzoekers de vraag of het een nieuw perspectief is hoe dat perspectief zich verhoudt tot de oudere theorieën. Dit heeft in de eerste plaats als consequentie dat kennis in een sociale dimensie transformaties ondergaat. Terwij] in de lokale onderzoekssituatie overeenstemming heerst ten aanzien van concrete onderzoeksresultaten, ontstaan buiten de lokale onderzoekspraktijk conflicten ten aanzien van die onderzoeksresultaten tussen aanlegdenkers en omgevingsdenkers. Twee voorbeelden kunnen dit illustreren. In 1953 accepteerde Lehrman het onderzoek van Kuo zonder kritische kanttekeningen te plaatsen. Zeventien jaar later schrijft hij, nadat hij onder andere het werk van Hamburger heeft bestudeerd, dat hij het werk van Kuo nu niet meer zou gebruiken om de ideeën van Lorenz te kritiseren. ${ }^{56}$ Zoals te verwachten vermeldt hij vervolgens dat hiervoor nu het werk van Gottlieb zou nemen. Deze ideeën van Lehrman staan in schril contrast met die van bijwoorbeeld McVicker Hunt. McVicker Hunt gebruikte in 1968 Kuo's 'wonderful behavioral observations' om nativistische opvattingen te bestrijden, dat wil zeggen dat hij het aanleg-omgeving vraagstuk weer in termen van de oude tegenstellingen formuleert. ${ }^{57}$ Van belang is de vaststelling dat McVicker Hunt niet in kringen van embryologen verkeerde. Een tweede voorbeeld: Eibl-Eibesfeldt, een leerling van Lorenz, gebruikte in 1967 het onderzoek van Hamburger c.s. om de kritiek van Lehrman en anderen te pareren. Volgens hem liet het onderzoek van Hamburger cis. zien dat de ideeën van Lorenz juist zijn en ook hij 
formuleert het aanleg-omgeving vraagstuk weer in termen van de oude tegenstellingen. ${ }^{58}$ Van belang is ook hier dat Eibl-Eibesfeldt niet in kringen van embryologen verkeert. Deze twee voorbeelden laten zien dat onderzoekers, die tot verschillende kringen behoren, verschillende interpretaties kunnen geven van hetzelfde onderzoek. Terwijl McVicker Hunt in 1968 schrijft dat nativistische theorieèn door Kuo's onderzoek 'weerlegd' zijn, kan Eibl-Eibesfeldt vrolijk opmerken dat Kuo's theorie is weerlegd. Beide opvattingen zijn echter op dat moment in feite achterhaald. De voorbeelden laten zien dat het zin heeft om en onderscheid te maken tussen esoterische en exoterische kringen. ${ }^{59} \mathrm{Zij}$ tonen immers aan dat kennis transformaties ondergaat wanneer zij verschuift in een sociale dimensie, van esoterische naar exoterische kringen. Kennis ondergaat met andere woorden niet alleen transformaties in de tijd, maar ook in een sociale dimensie.

In de tweede plaats blijft problematisch of hier sprake is van een nieuwe theorie en hoe die theorie zich verhoudt tot de traditionele perspectieven. Over de experimenteel verkregen onderzoeksresultaten kan men relatief eenvoudig tot overeenstemming komen, maar theoretisch blijft de 'nieuwe' theorie problematisch. Gottlieb noemt het nieuwe perspectief 'probabilistische epigenese'; Hamburger vindt deze benaming onzinnig omdat volgens hem de ontogenetische ontwikkeling "deterministisch' verloopt. In deze theoretische discussie keert de tegenstelling tussen aanleg en omgeving weer terug: 'probabilistisch' is namelijk verbonden met 'flexibel' en dus veranderbaar terwijl 'deterministisch' verbonden is met 'rigide' en dus moeilijk veranderbaar. Theoretisch bestaat er dus nog steeds onduidelijkheid omdat die theorie ingebed is gebleven in de traditionele disciplinaire matrices. Ook de onderzoekers onderkennen dat hier een probleem ligt. Tijdens interdisciplinaire projecten merkt men dat de oude tegenstellingen nog steeds aanwezig zijn:

'No matter how vigorously we agreed on the futility of a nature-nurture dichotomization, we still managed to speak past one another at times when discussing the essence of the developmental interaction of the genome and its environment. Perhaps the difficulty is fundamentally a matter of the way our minds function. We seem to think in discrete categories. Although interactive dynamics of genome and environment are now generally accepted, almost of necessity individuals divide the problem into genetic and environmental components. This is forgivable for experimental analysis, but it is disturbing as a mental habit. ${ }^{60}$ 
In de lokale onderzockssituatie, waar concrete puzzels worden opgelost, onderkent men dat de traditionele dichotomie onbruikbaar is. De onbruikbaarheid van de oudere tegenstelling kan men als het ware in een experimentele situatie zien. Zodra onderzoekers echter gaan discussiëren, vervalt men gemakkelijk in de oudere tegenstelling. Omdat de nieuwe theorie het resultaat is van puzzeloplossen en niet van deductief problemen oplossen, maakt men op theoretisch vlak nog steeds gebruik van de twee oudere theorieën. ${ }^{61}$ De traditionele theorieën die werden gebruikt voor de interpretatie van de ontwikkeling van gedrag zijn niet onjuist, maar wel (delen van) de interpretaties die met behulp van deze theorieen werden gegenereerd. In figuur 3 staat dit weergegeven:

Figuur 3

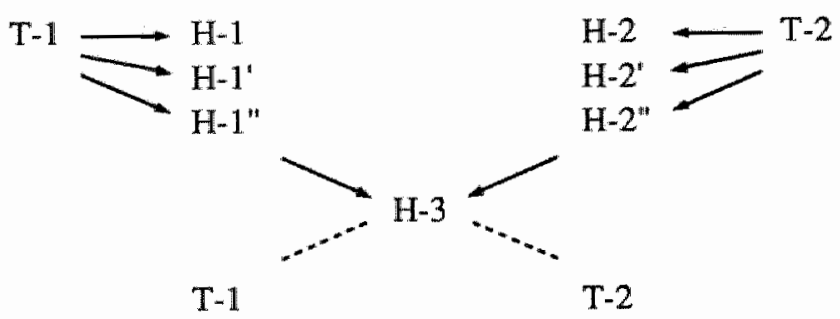

Dit ontwikkelingspatroon vinden ook terug in andere delen van de levenswetenschappen. Binnen de embryologie bijvoorbeeld is de tegenstelling tussen mechanicisme (gekoppeld aan reductionisme) en vitalisme (gekoppeld aan holisme) volgens sommigen in de loop van deze eeuw vervangen door het 'organicisme'. Op experimenteel niveau kan men laten zien dat oudere tegenstelling inadequaat is. Theoretisch is echter allerminst duidelijk of het organicisme een nieuwe theorie is. Sommigen beweren dat het organicisme eigenlijk vitalisme in een ander jasje is; anderen zien duidelijke affiniteiten tussen organicisme en mechanicisme. Net als in het geval van de gedragsembryologie is met andere woorden de globale tegenstelling blijven bestaan, hoewel die tegenstelling op het niveau van de onderzoeksresultaten niet houdbaar is gebleken. Typisch is ook dat de 'synthese' wordt verdedigd met een beroep op 'experimenteel realisme'. In de experimentele onderzoekssituatie laten de feiten zien dat de oudere dichotomieën onjuist zijn. Theoretisch blijft de gulden middenweg echter een omstreden positie: 'organicists, a minority group in terms of overt allegiance to the framework, continue to engage in polemics, often in vague terms that are hard to relate to actual experimental issues'. ${ }^{62}$ Wie in concreet, empirisch 
onderzoek laat zien dat oudere dichotomieên onhoudbaar zijn, heeft nog geen alternatieve theorie ontwikkeld ter vervanging van de oudere fondsen. De conclusie die Haraway trok naar aanleiding van haar studie naar ontwikkelingen in de embryologie is illustratief en is ook hier van toepassing:

'Organicists reject the reductionistic approach primarily because they refuse to see the world in single terms. They share a root faith that the task of the scientist is not merely to order and test our own generalizations. Experimentally grounded organicism has aimed at constructing a reformed realism that would contribute to the great poet scientist's goal "to restore to the intellect its old privilege of taking a direct view of nature". 63

\subsection{1 \\ Slot}

Het aanleg-omgeving vraagstuk heeft in de embryologie van gedrag een aantal transformaties ondergaan. Het interactionisme is een 'nieuw' perspectief en de uitkomst van controversen tussen twee, traditioneel tegenstrijdige, posities. Op grond van concrete onderzoeksresultaten kan worden beargumenteerd dat de tegenstelling tussen de ethologische aanlegtheorie en de behavioristische omgevingstheorie niet langer houdbaar is.

Deze interpretatie van de ontwikkelingen binnen de embryologie is echter maar de helft van het verhaal. Omdat het interactionisme het resultaat is van puzzeloplossen, blijft het interactionisme omstreden. Bepaalde hypothesen die waren gegenereerd met behulp van achtergrondkennis zijn onjuist, maar die achtergrondkennis zelf stond niet ter discussie. De globale tegenstelling blijft bestaan, omdat de oudere aanleg- en omgevingstheorieën beide nog als fonds fungeren voor het genereren van hypothesen. Dit levert een antwoord op de vraag waardoor onderzoekers, zodra zij gaan discussiëren over het aanleg-omgeving vraagstuk, gemakkelijk vervallen in de tegenstelling tussen aanleg en omgeving. Concrete onderzoeksresultaten laten zien dat de dichotomie tussen aanleg en omgeving onbruikbaar is; theoretische discussies raken als het ware losgekoppeld van de onderzoeksresultaten waardoor aanleg weer tegenover omgeving komt te staan. Het is dan ook niet verwonderlijk dat het interactionisme wordt verdedigd met een beroep op experimenteel realisme, terwijl theoretisch speculeren wordt veracht. 
Hoewel met de notie 'inductieve stijl' de spanning tussen het interactionisme de twee oudere perspectieven kan worden geduid, blijft problematisch waarom het interactionisme wordt verdedigd met een beroep op experimenteel realisme en waarom vaak het belang van zuivere, onbewooroor deelde waarnemingen wordt benadrukt. De feiten laten zien dat aanleg en omgeving in een functionele relatie tot elkaar staan. Deze empiristische retoriek van de onderzoekers zelf suggereert dat consensus is bereikt over waarnemingsuitspraken die kunnen worden onderscheiden van theoretische uitspraken. Theoretisch speculeren werd immers veracht! Dit aspect kan moeilijk met gangbare wetenschapstheoretische noties worden verklaard omdat men er van uitgaat dat alle uitspraken een theoretisch karakter hebben. Popper heeft beargumenteerd dat alle uitspraken theoretisch zijn en dat elke waarneming wordt verricht in het licht van een theorie. Dit element in zijn Zoeklichttheorie van de geest sluit uit dat bij empirisch onderzoek methodologisch niet alle uitspraken functioneren als hypothetische uitspraken. Voor een verklaring van de in de onderzoekspraktijk gangbare empiristische retoriek kan geen beroep worden gedaan op Poppers Zoeklichttheorie.

Wie een alternatief wil ontwikkelen voor Poppers Zoeklichttheorie, bevindt zich echter in onze tijd in slecht gezelschap. De hoofdmoot van het moderne wetenschapstheoretische onderzoek wordt gekenmerkt door een sterk anti-empirisme. Wetenschapssociologische stromingen als het Sterke Programma en het Constructivisme bieden geen aanknopingspunten: zij hanteren alls startpunt voor wetenschapstheoretisch onderzoek het (methodologisch) relativisme. ${ }^{64} \mathrm{De}$ inzet van hun werk is volgens Shapin onder meer het aantonen van de theoriebeladenheid van 'statements of facts' ${ }^{65}$, waardoor men weinig oog heeft voor de mogelijkheid dat bepaalde uitspraken niet theorie-beladen zijn. De enige kandidaat die in aanmerking lijkt te komen is het (metafysisch) realisme van onder anderen Kripke en Putnam. ${ }^{66}$ Deze vorm van realisme dwingt ons om uitgebreid in te gaan op kennistheoretische discussies en dat is, gezien de vraagstelling in deze studie, bezwaarlijk. In deze studie wil ik mij beperken tot de rol van methodologische strategieën in het aanleg-omgeving vraagstuk en kennistheoretische problemen buiten beschouwing laten. Daarom zal ik de kennistheoretische problemen niet bespreken en mij beperken tot de vraag of in de onderzoekspraktijk alle uitspraken functioneren als hypothetische uitspraken, zoals op grond van Poppers Zoeklichttheorie kan worden verwacht, of dat er differentiatie kan worden aangebracht in het methodologisch functioneren van uitspraken. Voor de beantwoording van deze vraag wordt in het volgende hoofdstuk opnieuw 'het probleem van de empirische basis' onder de 
loep genomen. Daarvoor zal ik dit probleem analyseren door nog eens Poppers kritiek op het logisch empirisme te bespreken. Vervolgens zal ik beargumenteren waarom aan de latere filosofie van Wittgenstein een argument kan worden ontleend waarmee het onderscheid tussen de deductieve en inductieve stijl verder kan worden gepreciseerd. 


\section{4 \\ Fenomenen en theorieën De emmertheorie, de zoek- lichttheorie en Wittgenstein}

4.1

Inleiding

De moderne filosofie heeft haar wortels in de wetenschappelijke revolutie. Door de revolutionaire ontwikkelingen binnen de fysica in de zestiende en zeventiende eeuw dienden zich nieuwe filosofische vragen en problemen aan. Kepler, Galileï en later Newton hadden laten zien dat de natuur onderhevig is aan wetten die toegankelijk zijn voor de menselijke rede. De werkelijkheid die door de fysici werd ontdekt had een mechanistisch en wiskundig karakter. Hierdoor ontstond er een kloof tussen de wereld van de verschijnselen en de fysische wereld onafhankelijk van onze waarnemingen. ${ }^{1}$ De wereld zoals die zich aan ons voordoet was vol geluiden, kleuren en geuren, en warm of koud; de fysische wereld daarentegen was een wereld waarin onzichtbare, kleurloze deeltjes geluidloos bewogen. De relatie tussen deze twee werelden stelde filosofen voor nieuwe vragen en problemen. Hoe kunnen wij de fysische wereld ontdekken? Waarin verschilt de fysische wereld van de fenomenale wereld? En als deze twee werelden verschillen, hoe kunnen wij dan kennis verkrijgen over de fysische wereld? Waarmee onderscheiden wij kennis over de fysische wereld van alledaagse kennis en hoe rechtvaardigen wij die kennis?

De antwoorden die filosofen en wetenschappers op dergelijke vragen hebben gegeven oscilleren sinds de wetenschappelijke revolutie tussen extremen die op een continuüm geplaatst kunnen worden. Voorbeelden zijn het empirisme versus het rationalisme, en het realisme versus het fenomenalisme.

Binnen de wetenschapstheorie staat de relatie tussen de fenomenale wereld en de wereld waarover wetenschappelijke theorieën spreken 
bekend als 'het probleem van de empirische basis". Ten aanzien van dit probleem kan men ruwweg twee tegenover elkaar staande visies onderscheiden. Volgens de empiristische visie is zintuiglijke ervaring de empirische basis voor theorieên die via inductie tot ontwikkeling worden gebracht. Kritisch rationalisten verwerpen zowel het inductie-principe als de bijbehorende associatiepsychologie. Volgens hen is er geen empirisch fundament voor kennis en zijn alle waarnemingen geïmpregneerd met theorieën. Alleen de groei van kennis kan worden verklaard: onderzoekers ontwikkelen deductief theorieèn die zij vervolgens proberen te testen aan basiszinnen. Ervaring motiveert volgens Popper de beslissing om een basisuitspraak te aanvaarden of te verwerpen, maar rechtvaardigt nooit een uitspraak. ${ }^{2}$ Volgens Popper kunnen alleen de preferenties van onderzoekers voor theorieën worden gerechtvaardigd.

Ervan uitgaande dat de kennistheoretische kritick van Popper op het inductie-principe terecht is, luidt de vraag in dit hoofdstuk hoe Poppers rationalistische visie op het probleem van de empirische basis kan worden verfijnd. Zijn alle uitspraken theoretisch of kunnen wij een criterium formuleren waarmee theoretische uitspraken kunnen worden onderscheiden van 'waarnemingsuitspraken'? De ontwikkeling van zo'n criterium vormt de opgave van dit hoofdstuk. In paragraaf 4.2 wordt de logisch-empiristische visie op het probleem van de empirische basis uiteengezet, waarbij de nadruk zal liggen op de empiristische uitwerking van het verificatie-principe. Tegen deze achtergrond wordt kort de kritiek van Popper op het logisch empirisme besproken. Ik zal beargumenteren dat Poppers kritiek epistemologisch juist is, maar dat in methodologisch opzicht zijn Zoeklichttheorie gebreken vertoont. Binnen empirisch onderzoek functioneren niet alle uitspraken als hypothetische uitspraken. Voor een nadere analyse hoeven we niet terug te vallen op de logisch-empiristische Emmertheorie. In paragraaf 4.3 wordt betoogd dat het probleem van de empirische basis nog niet is uitgeput. Aan de hand van de latere filosolie van Wittgenstein wordt beargumenteerd dat er, naast een empiristische en een rationalistische, nog een derde positie mogelijk is. Volgens de latere Wittgenstein vormen 'waarnemingsuitspraken' geen fundament voor kennis, zoals de logisch empiristen dachten, maar zijn zij ook geen theoretische uitspraken. In paragraaf $4.4,4.5$ en 4.6 tenslotte worden Wittgensteins ideeën gebruikt om de methodologisch tegenstelling tussen de deductieve en de inductieve stijl verder te verfijnen. 


\section{Popper en de Wiener Kreis}

De wetenschapsfilosofie werd tot in de jaren zestig gedomineerd door de denkbeelden van het logisch empirisme. ${ }^{3} \mathrm{De}$ ideeën die binnen deze stroming zijn ontwikkeld hebben dan ook een blijvende stempel gedrukt op het karakter van wetenschapsfilosofische discussies. Dat geldt niet in de laatste plaats voor het probleem van de empirische basis. De leden van de Wiener Kreis gaven dit probleem een nieuwe wending door het tot een 'talig' probleem te bombarderen dat met logische middelen was te analyseren. De empirische basis van wetenschap was volgens hen de verzameling van empirische uitspraken. Hierdoor lag de nadruk op de betekenis van zinnen. De betekenis van een zin (uitspraak) is zijn methode van verificatie, zo luidt het bekende verificatie-principe. Hoewel de latere kritiek op het logisch empirisme vooral betrekking had op de empiristische uitwerking van het verificatie-principe, bleef de nadruk liggen op een 'talige' analyse van het probleem van de empirische basis. Tegenover het empirisme van de Wiener Kreis stelden Popper, Hanson en vele anderen de theoriebeladenheid van uitspraken. Voor een goed begrip van deze ontwikkelingen is een korte recapitulatie ervan op zijn plaats.

De logisch empiristen maakten een onderscheid tussen een drietal typen zinnen: empirische, analytische en betekenisloze zinnen. Analytische zinnen zijn waar louter op basis van 'talige' conventies en daartoe behoorden de waarheden van de logica. De niet-analytische zinnen werden onderverdeeld met behulp van het verificatie-principe. Door dit principe stringent toe te passen konden betekenisloze zinnen worden onderscheiden van betekenisvolle zinnen.

Het verificatie-principe, dat logisch empiristen aan de Tractatus van Wittgenstein hadden ontleend (hoewel hel daar niet voorkomt) ${ }^{4}$, werd door hen volledig empiristisch uitgewerkt, waarbij men gebruik maakte van ideeën van onder andere Mach en Russell. Via dit principe probeerde men taal te herleiden tot ervaring, wat een verdere specificatie van het principe vereiste. In de jaren twintig en dertig werd hierbij steeds vaker gebruik gemaakt van zogenaamde van ostensieve definities die in de plaats kwamen van andere noties. ${ }^{5}$ In Der Logische Aufbau der Welt van Carnap bijvoorbeeld treffen we nog de notie 'Aufweisung' aan. Wetenschappelijke uitspraken zijn betekenisvol als de voorwerpen waarvan de namen in zinnen woorkomen 'getoond' kunnen worden door 'Aufweisung': 'der hinweisende Gebärde bezeichnet; z.B.: " das dort ist der Feldberg". "6en embryonale vorm van de latere ostensieve definitie was toen wel aanwezig in het werk van Carnap, maar precies was die 
nog niet. Pas nadat Wittgenstein in de gesprekken met Waismann en Schlick uitgebreid had gesproken over ostensieve definities, zien wij deze notie steeds vaker in het werk van de logisch empiristen voorkomen.

De reden van deze belangstelling ligt voor de hand: wie uitgaat van het verificatie-principe en zinnen in de ervaring wil funderen, zal vroeg of laat moeten aangeven hoe zinnen met de werkelijkheid vergeleken kunnen worden. Om de waarheid van een zin vast te kunnen stellen moet men zijn methode van verificatie weten. Maar dat mondt uit in de vraag hoe men de niet verder te definiëren elementen van een zin moet toepassen. Hoe is het mogelijk dat mensen de relevante entiteiten in de wereld herkennen? Ostensieve definities vervulden voor de logisch empiristen de brugfunctie tussen woorden en entiteiten in de wereld. Woorden werden via ostensieve definities gecorreleerd met entiteiten. Deze logische these werd door logisch empiristen aangevuld met de psychologische these dat herkenning het fundament van empirische kennis is. Om bijvoorbeeld een 'naam' toe te kennen aan een kleur moest de kleur worden herkend als die kleur die al eerdler als zodanig was benoemd. Hierin speelde een leerproces een cruciale rol: het toekennen van een 'naam' gebeurde via een herkennings- of associatieproces. De toepassingsregel voor een 'naam' werd dan ook verder psychologisch geduid in termen van 'gelijkheid' met al eerder geleerde voorbeelden waarbij de psychische acten 'herinnering' en 'vergelijking' (Carnaps 'Aehnlichkeitserinnerung') als verklarende termen werden gebruikt. Ondanks deze gedeelde consensus over de wijze waarop de taal gefundeerd kon worden in de werkelijkheid via ostensieve definities, verschilden logisch empiristen van mening over de vraag wat nu precies het fundament voor kennis was. Sommigen verdedigden een fysicalistische opvatting, terwijl anderen zoals Carnap in dat deel van zijn werk het fundament in de subjectieve ervaring zochten.

Naast problemen rond de aard van de elementaire waarnemingsuitspraken, kampten logisch empiristen met problemen rond theoretische termen. Wetenschappelijke uitspraken bevatten theoretische termen die niet rechtstreeks verwijzen naar waarneembare fenomenen. Zulke uitspraken waren problematisch omdat zij niet voldeden aan het verificatie-principe en dus zouden wij moeten concluderen dat dergelijke uitspraken niet betekenisvol zijn. De leden van de Wiener Kreis probeerden deze problemen te ondervangen door de introductie van zogenaamde correspondentieregels, waarmee theoretische termen verbonden konden worden met observatietermen. Wanneer het mogelijk zou zijn zulke correspondentieregels te specificeren, dan kon alsnog een empirische betekenis aan theoretische termen worden gegeven. Lasti- 
ger was echter een hiermee samenhangende kwestie. Ook universele uitspraken woldoen niet aan het verificatie-criterium. De waarheid wan universele uitspraken kan immers nooit op grond van een eindig aantal waarnemingen worden vastgesteld. Dit zogenaamde inductie-probleem heeft Popper aangegrepen om het logisch empirisme te bekritiseren.

Poppers kritiek op het logisch empirisme behelst in feite twee punten. In de eerste plaats is inductie geen logisch geldige redeneervorm. Uit een eindig aantal uitspraken kan niet volgens logisch geldige regels een universele uitspraak worden afgeleid. Popper heeft het falsificatie-criterium als oplossing voor dit inductie-probleem aangedragen. Poppers tweede argument is kennistheoretisch van aard. Een fundament voor kennis is volgens. Popper afwezig aangezien er geen natuurlijk onderscheid bestaat tussen waarnemingsuitspraken en theoretische uitspraken. ${ }^{7}$ Wij theoretiseren volgens hem altijd, zelfs wanneer wij de meest triviale uitspraken doen. Wanneer iemand zegt: 'hier is een glas water', dan neemt hij impliciet allerlei veronderstellingen voor zijn rekening die universele uitspraken bevatten. Deze uitspraak bevat namelijk algemene begrippen als 'glas' en 'water' die worden gebruikt om zaken aan te duiden die een wetmatig karakter hebben en die daarom onze ervaring 'overstijgen'. Elke wet overstijgt deze ervaring volgens Popper omdat een wet nu eenmaal niet verifieerbaar is. Daarom zeggen wij altijd (impliciet) meer over de wereld dan ervaring 'toestaat' en hebben ogenschijnlijk triviale uitspraken als 'hier is een glas water' een hypothetisch karakter.

Popper trekt uit deze redenering de conclusie dat alle uitspraken theoretisch zijn en dat elke waarneming wordt verricht in het licht van een theorie. Deze epistemologische conclusie zet hij vervolgens om in een methodologisch advies: Popper verwacht dat onderzoekers in de wetenschappelijke praktijk conform de uit zijn epistemologie afgeleide deductieve methodologie werken. Deze latatste conclusie, zo bleek in hoofdstuk 2 en 3 , was niet met de onderzoekspraktijk in overeenstemming. In de onderzoekspraktijk kan naast een deductieve stijl een inductieve stijl worden onderscheiden. In de inductieve stijl worden eerst (nieuwe) fenomenen beschreven en feiten verzameld, die vervolgens in termen van een geaccepteerde theorie worden geïnterpreteerd. Deze activiteiten van onderzoekers die inductief te werk gaan zijn niet met behulp van Poppers Zoeklichttheorie te verklaren, omdat Popper een nauwe relatie legt tussen zijn epistemologie en methodologie. Popper heeft geen oog voor de mogelijkheid dat naast basisuitspraken andere uitspraken een essentiële rol kunnen spelen in de wetenschappelijke praktijk. Welke rol vervullen bijvoorbeeld representatie-methoden bij de beschrijving van fenomenen? Wat is de status van feiten in de 
inductieve stijl? Popper spreekt daar niet over. Ook op deze vragen kan het antwoord niet worden ontleend aan Poppers Zoeklichttheorie. Aan de hand van ideeën van de latere Wittgenstein zal worden beargumenteerd waarom we voor een antwoord niet meer te rade hoeven te gaan bij de logisch empiristische Emmertheorie.

\section{3}

\section{Regels zijn de maat van alle dingen ${ }^{8}$}

Voor een nadere analyse van de rol van feiten en representa-tiemethoden zijn twee problemen uit Wittgensteins filosofie van cruciaal belang die respectievelijk kunnen worden aangeduid als het probleem van de 'harmonie tussen taal en werkelijkheid' en het probleem van de 'verbinding tussen taal en werkelijkheid'. De oplossingen die Wittgenstein voor deze problemen heeft gegeven verschillen radikaal in de Tractatus Logico-Philosophicus en de Philosophische Untersuchungen." In de Tractatus gaf Wittgenstein een verklaring voor de 'harmonie tussen taal en werkelijkheid' met behulp van de afbeeldingstheorie en veronderstelde hij (impliciet) dat de 'verbinding tussen taal en werkelijkheid' werd gelegd via ostensieve definities. De antwoorden in de Philosophische Untersuchungen zijn op het eerste gezicht filosofisch gezien minder diepzinnig. De 'harmonie tussen taal en werkelijkheid' is dan een probleem waarvoor geen verklaring kan worden gegeven. De 'verbinding tussen taal en werkelijkheid' behoeft geen verklaring omdat er geen kloof is tussen taal en werkelijkheid. Maar, zoals ik zal laten zien, deze latere antwoorden zijn wel vruchtbaar. Deze beide veranderingen in Wittgensteins filosofie zal ik hier bespreken.

1 De verbinding tussen taal en werkelijkheid. In de Tractatus stelde Wittgenstein zich tot doel het wezen van de wereld bloot te leggen. Daarvoor analyseerde hij de essentie van de beschrijving, omdat onze kennis over de wereld wordt uitgedrukt in beschrijvingen. Wat essentieel is voor de beschrijving moest volgens Wittgenstein ook essenticel zijn voor de wereld. Zijn analyse kan als volgt kort worden samengevat. De taal bestaat uit proposities, die verder te analyseren zijn tot elementaire proposities. Zo'n elementaire propositie bevat elementen die niet verder te analyseren zijn, namelijk 'namen'. Proposities bestaan dus omgekeerd uit een aaneenschakeling van namen. Een naam vertegenwoordigt een object of: het object is zijn betekenis. Deze analyse bevat in feite de drie centrale thesen van het logisch atomisme: (1) een volledig geanalyseerde propositie bestaat uit eenvoudige namen die niet verder 
te analyseren zijn, (2) namen hebben geen Sinn maar alleen Bedeutung: ze verwijzen naar een object, en (3) de Sinn van een elementaire proposilie is een functie van haar constituerende uitdrukkingen. De combinatie van constituerende namen volgens syntactische regels vormt een logisch beeld van een mogelijke stand van zaken. Dat proposities een Sinn hebben wil dus zeggen dat zij een mogelijke configuratie van objecten weergeven. Proposities zijn bipolair, dat wil zeggen dat zij waar kunnen zijn en onwaar kunnen zijn.

Proposities vergeleek Wittgenstein met pijlen; zij hebben een richting die kan worden omgekeerd door de negatie-operatie. Indien de wereld is zoals de propositie zegt dat zij is, is de propositie waar; zo niet dan is de propositie onwaar - maar niet betekenisloos. Namen vergeleek Wittgenstein met punten, die geen richting hebben. Wanneer niets correspondeert met een naam, dan is de naam niet onwaar maar betekenisloos. De objecten die de betekenis van namen waren moesten volgens Wittgenstein bestaan, anders was het volgens hem niet duidelijk hoe wij onware proposities kunnen bedenken die toch betekenisvol zijn. De objecten moesten eenvoudige, onvernietigbare entiteiten zijn die de (metafysische) substantie van de wereld vormden. Eigenschappen, relaties, punten lijken kandidaten te zijn voor objecten, maar de auteur van de Tractatus deed hier geen duidelijke uitspraken over. ${ }^{10}$

Wanneer we de objecten laten voor wat zij zijn, blijft er niettemin nog wel een probleem liggen. Hoe worden namen met objecten 'verbonden'? In de Tractatus bespreekt Wittgenstein deze vraag niet expliciet, maar hij signaleert in zijn latere werk wel een probleem: de beschrijving van een object en de uitleg van een woord zijn incompatibel. ${ }^{11}$ De zin: 'dit is rood' kan niet tegelijkertijd een beschrijving zijn van een object en een uitleg van het woord 'rood'. Dat dit niet zomaar een probleem is, wordt duidelijk wanneer wij ons afvragen wat de rol van zinnen als 'dit is rood' was in de Tractatus. Impliciet veronderstelde Wittgenstein dat via ostensieve definities (bijvoorbeeld: 'dit is rood') een 'verbinding' werd gelegd tussen taal en werkelijkheid, tussen namen en objecten. Dat blijkt uit de gesprekken met Waismann, wanneer Wittgenstein het probleem al door heeft en zegt: 'Unklar im Traktat war mir die logische Analyse und die hinweisende Erklärung. Ich dachte damals, dass es eine "Verbindung der Sprache mit der Wirklichkeit gibt".,12 Dat via ostensieve definities ('hinweisende Erklärungen') een 'verbinding' tussen taal en werkelijkheid wordt gelegd is echter volgens de latere Wittgenstein een filosofische illusie.

Wittgensteins latere visie op ostensieve definities is onlosmakelijk verbonden met zijn kritiek op het logisch atomisme. Daar zijn een aantal ontwikkelingsstadia in aan te wijzen waarvan hier alleen het laatste 
stadium wordt besproken. De eerste these uit de Tractatus die Wittgenstein liet vallen was de these dat atomaire proposities logisch van elkaar onafhankelijk zijn. Dat kleurpredicaten zoals 'rood' en 'groen' elkaar uitsluiten genereert een interne relatie tussen elementaire proposities zodat zij niet logisch onafhankelijk zijn. Wittgenstein probeerde deze problemen in eerste instantie te ondervangen door de introductie van de notie 'Satzsystem' (systeem van proposities), maar ook die notie bleek geen adequate uitweg. De interne relaties zouden dan namelijk onafhankelijk van het gebruik van woorden en uitdrukkingen geduid worden en dat is volgens de latere Wittgenstein een misvatting. Wie via een 'Satzsystem' een oplossing zoekt voor de problemen rond interne relaties suggereert dat het elkaar uitsluiten van kleurwoorden onafhankelijk is van het gebruik van kleurwoorden. En die suggestie is in strijd met het feit dat we in het alledaagse leven iemands kennis van kleurwoorden afleiden uit zijn gebruik van woorden. Of iemand weet wat rood is, maken wij op uit het feit dat hij bijvoorbeeld een juiste ostensieve definitie kan geven. Dat kleurwoorden als 'groen' en 'rood' elkaar uitsluiten is juist een aspect van de praktijk van ostensieve definities. Wij gebruiken bijvoorbeeld een tomaat om het woord 'rood' uit te leggen. De tomaat heeft in deze praktijk een functie; die duiden we aan met het begrip 'sample'. In deze praktijk van ostensieve definities accepteren we niet dat iemand naar een 'sample' voor rood wijst wanneer het woord 'groen' moet worden uitgelegd. Dus is het elkaar uitsluiten een kenmerk van de wijze waarop wij kleurwoorden uitleggen en 'samples' gebruiken. Wanneer iemand een definitie kan geven, dan geeft hij er blijk van een woord correct uit te kunnen leggen. Of, algemener geformuleerd, ostensieve definities zijn regels die linguïstisch gedrag in banen leiden, die standaarden verschaffen voor wat correcte toepassingen zijn.

Dat ostensieve definities regels zijn en geen beschrijvingen heeft Wittgenstein uitgebreid beargumenteerd. ${ }^{13}$ Het prototype van een ostensieve definitie bestaat uit drie elementen: een aanwijzend gebaar, iets waarop wordt gewezen, en een verbale uitspraak ('dit is ...'). Wanneer iemand bijvoorbeeld het woord 'meter' wil uitleggen kan hij naar een meetlat wijzen en zeggen: 'de lengte van deze lat is een meter'. Zo'n ostensieve definitie is een gids voor ons taliggedrag en verschalt ons een standaard voor wat correcte toepassingen zijn. In die zin zijn ostensieve definities regels die behoren tot de grammatica van de taal. De vraag rijst natuurlijk hoe ostensieve definities regels kunnen zijn. Toepassingen van regels moeten toch gerechtvaardigd of bekritiseerd kunnen worden onder verwijzing naar een regel en dat lijkt in het geval van ostensieve definities nu juist niet mogelijk. Er is immers op het eerste gezicht geen relatie tussen een ostensieve definitie van een uitdrukking 
en de verdere toepassing ervan. Iemand wijst op een tomaat en zegt: 'dit is rood'. Vervolgens past hij de term 'rood' op een ander voorwerp toe en zegt: 'dat is rood". Aangezien het om twee onaftuankelijke uitspraken lijkt te gaan, is onduidelijk wat het verband tussen beide is. Gaat het hier on een wergelijking, zoals de logisch empiristen dachten? Dan zou iemand het eerste voorwerp als zijnde rood beschreven hebben en in dat geval is de uitspraak over het tweede voorwerp onafhankelijk van de eerste. De premisse is echter in deze redenering onjuist. Bij een ostensieve definitie wordt geen object als zijnde rood beschreven, maar wordt een uitleg gegeven van wat het wil zeggen dat willekeurig welk voorwerp rood is. Daarom is zo'n uitleg normatief gerelateerd aan de toepassing op andere voorwerpen. Wanneer iemand een ostensieve definitie toepast op een tweede voorwerp en zegt: 'dat is rood', dan bedoelt hij dat dat deze kleur heeft (dat wil zeggen de kleur van dit, namelijk rood). In deze zin zijn ostensieve definities relevant als regels, als standaarden voor toepassingen van uitspraken.

Niettemin, zo kan een criticus opmerken, blijft er wel een probleem liggen. Wanneer iemand zegt: 'dit is rood' en vervolgens deze ostensieve definitie toepast op andere objecten, dan wordt toch beweerd dat de kleuren van die andere objecten lijken op dit? Ook hier is de premisse in de redenering onjuist. Omdat een ostensieve definitie geen beschrijving is, wordt bij de toepassing op andere objecten ook niet dezelfde eigenschap toegeschreven die toegekend is aan de 'sample' bij de uitleg van 'rood'.

Hoe functioneren ostensieve definities dan wel als standaarden? Een ostensieve definitie is een substitutie-regel. Een ostensieve definitie maakt de substitutic mogelijk van een aanwijzend voornaamwoord samen met een gebaar dat een 'sample' aanduidt naar een verbale uitdrukking. Het is een regel waarmee een gebaren-taal vertaald wordt in een woord-taal (en vice-versa). In plaats van: 'deze tomaat is rood' kan iemand immers ook zeggen: 'deze tomaat is dit (terwijl hij wijst naar een'sample')'. De ostensieve definitie fungeert hier als substitutie-regel, omdat die de overgang mogelijk maakt van 'dat is dit (samen een gebaar dat de 'sample' aanduidt) naar 'dat is rood'. Maar als ostensieve definities substitutie-regels zijn, dan is de uitspraak 'deze tomaat is dit (met een aanduiding van de 'sample" voor rood)' hetzelfde als de uitspraak 'deze tomaat is rood'. Wat is dan de rechtvaardiging voor de uitspraak dat deze tomaat deze kleur heeft? Juist in dit geval wordt immers geen beroep gedaan op een regel? Wittgensteins antwoord op deze vraag is dat het noch gerechtvaardigd, noch ongerechtvaardigd is om zo'n uitspraak te doen. Wanneer wij een tomaat in het daglicht zien en zeggen dat die tomaat rood is, dan doen wij dat niet omdat wij daar een bewijs 
voor hebben. Zo'n oordeel heeft geen grond en bij gevolg rijst het rechtvaardigingsprobleem niet. Een ostensieve definitie als substitutieregel voorziet in deze zin niet in een standaard waarmee toepassingen kunnen worden gerechtvaardigd. Evenzo wordt de 'sample' voor rood niet gebruikt als standaard van vergelijking om te beslissen of andere objecten rood zijn. Hoe kan een ostensieve definitie nu functioneren als standaard voor correcte toepassingen? Deze vraag rijst niet meer wanneer wij onderkennen dat oordelen, waarin ostensief gedefinieerde uitdrukkingen worden toegepast, geen grond hebben. De presuppositie van deze vraag was onjuist; namelijk dat grammaticale regels slechts dan een normatieve rol kunnen vervullen indien met die regels de gronden voor het toepassen van uitdrukkingen kan worden gespecificeerd. Een ostensieve definitie van 'rood' legt echter niet uit hoe wij moeten zeggen dat iets rood is, maar wat het wil zeggen dat iets rood $i$. De verbinding tussen een ostensieve definitie en de toepassing ervan blijkt uit de praktijk, uit het gebruik van regels en het spreken van een taal. Wij gebruiken ostensieve definities als regels en beschouwen het feit dat iemand een correcte definitie van 'rood' kan geven als een criterium voor zijn begrip van 'rood'. Er is geen mechanisme dat specificeert hoe ostensieve definities zijn verbonden met de verdere toepassingen van ostensief uitgelegde woorden.

De functies die door de latere Wittgenstein aan ostensieve definities en 'samples' werden toegekend, verschillen uiteraard drastisch van de functies die ostensieve definities (impliciet) en simpele objecten in de Tractatus hadden. In de Tractatus verschenen de namen als noodzakelijke elementen van proposities: zij waren het eindpunt van de analyse van een propositie. Dus leken de objecten, die de betekenis van die namen waren, de substantie van de wereld te vormen. De objecten moesten noodzakelijk bestaan, als een voorwaarde voor de mogelijkheid van taal, anders konden wij ons die objecten niet voorstellen. Deze gedachtengang berustte volgens de latere Wittgenstein op een fundamentele misvatting. Ostensieve definities zijn volgens hem geen toepassingen van woorden op objecten waarmee taal vastgepind wordt in de werkelijkheid. Het zijn regels waarmee objecten in het symbolisme van de taal worden 'getrokken' door die objecten als 'samples' te gebruiken. Met ostensieve definities worden woorden binnen de taal uitgelegd: met die regels wordt een woord-taal vertaald in een gebaren-taal (en vice versa). Deze opvatting moet niet verkeerd worden geïnterpreteerd. Ontkend wordt niet dat uitdrukkingen kunnen refereren naar buitentalige entiteiten. Ontkend wordt dat er een niveau moet zijn waarop de analyse van talige uitdrukkingen eindigt en dat dit niveau als fundament voor kennis zou kunnen dienen. Wittgensteins opvatting op dit punt 
behoort tot zijn algemene doctrine: 'de autonomie van de grammatica'. Ostensieve definities misleiden ons volgens Wittgenstein omdat zij de vorm hebben van een beschrijving. Dus lijken zij woorden met objecten te verbinden. "Dit is rood' lijkt op de empirische uitspraak 'deze stoel is rood'. Maar de ogenschijnlijke overeenkomst werdwijnt snel wanneer wij de ostensieve definitie parafraseren en zeggen: 'deze kleur (met een aanduiding van een sample) is rood'. Het is immers geen contingent feit dat deze kleur (namelijk rood) rood is. Wanneer iemand op een object wijst, de betekenis van het woord 'rood' wil uitleggen, en zegt: 'dit is rood', dan zegt hij niet iets over het object. De sample vervult hier de rol van een instrument van de taal en behoort tot de representatiemethode. Of iets een sample is, hangt af wan het gebruik en is geen kenmerk van een object. Er is geen kloof tussen taal en de wereld; wel een onderscheid tussen de representatie-methode en dat wat wordt gerepresenteerd.

2 De harmonie tussen taal en werkelijkheid.14 Wittgensteïns latere ideeën over de rol van ostensieve definities en samples kunnen worden gebruikt om beschrijvend en experimenteel onderzoek nader te analyseren. We hebben niet meer de Emmertheorie met haar onverdedigbare epistemologische lading nodig om te verklaren waarom onderzoekers fenomenen beschrijven, samples gebruiken, etcetera. Naast het beschrijven van fenomenen verrichten onderzoekers ook andere, typische empiristische activiteiten. Vaak beweren onderzoekers 'feiten te verzamelen'. Welke status hebben 'feiten' hier? Een antwoord kunnen we ontlenen aan Wittgensteins latere visie op de 'harmonie tussen taal en werkelijkheid'.

In de Tractatus probeerde Wittgenstein met de afbeeldingstheorie de 'harmonie tussen taal en werkelijkheid' te verklaren. De kern van de afbeeldingstheorie was dat wij modellen (en in het specifieke geval proposities) maken van standen van zaken. Wij kunnen die proposities begrijpen zonder te weten of die proposities waar zijn of onwaar. Wat wij dan begrijpen kan geen feit zijn, want dan zou het niet mogelijk zijn om onware proposities te begrijpen. Omgekeerd moeten we weten wat het geval moet zijn indien een propositie waar is. Wij kunnen als het ware aan een propositie zien welk feit de propositie waar maakt. In die zin anticipeert een propositie de wereld. Maar hoe kan een propositie de wereld anticiperen? In de Tractatus gaf Wittgenstein als antwoord dat een propositie een beeld bevatte van een mogelijke stand van zaken. Elementaire proposities waren zelf feiten die, vanwege hun structuur, mogelijke standen van zaken afbeelden. Indien die mogelijke standen van zaken werden geactualiseerd waren die proposities waar. Proposi- 
ties bepaalden als het ware de werkelijkheid behalve op een 'ja' of een 'nee'. Alleen zo kon volgens Wittgenstein worden verklaard hoe wij kunnen weten wat het geval moet zijn indien die propositie waar is, en hoe het mogelijk is dat wij kunnen denken wat niet het geval is.

De relatie tussen een ware propositie en het feit dat die propositie waar maakt was volgens de auteur van de Tractatus een interne relatie. Het is niet denkbaar dat, wanneer de mogelijke stand van zaken (die door de propositie wordt afgebeeld) wordt geactualiseerd, de propositie toch niet waar is. De afbeeldingstheorie was met andere woorden een versie van de correspondentie-theorie van de waarheid met dien verstande dat de correspondentie-relatie een interne is en dus onuitsprekelijk. ${ }^{15}$

In zijn latere filosofie handhaafde Wittgenstein de gedachte dat er een interne relatie is tussen een ware propositie en het feit dat de propositie waar maakt. Hij voegde er echter een nieuw element aan toe: een interne relatie is niet verder te analyseren. Tot deze conclusie kwam hij naar aanleiding van een analoog probleem: de relatie tussen een verwachting en de vervulling van die verwachting. Ook voor die relatie geldt immers dat men aan de verwachting kan 'zien' wat de vervulling is van die verwachting. De verwachting anticipeert de vervulling ervan, lijkt een beeld te bevatten van de vervulling van de verwachting (natuurlijk bevat de verwachting niet de gebeurtenis, want de verwachting wordt niet altijd vervuld). De verwachting dat $A$ komt wordt vervuld door het feit dat $A$ komt. Hoe kan een verwachting de vervulling ervan anticiperen? Het lijkt dat de verwachting de vervulling ervan anticipeert doordat de verwachting een beeld bevat van een mogelijkheid ('mogelijke standen van zaken'), net zoals een elementaire propositie een beeld bevat van een mogelijke situatie zodat die propositie zich als een 'blueprint' tot de wereld verhoudt. Maar precies op dit punt worden we volgens de latere Wittgenstein misleid door de grammatica. De interne relatie tussen een verwachting en de vervulling ervan kan immers niet verder worden geanalyseerd. Wat een metafysische verbinding lijkt tussen twee verschillende typen entiteiten is een interne relatie die niet verder kan worden geanalyseerd. Wanneer ik verwacht dat A om 12.00 komt dan verwacht ik dat $A$ (en niemand anders) op dat tijdstip komt (en niet vroeger of later). Dat is precies wat met de verwachting werd uitgedrukt. De verbinding tussen een verwachting en de vervulling ervan wordt in de taal gelegd, namelijk: 'de verwachting dat p' = "de verwachting die wordt vervuld door de gebeurtenis p'. Precies dezelfde metafysische illusie speelde Wittgenstein parten in de Tractatus bij de relatie tussen een propositie en een feit. Dat een propositie de wereld anticipeert zegt niets meer dan dat de propositie 'p' bepaalt dat $p$ het geval moet zijn wil 
de propositie waar zijn. Ook hier gaat het niet om twee entiteiten die tot verschillende 'domeinen' behoren, namelijk Taal en Wereld.'De propositie dat $\mathrm{p}^{\prime}=$ 'de propositie die het feit dat $\mathrm{p}$ waar maakt', en 'het feit dat $\mathrm{p}^{\text {' }}$ = 'het feit dat de propositie dat $\mathrm{p}$ waar maakt'. De bewering dat een propositie waar is indien die propositie correspondeert met de felten is in Wittgensteins latere filosofie dan ook geen metafysische waarheid over de relatie tussen taal en werkelijkheid. Zo'n bewering is wel correct, maar het is een grammaticale uitspraak. In plaats van 'p is waar' kunnen wif immers ook zeggen 'het is een feit dat $p$ ', of 'p correspondeert met de feiten' of 'de dingen in de werkelijkheid zijn zó zoals de propositie dat p beschrijft dat zij zijn', of gewoon ' $p$ '.

In zijn latere fillosofie werwierp Wittgenstein dus de afbeeldingstheorie. De 'harmonie tussen taal en werkelijkheid" hoeft volgens hem niet verklaard te worden en kan ook niet worden verklaard omdat de grammatica van de taal autonoom is. In plaats van de afbeeldings-theorie komt in zijn filosofie dan de 'autonomie van de grammatica'. Waarom is de grammatica van de taal niet te rechtvaardigen onder verwijzing naar de werkelijkheid? Wittgenstein heeft de poging om de grammatica van de taal te rechtvaardigen onder verwijzing naar de werkelijkheid vergeleken met de poging om een propositie te rechtvaardigen onder verwijzing naar datgene wat de propositie waar maakt. Waarom kan een propositie niet worden gerechtvaardigd onder verwijzing naar natuurfeiten? Stel dat iemand de propositie 'A is rood' will rechtvaardigen onder verwijzing naar het feit dat $A$ rood is. Ten eerste: de propositie kan niet worden gerechtvaardigd door te wijzen naar een feit. ${ }^{16}$ Feiten bevinden zich namelijk niet in de wereld. (Het is een feit dat Amsterdam in Nederland ligt, maar dat feit ligt niet in Nederland of in Engeland). Wel kan iemand wijzen op het feit dat $A$ rood is. Ten tweede: het feit dat $A$ rood is, is alleen een bewijs wanneer iemand weet dat $A$ rood is. Dat wat als rechtvaardiging telt wordt door de propositie voorondersteld. ${ }^{17}$ Een voorbeeld kan dit verduidelijken. ${ }^{18}$ Omdat wij vier primaire kleuren onderscheiden, zijn wij geneigd te denken dat dit juist is omdat er vier kleuren zijn. Dit zou als rechtvaardiging kunnen tellen wanneer het betekeniswol was om over een vijfde primaire kleur te spreken. Maar dat wordt nu juist door onze grammatica van kleurwoorden uitgesloten! Het is niet onjuist om te stellen dat er een vijfde primaire kleur is; dat is met onze huidige grammatica voor kleuren niet betekenisvol. Dus zal een rechtvaardiging, waarin gebruik wordt gemaakt van een vijfde primaire kleur, onder het begrip 'primaïre kleur' iets anders verstaan. Maar dan kan die rechtvaardiging niet ons begrip rechtvaardigen.

De conclusie die hieruit kan worden getrokken is dat de grammatica van de taal niet te rechtvaardigen is onder verwijzing naar natuurfeiten. 
Dit lijkt dramatische gevolgen te hebben: wanneer er geen rechtvaardiging kan worden gegeven, en er dus ook geen conflict mogelijk is tussen taal en werkelijkheid, dan lijken de grammaticale regels volkomen arbitrair te zijn. Spelen de naturfeiten dan geen enkele rol?

Natuurfeiten maken onze begrippen niet waar, maar spelen terdege een rol: zij vormen de achtergrond condities voor het gebruik van begrippen. Wanneer de wereld niet (relatief) stabiel was, dan zouden wij bepaalde begrippen niet gebruiken. Stel dat we nooit onveranderlijke kleuren zouden zien of dat het zonlicht infrarood was, dan zouden onze huidige kleurwoorden niet meer bruikbaar zijn. Niet omdat zij dan onjuist zouden zijn, want de relatieve stabiliteit van de wereld is geen onderdeel van het gebruik van begrippen, net zoals het geen onderdeel is van het tennisspel dat het gravitatieveld op aarde relatief constant is. Wij kunnen met andere woorden onder 'normale omstandigheden' begrippen gebruiken hoewel dat niet vereist dat wij precies kunnen zeggen welke die normale omstandigheden zijn. Maar omgekeerd kunnen we wel precies zeggen hoe situaties, waarin het gebruik van begrippen twijfelachtig wordt, afwijken van de normale omstandigheden.

Grammaticale regels zijn autonoom omdat zij niet te rechtvaardigen zijn onder verwijzing naar de werkelijkheid. Hieruit volgt dat grammaticale regels geen theorie inhouden over de wereld; grammaticale regels bepalen wat betekenisvol is maar zeggen niets over de feiten. Met grammaticale regels kunnen empirische proposities en beweringen worden gevormd die waar of onwaar kunnen zijn. Wij kiezen voor bepaalde grammaticale regels op grond van hun bruikbaarheid en daarvoor kunnen wij redenen en argumenten geven. Daarbij gaat het natuurlijk voor een belangrijk deel om regels uit het 'alledlaagse' leven, maar vooral in de wetenschap kunnen we natuurlijk verwachten dat er voortdurend nieuwe regels worden ontworpen ondat met de theorieën, die in termen van die grammaticale regels kunnen worden uitgedrukt, nieuwe voorspellingen en verklaringen kunnen worden gegeven. In de relativiteitstheorie worden de begrippen 'ruimte' en 'tijd' anders gebruikt dan in het alledaagse leven en de Newtoniaanse fysica en daar zijn specifieke argumenten voor te geven. $\mathrm{Na}$ het werk van Kuhn en anderen valt natuurlijk meér te zeggen over de rol van grammaticale regels in theorieën. Wittgenstein heeft hier weinig over geschreven en daarom beperk ik mij in dit hoofdstuk tot de rol van 'alledaagse' grammaticale regels. Deze regels zullen in de lokale onderzoekspraktijk een belangrijke rol spelen. $^{19}$ 


\section{Samples}

Wittgensteins latere ideeën over de 'verbinding tussen en taal en werkelijkheid' en de 'harmonie tussen taal en werkelijkheid' kunnen worden gebruikt om het karakter van empirisch onderzoek nader te analyseren. In tegenstelling tot wat men op grond van Poppers Zoeklichttheorie zou moeten concluderen, kunnen we nu beargumenteren waarom (in methodologisch opzicht) niet alle uitspraken als hypothetische uitspraken functioneren. Wanneer iemand bijwoorbeeld een representatiemethode gebruikt, dan verricht hij geen theoretische activiteiten, want als het theoretische activiteiten waren, dan zou het mogelijk moeten zijn dat de gebruikte theorieën onjuist zijn en dat is op dit niveau nu juist niet mogelijk. Natuurlijk kan iemand een fout maken bij het gebruik van een representatiemethode. Zo'n fout is echter geen weerlegging van een hypothese maar eerder een aanwijzing voor het feit dat er bepaalde representatie-methoden worden gebruikt. Met Poppers Zoeklichttheorie kan het functioneren van representatiemethoden niet worden verkllaard.

Op grond van Wittgensteins filosofie kunnen we verwachten dat met name grammaticale regels en samples een belangrijk onderdeel vormen van het wetenschappelijk handelen. Welke regels onderzoekers gebruiken zal afhangen van het wetenschapsgebied dat wordt onderzocht. We zullen verschillende regels aantreffen bij biologen die onderzoeken wat mensen en dieren waarnemen, ethologen die de expressies van emoties bestuderen, en medici die diagnoses stellen. $\mathrm{Zij}$ maken gebruik van verschillende grammaticale regels in het empirisch onderzoek. Het is voor een dokter betekenisvol om aan een patiënt te vragen waar hij pijn heeft, want sensaties hebben een locatie. Daarom is het bij een diagnose belangrijk om te weten of die locatie correspondeert met plekken bij andere patiënten (dat noemen wij 'dezelfde pijn hebben'). Emoties hebben daarentegen geen locatie in het lichaam; emoties bevinden zich in een andere 'logische ruimte'. Emoties hebben karakteristieke uitdrukkingen in het gedrag en die uitdrukkingen worden door ethologen onderzocht. Of levende wezens bepaalde objecten kunnen waarnemen bestuderen wetenschappers aan de hand van het gedrag van die wezens. Hoe reageren zij op bepaalde kleuren, geuren of geluiden; hoe gebruiken zij hun zintuigen bij het onderscheiden van objecten? Het gedrag van dieren en mensen levert de (logische) rechtvaardiging voor de beantwoording van de vraag wat dieren en mensen waarnemen. Waarnemen wil zeggen dat mensen (en dieren) organen (ogen, oren) gebruiken waarmee zij waarnemen. Wij oriënteren onze ogen (en ons hoofd) 
wanneer we de omgeving onderzoeken, volgen vogels met onze ogen, brengen objecten dichter bij om ze beter te kunnen waarnemen. En zo verkrijgen wij kennis over onze waarneembare omgeving. Uit het gedrag van mensen maken wij met andere woorden op of zij iets kunnen waarnemen.

Naast regels kunnen we verwachten dat vooral samples een centraal element vormen van empirisch onderzoek. ${ }^{20}$ Op grond van Wittgensteins latere ideeën kunnen we verwachten dat samples, als onderdeel van representatiemethoden, gebruikt worden bij het beschrijven, classificeren en analyseren van fenomenen. Welke rol vervullen samples in de taal?

Het woord 'sample' is verwant aan andere woorden die woor standaarden van vergelijking worden gebruikt, zoals "paradigma', 'patroon', 'staaltje', 'model', 'type' en 'monster'. Ik gebruik hier de term 'sample' als vertaling van de Duitse term 'Muster', aangezien het om een technische term gaat.

Samples zijn bruikbaar als standaarden van vergelijking. Opgezette dieren in een museum kunnen bijvoorbeeld functioneren als samples van biologische soorten. Zo'n sample wordt gebruikt als standaard om andere leden van de soort te identificeren. Op dezelfde wijze functioneren samples van fossielen als standaarden van vergelijking in de paleontologie, en foto's of tekeningen van gedragspatronen als samples in de ethologie. $\mathrm{Zij}$ worden voornamelijk in beschrijvend onderzoek gebruikt. Voorbeelden van samples in experimenteel onderzoek zijn bodemmonsters of watermonsters in chemisch onderzoek, of bloedmonsters of samples van stoffen uit de urine bij fysiologisch onderzoek. Zulke samples worden vaak verder experimenteel geanalyseerd.

Of iets een sample is hangt af van hoe iets wordt gebruikt. Iets een sample noemen wil zeggen dat de rol van de sample wordt gekarakteriseerd en die is niet te herleiden tot een 'intrinsiek kenmerk' van de sample. Wanneer samples worden gebruikt als samples, dan gaan zij functioneren als standaarden van vergelijking waarmee juiste en onjuiste toepassingen kunnen worden onderscheiden.

Het functioneren van samples kan op drie manieren verder worden gekarakteriseerd: (1) een sample is representatief voor datgene waarvan het een sample is; (2) een sample kan worden gecopieerd en gereproduceerd; (3) een sample heeft een normatieve rol, dat wil zeggen dat hij functioneert als standaard van vergelijking. Een sample functioneert als representatie-norm waarmee kan worden beoordeeld of hij correct wordt gecopieerd of gereproduceerd. De wijze waarop samples als representatie-normen functioneren is bekend: wanneer iemand een schilder vraagt iets te schilderen en hem een kleur-sample geeft bij het 
schilderwerk, dan faalt de schilder en niet de sample indien hij de sample slecht copieert. Baker en Hacker hebben als aanvulling op Wittgensteins werk drie verschillende manieren onderscheiden waarop samples in de taal functioneren: ${ }^{21}$

(1) Canonieke samples; sommige objecten hebben een unieke rol bij het toepassen van begrippen en zijn niet vervangbaar, zoals de standaardmeter en het standaardkilogram. Deze canonieke samples worden natuurlijk niet dagelijks gebruikt omdat zij niet voorhanden zijn. Wij gebruiken copieèn in het dagelijks leven en doen alleen in uitzonderlijke gevallen een beroep op deze samples.

(2) Standaard samples, ofwel: standaarden van vergelijking. Meetlatten, gewichten, kleurkaarten, stemvorken zijn voorbeelden.

(3) Facultatieve samples. Deze objecten spelen een belangrijke rol in het dagelijks leven maar niet noodzakelijk binnen een institutie. Bijvoorbeeld woorden als 'rood', 'zoet', 'warm' en 'hard' worden met behulp van facultatieve samples uitgelegd, zoals een rijpe tomaat voor het begrip 'rood'.

Het copiëren en reproduceren van samples is afhankelijk van de technieken die voorhanden zijn. Wat telt als copie kan met andere woorden veranderen wanneer technieken veranderen. In de zestiende eeuw bijwoorbeeld gebruikten paleontologen bij het copiëren en reproduceren van fossielen houtsneden. Eind zestiende en begin zeventiende eeuw ging men over op kopergravures amdat daarmee preciezere copieën mogelijk werden. ${ }^{22}$ De met kopergravures gemaakte copieën waren minder ambigu waardoor er steeds minder twijfel rees over de afbeeldingen. Op zich waren twijfelgevallen natuurlijk niet problematisch, omdat in die gevallen een beroep kon worden gedaan op de samples: de in musea of kabinetten bewaarde fossielen. Copieën zijn in bepaalde contexten bruikbaar, maar kunnen de samples niet vervangen.

Het copiëren en reproduceren van samples resulteert in specifieke afhankelijkheidsrelaties tussen onderzoekers. Eerst wisselden paleontologen samples uit of bezochten zij de kabinetten van anderen. Door samples te copiëren ontstonden nieuwe netwerken waardoor het oorspronkelijk lokale karakter van paleontologische kennis werd 'opgeheven'. Eerst door briefwisselingen; later via tijdschriften. Fossielen die op bepaalde pllaatsen te vinden waren konden nu via de copieën in principe overal worden onderzocht, waardoor onderzoekers niet langer afhankelijk waren van wat er lokaal werd gevonden. Dit resulteerde met andere woorden in specifieke samenwerkingsverbanden tussen onderzoekers.

Dit ontwikkelingspatroon, van lokale naar globaal toegankelijke (en dus kritiseerbare) kennis, vinden we ook in de levenswetenschappen in 
de zeventiende en achttiende eeuw, hoewel daar natuurijik andere samples centraal stonden. Botanici legden tuinen aan of droogden planten die als samples gingen functioneren; zoölogen stalden de skeletten uit van dieren in een museum of zetten dieren op. Tekeningen (nást beschrijvingen) vormden ook in deze vakken een belangrijke copieervorm. Het copièren van samples zegt op zich natuurlijk weinig over het doel dat men daarbij voor ogen heeft. Samples van planten kunnen gecopieerd en gereproduceerd worden in verband met hun geneeskundige werking. Botanici gingen in de achttiende eeuw samples copiëren met het oog op classificatie, net zoals paleontologen dat eerder met fossielen hadden gedaan. Het copiëren van samples kan ook het cultiveren van organismen tot doel hebben, zoals in microbiologie, of met als doel experimentele analyse, zoals in de chemie. Binnen de wetenschap zal het doel waarvoor samples worden gebruikt en de wijze waarop dat gebeurt natuurlijk afhangen van empirische puzzels. Het classificeren van fossielen, planten en dieren had vór en na Darwin een totaal ander doel. Pogingen om met behulp van classificaties de 'essenties' van soorten op te sporen zijn voor populatiegenetici zinloze ondernemingen geworden. ${ }^{23}$ Gegeven bepaalde achtergrondkennis zullen samples een specifieke functie vervullen, maar die functie kan veranderen wanneer de achtergrondkennis verandert.

Het reproduceren en copiëren van samples in tijdschriften is een onderdeel van het mobiel maken van 'objecten' in de wetenschap. Voortdurend zijn onderzoekers bezig centra in te richten waar 'objecten' op een overzichtelijke wijze worden geordend. Tijdens expedities bijvoorbeeld namen (en nemen) onderzoekers dieren, planten, mineralen, etcetera mee die zij vervolgens verder onderzoeken door ze, in de woorden van Latour, te combineren. ${ }^{24}$ Tal van activiteiten in de wetenschap zijn erop gericht de mobiliteit, stabiliteit en combineerbaarheid van de verzamelde 'objecten' te vergroten. Deze activiteiten zijn zeer heterogeen: de drukpers, die de mobiliteit en nauwkeurige copieën bevordert; flessen, om samples van diersoorten in te bewaren; kleurstoffen om bacteriën zichtbaar te maken. In de 'rekencentra', waar de 'objecten' bijeen worden gebracht, kan men vervolgens de verzamelde samples classificeren of met behulp van onder andere statistiek verder ordenen.

Door samples te reproduceren en copiëren zorgen onderzoekers voor continuiteit in de 'empirische basis'. In hoofdstuk 2 kwamen we al een voorbeeld tegen: Florey c.s. makkten gebruik van een sample van Flemings Penicillium-cultuur. Bij de ontdekking van het HIV-virus door Montagnier en Gallo speelde de uitwisseling van samples eveneens een cruciale rol. Omdat Gallo volgens Conner en Kingman werkte met een 
sample uit het laboratorium van Montagnier, ontdekte ook hij het Aids-virus. ${ }^{25}$ Of samples al dan niet gemakkelijk kunnen worden uitgewisseld hangt af van hun 'mobiliteit' en die varieert per vakgebied. Voor meten en wegen bestaat een geïnstitutionaliseerde praktijk waarbij wiij over de gehele wereld gebruik maken van copieën van de standaardmeter of het standaardkilogram. In de chemie kunnen met name synthetisch geproduceerde samples van stoffen gemakkelijk worden 'gemobiliseerd"; in de microbiologie cultiveert men bacteriën op petrischalen die worden uitgewisseid. In de zoölogie is het uitwisselen van samples van levende dieren moeilijker en zijn het vaak de onderzoekers die de samples 'bezoeken'. Het copiëren van samples door middel van tekeningen of foto's vormt hier de belangrijkste copieervorm die zorgt voor continuiteit in de 'empirische basis'. Een vereiste voor deze praktijk is natuurlijk een ontwikkelde boekdrukkunst of fotografie.

Omdat samples, doordat zij worden gecopieerd en gereproduceerd, zorgen voor continuiteit in de 'empirische basis', suggereert het gebruik van samples dat er een hecht fundament voor kennis is. De methodologische praktijken rondom samples vertonen overeenkomsten met praktijken die volgen uit de empiristische filosofie en zijn vermoedelijk ook een inspiratiebron geweest voor die filosofie. Volgens de Emmertheorie zijn zuivere waarnemingen de bron voor kennis, waarbij fouten in de waarnemingen een lokaal karakter hebben, en zijn fouten in de kennis te wijten aan onzorgvuldige verwerking van die zuivere waarnemingen. Wanneer de praktijken rondom samples en regels voor continuiteit in de empirische basis zorgen, dan keren elementen van dit empiristisch beeld in een andere gedaante terug en kan tevens worden verklaard waarom die elementen in het logisch empirisme gangbaar waren. ${ }^{26}$

Ten eerste heeft twijfel binnen de praktijk rondom samples en regels een lokaal karakter. Men kan volgens Wittgenstein niet de regels in twijfel trekken, want dan vraagt men in feite om een nieuwe notatie. Maar dat wil natuurlijk niet zeggen dat ten aanzien van het gebruik van samples en regels bij tijd en wijle geen conflict rijst en interpretatie-problemen voorkomen. Die zijn volgens Wittgenstein mogelijk juist omdat er consensus is over het gebruik van samples en regels. Het gebruik van samples en regels suggereert met andere woorden een zeker, onbetwijfelbaar fundament, maar dat is slechts schone schijn. Twijfel en zekerheid zijn begrippen die een functie hebben binnen een bepaalde regelgeleide praktijk.

Ten tweede kan met Wittgensteins latere ideeën worden verklaard waarom het gebruik van een visuele taal zo'n prominent onderdeel vormt van artikelen geschreven in de traditie van de inductieve stijl. De nadruk op zuivere waarnemingen lijkt centraal te staan, maar is in feite 
een afgeleide van het gebruik van samples en regels omdat samples ten grondslag liggen aan de 'waarnemingspraktijken'. Het gebruik wan uitspraken als: 'dit lijkt op ..., 'ik zie dat ...', etcetera, vooronderstelt begrippen waarmee kan worden uitgelegd dat het zus-of-zo-is. Consensus over regels en samples ligt met andere woorden aan de basis van die visuele taal. Wie het gebruik van bijvoorbeeld het begrip 'rood' kent, dus een sample voor rood kan gebruiken, kan uitspraken doen als 'ik zie dat dit rood is" of 'dit lijkt rood". De visuele taal is parasitair op het gebruik van samples en regels, maar ligt niet ten grondslag aan empirische kennis zoals de empirist dacht. De zaak ligt precies omgekeerd: het kunnen gebruiken en toepassen van samples en regels gaat vooraf aan de 'waarnemingsuitspraken'.

Ten derde kan aan de hand van het verschil tussen een 'empirisch bewijs' en - wat kan worden genoemd - 'witnessing' inzichtelijk worden gemaakt waarom verslagen van zintuiglijke waarnemingen zo'n centrale rol innemen in inductieve rechtvaardigingspraktijken. ${ }^{27}$ 'Omdat de straat nat is', is een bewijs voor: 'het regent'. Maar: 'ik weet dat het regent omdat ik het hoor' is geen bewijs omdat mijn waarnemingen mij geen bewijs leveren. Wel kan het als verslag voor iemand anders als bewijs functioneren mits ik een betrouwbare getuige ben. Verslagen van zintuiglijke ervaringen zullen met andere woorden precies en betrouwbaar moeten worden weergegeven, zodat de beschreven waarnemingen in die verslagen als bewijs voor anderen kunnen functioneren. Ook hiervoor geldt dat verslagen van waarnemingen suggereren dat die waarnemingen het fundament vormen voor kennis en daardoor wordt de empirist opnieuw misleid.

Wittgensteins latere ideeën over samples en regels suggereren dus een empiristische methodologische praktijk. Niettemin zijn de empiristische ideeën in Wittgensteins filosofie verdwenen. $\mathrm{Er}$ is geen zeker fundament voor kennis, herkenning is niet de grondslag van empirische kennis, er is geen kloof tussen taal en wereld, etcetera. Het empiristisch standaardbeeld kan niet langer als rechtvaardiging functioneren voor de praktijken rondom samples en regels. De overeenkomsten tussen Wittgensteins latere ideeën en het empirisme liggen op het vlak van de daadwerkelijke consequenties in de methodologische praktijk, de verschillen op het vlak van de rechtvaardiging die wordt gegeven voor die praktijk. Het empirisme als epistemologische theorie ter rechtvaardiging van de praktijk rondom samples en regels is onhoudbaar.

Deze verschillen tussen Wittgensteins ideeën en het traditionele empirisme stellen ons in staat de beschrijving van de ontwikkelingen binnen de gedragsembryologie nader te preciseren. In hoofdstuk 3 is benadrukt dat onderzoekers over concrete onderzoeksresultaten rela- 
tief eenvowdig tot overeenstemming konden komen, $_{3}$ hoewel de globale tegenstelling tussen aanleg en omgeving bleef bestaan. De nadruk van onderzoekers op experimenteel realisme en precieze waarnemingen suggereerde dat overeenstemming ower concrete onderzoeksresultaten mogelijk was omdat op dat niveau 'de feiten voor zich spraken'. Tevens suggereerde de ontwikkelingen binnen de gedragsembryologie dat er onderscheid kon worden gemaakt tussen waarnemingsuitspraken en theoretische uitspraken. Theoretisch speculeren werd immers veracht omdat men daardoor gemakkelijk weer verviel in de oude, theoretische tegenstelling tussen aanleg en omgeving. Voor de verklaring van de ontwikkelingen in de gedragsembryologie, zo leek het, was een terugkeer naar de logisch-empiristische leerstellingen onvermijdelijk. Met de in dit hoofdstuk ontwikkelde ideeën kunnen we nu een alternatief voor de empiristische verklaring geven. De verachting van theoretisch speculeren en het verheerlijken van precieze waarnemingen kan nader worden verklaard met behulp van het sample- en regelbegrip. In de lokale onderzoekssituatie, waarin onderzoekers met behulp van samples en regels "de natuur" prepareren, verricht men onderzoek op een niveau waarop de terminologie van de twee oudere hypothesen als het ware gezuiverd zijn van hun oorspronkelijk Zoeklicht- en Emmer-connotatie. Op dat niveau bestaat de oude tegenstelling niet in de experimentele setting omdat de onderzoeksresultaten goeddeels in termen van samples en regels kunnen worden beschreven. Fouten die onderzoekers op dit niveau maken kunnen worden geduid in termen van fouten bij het gebruik van samples of regels en hebben dus een lokaal karakter. Aan de hand van het onderzoek van Gottlieb kan dit worden geillustreerd.

Gottlieb onderzocht het discriminatie-vermogen van onder andere pekingeenden. De term 'vermogen' verwijst nog naar de Zoeklichttheorie, maar in het experiment speelt die geen rol omdat het ging om de ontwikkeling van dat vermogen. Dat geldt evenzeer voor de term 'zelfprikkeling' die ook niet meer betrekking had op empiristisch 'leren' in de zin van de Emmertheorie. Zelfprikkeling kan methodologisch worden vertaald door de geluiden die embryo's produceren met ostensieve definities uit te leggen. Gottliebs experimenten zijn met andere woorden het resultaat van puzzeloplossen waarbij 'de natuur' steeds verder is geprepareerd. Wat wil dat laatste hier zeggen? Daarvoor moeten we in detail de experimenten met behulp van de noties samples en regels analyseren. Om de ontwikkeling van het discriminatie-vermogen te onderzoeken, observeerde Gottlieb het gedrag van de kuikens in een experimentele situatie. Of zij bijwoorbeeld de lokroep van verschillende soorten konden onderscheiden, testte hij in keuze-situaties uit. Deze 
test vooronderstelt een alledaagse regel voor het begrip "waarnemen", namelijk dat wij, door hun gedrag te observeren, op grond wan het gedrag van dieren en mensen beslissen of zij iets kwrinen waarnemen. De ontwikkeling van dit discriminatie-vermogen beïnloedde Gottlieb door de embryo's tijdelijk stemloos te maken. Ook hier geldt dat er regels en samples in het geding zijn: het geluid dat embryo's produceren kan met een ostensieve definitie worden uitgelegd ('luister, dit is ...') en ook hier geldt dat de effecten van de experimentele ingreep worden opgemaakt uit de veranderingen in het gedrag (namelijk, of de embryo's de lokroep nog kunnen onderscheiden). Het onderzoek van Gottlieb is met andere woorden een voorbeeld van een experiment waarin precies de rol van regels en samples kan worden aangewezen en waarin fouten te relateren zijn aan het gebruik van specifieke representatie-methoden.

Wat deze analyse laat zien is, dat in de lokale onderzoekssituatie een concreet niveau is aan te wijzen, waarin het metaforisch, speculatief taalgebruik naar de achtergrond is verdwenen en waar samples en regels centraal zijn komen te staan. Het gebruik van samples en regels zorgt ervoor dat onderzoekers het relatief eenvoudig eens kunnen worden over bepaalde onderzoeksresultaten. Door voortdurend met behulp van samples en regels 'de natuur' te prepareren, worden er resultaten geboekt die tegenstanders steeds moeilijker kunnen negeren en die uiteindelijk overeenstemming kunnen bewerkstelligen.

Wittgensteins sample- en regel-begrip stelt ons in staat een preciezere analyse te geven van de lokale onderzoekspraktijk. De bruikbaarheid van deze begrippen voor nadere analyses van het aanleg-omgeving vraagstuk zal in de volgende hoofdstukken nog uitgebreid aan de orde komen. Voordat ik daartoe overga, zal ik eerst deze begrippen gebruiken om twee centrale wetenschapstheoretische problemen te verhelderen. In de eerste plaats de rol die samples en regels vervullen bij het oplossen van puzzels, en in de tweede plaats de rol die zij vervullen bij de interacties tussen de deductieve en inductieve stijl.

\section{5 \\ Samples, regels en puzzeloplossen}

Normale wetenschap, in de Kuhniaanse betekenis, bestaat uit drie soorten activiteiten. ${ }^{28}$ In de eerste plaats verzamelen onderzoekers feiten. Zo bepalen zij bijvoorbeeld de posities van sterren in de astronomie of structuurformules van stoffen in de chemie. Veel aandacht wordt hierbij besteed aan de verbetering van de technieken en instrumenten waarmee die feiten worden verzameld. In de tweede plaats doen 
onderzoekers pogingen om de theorie en "de natuur" beter op elkaar af te stemmen, door theoretische voorspellingen te ontwikkelen die te onderzoeken zijn. Daarvoor moet dle natuur dusdanig geprepareerd worden dat die past in de conceptuele doos van de theorie. In de derde plaats wordt de geaccepteerde theoric zowel theoretisch als experimenteel verder gearticuleerd. Deze activiteit is puzzeloplossen in de hier gebezigde betekenis en bestaat uit het toepassen van een theorie op nieuwe domeinen. In deze paragraaf zall ik mij voornamelijk concentreren op de rol die samples en regels spelen bij het oplossen van puzzels.

In The Siructure of Scientific Revolutions heeft Kuhn benadrukt dat onderzoekers puzzels leren oplossen aan de hand van 'exemplars'. Kuhns bekende voorbeeld is de toepassing van de tweede bewegingswet $f=m a$ op bijwoorbeeld de vrije val, waarbij het basisschema van deze wet wordt getransformeerd in $\mathrm{mg}=\mathrm{m}\left(\mathrm{d}^{2} \mathrm{~s} / \mathrm{dt}^{2}\right) .{ }^{29} \mathrm{In}$ dit voorbeeld blijft de rol van samples en regels echter onderbelicht omdat in dit voorbeeld de nadruk ligt op de mathematische transformaties die het basisschema van de tweede wet ondergaat. De 'koppeling' tussen de theoretische articulatie en het gebruik en prepareren van samples komt in dit voorbeeld niet aan de orde. Zeker in de levenswetenschappen, waar mathematisch gearticuleerde theorieën schaars zijn, staat het afstemmingsprobleem tussen theorie en samples (en regels) centraal in het onderwijs en onderzoek. Puzzeloplossen is in deze takken van de wetenschap nauw verbonden met het 'prepareren" van samples. Het succesvol kunnen toepassen en articuleren van een theorie op een nieuw domein hangt hier af van het gebruik van samples en regels. Darwins evolutietheorie bijwoorbeeld vereist dat onderzoekers op het niveau van de samples en regels de structuur en functie van gebeurtenissen of processen kunnen onderscheiden. In de negentiende eeuwse biologie en paleontologie onderzocht men de vorm van organismen en fossielen met morfologische en taxonomische technieken om vervolgens een reconstructie te kunnen geven van het evolutieproces. Samples van levende soorten en fossielen speelden bij dit onderzoek een cruciale rol omdat daarvan de vorm werd onderzocht. In de loop van de twintigste eeuw is dit type onderzoek ook toegepast op andere organisatie-niveaus, zoals moleculen. Vergelijkingen van de aminozuursequenties van zuivere samples van hormonen bij verschillende soorten worden verricht om inzicht te krijgen in de genetische regulering en evolutionaire ontwikkeling van de aminozuursequenties. Binnen de geologie gebruikt men samples van de oude ijslagen in de poolgebieden om de luchtbelletjes te tellen en te analyseren om inzicht te krijgen in de evolutionaire veranderingen in de $\mathrm{CO} 2$-concentraties in de atmosfeer. Bij de bepaling van de ouderdom en veranderingen van de verschillende lagen van de 
aardkorst gebruikt men tegenwoordig niet alleen paleontologische gegevens, maar onderzoekt men samples van de lagen ook op de aanwezigheid van radioactieve en andere chemische stoffen.

Het toepassen van een theorie op een nieuw domein hangt in de levenswetenschappen eveneens nauw samen met het prepareren wain samples. Aan de hand van een studie van Timbergen c.s. zal in detail worden nagegaan welke rol samples en regels vervullen bij het oplossen van puzzels.

Kokmeeuwen ontdoen zich, nadat het kuiken uit het ei is gekomen, van de lege eischaal. Waarom verwijderen zij de lege eischaal uit het nest? Volgens Tinbergen c.s. dient het verwijderen van de eischaal ertoe om de camouflage van het broed te handhaven. De eischaal is namelijk wit aan de binnenkant hetgeen een opvallende kleur is in de omgeving van het nest. Voor predatoren zou de lege eischaal een handig baken kunnen zijn waarmee zij de kuikens (of de resterende eieren) gemakkelijker zouden kunnen vinden. Tinbergen c.s. hebben deze hypothese in 22 experimenten getest. ${ }^{30}$ In het eerste experiment gebruikten Tinbergen c.s. kippeëieren: de helft daarvan werd mat wit geschilderd en de andere helft werd (ruwweg) kunstmatig gecamoufleerd door ze als meeuweëieren te schilderen. Tinbergen c.s. vroegen zich af of de witte eieren door predatoren (zwarte kraaien) gemakkelijker werden gevonden. De eieren werden daartoe één tegelijk en wijd uit elkaar (tussenruimte 18 meter) in een vallei gelegd buiten de meeuwekolonie. Vervolgens werd geregistreerd welke eieren door predatoren werden weggenomen. Predatoren bleken de mat wit geschilderde eieren en kunstmatig gecamoufleerde eieren even gemakkelijk te vinden: er werd geen significant verschil gemeten. Een weerlegging van de hypothese? Tinbergen c.s. concludeerden dat zij het gezichtsvermogen van de zwarte kraai hadden onderschat. Daarom gebruikten zij voor de herhaling van dit experiment echte kokmeeuweëieren en kokmeeuweëieren die mat wit waren geschilderd. Dit keer werd er wel een significant verschil gevonden: de mat wit geschilderde eieren werden veel gemakkelijker gevonden.

De overige twintig experimenten verschilden qua opzet niet wezenlijk van de hier besproken experimenten. Getest werd onder andere of predatoren eieren met in hun nabijheid een lege eischaal gemakkelijker konden vinden, hoe kokmeeuwen reageerden op verschillend gekleurde voorwerpen in het nest, etcetera. De algemene conclusie die Tinbergen c.s. uit hun onderzoek trokken was dat het verwijderen van de eischaal het broed helpt beschermen tegen predatie.

Allereerst kan er nog eens op worden gewezen dat hier geen sprake is van een Popperiaanse testprocedure. De hypothese die Tinbergen c.s. 
formuleerden was niet afgeleid uit een nieuwe theorie. Achtergrondkennis, in dit geval de evolutietheorie, werd in verband gebracht met een specifiek probleem: waarom werwijderen kokmeeuwen de lege eischaal wit het nest? De achtergrondkennis gebruikten zij om dit probleem in termen van de evolutietheorie te herformuleren zodat een hypothese kon worden opgesteld: 'het verwijderen van de eischaal helpt het broed beschermen tegen predatie'. Deze hypothese werd door hen getest, maar omdat niet de achtergrondkennis werd getest maar een door de onderzoeker geformuleerde hypothese, kon het falen van de test niet aan die achtergrondkennis worden toegeschreven. Tinbergen c.s. hadden het gezichtsvermogen van de zware kraai onderschat en dat was geen verborgen theoretische veronderstelling waaraan het mislukken van de test kon worden toegeschreven, maar een fout van de onderzoekers. Zij hadden de kokmeeuweëieren slecht gecopieerd. De kunstmatig gecamoufleerde eieren bleken bij nader inzien teveel te verschillen van echte kokmeeuweëieren: (1) de grondkleur verschilde, (2) de donkergrijze stippen die op de eieren waren aangebracht waren uniformer van vorm en verdeling dan die op de echte eieren, (3) in tegenstelling tot de natuurlijke stippen hadden ze allemaal dezelfcle kleur, en (4) de gebruikte kippeëieren waren aanzienlijk groter dan de kokmeeuweëieren.

Deze veldexperimenten van Tinbergen c.s. illustreren opnieuw dat puzzeloplossen niet gericht is op het testen van theorieën in de zin waarin Popper daarover schrijft. Omdat de hypothese door onderzoekers wordt geformuleerd, wordt hun persoonlijk vermoeden getoetst. Mislukt een test, dan falen de onderzoekers. Met behulp van Wittgensteins ideeën kan deze stelling van Kuhn verder worden gepreciseerd. De fout die Tinbergen c.s. hadden gemaakt had geen theoretisch karakter, maar was te relateren aan het gebruik van samples en regels. De onderzockers faalden tijdens het eerste experiment omdat zij de sample (het kokmeeuweëi) slecht hadden gecopieerd. Deze conclusie trokken zij op grond van het gedrag van de zwarte kraai.

'Het verbaasde ons te zien hoe gemakkelijk vooral de zwarte kraaien zelfs onze "gecamoufleerde" eieren vonden.(...). Ze kwamen op een hoogte van $6 \mathrm{~m}$, omlaag kijkend, aanvliegen. Het plotseling minderen van snelheid en het daarna neerstrijken in de buurt van een ei waren de onmiskenbare tekenen dat ze het ei hadden gezien. ${ }^{31}$

In deze beschrijving wordt een grammaticale regel voorondersteld, namelijk een regel voor het gebruik van het begrip 'waarnemen'. Volgens Wittgenstein behoort het tot de grammatica van dit begrip dat wij 
op grond van het gedrag van dieren en mensen in meer of mindere complexere situaties besluiten of zij iets kunnen waarnemen. Of dieren kannen waamemen bepalen we door hun gedrag te observeren. ${ }^{32}$ Deze grammaticale regel wooronderstelden Tinbergen c.s. in hun onderzoek bij hun beschrijvingen: op basis van het gedrag van de zwarte kraai concludeerden zij dat zij 'het gezichtswermogen van zwarte kraai hadden onderschat' en dus dat zij de sample slecht hadden gecopieerd.

\section{5}

\section{Samples, methodologische stijlen en theorieën}

Aan de hand van het onderzoek van Tinbergen c.s. is geillustreerd welke rol samples en regels vervullen bij het oplossen van puzzels. Fouten die onderzoekers maken kunnen worden gerelateerd aan het gebruik van samples en regels in de lokale onderzoekssituatie. De wijze waarop samples en regels functioneren in het onderzoek verschilt tussen disciplines en daarom kunnen we verwachten dat ook de manier waarop puzzels of problemen worden opgelost zal verschillen tussen disciplines. Er zullen bepaalde affiniteiten bestaan tussen het gebruik van samples, technieken, methodologische stijlen en theorieën. Deze verschillen en affiniteiten zullen vooral 'zichtbaar' worden in de grensgebieden tussen disciplines. Chemici bijvoorbeeld werken met samples van zuivere stoffen die zij experimenteel verder onderzoeken. Daarom zullen zij levenswetenschappelijke problemen eerder op moleculair niveau onderzoeken en daarbij gebruiken maken van theorieën over structuur van moleculen. Biologen daarentegen werken met levende organismen en zullen eerder de functic van bepaalde reacties onderzoeken. Afhankelijk van de probleemsituatie kunnen daardoor specifieke onderzoeksen argumentatie-strategieën worden verwacht ten aanzien van het aanleg-omgeving vraagstuk. Aan de hand van een voorbeeld uit de immunologie kan dit nader worden uitgewerkt.

De specificiteit van de binding tussen antilichamen en antigenen is voortdurend het onderwerp geweest van controversen tussen chemici en biologen. Voor chemici was de specificiteit een empirisch-chemisch probleem dat uiteindelijk in termen van chemische theorieën over de structuur van moleculen kon worden opgelost. Na Landsteiners haptenen-onderzoek probeerde men de binding tussen antilichamen en antigenen experimenteel te onderzoeken door variaties aan te brengen in de structuur van haptenen. Landsteiner had laten zien dat organismen antilichamen kunnen vormen tegen de meest uiteenlopende synthetisch geproduceerde chemische stoffen die gekoppeld waren aan drager-ei- 
witten ('haptenen"). Hierdoor kon men het probleem van de immunologische specificiteit empirisch-chemisch onderzoeken en zich richten op de affiniteit van de antilichaam-antigeen-interacties. Nadat Marrack begin jaren dertig de equilibrium dialyse-techniek operationeel had gemaakt voor de antilichaam-antigeen reactie, kon men de precipitatiereactie kwantitatief in een in vitro-situatie bestuderen. In principe werd het nu mogelijk om met deze techniek de precipitatie-reacties kwantitatief te bepalen zodat de affiniteit van antigenen en antilichamen verder kon worden onderzocht. Problematisch was echter dat antilichamen nooit in een homogene, zuivere vorm woorkomen. De equilibrium dialyse-techniek is immers toegesneden op zuivere stoffen die kunnen interacteren. In de jaren dertig beargumenteerde Heidelberger dat de antilichaam-antigeen-reactie chemisch kon worden verklaard met behulp van de wet van de massawerking wanneer die reactie werd geduid in moleculaire termen. ${ }^{33}$ De vorming van het precipitaat was volgens. hem het resultaat van een reeks bimoleculaire reacties. Schematisch kan dit als volgt worden weergegeven:

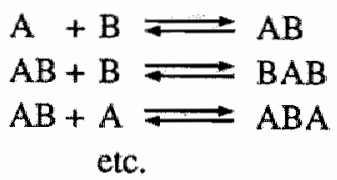

Deze interpretatie van de precipitatie-reactie werd in 1940 door Pauling uitgewerkt. ${ }^{34}$ Pauling ontwikkelde een algemene instructietheorie ter verklaring van de immunologische speciliciteit in een structuralistische terminologie. Volgens Pauling verliep de antilichaamvorming in twee stappen. Eerst werd volgens hem de polypeptideketen gevormd waarna het molecuul werd opgevouwen tot een driedimensionaall molecuul. Tijdens het opvouwen fungeerde het antigeen als mal zo dat het antilichaam een vorm $\mathrm{kreeg}$ complementair aan de determinante groep van het antigeen.

Deze instructietheoretische verklaring van de specificiteit van de antilichaam-antigeen interactie werkte Pauling uit voor de precipitatiereactie. Hij veronderstelde - conform de ideeën van Heidelberger - dat de antilichamen twee bindingsplaatsen bezaten en ontwikkelde voorspellingen voor het verloop van de precipitatie-reactie. Deze voorspellingen werden vervolgens door Pauling en zijn medewerkers in experimenten getest. De uitkomst van de experimenten stemde echter niet overeen met de voorspellingen. Pauling c.s. vonden bijvoorbeeld dat de hoeveelheid gevormd precipitaat niet recht evenredig toenam met de hoeveelheid toegevoegd hapteen. Deze afwijking werd door hen toege- 
schreven aan de: 'heterogeneity of the antiserum, which appears to contain antibodies of greatly different combining powers". ${ }^{35}$ Dit probleem werd door Pauling c.s. opgelost door de data te corrigeren met behulp van de 'Gaussian error function'. Omdat bij het opvouwen van de polypeptideketens uiteenlopende krachten in het geding waren, zouden volgens Pauling c.s. de verschillende antilichamen tegen Eén type antigeen zelden identiek zijn waardoor de bindingskracht rond een statistisch gemiddelde fluctueerde. Deze conclusie genereerde natuurlijk op haar beurt weer nieuwe vragen. Welke krachten zorgden voor de variaties in de antilichamen? Hoe groot was de bindingsplaats? In hun vervolgonderzoek probeerden Pauling c.s. dit soort puzzels nader te onderzoeken.

Onderwijl hadden biologisch georienteerde onderzoekers, zoals Burnet en Jerne, gewezen op een aantal beperkingen van de chemische aanpak én van de instructietheorie. ${ }^{36}$ Hun belangrijkste kritiek was dat chemici de biologische aspecten van de immunologische reactie totaal negeerden. De immunologische reactie had een duidelijke overlevingswaarde voor het organisme en dit aspect moest volgens Burnet en Jerne worden verklaard. Zo was al geruime tijd bekend dat het eerste contact met een virus of een bacterie kon leiden tot ziekte of dood, terwijl bij het tweede contact organismen gezond bleven. Bij het tweede contact met een antigeen werden namelijk veel meer antilichamen geproduceerd dan bij het eerste en dit kon volgens Burnet en Jerne niet met de instructietheorie worden verklaard. Chemici hadden met andere woorden geen oog gehad voor het centrale kenmerk van de immunologische response: het ontstaan van immuniteit.

Jerne begon zijn immunologisch onderzoek met een studie naar de aviditeit van de antilichaam-antigeen-binding. Naast de fysische en chemische analyses ${ }^{37}$ van de antilichaam-antigeen-interacties, die zich vooral concentreerden op de affiniteit wan deze interacties, hadden al geruime tijd biologisch georiënteerde onderzoekers gewezen op de 'aviditeit' van deze interacties: een kwalitatieve, 'vitale' kracht die naast de chemische (en fysische) krachten kon worden onderscheiden. Wat men daar echter precies onder moest verstaan was echter lang niet altijd duidelijk. De term verwees naar het biologisch karakter van de antilichaam-antigeen-interacties en was geïntroduceerd om problemen rond Ehrlichs standaardisering van antisera voor klinisch gebruik te ondervangen. ${ }^{38}$ Ehrlich veronderstelde een eenvoudig lineair verband tussen de hoeveelheid antitoxine die nodig was om een bepaalde hoeveelheid toxine te neutraliseren. Dit lineaire verband was echter van meet af aan omstreden en werd tijdens in vivo experimenten zelden gevonden. Deze gevonden afwijkingen konden volgens biologisch georienteerde onder- 
zoekers niet worden verklaard in termen van chemische affiniteit. In zijn dissertatie $A$ study of avidity ${ }^{39}$ pikte Jerne deze problemen op en ontwikkelde op basis wan de zogenaamde 'Marrack-Heidelberg-Pauling' interpretatie van de antilichaam-antigeen interactie een wiskundige formule waarmee hij de 'aviditeits-constante' kon berekenen. Hiermee maakte Jerne duidelijk dat het om een biologisch fenomeen ging; niet om een chemische kwestie. Uit zijn experimenteel onderzoek bleek onder andere dat deze constante hoger was bij dieren die meer dan énn keer waren geimmuniseerd dan bij dieren die één keer geimmuniseerd waren.

Vier jaar na zijn dissertatie ontwikkelde Jerne deductief een aanlegtheorie die deze toename van de specificiteit van de antilichaam-antigeen-binding met een selectiemechanisme verklaarde. ${ }^{40} \mathrm{Hij}$ postuleerde dat organismen door een genetisch gereguleerd mechanisme een groot aantal verschillende antilichamen produceren die werden gegeneerd door een random proces. Deze antilichamen werden met andere woorden continu geproduceerd, onafhankelijk van het antigeen, in een grote variëteit van verschillende configuraties. De toename van aviditeits-constante verklaarde Jerne uit het feit dat er selectie plaatsvond nadat een antigeen een organisme was binnengedrongen. $\mathrm{Na}$ het eerste contact met antigeen zou het organisme meer antilichamen gaan produceren die 'passen bij' het antigeen waardoor de aviditeits-constante na verloop van tijd toenam (vergelijk ook hoofdstuk 6).

Het verschil tussen de chemische en biologische benadering van de immunologische specificiteit resulteerde uiteindelijk in twee tegengestelde theorieën: de instructietheorie versus de selectietheorie. Dit verschil was verbonden met het gebruik van samples en experimentele technieken. Voor chemici was de specificiteit van de antilichaam-antigeen binding te herleiden tot de affiniteit van die binding die met samples van zuivere stoffen in een in vitro-situatie kon worden onderzocht. Men verwachtte dat de aviditeit uiteindelijk in termen van chemische affiniteit konden worden geïnterpreteerd. De biologen onderzochten de specificiteit in een in wivo-situatie en benadrukten de functie van de antilichaam-antigeen-binding voor de immuniteit van het gehele organisme. Biologisch gezien is het immers functioneel dat die binding in de Joop van de immunisatie steeds beter wordt. Voor biologen was de aviditeit van de antilichaam-antigeen-interacties méér dan een louter chemische binding. Schematisch kan de tegenstelling tussen de chemische en de biologische benadering met de volgende begrippenparen worden weergegeven: 


\section{Chemie}

Structuur

Kwantitatief

Zuivere stoffen

In vitro

Equilibrium dialyse

Affiniteit

Reductionistisch

Mechanicistisch

Instructietheorie
Biologie

Funktie

Kwalitatief

Cellen, etc.

In vivo

Vaccinatie

Aviditeit

Holistisch

Vitalistisch, organicistisch

Selectietheorie

Uit deze tegenstelling tussen de chemische en biologische benadering volgden specifieke argumentatie-strategieën die zowel een inhoudelijk als een methodologisch karakter hadden. Deze inhoudelijke en methodologische tegenstelling kan allereerst met Poppers tegenstelling tussen de Zoeklichttheorie (de selectietheorie gekoppeld aan de deductieve stijl) en de Emmertheorie (de instructietheorie gekoppeld aan de inductieve stijl) worden geinterpreteerd. Zoals op grond van Poppers tegenstelling kon worden verwacht, betekende de variabiliteit van de antilichaam-antilichaam-bindling voor chemici dat er 'fouten' waren gemaakt bij het opvouwen van de polypeptideketens (net zoals fouten in de kennis volgens de Emmertheorie te wijten zijn aan onzorgvuldige verwerking van zuivere ervaring). Voor biologen betekende deze variabiliteit niet dat er 'fouten' waren gemaakt bij het opwouwen, maar was juist een reden om de specificiteit theoretisch in termen van een variatieen selectiemechanisme deductief te verklaren.

Deze Popperiaanse interpretatie lijkt adequaat voor een verk]aring van de inhoudelijke en methodologische tegenstelling tussen de chemische en biologische benadering. Toch wordt met deze interpretatie een aantal cruciale aspecten niet in beeld gebracht. De discussies rond de specificiteit van de immunologische response laten zien dat er méer op het spel stond dan louter theoretische en methodologische kwesties. De theoretische en methodologische tegenstelling was verbonden met het gebruik van samples. Er bestonden specifieke werbanden tussen het gebruik van samples, technieken, methodologische stijlen en theorieën. De instructietheorie was het product wan een inductieve, structuralistische benadering waarin het gebruik van zuivere samples van stoffen centraal stond, terwijl de selectietheorie het product was van deductief, functionalistisch onderzoek waarin de nadruk lag op cellen, organismen, etcetera. Juist deze koppelingen 'predisponeerde' chemici en 
biologisch georienteerde onderzoekers tot specifieke onderzoeks-, argumentatie- en handelingsstrategieën.

Deze precisering van de Popperiaanse interpretatie geeft tevens een eerste aanzet tot een kritiek op die interpretatie. Aanleg en omgeving stonden - in termen van Poppers tegenstelling - zowel inhoudelijk als methodologisch tegenover elkaar. Toch zijn chemici en biologen uiteindelijk tot samenwerkingsverbanden gekomen, waarbij de instructietheorie van het toneel is verdwenen. Was dit een inhoudelijke én methodologische omwenteling, waarbij de biologen 'gelijk' en de chemici 'ongelijk" kregen? Voor een antwoord op deze vraag moeten we nagaan hoe deze overgang werd bewerkstelligd. Deze overgang kwam tot stand doordat de globale theoretische omslag gepaard ging met het ontstaan van lokale samenwerkingsverbanden op methodologisch vlak. In de eerste plaats werd op theoretisch niveau de selectietheorie op moleculair vlak verder gearticuleerd waardoor de resultaten van het chemisch onderzoek in termen van die theorie konden worden geïnterpreteerd (zie hiervoor hoofdstuk 6). Deze theoretische articulatie was echter niet primair de reden waardoor chemici de klonale selectietheorie accepteerden en de instructietheorie verwierpen. Die omslag kwam veeleer voort uit veranderingen op het niveau van de samples waardoor de mogelijkheden voor experimenteel chemisch onderzoek radikaal veranderden. Ontwikkelingen binnen de biologische, deductieve stij] resulteerden in de tweede plaats in het creëren wan samples die bruikbaar waren in het chemisch onderzoek. Een voorspelling van de selectie theorie: én cel produceert én type antilichaam, werd later, door cellen te 'prepareren', 'omgebouwd' tot een regel en mondde uit in de experimentele produktie van monoklonale antilichamen, dat wil zeggen zuivere samples van (willekeurig welk type) antilichaam. Van deze monoklonale antilichamen konden chemici vervolgens de aminozuursequentie bepalen. 'Sequencing', een al gangbare biochemische techniek, en later de DNA-recombinant techniek, werden toen met andere woorden toepasbaar binnen de immunologie. De resultaten van dit chemisch onderzoek hadden uiteindelijk een verdieping van de selectietheorie op moleculair vlak tot gevolg.

De inhoudelijke en methodologische tegenstelling tussen chemici en biologisch georiënteerde onderzoekers werd dus op het niveau van de samples opgelost. Door een theoretische voorspelling van de selectie theorie te 'vertalen' in een methodologisch probleem ontstond een regelgeleide praktijk rondom nieuwe, gecreëerde samples. In deze praktijk konden chemici en biologen samenwerken. Naast de globale theoretische omslag resulteerden de ontwikkelingen in de deductieve stijl, in interactie met de chemische inductieve stijl, in een nieuwe 
methodologische praktijk. De theoretische discussie tussen instructietheoretici en klonale selectietheoretici, waarin de globale juistheid van ideeën op het spel stond, werd uiteindelijk getransformeerd in een regelgeleide praktijk waarin onderzoekers (voorlopig) alleen lokaal fouten konden maken bij het gebruik van - nieuwe - samples en regels. Door deze transformaties in de lokale onderzoekspraktijk zouden chemici uiteindelijk de biologische selectie theorie accepteren én verfijnen.

Uit deze beschrijving van ontwikkelingen binnen de immunologie kunnen we concluderen dat ook de tegenstelling tussen de deductieve en de inductieve stijl op lokaal niveau niet hoeft te bestaan. De deductieve stijl kan leiden tot nieuwe, gecreëerde samples waardoor er afhankelijkheidsrelaties ontstaan tussen de twee methodologische stijlen. Samples kunnen kortom niet alleen de bindende elementen worden tussen de inhoudelijke aanleg- en omgevingstheorieën, zoals dat het geval was in de gedragsembryologie, maar ook tussen de methodologische posities waardoor de tegenstelling lokaal kan worden opgeheven.

\section{7 \\ Conclusies}

Hoewel op Poppers wetenschapsfilosofie epistemologisch weinig valt af te dingen, heeft zijn filosofie in methodologisch opzicht een aantal beperkingen. Ten eerste kunnen met Poppers wetenschapstheorie slechts ontwikkelingen in de traditie van de deductieve stijl worden gereconstrueerd. Naast een deductieve stijl kunnen we echter in de wetenschappelijke praktijk een inductieve stijl onderscheiden die kan worden gekarakteriseerd in termen van (Kuhniaans) puzzeloplossen. Ten tweede kunnen we verwachten dat, naast discussies rondom basisuitspraken, andere, niet-theoretische uitspraken centraal staan in het wetenschappelijk onderzoek. Wittgensteins filosofie, met name zijn latere ideeën over het functioneren van samples en regels, kan op dit punt worden gebruikt om empirisch onderzoek nader te karakteriseren.

De tegenstelling tussen de deductieve stijl en de inductieve stijl, die Popper heeft geïnterpreteerd in termen van Zoeklichttheorie en de Emmertheorie, moet dus op een andere manier worden verklaard. De nieuwe interpretatie kan op een aantal niveaus worden uitgewerkt (vergelijk hoofdstuk 2, par 2.3). Op epistemologisch niveau is Poppers wetenschapstheorie hier niet bekritiseerd, omdat epistemologisch niet aan het theoretisch karakter van uitspraken valt te tornen. Omgekeerd is de inductieve stijl hier niet gerechtvaardigd met behulp van de inductieve filosofie. Twee centrale kenmerken van deze filosofie, name- 
lijk de gedachte dat kennis te funderen is in ervaring en het inductie-beginsel, zijn niet gebruikt om de inductieve stijl te rechtvaardigen. $\mathrm{Zij}$ spelen in de inductieve stijl ook geen essentielle rol. Puzzeloplossen, het centrale methodologische element in de inductieve stijl, neemt de plaats over van inductief generaliseren. Tegenover deductief problemen oplossen staat kortom niet meer inductief generaliseren, maar puzzeloplossen. Tijdens probleemoplossen worden nieuwe theorieën naar aanleiding van problemen verzonnen die vervolgens op hun toetsbare consequenties worden onderzocht. Puzzeloplossen bestaat uit het construeren van hypothesen door empirische problemen in termen wan een geaccepteerde theorie te herformuleren. Die hypothesen worden vervolgens wel getest, maar deze testprocedure heeft een ander karakter dan het deductief testen van theorieën. Omdat de hypothesen tijdens puzzeloplossen niet logisch worden afgeleid uit de geaccepteerde theorie, staat die theorie tijdens een test niet ter discussie. Daarom fungeert de geaccepteerde theorie tijdens puzzeloplossen niet als een zoeklicht, maar eerder als een fonds.

Omdat puzzeloplossen niet te rechtvaardigen is met behulp van het filosofisch inductivisme, komen ook de oudere inductieve methodologische idealen in een ander daglicht te staan. Inductieve idealen, zoals het belang van precisie en de nadruk op de complexiteit van de wereld, kunnen nu rechtstreeks worden gekoppeld aan de handelingspraktijken rondom samples en regels. Ook hier geldt dus dat deze idealen niet kunnen worden gerechtvaardigd onder verwijzing naar de traditionele inductieve filosofie. $\mathrm{Zij}$ komen voort uit het feit dat onderzoekers zorgvuldigheid in acht moeten nemen bij het prepareren van samples, bij het beschrijven van 'de natuur" met behulp van representatiemethoden, etcetera.

Dat ten slotte de hier ontwikkelde notie 'inductieve stijl' gebruikt kan worden voor een historisch-sociologisch adequatere wetenschapstheorie over het feitelijk methodologisch handelen is geillustreerd in dit hoofdstuk. Een beschrijving van het feitelijk handelen in termen van de inductieve stijl kan aan de hand van vier elementen worden gegeven: puzzeloplossen, fonds, samples en regels. Aangezien vooral de functie van samples en regels varieert per vakgebied, kunnen deze noties worden gebruikt om verschillen tussen de natuur-, levens- en sociale wetenschappen nader te analyseren. In de volgende hoofdstukken zullen een aantal verschillen aan de orde komen.

De transformaties van het aanleg-omgeving vraagstuk in de wetenschapstheorie heeft in ieder geval twee interessante consequenties. In de eerste plaats kunnen onderzoekers relatief eenvoudig tot overeenstemming komen over concrete onderzoeksresultaten, omdat samples 
en regels centraal staan in de lokale onderzoekspraktijk. Ondat het gebruik van samples en regels in methodologisch opzicht theorie-neutraal is, kunnen inhoudelijke geschillen rondom het aanleg-omgeving vraagstuk in de levenswetenschappen op het niveau van de samples en regels worden beslecht. Het concrete, empirisch onderzoek, waarin samples en regels niet ter discussie hoeven te staan, dwingt onderzoekers als het ware om met elkaar te communiceren. Dit verklaart waarom debatten over ideeën vaak beslecht worden wanneer die debatten te relateren zijn aan concreet empirisch onderzoek. Pas wanneer ideeën 'zichtbaar' zijn te maken aan de hand van samples en regels winnen zij aan overtuigingskracht. Dat is de les die we kunnen trekken uit de ontwikkelingen in de embryologie van gedrag en de immunologie. Ideeën, die nog niet vertaald zijn in een empirische praktijk, dienen eerst methodologisch gekoppeld te worden aan samples en regels willen zij hun speculatief karakter verliezen en algemeen geacceptecrd worden.

In de tweede plaats kan met samples en regels inzichtelijk worden gemaakt hoe de methodologische tegenstelling tussen de deductieve en de inductieve stijl kan worden opgeheven. Het voorbeeld van de immunologie liet zien dat via de deductieve stijl een nieuwe chemische onderzoekspraktijk rondom monoklonale antilichamen werd gecreëerd. De acceptatie van een inhoudelijke aanlegtheorie werd bewerkstelligd door via de deductieve stijl samples te creëren. Hoe dat precies gebeurde, zal in hoofdstuk 6 nader worden geanalyseerd.

De affiniteiten tussen inhoudelijke en methodologische posities zijn aanzienlijk complexer dan op grond van Poppers ideeën kon worden verwacht. In de hoofdstukken 5,6 en 7 wordt deze toename in complexiteit verder onderzocht door verschillen tussen de natuur-, levens-, en gedragswetenschappen aan de hand van de tegenstelling tussen de deductieve en inductieve stijl én de noties samples en regels nader te problematiseren. In al deze wetenschapsgebieden is het aanleg-omgeving vraagstuk de aanleiding geweest voor controversen, maar steeds op verschillende manieren. Deze verschillen staan in de aankomende hoofdstukken centraal. Inhoudelijke en methodologische veranderingen in het aanleg-omgeving vraagstuk zullen expliciet aan de hand van de noties samples en regels worden geanalyseerd. In het volgende hoofdstuk zal een recente controverse in de levenswetenschappen worden geanalyseerd: die tussen de deductivistische sociobiologie en de inductivistische ethologie. 


\section{5}

\section{Sociobiologie \\ De wiskundige benadering van gedrag}

\section{1 \\ Inleiding}

In het midden van de jaren zeventig laaiden de discussies rond het aanleg-omgeving vraagstuk weer als vanouds op naar aanleiding van een nieuwe onderzoekstraditie. Deze onderzoekstraditie kwam in de loop van de jaren zestig en begin jaren zeventig tot bloei en werd in 1975 door de entomoloog Wilson gedoopt tot 'sociobiologie'. 'Vanaf haar geboorte is de sociobiologie het onderwerp geweest van felle debatten. In exoterische kringen botsten sociobiologische verklaringen van het menselijk gedrag met sociaalwetenschappelijke verklaringen. In esoterische kringen werd de sociobiologische onderzoekstraditie door sommigen gezien als een nieuwe vorm van 'genetisch determinisme'. Hierbij doelde men op de eenvoudige correspondentie tussen genen en gedrag waarvan sociobiologen leken uit te gaan. Een gen voor altruisme, een gen voor homosexualiteit; naïever kon het volgens sommige kritici niet. Wanneer de ontwikkelingsbioloog Bateson in 1982 terugblikt, constateert hij dat de eenvoudige correspondentic tussen genen en gedrag 'made a lot of people very angry and for some years a useful dialogue between sociobiologists and developmentalists seemed impossible'. Gezien de eerdere controversen over het aanleg-omgeving vraagstuk hoeft dit niet meer onze verbazing te wekken (zie hoofdstuk 3 ). Wie uitgaat van een eenvoudige correspondentie tussen genen en gedrag suggereert dat gedragselementen genetisch zijn bepaald en die suggestie is volgens Bateson onhoudbaar. In de ontwikkeling van gedrag spelen volgens hem zowel genetische factoren als omgevingsfactoren een rol. Ter staving van deze gedachte verwijst Bateson expliciet naar het onderzoek van Gottlieb. 
Hoewel sociobiologen vaak spreken over 'aangeboren gedrag' of 'een gen voor een bepaald gedragselement', is het onjuist om hieruit af te leiden dat zij daadwerkelijk een vorm van genetisch determinisme verdedigen. Verderop in zijn artikel merkt Bateson op dat sociobiologen wel terdege onderkennen dat omgevingsfactoren een rol kunnen spelen in de ontwikkeling van gedrag. Zij kunnen daar echter in hun onderzoek geen aandacht aan besteden, omdat sociobiologen genetisch-evolutionaire verklaringen ontwikkelen. Bateson: 'evolutionary theories that consider the costs and benefits of possessing a gene which exerts a specific influence in a particular context, must necessarily be silent on how the developmental process works". ${ }^{3}$ Omdat genetischevolutionaire theorieèn over gedrag betrekking hebben op de competitie tussen gedragskenmerken (of de genen die daaraan ten grondslag liggen), kunnen die theorieèn niets zeggen over de wijze waarop die kenmerken in de ontogenie tot stand komen. Dit verschil tussen evolutionaire en ontogenetische verklaringen, of tussen 'ultimate' oorzaken en 'proximate' oorzaken, verklaart volgens Bateson waarom het sociobiologisch taalgebruik een vorm van 'genetisch determinisme' suggereert, hoewel sociobiologen geen genetisch deterministen hoeven te zijn.

In dit hoofdstuk zal ik het aanleg-omgeving vraagstuk nader onderzoeken aan de hand van de sociobiologische onderzoekstraditie. Daarvoor wordt eerst ingegaan op het onderscheid tussen 'proximate' en 'ultimate' oorzaken en de consequenties van dit onderscheid voor het aanleg-omgeving vraagstuk (par. 5.2 en 5.3). Ik zal betogen dat sociobiologen genetisch-evolutionaire verklaringen geven voor sociaal gedrag en daarbij gebruik maken van een deductieve onderzoeksstijl. De koppeling tussen de deductieve benadering en het zoeken naar 'ultimate' oorzaken leidt tot een gencentrische theorie. Vervolgens worden de consequenties van deze benadering uitgewerkt aan de hand van een controverse tussen ethologen en sociobiologen over de functie van 'displays' (par. 5.4). In deze controverse botsten de inductieve benadering van de ethologen en de deductieve benadering van de sociobiologen. Ethologen hadden op grond van zorgvuldige beschrijvingen en observaties de hypothese ontwikkeld dat dieren in conflicten informatie uitwisselen over bedoelingen. Sociobiologen daarentegen concludeerden op basis van theoretisch onderzoek dat informatie-overdracht over bedoelingen geen evolutionair stabiele strategie kan zijn. Zij betwijfelden de waarde van het ethologisch onderzoek, aangezien hun modellen voorspelden dat de bedoelingen van tegenstanders in conflicten altijd verhuld moesten blijven. Deze controverse zal ik in dit hoofdstuk analyseren en de resultaten van de analyse gebruiken om de wetenschaps- 
theoretische ideeen over de relatie tussen theorie en ervaring verder te verfijnen. Hierbij zal gebruik worden gemaakt van een aantal ideeën van Lakatos en zijn leerlingen over de rol van heuristicken bij de ontwikkeling van theorieën. Met de notic 'heuristiek' hebben Lakatos c.s. een nadere invulling gegeven van de verschillende manieren waarop een theorie (of een onderzoekprogramma) kan worden uitgebouwd. Daarbij wordt een onderscheid gemaakt tussen twee heuristieken die als extremen op een continuüm kunnen worden geplaatst. ${ }^{4}$ Bij wiskundige heuristieken wordt de uitbouw van een theorie goeddeels door een interne dynamiek gestuurd omdat voor de verdere articulatie van de theorie gebruik wordt gemaakt van mathematische theorieën. Daar tegenover staat een feit-afhankelijke heuristiek, waarbij de ontwikkeling van een theorie op gang wordt gebracht door de ontdekking van anomalieën of het verzamelen van nieuwe feitten. Deze ideeën over het functioneren van de wiskundige en de feit-afhankelijk heuristieken zal ik in dit hoofdstuk gebruiken om de verschillen tussen de sociobiologische en ethologische onderzoekstraditie nader te onderzoeken.

\section{2 \\ Proximate en ultimate theorieën}

Proximate-causale theorieën proberen een antwoord te geven op de vraag hoe gedragskenmerken tijdens het leven van een individu ontstaan. ${ }^{5}$ Het onderzoek van Gottlieb dat in hoofdstuk 3 is besproken is een voorbeeld van onderzoek gericht op proximate-causale theorieën. Gottlieb toonde aan dat zelfprikkeling een belangrijke factor is bij de ontwikkeling van het discriminatie-vermogen van pekingeenden. Ultimate-causale theorieën proberen een antwoord te geven op de vraag waarom gedragskenmerken zijn ontstaan. Waarom is bijvoorbeeld het specifieke ontwikkelingspatroon bij pekingeenden uitgeselecteerd in de evolutie? Wat is de functie of overlevingswaarde van deze ontwikkelingsstrategie? Dat zijn vragen die niet met embryologische technieken kunnen worden beantwoord en een evolutionair perspectief vereisen. Een ultimate-verklaring voor de ontwikkelingsstrategie van pekingeenden zou kunnen zijn dat het voor pas uitgekomen kuikens belangrijk is om zo snel mogelijk de moeder te herkennen. Door zelfprikkeling zou de band met de moeder sneller tot stand worden gebracht waardoor deze dieren niet worden blootgesteld aan lethale temperatuurschommelingen en bovendien beter beschermd zijn tegen natuurlijke roofvijanden. Deze hypothese kan natuurlijk alleen door evolutionair onderzoek verder worden onderzocht. 
Dat er een essentieel verschil bestaat tussen ultimate-oorzaken en proximate-oorzaken kan worden geillustreerd aan de hand van het onderzoek van Pittendrigh met Drosophila's. ${ }^{6}$ Vooral de pas uit de pop gekropen Drosophila's zijn bijzonder gevoelig voor uitdroging. Ze kunnen in te droge lucht hun vleugels niet strekken waardoor de vleugels verschrompelen. Het ontpoppingsproces bij deze vliegen verloopt echter in de vroege ochtend wanneer de vochtigheidsgraad van de lucht hoog is en zij dus weinig risico lopen. De functie van het ontpoppen in de vroege ochtenduren kan dus worden gezien als een aanpassing die in de evolutie is uitgeselecteerd. Het onderzoek van Pittendrigh liet echter zien dat de vochtigheidstoestand van de lucht geen rol speelt bij de proximate-veroorzaking van de ontpopping. De proximate-veroorzaking bleek de wisseling van donker naar licht te zijn: door die overgang wordt een inwendig klokmechanisme op gang gebracht dat ervoor zorgt dat de vliegjes precies in de vroege ochtend in het laatste stadium van het ontpoppingsproces zijn beland. In dit voorbeeld is er dus sprake van een scheiding tussen de ultimate-veroorzaking en de proximate-veroorzaking.

Proximate-causale theorieën en ultimate-causale theorieën geven dus verschillende verklaringen voor het gedrag. Er hoeft dan ook geen directe samenhang te bestaan tussen deze twee benaderingen. Het ontogenetisch onderzoek kan zich onafhankelijk ontwikkelen van het evolutionair onderzoek. Theoretisch bestaat er natuurlijk wel cen link tussen de fylogenie en de ontogenie. Vroeger werd de link gelegd via de recapitulatietheorie; later heeft met name de Beer ${ }^{7}$ een 'nieuwe' theorie ontwikkeld waarin naast 'acceleratie' 'retardatie' wordt onderscheiden en waarop een aantal auteurs hebben voortgeborduurd. Deze theorieën worden wel samengevat in de slagzin: 'fylogenie is gemodificeerde ontogenie'. Maar deze theoretische link hoeft op zich geen rol te spelen in het ontogenetisch of evolutionair onderzock. Dit kan worden geïllustreerd aan de hand van de teloorgang van Haeckels recapitulatietheorie. $^{8}$

Volgens Haeckel is de ontogenie een versnelde herhaling van de fylogenie. Tijdens de ontogenie makt het individu de evolutie van soort nog eens in versneld tempo door. De centrale principes van de recapitulatietheorie zijn dat (1) elk nieuw ontwikkelingsstadium aan het einde van de al doorlopen stadia werd toegevoegd (een door Lamarcks evolutietheorie geinspireerde gedachte), en dat (2) door 'condensatie' de algehele ontwikkeling werd ingekort. Beide principes zijn onjuist. Ten eerste kunnen in principe nieuwe ontwikkelingsstadia in elke fase van de ontwikkeling worden ingevoegd, en ten tweede komt 'retardlatie' voor naast 'acceleratie". 
Hoewel Haeckel met zijn biogenetische wet een 'link' had gellegd tussen de ontogenie en de fylogenie, lag de nadruk in zijn theorie op de fylogenie. De fylogenie was in zijn ogen de 'mechanische oorzaak' van de ontogenie. Het vergelijkend morfologisch onderzoek naar de ontwikkelingsstadia diende alleen om de fylogenetische ontwikkeling te reconstrueren. De proximate-veroorzaking van de ontwikkelingsprocessen speelde in zijn onderzoek dan ook geen enkele rol.

Deze theorie werd wel door morfologen gekritiseerd, maar deze kritiek had weinig effect. De tegenvoorbeelden werden door Haeckel en andere werdedigers van de recapitulatietheorie aangepast. Belangrijker voor de teloorgang van de recapitulatietheorie was de opkomst van de experimentele embryologie (en later de genetica). De experimenteel embryologen stelden zich echter niet expliciet tot doel kritiek te leveren op de recapitulatietheorie. $\mathrm{Zij}$ onderzochten de ontogenetische ontwikkeling en stonden in zekere zin 'indifferent' tegenover de theorie. In plaats van de beschrijvende, vergelijkende methode, die werd gebruikt voor de beantwoording van fylogenetische vragen, gebruikten embryologen als Driesch, His en Roux een experimentele methode voor de beantwoording van louter ontogenetische vragen. Over het verband tussen de ontogenetische ontwikkeling en de fylogenetische ontwikkeling deden zij geen uitspraken.

De vergelijkende morfologie en de experimentele embryologie ontwikkelden zich vanwege het verschil tussen fylogenetische benadering en de ontogenetische benadering volledig onafhankelijk van elkaar. Pas later zouden de resultaten van het experimenteel embryologisch onderzoek (en de genetica) tot de teloorgang van de recapitulatietheorie van Haeckel leiden. Onderzoek naar de proximate-veroorzaking van de ontwikkeling had dus als onbedoeld effect dat onze kijk op de 'link' tussen de fylogenie en ontogenie uiteindelijk is veranderd. ${ }^{9}$

De conclusie die we uit deze episode uit de geschiedenis van de biologie kunnen trekken is dat, hoewel er een theoretische 'link' is tussen de fylogenie en de ontogenie, ontogenetische studies niet direct consequenties hebben voor fylogenetische vragen (en vice versa). Dit 'uit de pas lopen' van ontogenetische en fylogenetische studies zal ook aan de orde komen bij de bespreking van de verhouding tussen de ethologie en de sociobiologie. De sociobiologische benadering van de ultimate-veroorzaking van gedrag ontwikkelle zich in eerste instantie volledig onafhankelijk van het ethologisch onderzoek. Pas eind jaren zeventig werden de resultaten van het sociobiologisch onderzoek relevant voor de ethologische theorievorming. 


\section{3}

\section{Speltheorie}

De sociobiologie is als vak geleidelijk ontstaan uit een aantal tradities in de biologie: de ethologie, de populatiegenetica en de oecologie. Door probleemverschuivingen die in de loop van de jaren zestig en zeventig hun beslag kregen ontstond een nieuw sociaal en cognitief netwerk. Van centraal belang hierbij waren ideeën die voortvloeiden uit esoterische probleemsituaties. Een van de belangrijkste was MacArthurs optimalisatietheorie, waaruit een nieuw begrip van de aangepastheid van gedrag groeide. ${ }^{10}$ MacArthurs op het eerste gezicht triviale idee was dat het gedrag van dieren in hun oecologische nis de uitkomst was van een historisch evolutieproces waarin maximalisatiestrategieën een centrale rol spelen. Uit een 'range' van mogelijke strategieën worden die gedragspatronen geselecteerd welke van maximaal nut zijn bij het reproduceren van genen en de overleving van individuen in een ecologische nis. De clou van dit idee is dat het nu mogelijk wordt om de aangepastheid van gedrag te onderzoeken zonder verwijzing naar het historische evolutieproces, namelijk via een kosten-baten analyse in termen van reproduktief succes. Men kan optimalisatietheorieën ontwerpen die voorspellen welke strategieën tenslotte de reproduktieve output van individuen maximaliseren. Dit stimuleerde niet alleen een nieuwe deductivistische onderzoeksstijl waarin modellenbouw een hoofdrol speelde, maar relativeerde ook het aangepastheidsbegrip. Die mathematische onderzoeksstijl zou een belangrijk onderdeel van de sociobiologie gaan vormen.

Het aangepastheidsbegrip werd verder gerelativeerd in het evolutionair-ecologisch onderzoek van David Lack. ${ }^{11}$ Hij vroeg zich af waarom vogels zo weinig eieren leggen als ze er veel meer kunnen leggen en vond dat natuurlijke selectie de legselgrootte afstemde op het ecologisch karakter van de omgeving. Er bestond een 'optimale' legselgrootte, waarvan niet al te $d r a s t i s c h$ kon worden afgeweken. Te grote legsels betekenden dat de ouders het broed onvoldoende konden voeden, waardoor een geringere bijdrage werd geleverd aan de volgende generatie. Te kleine legsels betekenden dat de omgeving niet optimaal werd benut en resulteerden op triviale wijze in een geringere bijdrage aan de nieuwe generatie.

Optimalisering van de legselgrootte via natuurlijke selectie illustreert het dynamische karakter van aanpassingsprocessen. Het gaat niet langer om aangepastheid per se, maar om strategieën die op langere termijn stabiel zijn en die rondom een bepaald evenwicht lluctueren. Fishers al veel oudere onderzoek naar de dynamische stabiliteit van de 
sexe-verhouding was hiervoor een maatgevend voorbeeld geweest (vergelijk hoofdstuk 1). Net als de wiskundige MacArthur had Fisher zich in zijn onderzoek gericht op constructie van een model dat de feitelijke situatie theoretisch kon verklaren.

Begin jaren zeventig begon Maynard Smith soortgelijke problemen in termen van speltheoretische modellen te formuleren. ${ }^{12}$ Zulke modellen zijn in feite toepassingen van de optimalisatietheorie op die gevallen waarin het gedrag van individuen afhankelijk is van andere individuen in de populatie (bijvoorbeeld vechteh of partnerkeuze). Er is dan niet eén optimale strategie die alle individuen zouden moeten toepassen, zoals bij fourageerstrategieën. Het probleem wordt dan een strategie te verzinnen die niet meer verdrongen kan worden door een hypothetische alternatieve strategie. Zo worden evolutionair stabiele strategieën ook gedefinieerd. Een evolutionair stabiele strategie (ESS) is een strategie die, wanneer de meeste individuen in een populatie haar toepassen, niet meer verdrongen kan worden door een mutante strategie. Er is met andere woorden geen alternatieve strategie denkbaar die voor individuen die haar toepassen een hogere 'fitness' oplevert.

De speltheoretische modellen die binnen de biologie zijn ontwikkeld wijken op een belangrijk punt af van de economische speltheoretische modellen. Von Neumann en Morgenstern, die de speltheorie hebben geformaliseerd met betrekking tot menselijk economisch gedrag, namen aan dat de spelers zich rationeel gedragen op basis van een bepaald economisch belang. In de toepassing van de speltheorie in een evolutionaire context worden deze aannames vervangen door evolutietheoretische uitgangspunten. Belang wordt in de biologische context vervangen door 'fitness'; het begrip 'rationeel handelen' vervangen biologen door een populatiedynamische terminologie.

Een van de bekendste voorbeelden van een ESS-model is het door Maynard Smith en Price ontwikkelde Havik-Duif model. ${ }^{13}$ In dit model worden een aantal vooronderstellingen gemaakt. Daarvan zijn de belangrijkste dat (1) er slechts twee strategieën (Havik en Duif) zijn zodat een zogenaamde 'payolf matrix' kan worden gemaakt, en (2) dat de winstverwachting voor beide tegenstanders gelijk is aan een $1 / 2$.

Uitgangspunt in het Havik-Duif model is de strijd tussen twee dieren om een natuurlijke bron. De Havik probeert een conllict te winnen met een groot risico voor zichzelf en zijn tegenstander. De Duif probeert door dreigen het conflict te winnen, maar trekt zich terug wanneer hij wordt aangevallen voórdat hij gewond kan worden. In deze situatie kan de 'fitness' van een dier worden verhoogd met een waarde $V$ wanneer het dier een gevecht wint, en worden verlaagd met een waarde $W$ wanneer een dier verliest en gewond wordt. Verder kan de 'fitness' 
worden verlaagd met een waarde $\mathrm{T}$ wanneer een dier door uitsluitend dreigen tracht te winnen. Indien we nu verder aannemen dat de kansen op een overwinning in een conflict tussen twee Havikken en twee Duiven gelijk zijn, kan een kosten-baten analyse worden gemaakt van de vier typen conflicten. In de onderstaande figuur staat de 'payoff matrix' weergegeven. Omdat een Duif zich in een conflict met een Havik terugtrekt, wordt aangenomen dat zijn 'fitness' niet verandert. De verandering in de 'fitness' van de duif is daarom 0.

$$
\text { Havik Duif }
$$

$\begin{array}{lcc}\text { Havik } & 1 / 2(\mathrm{~V}-\mathrm{W}) & \mathrm{V} \\ \text { Duif } & 0 & 1 / 2 \mathrm{~V}-\mathrm{T}\end{array}$

Wanneer we er verder nog vanuit gaan dat $\mathrm{W}$ groter is dan $\mathrm{V}$ zal in een populatie een stabiele verhouding tussen Havikken en Duiven ontstaan, waarbij het gemiddelde resultaat per conflict voor een Havik even hoog is als voor een Duif. Verdere analyse leert bovendien dat, indien de proportie Havikken $p$ is, de verdeling als volgt is: $p(1 / 2(V-W))$ $+(1-p) V=p(0)+(1-p)(1 / 2 V-T)$, en dus $p=(V+2 T) /(W+2 T)$. In een populatie kan dus een stabiele verhouding bestaan tussen twee strategieën.

Dit model laat zien dat een evolutionaire stabiele strategie mogelijk is in een populatie met Havikken die vechten met Duiven die geritualiseerd dreigen. Bovendien kan men aantonen dat noch een populatie die bestaat uit Havikken, noch een populatie die bestaat uit Duiven, een evolutionair stabiele strategie is, aangezien in een Havikkenpopulatie een mutante Duif en in een Duivenpopulatie een mutante Havik een hogere 'fitness' zullen hebben. Individuele selectie bevordert in dit theoretisch voorbeeld een 'gemengde ESS'.

Het Havik-Duif model is een voorbeeld van een symmetrisch conflict, dat wil zeggen dat de uitgangssituatie voor beide tegenstanders vergelijkbaar is. Zij hebben geen informatie over elkaars winstkansen; voor elk is de winstverwachting een $1 / 2$. Dit is natuurlijk een sterk vereenvoudigde voorstelling van zaken. In de natuur komen vaker asymmetrische conflicten voor, dat wil zeggen dat de uitgangssituatie voor individuen niet hetzellde is. Een van de tegenstanders kan groter en sterker zijn, of kan beschikken over een territorium. Van territoriumeigenaren mag worden verwacht dat zij, gezien de investering in het territorium, zich extra zullen weren in gevechten met indringers. Het Havik-Duif model kan aan deze complexere situalies geen recht doen. Parker en Maynard 
Smith ${ }^{14}$ hebben voor asymmetrische conflicten een model ontwikkeld ent beargumenteerd dat in deze situatie informatie-overdracht kan plaatsvinden over de 'resource holding potential'(RHP), zoals bijvoorbeeld over de kracht van de tegenstanders of over het territoriumbezit. Informatie-overdracht over bedoelingen was echter geen ESS zo voorspelde de theorie. Deze voorspelling zou het onderwerp worden van een controverse tussen speltheoretici en ethologen.

Het Havik-Duif model van Maynard Smith en Price en het model van Parker en Maynard Smith zijn voorbeelden van theoretische modellen die binnen de sociobiologische onderzoekstraditie zijn ontwikkeld. Rondom deze speltheoretische modellen is de discipline geleidelijk ontstaan. Binnen deze onderzoekstraditie houdt men zich bezig met de vraag door welke evolutionaire processen sociaal gedrag is ontstaan en gehandhaafd blijft. Voortgekomen uit louter biologische onderzoekstradities, is de sociobiologie een onmiskenbaar produkt van de aanlegstijl. Sociobiologen onderzoeken de ultimate-oorzaken van gedrag: waarom zijn bepaalde gedragingen in de evolutie ontstaan en waarom worden die gedragingen niet verdrongen door alternatieve gedragingen? Ook ethologen onderzoeken natuurlijk de ultimate-oorzaken van gedrag, maar in de speltheoretische benadering ontbreekt de historische verwijzing die kenmerkend is voor de ethologische benadering. Door deze ahistorische nadruk op ultimate-oorzaken, zoeken sociobiologen hun verklaringen vaak in gen-centrische modellen. Uiteindelijk gaat het om aanpassingen op het niveau van de genen. ${ }^{15}$ In het speltheoretisch onderzoek bijvoorbeeld vraagt men zich af welke strategieën niet meer verdrongen kunnen worden door (hypothetische) mutante strategieën. De eenheden van evolutie in speltheoretische modellen waarop wordt geselecteerd zijn genen. Evolutie is dan een proces dat wordt gestuurd door selectie op genen, waarbij de dragers van die genen alleen een bemiddelende rol spelen. De concurrentie tussen genen (via de dragers) krijgt prioriteit.

Het gen-centrisch perspectief van de sociobiologie heeft de traditie esoterisch een eigen gezicht gegeven. Een aantall belangrijke probleemverschuivingen waren hiervan het gevolg. Seksuele selectie bijvoorbeeld werd traditioneel als een aparte categorie naast natuurlijke selectie gezien. Op genniveau is het alleen een speciale categorie binnen natuurlijke selectie: in beide gevallen neemt de relatieve frequentie van bepaalde genen toe omdat hun dragers een hogere 'fitness' hebben. De sociobiologie heeft haar autonomie binnen de biologie echter niet alleen te danken aan deze inhoudelijk ideeën. Typisch is niet alleen dat het zoeken naar ultimate-oorzaken gekoppeld is aan een gen-centrisch perspectief, maar ook aan een deductieve onderzoeksstijl. Sociobiolo- 
gen beginnen hun onderzoek met een aantal eenvoudige aannames en ontwikkelen met behulp van een wiskundige heuristiek toetsbare consequenties. De ontwikkeling van modellen bepaalt welke feiten met welke maat van precisie van belang zijn. De wiskundige heuristiek zorgt ervoor dat de spelt heoretici -in de woorden van Lakatos- niet in de war worden gebracht door de zee van anomalieën waarin de speltheoreti* sche modellen zich bevinden. In deductieve tradities kijkt men niet vreemd op van anomalieën, omdat de wiskundige heuristiek functioneert als strategie 'both for predicting (producing) en digesting them' ${ }^{16}$ De problemen die onderzoekers ontmoeten zijn eerder wiskundig van aard dan empirisch.

De feit-onafhankelijk wiskundige heuristiek bewees haar kracht in een controverse tussen ethologen en sociobiologen. Nadat de sociobiologie zich in eerste instantie onafhankelijk van het ethologisch onderzoek had ontwikkeld, bleek het speltheoretisch onderzoek eind jaren zeventig - in Lakatosiaanse termen - een monster of tegenvoorbeeld te hebben voortgebracht dat de aanleiding was voor een debat tussen ethologen en sociobiologen. Via de wiskundige heuristiek werd zoals we zullen zien een oplossing gegenereerd voor de problemen.

\section{4 \\ Sociobiologie versus ethologie}

De controverse tussen ethologen en sociobiologen die eind jaren zeventig ontstond ging over de vraag of dieren in conflicten informatie uitwisselden over bedoelingen. Ethologen waren -impliciet dan wel expliciet- er vanuit gegaan dat dit het geval was, terwijl sociobiologen op grond van speltheoretisch onderzoek concludeerden dat er geen informatie over bedoelingen werd uitgewisseld. Deze twee verschillende theoretische posities hangen nauw samen met de verschillen tussen de sociobiologische en ethologische onderzoeksstijl.

De ethologische onderzoeksstijl gaat terug op Darwins The Expression of Emotions in Man and Animals. Darwin liet zien dat emoties karakteristieke uitdrukkingen in het gedrag van dieren en mensen hebben. Mensen en dieren toonden hun emoties; uit gebaren en gelaatsuitdrukkingen kon men de gemoedstoestand als het ware aflezen. De vroege ethologen gebruikten in hun onderzoek het pantomimespel als model voor hun onderzoek. Dieren toonden hun emoties als pantomimespelers en het was de taak van de bioloog om op grond van het gedrag het achterliggende karakter te onderzoeken. Deze analogie-redenering tussen dieren en pantomimespelers werd later door met name Lorenz 
"gezuiverd" van antropomorfe connotaties. Lorenz legde de nadruk op de vorn van gedragingen waardoor (menselijke) psychologische predicaten overbodig werden. ${ }^{17}$ De vorm van gedragingen kan men immers "neutraal" benoemen en beschrijven zonder gebruik te maken van menselijke psychologische predicaten. Maar gedrag is een activiteit; een gedragspatroon lijkt erop gebouwd om een bepaalde functie te verrichten. Dit aspect van diergedrag kan moeilijker worden gezuiverd van antropomorfismen. Men kan het feit dat een hond de tanden ontbloot en gromt objectief onderzoeken door de vorm van dit gedragspatroon te beschrijven. Het gedragspatroon heeft echter in de terminologie van Karl Bühler een expressieve functie en een signaalfunctie. ${ }^{18}$ De hond die de tanden ontbloot en gromt laat zien dat hij 'boos' is en dat 'signaal' heeft een communicatiefunctie in de interacties tussen dieren. De expressieve functie en de signaalfunctie zijn veel moeilijker in niet-antropomorfe termen te interpreteren. Op dit vlak gebruikten ethologen dan ook vaak analogie-redeneringen met menselijk gedrag voor de ontwikkeling van ideeën.

De verhouding tussen vorm-aspecten en functie-aspecten is afhankelijk van de probleemsituatie. Dit kan aan de hand van een drietal voorbeelden worden geîllustreerd: (1) de verklaring van de vorm van verschillende gedragingen,(2) de verklaring van de communicatie-functie van gedrag, en (3) de verklaring van de overlevingswaarde van gedragingen.

(1) Voor de verklaring van de vorm van verschillende gedragingen heeft Tinbergen zijn bekende conllicthypothese ontworpen. ${ }^{19}$ Tijdens onderzoek naar onder andere de driedoornige stekelbaars zag Tinbergen dat gedragspatronen in bepaalde opzichten op elkaar lijken. De mannetjes van de stekelbaars bijvoorbeeld vertonen tijdens de balts 'geritualiseerde gedragspatronen', waarvan de 'zig-zag dlans' een typisch voorbeeld is. Tijdens de 'zig-zag dans' zwemt het mannetje afwisselend naar het wijfje toe en van het wijfje weg. De 'zig-zag dans' wordt soms gevolgd door een aanval op het wijfje, soms door 'leiden', dat wil zeggen dat het mannetje van het wijfje wegzwemt in de richting van het nest. Op basis van deze waarnemingen kwam Tinbergen op het idee dat de 'zig-zag dans' is samengesteld uit twee intentiebewegingen, namelijk aanvallen en leiden. Men kan in de 'zig-zag dans' de intenties tot aanvallen en leiden herkennen. De conflicthypothese zegt nu dat de 'zig-zag dans' in de evolutie is ontstaan uit de oudere gedragingen 'aanvallen' en 'leiden'. De ambivalentie tussen de functioneel gezien tegengestelde neigingen 'aanvallen' en 'leiden' heeft in het geval van de 'zig-zag dans' geresulteerd in een herhaalde alternatie van deze twee gedragspatronen. Dat hoeft trouwens niet te resulteren in een herhaalde 
alternatie; er zijn ook voorbeelden die cerder een 'compromis' zijn tussen functioneel tegengestelde gedragspatronen.

Hoewel de conflicthypothese in eerste instantie is ontworpen voor de verklaring van de vorm van geritualiseerde gedragspatronen; wordt in de verklaring gebruik gemaakt van ideeèn over de functie van gedragingen. Het conflict tussen functioneel tegengestelde neigingen is volgens de hypothese de causale basis voor het ontstaan wan geritualiseerde gedragspatronen.

(2) Wanneer we expliciet vragen wat de communicatiefunctie van 'geritualiseerde gedragspatronen' is, wordt de vorm van gedragspatronen in de theorievorming minder belangrijk. In de ethologische theorievorming werden de vragen en antwoorden op dit vlak gestructureerd door de analogie met het pantomimespel. Wij zijn in staat om de bedoelingen van pantomimespelers af te leiden uit hun gebaren en gelaatsuitdrukkingen. Dit leidt tot de vraag of ook dieren hun bedoelingen zo overbrengen en of soortgenoten deze begrijpen. Volgens de ethologen was dit het geval: 'An experienced ethologist can usually predict what an individual will do next from its behaviour at a given moment. (...) If we can interpret intention movements, it seems highly probable that other members of the same specifies can do so' ${ }^{20}$ Onderzoek van Stokes, Dunham en Andersson leek deze hypothese te bevestigen. ${ }^{21} \mathrm{Zij}$ meenden te hebben aangetoond dat informatieoverdracht over bedoelingen via gedragspatronen belangrijk was in de communicatie tussen dieren.

(3) Problemen rond de overlevingswaarde van geritualiseerde gedragspatronen werden gestructureerd door de romantische achtergronden van het naturalisme in de ethologie. Ethologen benadrukten dat zij harmonieus verlopende interacties tussen soortgenoten waarnamen. ${ }^{22}$ Veel gevechten waren geritualiseerd tot spiegelgevechten waarbij zelden dieren werden gedood of ernstig verwond. Dergelijke fenomenen verleidden ethologen ertoe om vormen van groepsselectie te verdedigen. Sociaal gedrag ontstaat in die visie als aanpassing aan de groep en is gericht op het welzijn van de groep als geheel. In geritualiseerde gevechten worden geen individuen opgeofferd, opdat de groep als geheel een groter voortplantingssucces heeft.

Toen de groepsselectietheorie eind jaren zestig ineenstortte, nadat met name Williams en Maynard Smith ${ }^{23}$ hadden laten zien dat aan de voorwaarden van deze selectievorm zelden of nooit wordt voldaan, begonnen sociobiologen alternatieve verklaringen voor de functie van geritualiseerde gedragspatronen te ontwikkelen. In tegenstelling tot de empiristische benadering van de ethologen gingen zij louter theoretisch te werk. Dit verschil in onderzoeksstijl kan worden geillustreerd aan de 
hand van het verschil tussen bet Havik-Duif model en de conflict-hypothese. In het Havik-Duif model probeert Maynard Smith strategieen te deduceren die niet verdrongen kunnen worden door hypothetisch mutante strategieën. De witkonst van het theoretisch onderzoek is dat geritualiseerd dreigen (Duif) en vechten (Havik) een ESS is. Geritualiseerd dreigen wordt in het Havik-Duif model voorspeld en kan alleen onder bepaalde omstandigheden optreden. Tínbergen gaf een geheel andere verklaring voor geritualiseerd dreigen. Uitgangspunt in Tinbergens onderzoek was het waarneembare dreiggedrag. Hij wroeg zich af hoe de versehillende vormen van dreiggedrag (en baltsgedrag) konden worden verklaard. Door dit onderzoeksprobleem in termen van de evolutietheorie te herformuleren ontwikkelde Tinbergen zijn conflicthypothese. De kern van beider strategieën kunnen we als volgt tegenover elkaar zetten. Maynard Smith gebruikt de speltheorie als een zoeklicht voor het deduceren van evolutionair stabiele strategieën, terwijl Tinbergen de evolutictheorie als een fonds gebruikte voor de interpretatie van fenomenen.

Het verschil tussen de inductivistische, ethologische benadering en de deductivistische, speltheoretische benadering, resulteerde niet alleen in verschillen in de logische structuur van theorieën, maar had ook inhoudelijke verschillen tot gevolg. Sociobiologen begonnen hun onderzoek niet bij de vorm maar bij de functie van gedrag. Net als de ethologen gebruikten speltheoretici natuurlijk analogieën met menselijk gedrag voor de ontwikkeling van ideeën, maar zij stelden andere eisen aan de ontwikkelde hypothesen. Een ontwikkelde hypothese moest omgewerkt worden tot een toetsbaar speltheoretisch model. Wanneer deze laatste stap niet lukte, dan waren de ontwikkelde hypothesen volgens Maynard Smith 'inadmissible'. ${ }^{24}$ Het verschil tussen de ethologische benadering en de speltheoretische benadering ligt dus niet in het al dan niet gebruiken van analogie-redeneringen. Het verschil komt voort uit de wijze waarop men hiermee omgaat. Een etholoog zal op basis van analogie-redeneringen een hypothese ontwerpen en die vervolgens zoveel mogelijk proberen te 'zuiveren' van antropomorfe connotaties, door de hypothese in termen van geaccepteerde kennis te herformuleren zonder gebruik te maken van psychologische predicaten. Speltheoretici stellen in feite strengere eisen aan een hypothese. $\mathrm{Zij}$ streven naar een speltheoretisch model dat bepaalde zaken verbiedt: alleen hypotheses die zijn omgewerkt tot een toetstbaar speltheoretisch model zijn vruchtbaar.

Dit abstracte verschil tussen de ethologische en sociobiologische benadering kan concreet worden gemaakt aan de hand van de controverse over de functie van 'displays'. De aanleiding voor deze controverse 
was een door Maynard Smith geproduceerd monster. Op grond van de analogie-redenering met het pantomimespel hadden ethologen geopperd dat informatie-overdracht van bedoelingen voorkwam tijdens de conflicten tussen dieren. Met een relatief eenvoudig gedachtenexperiment liet Maynard Smith zien dat een dergelijke eerlijkheid geen evolutionair stabiele strategie kon zijn. ${ }^{25}$ Stel dat de ethologische hypothese zou kloppen. Wanneer een dier dan een sterk dreigsignaal geeft, kan de opponent risico's vermijden door zich uit het strijdperk terug te trekken. Zo'n eerlijke populatie zou volgens Maynard Smith niet opgewassen zijn tegen een mutant die altijd, ongeacht zijn bedoelingen, het sterkste dreigsignaal geeft. Die mutant zou namelijk elk conflict zonder escalatie in zijn voordeel beslissen omdat tegenstanders zich zouden terugtrekken. Maynard Smith concludeerde dan ook dat informatie-overdracht over bedoelingen geen evolutionair stabiele strategie kan zijn en hij verwachtte dat de bedoelingen van tegenstanders altijd verhuld blijven. In plaats van de romantisch-naturalistische kijk op conflicten leverde de speltheoretische analyses dus een veel cynischer kijk.

Dit theoretisch inzicht, dat alleen was gebaseerd op de logica van de speltheorie, was dus in strijd met de ethologische ideeën. Dit bleef in esoterische kringen natuurlijk niet onopgemerkt. De sociobiologen Dawkins en Krebs begonnen daarom het ethologisch materiaal opnieuw te bekijken. ${ }^{26}$ Volgens hen kon het begrip 'informatie' wel weggeselecteerd worden, aangezien 'eerlijke' informatie-overdracht over bedoelingen niet voorkwam. In hun 'cynical gene view' is alleen nog sprake van manipulatie. Individuen komen slechts op voor hun eigen genen en manipuleren via sluwe strategieën ouders, prooien, seksuele partners en rivalen. Caryl werkte het model 'War of Attrition" verder uit en testte dit model aan de hand van de resultaten van het onderzoek van Dunham, Stokes en Andersson. ${ }^{27}$ Het model voorspelde dat dreiggedrag wel informatie over de kansen op een vlucht mocht geven, maar geen informatie over de kansen op een aanval. Door het werk van de ethologen te heranalyseren, liet Caryl zien dat op grond van dreiggedrag niet kon worden voorspeld of dieren daarna zouden aanvallen, en kritiseerde daarmee de eerdere interpretaties van de ethologen. Dunham, Stokes en Andersson hadden op basis van hun studies geconcludeerd dat 'eerlijke' informatie-overdracht van bedoelingen wél voorkwam.

Het debat over deze kwestie werd in de jaren tachtig voortgezet en is nog niet volledig beslist. Wel is er een aantal interessante bijdragen geleverd waarvan ik twee typen zal analyseren: monsteraanpassingen en monsterassimilaties. ${ }^{28}$ Wanneer onderzoekers volgens Lakatos monsters aanpassen, dan proberen zij een anomalie met hulphypothesen zodanig te veranderen dat de oorspronkelijke theorie kan worden 
gehandhaafd. Bij het assimileren van anomalieën wordt zowel het tegenvoorbeeld als de theorie waar het een weerlegging van was herzien.

Hinde was de eerste etholoog die de kritiek van de sociobiologen beantwoordde. ${ }^{29}$ Hij betoogde dat de kritiek van met name Dawkins, Krebs en Caryl niet terecht was omdat 'displays' noait precieze informatie geven over bedoelingen.

'The very fact that a threat display can be followed by more than one type of behaviour (...), implies that displays could not carry precise information about what the displaying individual will do next'. ${ }^{30}$

Dreiggedrag kan betekenen: 'ik val aan', maar ook: 'ik blijf dreigen of ik val aan'. Dit verklaarde volgens Hinde waarom op grond van 'displays' niet kon worden voorspeld of een dier ging aanvallen en het bleef de vraag of eerlijke informatie-overdracht over bedoelingen voorkwam. In zijn repliek merkte Caryl op dat de aanpassingen van Hinde niet ter zake waren. De vraag of 'displays' geen precieze informatie geven was volgens hem niet de kwestie waar het om ging: '... what is at issue is whether any information is available which could be transferred in this way. ${ }^{31}$ Het sociobiologisch antwoord bleef volgens Caryl, ook na de aanpassingen van Hinde, dat er geen informatie-overdracht over bedoelingen werd gegeven.

Van Rhijn en Vodegel assimileerden de kritiek van de sociobiologen. $\mathrm{Zij}$ accepteerden de kritiek en gebruikten het tegenvoorbeeld voor een creatieve probleemverschuiving. Van Rhijn en Vodegel ontwikkelden een speltheoretisch model waarin informatie-overdracht over toekomstig gedrag (dus bedoelingen) een ESS kan zijn. ${ }^{32}$ Uitgangspunt in hun model is dat er in de natuur vaak (asymmetrische) conflicten tussen dezelfde individuen plaatsvinden. In dat geval ontstaat de mogelijkheid dat dieren elkaar individueel leren herkennen. Met behulp van de speltheorie lieten zij vervolgens zien dat, indien individuele herkenning een rol speelt, informatie-overdracht over bedoelingen een evolutionair stabiele strategie is mits: $(1)$ de tegenstanders elkaars krachten vrij nauwkeurig kunnen vaststellen, (2) de kosten van een krachtmeting hoger zijn dan het geven van betrouwbare informatie, en (3) een individu zijn winstkansen niet aanmerkelijk kan verhogen door als eerste aan te vallen in een conflict. Op grond van hun model voorspelden van Rhijn en Vodegel dat de eerste conflicten vermoedelijk krachtmetingen zullen zijn en dat in latere conflicten eerst een betrouwbare waarschuwing (die begrepen moet worden) zal worden gegeven voordat het tot een gevaarlijke confrontatie komt. Een soortgelijke oplossing werd een jaar later voorgesteld door Axelrod en Hamilton: zij ontwikkelden een algemeen 
speltheoretisch model (Tit for Tat), gebaseerd op het Prisoner's Dilemma, ter verklaring van de evolutie van samenwerking watarin individuele herkenning eveneens centraal stond: ${ }^{33}$

In het debat naar aanleiding van het speltheoretisch model van van Rhijn en Vodegel stond het model zelf niet ter discussie, maar ging het om de vraag via welke gedragingen betrouwbare informatie-overdracht plaatsvond. ${ }^{34}$ De controverse over het model werd met andere woorden gerelateerd aan specifieke gedragssamples voor 'displays'. Van Rhijn en Vodegel hadden in hun model geen onderscheid gemaakt tussen geritualiseerde 'displays' en niet-geritualiseerde gedragingen en verwezen ter ondersteuning van hun model naar een empirische studie van Bossema en Burgler naar dreiggedrag van vlaamse gaaien. Daarin werd volgens hun aangetoond dat betrouwbare informatie werd gegeven via niet-geritualiseerde gedragingen ('subtile actions'), maar waren tevens van mening dat óók geritualiseerde 'displays' daarvoor in aanmerking kwamen. Hoewel er volgens Maynard Smith nog wel het een en ander viel op te helderen, accepteerde hij de voorstellen van van Rhijn en Vodegel. Caryl daarentegen niet: hij hield vast aan de these dat via geritualiseerde 'displays' geen informatie-overdracht over bedoelingen kon plaatsvinden. Deze conclusie beargumenteerde hij aan de hand van de dezelfde gegevens uit de studie van Bossema en Burgler naar het dreiggedrag van vlaamse gaaien.

De controverse over de functie van 'displays' werd in de jaren tachtig zowel op theoretisch als op empirisch niveau verder voortgezet. ${ }^{35}$ Voor deze studie is de discussie al voldoende ver gevorderd om een aantal wetenschapstheoretische lessen te trekken. Daarvoor zal ik een aantal aspecten van het debat samen met de analyse van het debat tussen ethologen en psychologen uit het hoofdstuk 3 bespreken.

\section{5 \\ Conclusies}

Vanuit een wetenschapstheoretisch oogpunt zijn er geen grote verschillen aan te wijzen tussen het debat tussen ethologen en psychologen en het debat tussen sociobiologen en ethologen. In beide debatten vinden we de twee belangrijkste Lakatosiaanse strategieën terug: 'monsteraanpassingen' en 'monsterassimilaties'. De wijze waarop de monsters werden gegenereerd verschilde echter. In het debat tussen ethologen en sociobiologen werd het monster via een wiskundige heuristiek gegenereerd, in het debat tussen ethologen en behavioristen via puzzel- 
oplossen. Tevens werd in het geval van de speltheorie een oplossing voor het probleem gegenereerd vila de wiskundige heuristiek.

Net als bij het debat tussen ethologen en behavioristen, werd ook hier in esoterische kringen overeenstemming bereikt tussen vertegenwoordigers van twee verschillende theoretische perspectieven, bijvoorbeeld tussen van $\mathrm{Rhijn}$ en Maynard Smith. Tussen ethologen en sociobiologen zijn samenwerkingsverbanden ontstaan. Hoewel speltheoretici in eerste instantie voorbij gingen aan de resultaten van het ethologisch onderzoek, veranderde dat na verloop van tijd. De discussie verplaatste zich deels naar het niveau van de concrete onderzoeksresultaten. Dit laat nog eens de waarde van het sample-begrip voor de wetenschapstheorie zien: hiermee kan inzicht worden gegeven in de gelaagdheid van de discussie. Naast een theoretische discussie verliep de discussie via de samples voor gedragspatronen die daarmee voor een gemeenschappelijk element zorgden. In de discussies zelf zijn deze twee niveau's natuurlijk nauwelijks uit elkaar te trekken.

Het meest opvallende verschil tussen de twee debatten is de rol van de wiskundige heuristiek in de controverse tussen speltheoretici en ethologen. Via deze heuristiek werden bepaalde onderzoeksresultaten relevant gemaakt. Niet de onderzoeksdata waren bepalend voor de theorie, maar de data moesten wijken voor de theorie. Eerst werd het eenvoudige Havik-Duif model ontwikkeld, daarna modellen voor asymmetrische conflicten, en nog later werden modellen ontwikkeld waarin informatie-overdracht over bedoelingen mogelijk waren. De uitbouw van de sociobiologische traditie werd in eerste instantie goeddeels door een interne dynamiek gestuurd. Empirische gegevens werden pas later relevant voor de verdere uitwerking van de speltheoretische modellen. Dit komt zeer pregnant naar voren in de wijze waarop speltheoretici reageerden op het monster. Het gegenereerde monster functioneerde binnen de speltheorie als een trigger: het was een reden om de speltheorie via de wiskundige heuristiek verder uit te werken. Nieuwe empirische gegevens speelden hierbij geen belangrijke rol. Voor ethologen daarentegen, die juist een feit-allhankelijk heuristiek hanteerden, was het monster een anomalie dat fungeerde als een stimulus voor nader onderzoek. De oudere ethologische data waren niet langer bruikbaar voor de interpretaties van de communicatiefuncties van gedragingen en moesten vervangen worden door nieuwe. De vraag rees bijvoorbeeld of individuele herkenning inderdaad belangrijk was bij het al dan niet uitwisselen van informatie over bedoelingen en daarvoor dienden ethologen de gedragsveranderingen van dieren als gevolg van gedragsveranderingen van hun opponenten nauwkeuriger te onderzoeken. Dat ethologen voor de interpretatie van de data steeds vaker gebruik zijn gaan 
maken van speltheoretische modellen, laat zien dat zij nog steeds inductief te werk gaan. De speltheoretische modellen zijn onderwijl een fonds geworden voor de interpretatie van empirische gegevens. 


\title{
6 \\ Immunologie tussen struc- tuur en functie
}

\author{
6.1 \\ Inleiding
}

In deze eeuw is de meest spectaculaire kennisgroei in de levenswetenschappen zonder twijfel bewerkstelligd binnen de moleculaire biologie. De ontdekking van de DNA-structuur, gevolgd door het breken van de genetische code en de ontdekking van de eiwitsynthese, zijn misschien wel de grootste successen. Deze kennisgroei heeft uiteindelijk geleid tot de genetische manipulatie waarvan menigeen nog veel verwacht. In haar kielzog heeft de moleculaire biologie een aantal vakken meegetrokken, waaronder de immunologie. Ook dit vak heeft een stormachtige ontwikkeling doorgemaakt waarvan het einde voorlopig nog niet in zicht is.

Binnen de immunologie hebben theorieën elkaar in een snel tempo afgewisseld. Na Ehrlichs zijketentheorie volgden verschillende instructietheorieën, Burnets analogie met adaptieve enzymen, Jerne's natuurlijke selectietheorie, en Burnets klonale selectietheorie. De rij wordt voorlopig gesloten door Jerne's netwerktheorie. De grote doorbraak vond plaats in de jaren vijftig en zestig, toen de chemische instructietheorieën gaandeweg het veld ruimden voor de biologische aanlegtheorieën van Burnet en Jerne. Volgens de instructietheorie leert een organisme een ziekteverwekker herkennen doordat de ziekteverwekker het organisme instrueert. Pas na contact met de ziekteverwekker ontstaat de specifieke immuniteit. In de biologische traditie werd het ontstaan van immuniteit uiteindelijk verklaard met de selectietheorie. Volgens deze (darwinistische) selectietheorie is de specifieke immuniteit al in beginsel aanwezig vórdat het organisme in contact komt met de specifieke ziekteverwekker. De ziekteverwekker is alleen een 'trigger' voor al aanwezige immuniteit. 
De instructietheorie en de selectietheorie zijn twee tegengestelde visies op de specificiteit van de immunologische reactie. Voor instractietheoretici was de specificiteit van de immunologische reactie een empirisch-chemisch probleem dat in termen van geaccepteerde chemische kennis over de structuur van moleculen kon worden geïnterpreteerd. Voor selectietheoretici zou het specificiteitsprobleem een chemisch probleem worden. Net als in de moleculaire biologie zou binnen de biologische traditie een nieuw specificiteitsbegrip worden ontwikkeld. ${ }^{1}$ De kern van de nieuwe theorie werd een modificatie van Cricks centrale dogma dat de aminozuurvolgorde van eiwitten verklaart in termen van genetische informatie.

In dit hoofdstuk wordt de opkomst van de moderne selectietheorie tegen de achtergrond van de oudere instructietheorie onderzocht. In de biologische traditie stelde men in eerste instantie de functie van de afweer centraal in het onderzoek. Men problematiseerde een 'alledaags" principe van de immuniteit dat tot dan toe geen rol van betekenis had gespeeld in de immunologische theorievorming: waarom produceren organismen antilichamen tegen 'niet-eigen' elementen maar niet. tegen 'eigen' elementen? Dit onderscheidend vermogen van de afweer heeft vanuit een biologisch oogpunt een duidelijke overlevingswaarde en moest daarom volgens biomedici worden verklaard. Chemici hadden dit principe nooit geproblematiseerd. Hierdoor ontstond er in eerste instantie een kloof tussen de biologische, functionalistische benadering en de chemische, structuralistische benadering, die pas na de opkomst van de moleculaire biologie werd gedicht. Deze laatste ontwikkeling resulteerde uiteindelijk in het nieuwe biologische specificiteitsbegripen de definitieve teloorgang van de instructietheorie. De wijze waarop dat gebeurde wordt in dit hoofdstuk onderzocht. De spanning tussen de structuralistische en de functionalistische benadering zal worden gebruikt om de onderlinge verhouding van de chemische en de biologische tradities nader te analyseren.

Tevens zal de vraag gesteld worden in hoeverre verschillen tussen de natuur- en de levenswetenschappen consequenties hebben voor de wijze waarop het aanleg-omgeving vraagstuk wordt aangepakt. Typisch voor de immunologie is dat dit vakgebied zich bevindt in een grensgebied tussen de biologie en de chemie. Terwijl in de ethologie en de sociobiologie het aanleg-omgeving vraagstuk betrekking had op gedrag, spelen in de immunologie verscheidene organisatieniveaus een rol. Het grootste verschil tussen de ethologie, sociobiologie en de immunologie komt voort uit het feit dat bij het specificiteits-probleem in de immunologie een moleculair niveau in het geding is. Er worden samples van chemische stoffen gebruikt, die in het experimenteel onderzoek op een 
andere wijze functioneren dan de samples die ethologen voor gedrag gebruiken. Welke consequenties hebben deze verschillen voor de manier waarop chemici en biologen omgaan met het aanleg-omgeving vraagstuk? Dat zal ik in dit hoofdstuk onderzoeken.

\section{2 Voorgeschiedenis}

De instructietheorie was in het begin van de jaren dertig ontworpen als een alternatief voor de oudere, speculatieve zijketentheorie van Ehrlich. ${ }^{2}$ Een van de postulaten van Ehrlichs theorie was dat organismen van nature antilichamen (preciezer: antitoxinen) bezitten die als receptoren waren verbonden aan de membranen van cellen. $\mathrm{Na}$ het werk van Landsteiner raakte de zijketentheorie in discrediet. ${ }^{3}$ In uitgebreid empirisch onderzoek liet Landsteiner zien dat organismen antilichamen kunnen vormen tegen een breed scala aan synthetische stoffen. Bovendien bleek de chemische structuur van die synthetische stoffen medebepalend voor de specificiteit van de immunologische reactie. Landsteiner en van der Scheer toonden in hun haptenen-onderzoek aan dat kleine variaties in de chemische structuur consequenties hadden voor de immunologische reactie. De configuratie van haptenen (een klein molecuul, gekoppeld aan een drager-eiwit) bleek zelfs van cruciaal bellang, aangezien ortho-, meta- en para-isomeren van haptenen verschillende immunologische reacties teweeg brachten. Deze resultaten leken slecht te passen bij de zijketentheorie van Ehrlich omdat in die theorie was uitgegaan van een zeer beperkt aantal antilichamen. De scope van de immunologische reacties was veel breder dan men op grond van Ehrlichs theorie zou vermoeden zodat een eenvoudig, natuurlijk afweermechanisme ontoereikend leek voor de verklaring van de specificiteit van die reacties.

Het haptenen-onderzoek van Landsteiner maakte de weg vrij voor wat later werd genoemd - de instructietheorie. 'Es ist unvorstellbar, dass der Organismus lür Tausende derartiger künstlich erzeugbare Stoffe ständig Antikörper erzeugt ${ }^{4}$, concludeerden Breinl en Haurowitz naar aanleiding van Landsteiners onderzoek. Ook anderen trokken die conclusie en verwierpen Ehrlichs idee dat organismen 'gepreformeerde' antilichamen bezitten. Deze gedachte werd binnen de fysisch-chemische traditie binnen de immunologie gemeengoed en bleef dat tot in de jaren zestig.

Hoewel chemici Ehrlichs theorie verwierpen, werd die in eerste instantie niet vervangen door een nieuwe theorie die als leidraad kon 
functioneren voor verder onderzoek. In plaats daarvan kozen fysischchemici voor een inductieve benadering. Vanaf de jaren twintig probeerde men de klassieke immunologische reacties, zoals precipitatie en agglutinatie, verder chemisch te onderzoeken. Hierbij gebruikte men, in navolging van Landsteiner, chemische substanties omdat die in de vorm van zuivere samples te verkrijgen zijn en in het experimenteel onderzoek eenvoudiger zijn te manipuleren dan virussen of bacteriën. Door bepaalde moleculen te koppelen aan drager-eiwitten kon men de affiniteit tussen antigenen en antilichamen verder analyseren. Vernieuwingen binnen deze fysisch-chemische traditie bestonden voornamelijk uit de introductie van nieuwe technieken, die niet werden ontworpen naar aanleiding van theoretische ontwikkelingen, maar 'geleend" wer* den van naburige chemische kringen. Een voorbeeld is de equilibrium dialyse, waarmee de associatie-constante van de reversibele reactie tussen antigeen en antilichaam kon worden bepaald. De instructietheorie die in deze traditie werd ontwikkeld sloot nauw aan bij deze experimentele benadering van immunologische fenomenen. Omdat men werkte met chemische stoffen en technieken, gebruikte men voor de interpretatie van waargenomen effecten het fonds van chemische kennis. In het experimenteel onderzoek onderzocht men de affiniteit tussen antigeen en antilichaam door variaties aan te brengen in de chemische structuur van de antigenen (omgeving); in de theorievorming probeerde men de specificiteit van de reactie te verklaren uit de vormende invloed van het antigeen op de bouw en synthese van antilichamen. Deze gedachtengang werd voor het eerst expliciet uitgewerkt door Breinl en Haurowitz in $19300^{5} \mathrm{Zij}$ postuleerden dat antigenen al in een vroeg stadium van de normale globulinen-synthese interfereerden met het mechanisme van de synthese, namelijk in die fase waarin de aminozuren aaneengeschakeld worden tot een globuline-molecuul. Onder invloed van het antigeen zou volgens Breinl en Haurowitz de aaneenschakeling anders verlopen waar door een nieuw molecuul wordt gevormd: een antilichaam. De invloed van het antigeen weten zij aan specifieke intermoleculaire krachten, zoals electrostatische interacties.

Deze theorie van Breinl en Haurowitz verklaarde op betrekkelijk eenvoudige wijze de specificiteit van de immunologische reactie. Aangezien verschillende antigenen op verschillende wijze het vormingsproces van antilichamen beinvloeden, verklaarde de theorie waardoor organismen antilichamen kunnen vormen tegen een grote diversiteit aan natuurlijke en synthetische antigenen. De specifieke affiniteit tussen een antigeen en een antilichaam werd verder verklaard door aan te nemen dat de zogenaamde determinante groep van het antigeen tijdens de synthese de vorm van het antilichaam bepaalt. $\mathrm{Na}$ de synthese zou het 
antilichaam dan een "bindingsplaats' bezitten die complementaï was aan de determinante groep.

Deze instructietheorie werd in 1940 door Pauling verder uitgewerkt. ${ }^{6}$ Uitgaande van theoretische overwegingen probeerde Pauling met de voor hem zo typerende deductieve benadering de vorming van antilichamen te interpreteren in termen van inter- en intra-moleculaire krachten, sterke en zwakke bindingen, etcetera. De resultaten van fysisch-chemisch onderzoek gebruikte Pauling hierbij niet als uitgangspunt voor zijn theorie, maar als gegevens waaraan zijn speculatieve theorie al tijdens het opstellen werd getoetst. Twee vragen stonden in zijn onderzoek centraal: 'what is the simplest structure which can be suggested, on the basis of the extensive information now available about intramolecular and intermolecular forces, for a molecule with the properties observed for antibodies, and what is the simplest reasonable process of formation of such a molecule? ${ }^{7}$ Voor de beantwoording van deze vragen ging Pauling uit van de veronderstelling dat alle antilichamen dezelfde aminozuursequentie hadden, en vecwierp daarmee de theorie van Breinl, Haurowitz en Mudd dat antigenen de aminozuurvolgorde van immuunglobulinen kunnen beinvloeden. De verschillen tussen de antilichamen konden volgens Pauling worden verklaard uit de verschillende configuraties van de polypeptideketens. Hoewel Pauling schreel dat hij geen mechanisme kon bedenken waardoor antigenen de aminozuurvolgorde van immuunglobulinen konden beinvloeden, ontleende hij deze gedachte aan Landsteiner en Rothen die al in 1939 hadden geopperd dat alle immunglobulinen dezelfde aminozuurvolgorde hadden (zij baseerden zich overigens weer op eerder werk van Pauling en Mirsky aan polypeptideketens). ${ }^{8}$

De kern van Paulings theorie was dat de antilichaamvorming in twee fasen verliep. In de eerste fase werd volgens hem de (soortspecifieke) aminozuurketen gevormd die in de tweede fase verder werd opgevouwen tot een driedimensionaal molecuul. In de tweede fase zou het aanwezige antigeen dienst doen als een mal zó dat het antilichaam een vorm krijgt complementair aan de determinante groep van het antigeen. Voor de verklaring van de stabiliteit van de gevormde moleculen nam Pauling aan dat het centrale deel van de aminozuurketen stabiel is vanwege een bepaalde aminozuurvolgorde. Omdat uit empirisch onderzoek was gebleken dat antilichamen vermoedelijk bivalent waren, veronderstelde Pauling dat immuunglobulinen twee uiteinden hadden die na interacties met het antigeen de bindingsplaatsen verkregen en hun stabiliteit ontleenden aan onder andere waterstof bindingen. Pauling veronderstelde verder op grond van quantum-chemische overwegingen dat de polylpeptide ketens in lagen werden opgestapeld, onderling 
verbonden door waterstof bindingen. Hierdoor zou het molecuul echter te star worden om de grote diversiteit van configuraties te werklaren. Daarom postuleerde Pauling dat de polypeptide ketens veel (een derde tot de helft) proline en hydroxyproline bevatten, omdat deze de keten 180 graden konden draaien en zo voor de nodige 'flexibiliteit ${ }^{x}$ van het molecuul konden zorgen. Deze laatste gedachte bleek later onjuist: eind jaren vijftig toonde Porter aan dat de hoeveelheid proline en hydroxyproline zeer beperkt was."

Paulings speculatieve theorie was een duidelijke verbetering ten opzichte van de nogal simplistische instructietheorie van Haurowitz en anderen. Zijn theorie was preciezer, beter uitgewerkt en suggereerde een aantal nieuwe experimenten. Niettemin was Paulings model starten eindpunt van een deductieve, theoretisch-chemische benadering binnen immunochemie. Zijn theorie werd wel door anderen overgenomen maar niet door middel van deductief onderzoek verder gearticuleerd. Tot in de jaren zestig refereerde men dan ook steeds naar Paulings artikel uit 1940 wanneer er theoretische kwesties aan de orde waren. In Kuhniaanse termen betekent dit dat Paulings benadering niet als 'exemplar' heeft gefunctioneerd voor verder theoretisch onderzoek, en dus ook geen deductivistische onderzoekstraditie genereerde. Dit geldt niet alleen voor Paulings bijdrage aan de immunologie, maar ook voor zijn theoretisch-chemisch onderzoek binnen de moleculaire biologie. Met de deductieve benadering heeft Pauling zelf in 1950 de alphahelix ontdekt en vonden Watson en Crick met diezelfde deductieve benadering in 1953 de structuur van het DNA. ${ }^{10}$ In geen van deze gevallen was er echter sprake van traditievorming en een duidelijke 'exemplar' die - in Kuhniaanse zin - model stond voor op te lossen problemen. Hoogstens kan men zeggen dat Paulings benadering als quasi-exemplar functioneerde: de deductieve benadering werd wel door Watson en Crick overgenomen, maar die verschafte, behalve dat men deductief te werk moest gaan, geen concrete aanwijzingen voor de wijze waarop dat moest gebeuren. ${ }^{11}$ Een wiskundige heuristiek, die in deductieve tradities er voor zorgt dat onderzoekers op het werk wan anderen voortbouwen, ontbrak hier.

Na 1940 gingen Pauling en zijn leerlingen over op empirisch immunologisch onderzoek. Uiteraard ondernamen zij pogingen om Paulings model te testen. Een eerste, op zichzelf staande, test werd in 1942 gepubliceerd door Pauling en Campbell. ${ }^{12} \mathrm{Zij}$ probeerden in een in vitro-situatie antilichamen te vormen. Door een bepaald antilichaam onder specifieke condities te denatureren in de aanwezigheid van een hapteen, ontstond volgens hen eerst weer een ongestructureerd molecuul, waarna een gedeelte van de moleculen weer opvouwde z 6 dat zij 
een configuratie aannamen complementair aan die van het aanwezige hapteen. Dit resultaat was volgens Pauling en Campbell precies in overeenstemming met de instructietheorie van Pauling. Pogingen van anderen om dit experiment te herhalen faalden echter. ${ }^{13}$ Paulings 'claim" werd later verworpen toen bleek dat antilichamen werden gevormd uit de 'vrije' aminozuren. Het cruciale experiment werd hier verricht door moleculen radio-actief te labellen. ${ }^{14}$

Daarna publiceerden Pauling en zijn leerlingen een reeks artikelen over antigeen-antilichaam interacties, waarin zij onder andere verslag deden van hun onderzoek naar intermoleculaire krachten en de grootte van de bindingsplaats van het antilichaam. ${ }^{15}$ In hun onderzoek waren zij erin geslaagd om de rol van waterstof bindingen en Van der Waals krachten bij de antilichaam-achtigeen binding te onderscheiden, en zij toonden zelfs aan dat er een verschil in affiniteit was tussen een antilichaam en haptenen, samengesteld uit een benzeenring met een chloride atoom, en haptenen, samengesteld uit een benzeenring met een bromide atoom. Hoewel men op grond van deze studies Paulings theorie op een aantal punten kon verfijnen, was dit onderzoek in feite een voortzetting en uitbreiding van Landsteiners onderzoek. De in vitro experimenten met synthetische haptenen waren met andere woorden alle ingericht naar het model van de vroege studies van Landsteiner. Net als Landsteiner zochten Pauling c.s. de sleutel voor het probleem van de immunologische specificiteit via de chemische structuur van het antigeen. Theoretisch verklaarde Pauling de immunologische specificiteit vanuit de vormende invloed van het antigeen op de bouw van het antilichaam; in het fysisch-chemisch onderzoek onderzocht men de eigenschappen van het antilichaam en de affiniteit tussen antilichamen en antigenen door variaties aan te brengen in het antigeen. Het maatgevend voorbeeld, Landsteiners haptenen-onderzoek, structureerde daarbij de problemen en oplossingen waardoor toetsbare consequenties van Paulings theorie buiten het blikveld van de onderzoekers bleven. Die lagen - zoals later zou blijken - niet op het vlak van de fysische chemie, maar kwamen eind jaren vijftig boven tafel toen anderen de aminozuursamenstelling, aminozuursequentie en structuur van immuunglobulinen rechtstreeks gingen onderzoeken. Toen bleek dat een vooronderstelling in het onderzoek van Pauling c.s., namelijk de gedachte dat alle immuunglobulinen dezelfde aminozuursequentie hadden, onjuist was. Elk type antilichaam bleek een unieke aminozuursequentie te hebben. De resultaten van deze 'directe aanval' op de structuur van immuunglobulinen zouden uiteindelijk de genadeslag betekenen voor Paulings instructietheorie. Voor die tijd hadden biologisch georiënteer- 
de onderzoekers al gewezen op een aantal fysiologische gebreken van de instructietheorie.

\section{3}

\section{De analogie met adaptieve enzymen}

Verworven immuniteit wordt nooit 'doorgegeven' aan nakomelingen. Dit simpele gegeven laat nog eens zien dat een aanlegtheorie over immuniteit niet erg voor de hand ligt. Een omgevingstheorie, waarin wordt gesteld dat immuniteit wordt verworven doordat het organisme een antigeen 'leert' herkennen, sluit beter aan bij de 'alledaagse' ervaring. Het heeft dan ook geruime tijd geduurd voordat onderzoekers een theorie bedachten die dit simpele gegeven met een aanlegmechanisme kon verklaren. De eerste stap in die richting werd gezet door de Australische viroloog Burnet, hoewel ook zijn eerste theorie een omgevingstheorie was. Hij was de eerste biologisch georiënteerde onderzoeker die in de jaren veertig een alternatieve theorie ontwikkelde.

Cruciaal voor het onderzoek van Burnet (en later Jerne) is dat hij de immunologische problematiek vanuit een biologisch perspectief benaderde. Daardoor verschoven de problemen van het niveau van de moleculen naar hogere niveau's zoals cellen, organen, organismen, etcetera. Deze op het eerste gezicht kleine verschuiving is in feite natuurlijk een grote verandering: de chemische benadering wordt vervangen door een biologische. Zowel voor de methoden van onderzoek als voor de theorie-ontwikkeling heeft dit grote consequenties. In de chemische benadering van immunologische fenomenen probeert men door de structuur van moleculen te onderzoeken de immunologische functie van die moleculen op het spoor te komen. De structuur van moleculen, dacht Pauling, geeft uiteindelijk inzicht in de fysiologische functie. Voor deze benadering moeten chemici (idealiter) beschikken over zuivere samples, anders kan men de structuur niet onderzoeken. De biologische benadering begint aan de andere kant: een bioloog begint bij de functie van de afweer en zal pas later 'afdalen' naar de structuur van moleculen die betrokken zijn bij de afweer. Samples van zuivere stoffen zijn strikt genomen niet noodzakelijk voor het biologisch onderzoek, omdat het biologisch onderzoek op een hoger organisatieniveau begint. En samples van bijvoorbeeld cellen worden in het biologisch onderzoek voor andere doelen gebruikt dan samples van chemische stoffen. (Cellen worden niet zoals eiwitten in een 'Analyzer' gestopt om de aminozuursequentie te bepalen.) Door deze verschillen tussen de structuralistische, chemische benadering en de functionalistische, 
biologische benadering kunnen chemici en biologen onafhankelijk van elkaar immunologisch onderzoek verrichten. Toen Burnet in de jaren veertig een biologische theorie over de afweer ontwierp, deed hij dan ook geen onderzoek op het molleculair niveau. Hij ontwikkelde (deductief) een theorie over de functie van de afweer.

Burnets onderzoek begon met een kritiek op de instructietheorie. ${ }^{16}$ Het beeld dat de chemici van de immuniteit hadden gevormd was volgens hem buitengewoon simplistisch omdat men volledig voorbij ging aan biologische aspecten. Bovendien constateerde Burnet een reeks problemen waarvoor de instructietheorie geen adequate verklaring kon geven. De belangrijkste waren dat (1) de instructietheorie niet kon verklaren waardoor de tweede response op hetzelfde antigeen heftiger was dan de eerste, en (2) waarom er antilichamen werden geproduceerd in de afwezigheid van antigenen. Burnet verwierp dan ook de instructietheorie en ontwikkelde (samen met Fenner) een alternatief naar analogie met de vorming van adaptieve enzymen. 17

Uitgangspunt in deze theorie was de overlevingswaarde van het immunologisch reactievermogen. Een theorie over dit reactievermogen diende volgens Burnet in ieder geval twee belangrijke kenmerken ervan te verklaren. Ten eerste het simpele gegeven dat organismen antilichamen produceren tegen 'niet-eigen' maar niet tegen 'eigen' stoffen. De overlevingswaarde van het kunnen onderscheiden van 'eigen' en 'nieteigen' was volgens Burnet snel in te zien, maar daarmee was nog niet verklaard hoe dit onderscheid (in de ontogenie) ontstond. Ten tweede moest de theorie verklaren waardoor eenmaal verworven immuniteit zeer lang werkzaam blijft. Ook hier is duidelijk dat dit voordelig is; een verklaring is echter nog niet gegeven. Verklaringen van deze kenmerken moesten volgens Burnet recht doen aan de rol van cellen die betrokken zijn bij de afweer, omdat daarmee het permanente karakter van het reactievermogen kon worden geduid. Burnet ontwikkelde zijn theorie naar analogie met de toendertijd gangbare visie op de vorming van adaptieve enzymen. De reden voor juist deze analogie was niet zo vreemd: wanneer bacteriën in een medium worden gebracht met bijvoorbeeld een suiker die zij niet kunnen verteren, dan kunnen die bacteriën na verloop van tijd een 'vermogen' ontwikkelen om die suiker te verteren. Dat ontstaan van een vermogen werd toegeschreven aan de ontwikkeling van adaptieve enzymen. Voor Burnet was van belang dat in dit proces een stimulus uit de omgeving een permanente (of semipermanente) verandering in het reactievermogen van een cel teweeg bracht. Naar analogie veronderstelde Burnet nu dat antigenen de ontwikkeling van adaptieve enzymen stimuleerden die noodzakelijk waren voor de synthese van globulinen. Afhankelijk van de aard van de anti- 
gene stimulus zou zo een zelfreplicerende cenheid in de cel ontstaan die antilichamen produceert. Die eenheid was volgens Burnet een modificatie van een al aanwezig enzymsysteem waarmee organismen onder andere beschadigde cellen opruimen.

Deze theorie, die door Burnet later werd gearticuleerd en in 1955 door Talmage ${ }^{18}$ de 'indirect template theory' werd genoemd ter onderscheiding van de 'direct template theory' van Haurowitz en Pauling, had een belangrijke consequentie. Die had betrekking op de wijze waarop Burnet het tot stand komen verklaarde van het onderscheid tussen 'eigen' en 'niet-eigen'. Burnet werkte zijn theorie deductief uit aan de hand van het chimerenonderzoek van Owen dat in 1945 was gepubliceerd. ${ }^{19}$ Chimeren zijn tweeëiige foetussen die een gemeenschappelijke placenta hebben waardoor de bloedbanen van die foetusssen met elkaar zijn verbonden. Owen had ontdekt dat runderen, opgegroeid als chimeren, twee typen rode bloedcellen bezitten: de eigen bloedcellen en die van de andere helft van de tweeling. Dit was een opmerkelijk gegeven omdat runderen normaliter bepaalde typen bloedgroepen niet accepteren en er antilichamen tegen vormen. Het belang van deze observatie lag volgens Owen op het terrein van de genetica, de ontogenie en de immunologie, maar een systematische verklaring gaf hij niet. Burnet gebruikte Owens ontdekking om zijn theorie verder te articuleren. Hij veronderstelde dat tijdens de ontwikkeling het vermogen om een onderscheid te kunnen maken tussen 'eigen' en 'niet-eigen' ontstond. Cellen die tot het organisme behoorden droegen volgens hem 'self-markers' en zouden in een vroege fase van de ontwikkeling, d.w.z. in een fase waarin het organisme nog geen antilichamen produceert, als 'eigen' worden herkend door een enzymsysteem. Wanneer nu foetussen in een vroege fase van de ontwikkeling in contact komen met 'vreemde' cellen, zullen zij die ook als 'eigen' gaan herkennen. Hieruit leidde Burnet een direct toetsbare consequentic af: 'if, in embryonic life, expendable cells from a genetically distinct race are implanted and established, no antibody response should develop against the foreign cell antigen when the animal takes independent existence, ${ }^{20}$ Deze theoric was om twee redenen belangrijk.

In de eerste plaats had Burnet een algemeen theoretisch principe geconstrueerd waarmee 'geìsoleerde toevalsontdekkingen' van andere onderzoekers onder een noemer konden worden gebracht. Medawar 'ontdekte' het verschijnsel immuuntolerantic in 1948 , toen hem werd gevraagd hoe monozygotische en dizygotische tweelingen van runderen eenduidig zijn te onderscheiden. ${ }^{21}$ Uit zijn transplantatie-onderzoek wist Medawar dat individuen nooit huidtransplantaten van een genetisch verschillende donor accepteerden, en stelde daarom een eenvou- 
dige transplantatietest woor. Deze test, die Medawar en Billingham uitvoerden, leverde als omwerwacht resultaat dat alle tweelingen de huidtransplantaten van de andere helft van de tweeling accepteerden, ook bij verschillende seksen. Nadat Medawar c.s. het werk wan Burnet (en Owen) hadden bestudeerd, realiseerden zij zich dat de onderzochte runderen waren opgegroeid als chimeren. Een ander, curieus voorbeeld is het onderzoek van de Tsjecho-Slowaak Hasek, dat zelfs door de 'verkeerde' ideeën was geïnspireerd. Uitgaande van de Lysenko-doctrine wilde Hasek aantonen dat de mendeliaanse overerving van bloedgroepen te beinvloeden was door omgevingsfactoren. Daarvoor verbond hij de bloedbanen van twee kippenembryo's en vond dat deze embryo's later elkaars bloedcellen accepteerden! Na discussies met Medawar, zo gaat de overlevering, verliet Hasek de Lysenko-doctrine. ${ }^{22}$

In de tweede plaats was de experimenteel toetsbare consequentie die Burnet uit zijn theorie had afgeleid van groot belang voor verder onderzoek naar het verschijnsel immuuntolerantie. Hoewel een poging van Burnet faalde, bevestigden Billingham, Brent en Medawar Burnets voorspelling door aan te tonen dat immuntolerantie kunstmatig kon worden opgewekt. ${ }^{23}$ Daarvoor introduceerden zij bij foetussen van muizen in utero donorcellen van een genetisch verschillende stam. $\mathrm{Na}$ deze behandeling accepteerden de dieren de huidtransplantaten van de donor en herkenden de transplantaten dus als 'eigen'.

Dit bekende transplantatie-experiment van Medawar c.s. was het eerste grote succes van de alternatieve, biologische theorie over immuniteit. Niettemin was het een van weinig ontdekkingen die werd voorspeld door Burnets theorie. De biologische ontdekkingen die erop volgden bleven vaak een toevalskarakter houden en werden zeker niet voorspeld door de theorie van Burnet. Voorbeelden zijn de 'graft-versus-host' response door Billingham, Brent en Simonsen; de ontdekking van Gowans dat lymfocyten net als rode bloedcellen circuleren in het lichaam; de ontdekking van Miller en Good dat de thymus een rol speelt bij het uitrijpen van de lymfocyten; en de ontdekking van Glick, Chang en Jaap dat de bursa van Fabricius bij kippen een rol speelt bij het uitrijpen van lymfocyten. Stuk voor stuk ontdekkingen die inzicht zouden geven in de fysiologische mechanismen die betrokken zijn bij immunologische reacties, maar in eerste instantie ongeinterpreteerde feiten bleven. 


\section{Natuurlijke en klonale selectie}

In de periode 1948-1956 probeerde Burnet de analogie met adaptieve enzymen verder uit te werken, wat resulteerde in de publicatie Enzyme, Antigen and Vinus. ${ }^{24}$ Al wớrdat het boek verscheen groeide Burnets onvrede over zijn eigen theorie en na de publicatie van Jerne's natuurlijke selectietheorie zou hij deze theorie snel terzijde schuiven.

Jerne's natuurlijke selectietheorie was het startpunt van een radicale transformatie van de immunologische theorievorming: de omgevingstheorie verving hij door een aanlegtheorie. Jerne's benadering van immunologische problemen was net als bij Burnet deductief. Niettemin was er wel een opvallend verschil tussen hun benaderingswijzen. Het deductieve element in het theoretisch onderzoek van Burnet lag vooral in de ontwikkeling van ideeën. 'I have had and still have much enjoyment from playing with ideas', schreef Burnet in zijn artikel 'The impact of ideas on immunology'. ${ }^{25}$ In dit artikel uit 1967 constateert hij dat de chemische traditie binnen de immunologie: 'has been strikingly little influenced by preconceived ideas:. ${ }^{26}$ Volgens Burnet was deze empirisch-chemische aanpak weinig vruchtbaar. 'I believe that scholarly work in science must aim at generalization and that research lacks meaning if it is not at every stage guided and stimulated by hypotheses, including major ones, devised on the best available data and analogies and put in such form that in principle and experimental discussion, proof, disproof or modificiation, should be eventually possible'. ${ }^{27}$ Deze typisch Popperiaanse houding vinden we ook terug in zijn visie op kennis: 'may I remind you that scientific truth can be defined as that corpus of facts and provisional generalizations which, in the consensus of competent scholars, has not yet been shown to be wrong'.

Het deductieve element in Jerne's benadering lag, naast de nadruk op het belang van ideeën, ook in het gebruik wan wiskunde. In dit opzicht komt zijn benaderingswijze overeen met die van de 'tweede generatie' moleculaire biologen, zoals Watson en Crick. Fysici als Delbrück, die tot de 'eerste generatie' behoorden, stelden zich tot doel met behulp van wiskundige methoden nieuwe wetten in de biologie te ontdekken. ${ }^{29}$ Achteraf kunnen we constateren dat deze strategie niet erg succesvol is geweest: er is geen enkele nieuwe wet gevonden. De ontdekkingen binnen de moleculaire biologie kunnen voor een groot deel op het conto worden geschreven van de tweede generatie en bestonden uit het toepassen wan al bekende principes uit de fysica en chemie op probleemsituaties in de biologie. Weliswaar waren ook zij vaak opgeleid tot fysicus, maar de wiskundige benadering gebruikten zij niet om nieuwe 
wetten te vinden, maar als heuristiek voor het inperken van theoretische variaties. Deze aanpak was ook karakteristiek voor het immunologisch onderzoek van Niels Jerne. Hij was (in Leiden) opgeleid tot fysicus, onderhield in de beginfase van zijn onderzoek contacten met Niels Bohr en Max Delbrück, en werkte in de periode 1950-1951 samen met onder andere James Watson en Günther Stent in Kopenhagen. Hij bevond zich in de periferie van het faagnetwerk. De wiskundige benadering bestond in zijn geval voornamelijk in het gebruik van wiskunde en statistiek voor het uitvoeren van berekeningen in de immunologie. Jerne omschreef zijn werkwijze later als volgt:

'In my approach to immunollogy, I think I regarded the immune system (like everybody else did) as a machine, but the machine I thought of had something to do with roulette. I was always surprised at the enormous differences in the response to the same amount of antigen between individuals of the same strain, age, conditions, etc. These differences we used to register as distributions for which you might calculate the type of distribution, its variance, standard deviation, etc., based on the laws of probability. Furthermore, I had studied physics (in Leiden) and had noticed that physicists work with numbers of the order of $10^{24}$ in subjects such as thermodynamics. In ordinary life, we usually deal with numbers smaller than 1.000, and I found (and find) that one of the difficulties of biology is that the numbers which interest us (number of cells, number of antibody molecules, etc.) are somewhat awkward in that they are neither small nor as large as those that permit physicists to derive laws of nature'. ${ }^{30}$

Twee voorbeelden kunnen deze werkwijze verder verduidelijken. In zijn dissertatie liet Jerne zien dat het door chemici gebruikte begrip 'affiniteil' (de affiniteit tussen antigeen en antilichaam) te beperkt was. ${ }^{31}$ Hij berekende dat de 'aviditeit' tussen antilichamen en antigenen in de loop van een immunisatie programma steeds beter werd. Dit resulltaat was in strijd met de chemische interpretatie van de affiniteit omdat de instructietheoretische interpretatie veeleer een sleutel-slot mechanisme suggereerde dat niet verbeterd kon worden (vergelijk ook hoofdstuk 4, par. 4.6) Een tweede voorbeeld is het onderzoek dat Jerne deed naar de hoeveelheid verschillende antilichamen in het serum van dieren. Op grond van verschillen tussen geïmmuniseerde en niet-geïmmuniseerde dieren berekende Jerne dat het serum van een dier circa $10^{7}$ verschillende antilichamen moest bevatten. ${ }^{32}$ Hoewel dit soort berekeningen natuurlijk niet een aanlegtheorie over immuniteit sugge- 
reerden, legden zij wel duidelijke restricties op aan theoretische mogelijkheden. In die zin droeg de wiskundige benadering bij aan de ontwikkeling van een alternatieve theorie.

De noodzaak om een alternatieve theorie te ontwikkelen werd, net als bij Burnet, ingegeven door het feit dat de instructietheorie werd geplaagd door een reeks anomalieën. Jerne legde vooral de nadruk op het empirisch gegeven dat veel antilichamen worden geproduceerd zonder een antigene stimulus. In de definitie van een antilichaam werd volgens Jerne wel gesuggereerd dat antilichamen substanties zijn die in response op een antigene stimulus worden geproduceerd, maar zo'n definitie impliceert niet dat dit ook daadwerkelijk het geval is. In zijn selectietheorie keerde Jerne de zaak volledig om. ${ }^{33}$ Organismen beschikken volgens deze theorie over een breed scalla aan natuurlijke antilichamen die worden gegenereerd door een random proces. De rol van het antigeen was volgens Jerne niet die van een mal, zoals in de instructietheorie werd gesteld, noch die van een modificator van een enzymsysteem, zoals Burnet dacht. Antilichamen worden volgen hem continu geproduceerd, onathankelijk van thet antigeen, in een enorme variëteit van verschillende configuraties. Te midden van die grote hoeveelheid verschillende antilichamen zal zich een antilichaam bevinden dat met een binnen gedrongen antigeen kan binden omdat het molecuul 'toevallig' een complementaire bindingsplaats heeft. Het zo gevormde antilichaam-antigeen complex zal volgens Jerne worden opgenomen door fagocyterende cellen die vervolgens antilichamen gaan produceren van het zojuist opgenomen type.

Jerne ontwikkelde zijn theorie in Kopenhagen en werkte de theorie verder uit in Pasadena bij Delbrück. Erg vruchtbaar was het verblijf in Pasadena niet, want Delbrück, Pauling en Watson zagen niet veel in zijn natuurlijke selectietheorie. ${ }^{34}$ Burnet dacht daar in Melbourne geheel anders over. Het voordeel van Jerne's theorie was volgens hem dat de theorie een aantal fenomenen op een eenvoudiger wijze verklaarde. Het verschil tussen de primaire en secondaire response bijvoorbeeld, werd volgens Jerne veroorzaakt doordat antigenen bij een tweede contact in aanraking komen met een hogere concentratie specifieke antilichamen die bij het eerste contact waren geproduceerd. Immuuntolerantie, oftewel het onvermogen om tegen lichaamseigen elementen antilichamen te maken, verklaarde Jerne door aan te nemen dat de antilichamen tegen lichaamseigen antigenen tijdens de ontogenie werden geëlimineerd. Ondanks deze voordelen maakte Burnet bezwaar tegen Jerne's idee dat het antilichaam-antigeen complex fagocyterende cellen aanzet tot het maken van replica's van antilichamen. De oorsprong van de diversiteit van de antilichamen bleef zo onverklaard zodat de theorie 
van Jerne op dit punt moest worden veranderd. Tegelijkertijd, maar onafhankelijk van elkaar, ontwikkelden Burnet en Talmage in 1957 een alternatief, dat door Burnet uitwoerig werd uitgewerkt. ${ }^{35}$

Het uitgangspunt lag dit keer bij de populatiedymamica, waarvan Burnet het model toepaste op de cellen in het lichaam. Hij postuleerde dat de replicerende elementen, die de antilichamen maken, $a b$ initio cellen waren. Organismen beschikken over een populatie cellen waarvan elke cel een bepaald type antilichaam produceert. De cellen zouden wolgens Burnet bovendien een antilichaam op de buitenkant van de celwand hebben, identiek aan het antilichaam dat zij produceren. Wanneer nu een antigeen het lichaam binnendringt en uit de populatie cellen een cel 'selecteert' waarmee het antigeen kan binden, dan zou die cel worden geactiveerd tot deling waardoor die cel in de populatie toeneemt en daarmee het type antilichaam dat door de cel wordt geproduceerd. Het antigeen fungeerde dus volgens Burnets theorie niet als stimulus, maar als trigger voor de productie van antilichamen. Deze trigger zette volgens Burnet een deel van de cellen uit de populatie aan tot proliferatie, terwijl een ander deel van de cellen werd 'getransformeerd' tot geheugencellen die bij de tweede response voor de heftiger reactie zorgden.

Deze theorie werd door Burnet gedoopt tot klonale selectietheorie. Net als bij zijn eerste theorie had deze theorie een direct toetsbare consequentie: de theorie voorspelde dat én cel één antilichaam produceerde. Een ingenieus experiment, waarin deze voorspelling werd getest, werd bedacht door de geneticus Joshua Lederberg.

Lederberg was in 1957 naar Melbourne gekomen om tijdelijk samen met Burnet aan de genetica van influenza virussen te gaan werken. $\mathrm{Na}$ discussies over de pas 'geboren' klonale selectietheorie werden die plannen in de ijskast gestopt. ${ }^{36}$ Lederberg, die ervaring had met het isoleren van cellen, suggereerde dat de klonalle selectietheorie kon worden getoetst door eerst dieren te immuniseren met twee verschillende typen antigenen en daarna geïsoleerde cellen te testen op hun vermogens om antilichamen te produceren. Als de klonale selectietheorie hout sneed, dan zou een cel een antilichaam moeten produceren tegen eén van de twee antigenen maar nooit tegen beide. Dit experiment werd uitgevoerd door Nossal, een leerling van Burnet. Hij nam als antigenen de (geëxtraheerde) eiwitten van de flagellen van twee typen Salmonella bacteriën: Salmonella adelaide en Salmonella typhi. $\mathrm{Na}$ immunisatie met deze antigenen nam hij cellen uit de lympheklieren (van ratten) die hij vervolgens na een speciale behandeling in een "oliekamertje" bracht. Zo'n oliekamertje bestond uit de geïsoleerde cel in een druppel weefsellcultuur vloeist of op een glasplaatje. Deze druppel 
werd afgedekt met een dunne laag paraffine-olie, zodat de vloeistof niet verdampte. Onder een microscoop werden daarna een aantal van én van de twee typen Salmonella bacteriën met een micromanipulator bij de cel gevoegd. Als criterium voor de produktie van antilichamen nam Nossal de beweeglijkheid van de Salmonella bacteriën, aangezien de antilichamen tegen de eiwitten van de flagellen de flagellen paralyseerden. De tellingen van de beweeglijkheid van de Salmonella bacteriên bevestigden het vermoeden van Lederberg: geïsoleerde cellen produceerden een antilichaam tegen één van de twee typen Salmonella's, maar nooit tegen beide. ${ }^{37}$

Deze vroege bevestiging van de klonale selectietheorie zou niettemin vlak daarna in twijfel worden getrokken. Pogingen om het experiment van Lederberg en Nossal te herhalen leverden in eerste instantie tegenstrijdige resultaten op: Attardi, Hiramoto, Hamlin en anderen vonden dat én cel wel twee antilichamen kan produceren. Deze tegenstrijdigheden waren uiteraard aanleiding tot onderzoek naar de gebruikte technieken en methodieken die bij de 'single cell'-studies nogal ingewikkeld waren. Pas in 1967 zou het pleit definitief worden beslecht ten voordele van de klonale selectietheorie. Mäkelä concludeerde toen dat de 'dissidente' resultaten het gevolg waren van onzorgvuldigheden bij de het prepareren van samples. ${ }^{38}$ Dergelijke geschillen zouden door de introductie van nieuwe technieken in de loop van de jaren zestig afnemen en na 1975 zelfs geheel verdwijnen. Jerne en Nordin brachten in 1965 een sterke vereenvoudiging aan door de (veel oudere) plaque techniek operationeel te maken voor het immunologisch onderzoek. Met deze techniek werd het weel gemakkelijker om het gedrag van geïsoleerde cellen te bestuderen. Een ander voorbeeld is de 'technologische revolutie', teweeggebracht door de ontwikkeling van monoklonale antilichamen door Köhler en Milstein in 1975. Met deze techniek kan men onsterfelijke kJonen maken van cellen die één type antilichaam produceren door een B-lympfocyt te laten fuseren met een kankercel uit het beenmerg. Met de techniek van Milstein en Köhler kan men, zoals Roitt opmerkt, "a single standard material for all laboratories throughout the world ${ }^{39}$ ontwikkelen. Monoklonale antilichamen zijn met andere woorden experimenteel gecreëerde samples. De techniek is in feite de uitkomst van theoretisch onderzoek omdat het achterliggende idee terug gaat op de klonale selectietheorie van Burnet. Burnets theorie voorspelde dat eén cel éen antilichaam produceert, Lederberg en Nossal bevestigden dit idee, en later bouwden Milstein en Köhler dit idee om tot een techniek. Discussies over 'single cell'studies konden daarmee uit de handboeken worden geschrapt. 
Het bezoek van Lederberg aan Melbourne resulteerde, naast het belangwekkende 'single cell'-experiment, nog in een tweede bijdrage aan inmunologie. In 1959 publiceerde hij een theoretisch artikel over de genetische grondslagen van de klonale selectietheorie. ${ }^{40}$ Centraal stond de gedachte dat de stereospecifieke structuur van de immuunglobulinen werd bepaald door de aminozuursequentie van de peptideketens, die op haar beurt genetisch werd gereguleerd. Gezien de grote diversiteit van antilichamen was volgens Lederberg echter nog een extra mechanisme nodig om die grote diversiteit te verklaren. Hij postuleerde dat de diversiteit ontstond door mutaties tijdens de ontwikkeling van somatische cellen. Toekonstig onderzoek naar de structuur van immuunglobulinen moest volgens hem deze kwestie verder ophelderen.

\section{5}

\section{Immunochemie en genetica}

Door de verschillen tussen de structuralistische en de functionalistische benadering werkten chemici en biomedici lange tijd langs elkaar heen. Deze benaderingen van immunologische vraagstukken waren niet alleen bepalend voor de wijze waarop ideeën werden ontwikkeld, maar structureerden ook het denkverkeer tussen de chemische en biologische traditie. In de jaren vijftig en zestig ontstonden controversen tussen vertegenwoordigers van beide tradities. Chemici verdedigden in eerste instantie de instructietheorie tegenover de theorieën van Burnet en Jerne. Hun argumenten maakten echter weinig indruk op de biologen. Dat organismen antilichamen kunnen vormen tegen duizenden synthetische stoffen, 'did not seem to worry too much the biologically minded immunologists who were more interested in the pathogenic bacteria and viruses than in chemically defined haptens, ${ }^{4}$ Omgekeerd lieten de chemici zich niet overtuigen door de theoretische argumenten van de biologen. Gezien het verschil in benaderingswijze (structuralistisch versus functionalistisch) en, daarmee verbonden, het verschil in niveau (moleculair versus cellulair en hoger), is dit niet opzienbarend. Deze globale tegenstelling vinden we terug in de discussies over de kritiek van met name Burnet op de instructietheorie. De biologische kritiek die Burnet tegen de instructietheorie had aangevoerd werd door chemici binnen het kader van de instructietheorie aangepast. ${ }^{42}$ Op de kritiek waarom organismen antilichamen in de afwezigheid van antigenen produceren, antwoordde Haurowitz dat de huidige technieken misschien niet voldoende gevoelig waren om de antigenen te lokaliseren. Toekomstig onderzoek zou kunnen uitwijzen dat ze wel aanwezig wa- 
ren. Op de vraag waardoor de tweede response heftiger verloopt dan de eerste, antwoordden instructietheoretici dat cellen na het eerste contact misschien beter werden in het 'vangen' van hetzelfde antigeen. De vraag, hoe met de instructietheorie kon worden verklaard waarom organismen geen antilichamen tegen lichaamseigen elementen produceren, beantwoordde Haurowitz op soortgelijke wijze: 'it is conceivable that we produce such antibodies continually, but that we are not able to detect them because they are neutralized by the continuous production of an excess of serum albumin and the other serum proteins, ${ }^{43}$

Uit het feit dat de instructietheorie door louter aanpassingen werd gered, zou men kunnen opmaken dat de instructietheorie danig in een slop was geraakt. In de jaren vijftig boekten studies naar de aminozuursamenstelling en aminozuursequentie van antilichamen echter nog empirische successen die de instructietheorie leken te bevestigen. Voorbeelden zijn de studies van Smith c.s. en Fleischer c.s. die respectievelijk in 1955 en 1961 werden gepubliceerd. ${ }^{44} \mathrm{Zij}$ vergeleken de aminozuursamenstelling van immuunglobulinen tegen verschillende antigenen en vonden geen grote verschillen in de aminozuursamenstelling. Deze gegevens suggereerden volgens hen dat de verschillende antilichamen niet alleen dezelfde aminozuursamenstelling hadden, maar vermoedelijk ook dezelfde aminozuursequentie, wat in overeenstemming was met Paulings model. Een ander voorbeeld is het vroegere werk van Porter naar de bouw van immuunglobulinen in de periode 1950-1960. Met het enzym papaine kon Porter immuunglobuline-moleculen in drie delen splitsen. Twee delen bleken na splitsing nog te kunnen binden met antigenen terwijl het derde deel, dat niet kon binden met antigenen, te kristalliseren was. Deze gegevens suggereerden dat het derde deel in alle immunglobulinen identiek was en dat de twee andere delen de bindingsplaats voor de antigenen bevatten, hetgeen - volgens Porter - in overeenstemming was met Paulings model. Bovendien toonde Porter aan dat een klein gedeelte van de antigeen-bindende delen tegen verschillende antigenen dezelfde aminozuursequentie had. Hoewel Paulings instructietheorie voor fysiologische problemen stond, aangedragen door Burnet, waren er kortom goede redenen om de instructietheorie te blijven verdedigen. De conclusie die Porter in 1959 trok is illustratief: 'final conclusions as to the validity of this and other theories of antibody formation must await more detailed work, but it is clear that the chemical evidence described here, contrary to the physiological evidence in the introduction, is in accordance with Pauling's theory'. ${ }^{45}$

Na de opkomst van de aanlegtheorieën van Jerne en Burnet zou het tij keren. Koshland en Englberger herhaalden toen met verfijndere technieken en zuiverder samples de studies van Smith c.s. en Fleischer 
c:S.;.; zij vonden wal subtiele verschillen in de aminozuursamenstelling van verschillende antilichamen. ${ }^{46}$ Vanuit een aanlegperspectief werden kleine verschillen in de aminozuursamenstelling wan antilichamen relevant. Voor instructietheoretici, die verwachtten dat alle antilichamen dezelfde aminozuursamenstelling hadden, waren de gevonden 'afwijkingen" ruis. Voor aanlegtheoretici, die juist kleine verschillen verwachtten, werden die geringe afwijkingen betekenisvol. Verder onderzock naar de aminozuursequentie bracht aan het licht dat sommige delen van de immunglobulinen variabe] waren: de aminozuursequentie verschilde van molecuul tot molecuul. Haber, Tanford en Whitney lieten zien dat immuunglobulinen, nadat ze eerst gedenatureerd waren door verbreking van de disulfide bruggen, spontaan weer opvouwden tot een immuunglobuline-molecuul en voor een groot deel de bindingsmogelijkheden met een antigeen behielden. ${ }^{47}$ Resultaten die alle in strijd waren met de instructietheorie, maar geïncorporeerd konden worden in de aanlegtheorie die na 1955 tot bloei was gekomen.

Deze voorbeelden waren symptomatisch voor de veranderende relatie tussen de biologische en de chemische traditie binnen de immunologie. Steeds vaker werden onderzoeksresultaten, verkregen in structuralistisch onderzoek, geinterpreteerd in termen van de darwinistische sellectietheorie. Twee ontwikkelingen waren hierbij van cruciaal belang. Ten eerste de theoretische ontwikkelingen binnen de zogenaamde informatietraditie in de biochemie. Deze stelden immunologen in staat de klonale selectietheorie in moleculair-genetische termen verder te articuleren, waardoor de resultaten van het chemisch onderzoek darwinistisch konden worden geïnterpreteerd. Ten tweede de experimentele ontwikkelingen binnen de biochemie die chemici in staat stelden de structuur van antilichamen 'direct' te onderzoeken. Beide ontwikkelingen werden ingeluid door het onderzoek van Sanger en zijn medewerkers naar de aminozuursequentie van het relatief kleine eiwit insuline. Door dit eiwit met behulp van verschillende enzymen te 'knippen' konden zij eind jaren veertig fragmenten van het insulinehormoon isoleren met steeds verschillende aminozuursamenstellingen. Zo verkregen zij honderden fragmenten waaruit zij de gehele aminozuursequentie van het eiwit konden reconstrueren. Sanger heeft deze werkwijze vergeleken met de manier waarop men uit auto-onderdelen een complete auto reconstrueert. Soms vindt men een as met daaraan een wiel, wat suggereert dat beide onderdelen ook in de intacte auto zijn verbonden. Op analoge wijze slaagden Sanger c.s. erin de aminozuurvolgorde van het insuline-hormoon te bepalen uit de fragmenten die uit twee of drie aminozuren be stonden. 
Dit onderzoek van Sanger was om twee redenen belangrijk. In de eerste plaats voor theoretische ontwikkelingen binnen de moleculaire biologie. Uit het onderzoek van Sanger bleek dat de volgorde van de aminozuren in het insuline-hormoon geen biochemische regelmaat vertoonde: er was geen patroon in te herkennen dat met fysische of chemische principes kon worden verklaard. De 'informatie' die het molecuul bevatte moest dan ook via andere wegen worden geinterpreteerd. Binnen de moleculaire biologie zou dit probleem uiteindelijk worden verklaard met behulp van de genetische code. In de tussentijd had Crick al met het centrale dogma de link tussen de genetica en de aminozuursequentie van eiwitten gelegd. Uitgaande van functionalistische en theoretisch-chemische overwegingen ontwikkelde hij deductief zijn dogma waarbij de resultaten van het onderzoek van Sanger als toetsstenen werden gebruikt. Volgens Cricks dogma wordt informatie alleen doorgegeven van het DNA via het RNA naar de eiwitten, maar nooit van eiwitten naar eiwitten (of RNA), waaruit volgt dat de aminozuursequentie van eiwitten genetisch is vastgelegd. De verschillen die Sanger had gevonden tussen de verschillende (soortspecifieke) aminozuursequenties van insuline-hormonen, waren gelokaliseerd op bepaalde segmenten van de ketens en konden volgens Crick evolutionair worden geïnterpreteerd en verder worden onderzocht door eiwit-taxonomisch onderzoek. De resultaten van het structuralistisch onderzoek werden, met andere woorden, binnen een evolutionair kader geïnterpreteerd. Daarmee had Crick een relatie gelegd tussen het structuralistisch en functionalistisch onderzoek. Crick maakte in zijn artikel uit 1957 echter een uitzondering voor relatief grote moleculen als immuunglobulinen: daarvoor zou het centrale dogma mogelijk niet opgaan. ${ }^{48}$

Het onderzoek van Sanger was in de tweede plaats belangrijk als maatgevend voorbeeld voor studies naar andere eiwitten. In principe was het nu mogelijk om ook van andere eiwitten de aminozuursequentie te bepalen. Bij de toepassing van Sangers methode op immuunglobulinen stond men voor drie problemen. Ten eerste het - overkomelijk probleem dat immuunglobulinen circa 25 maal zo groot zijn dan het insuline-hormoon, waardoor de ontrafeling van de aminozuurvolgorde sowieso werk van lange adem is. Ten tweede het probleem dat men, voordat de aminozuursequentie kan worden bepaald, eerst het molecuul moet afbreken tot polypeptideketens. De grote stap vooruit werd in 1959 door Edelman gezet, toen hij ontdekte dat immuunglobulinen bestaan uit lichte en zware ketens die zijn verbonden door disulfide bruggen. ${ }^{49}$ Maar het derde en lastigste probleem bleef lange tijd dat immuunglobulinen van éen individu een grote diversiteit vertonen. De traditionele aanpak bood weinig soelaas voor de isolatie van zuivere 
samples van een type antilichaam. Antilichamen kunnen worden verkregen via precipitatie door eerst dieren met een bepaald antigeen te

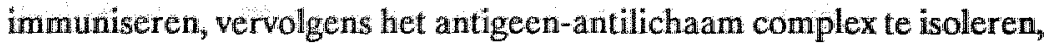
en daarna mett een zwak zuur te scheiden. Met deze methode krijgt men echter geen zuivere samples van een bepaald type immuunglobuline aangezien antigenen verscheidene antigene determinanten bezitten zodat men na precipitatie altijd een mengsel van verschillende immuunglobulinen overhoudt. Begin jaren zestig ontdekte Edelman een alternatieve methode.

In 1847 had de arts Henry Bence Jones een artikel geschreven over een substantie in de urine van patienten met Mollitius Ossium (wat nu wordt genoemd: multiple myeloma). Later werd die substantie (Bence Jones-eiwitten genoemd) geanalyseerd en lange tijd alleen in de medische praktijk gebruikt bij de diagnose van deze ziekte, een kanker van plasma cellen. Typisch voor de ziekte is een woekering van de plasma cellen met als gevolg een enorme produktie van antilichamen. Begin jaren zestig opperde Edelman het vermoeden dat de Bence Jones-eiwitten de lichte ketens van de immuunglobulinen waren die - om de een of andere oorzaak - niet in een molecuul werden geïncorporeerd. Vergelijkend onderzoek van Edelman en Gally bevestigde dit vermoeden: zij lieten in 1962 zien dat het gedrag van de Bence Jones-eiwitten en lichte ketens niet of nauwelijks verschilde bij een aantal chemische testen en ook de aminozuursamenstelling verschilde niet. ${ }^{50}$ Dit resultaat was van cruciaal belang voor het onderzoek naar de aminozuursequentie van immunglobulinen. Omdat de lichte ketens die door de myeloma tumoren werden geproduceerd identiek waren en in grote hoeveelheden werden gevormd, kon men nu zonder al te grote problemen zuivere samples verkrijgen van die lichte ketens en de aminozuursequentie onderzoeken. De ontdekking van Edelman werd - zoals Jerne later opmerkte - gevolgd door 'a burst of structural analysis in many laboratories. ${ }^{51}$ In relatief korte tijd slaagde men erin de complete aminozuursequentie van immuunglobulinen te bepalen. Eerst werd de aminozuurvolgorde van de Bence Jones-eiwitten ontrafeld, en daarna van het complete molecuul. Voor de bepaling van de aminozuurvolgorde van immuunglobulinen gebruikte men samples uit bloed van myeloma-patiënten. Vergelijkend onderzoek wees uit dat de lichte (en zware) ketens waren opgebouwd uit constante, dat wil zeggen in ieder molecuul dezelfde, delen en variabele delen. De aminozuursequentie in de variabele delen verschilde van molecuul tot molecuul.

De ontdekking van de variabele delen was een verdere bevestiging van de gedachte dat de bouw van antilichamen werd bepaald door de aminozuurvolgorde van de lichte en zware ketens. De verschillende 
configuraties van de immuunglobulinen konden nu worden verklatard uit de variaties in de aminozurursequentie waardoor een instructiemechanisme geheel overbodig werd. Daarmee was het belangrijkste bezwaar dat Haurowitz en anderen tegen een aanlegtheorie hadden in feite ontkracht.

Nadat de aminozuursequentie van de immuunglobulinen was ontrafeld, was de weg vrij gemaakt voor een genetische verklaring van de heterogeniteit van de immuunglobulinen. Dit probleem bleek echter al snel lastiger dan men op grond van moleculair-genetisch bekende mechanismen zou vermoeden. In dit verband kan alleen een ruwe schets worden gegeven van de problematiek. Onderzoek naar de structuur van immuunglobulinen met behulp van monoklonale antilichamen leverde in de loop van de jaren zeventig en tachtig het volgende beeld: immuunglobulinen bestaan uit vier polypeptideketens die zijn verbonden door disulfide bruggen (en noncovalente bindingen). De vier polypeptideketens zijn onder te verdelen in twee identieke lichte ketens van circa 220 aminozuren en twee identieke zware ketens van 330 of 440 aminozuren. De ketens vormen te samen een $\mathrm{Y}$-vorm. De armen van de $\mathrm{Y}$ bevatten de variabele delen van zowel de lichte als de zware ketens. Binnen de variabele delen bevinden zich weer zogenaamde hypervariabele segmenten die zich aan de uiteinden van de armen bevinden en de bindingsplaatsen voor de antigenen vormen. Voor de genetische verklaring van de structuur van immuunglobulinen zijn verschillende theorieën ontworpen, die op een centraal punt uiteen liepen. ${ }^{52}$ In de 'preformationistische' (of fylogenetische) varianten stelt men dat de diversiteit van de immuunglobulinen genetisch is vastgelegd en al aanwezig is in de geslachtscellen. Voor elke polypeptide is er een gen. Problematisch voor deze theorie is dat zij een gigantische hoeveelheid genen moet veronderstellen. In de tweede, 'epigenetische' of (ontogenetische) varianten gaat men uit van een beperkt aantal structurele genen in de geslachtscellen en veronderstelt men dat de diversiteit ontstaat door recombinaties en mutaties tijdens de ontogenie in de somatische cellen. Empirische bewijzen voor de 'epigenetische' varianten zijn vrij recent gegeven: gebleken is dat herschikkingen en mutaties inderdaad voorkomen. In 1987 kreeg Tonegawa de Nobelprijs voor zijn onderzoek naar de genetische mechanismen achter de antilichaamdiversiteit en met zijn verklaringen behoort de zogenaamde paradox van de antilichaamdiversiteit tot het verleden. ${ }^{53}$ 


\section{6}

\section{Conclusies}

De immunologie is in de loop van dertig jaar getransformeerd van een chemische traditie in een biomedische traditie. De wetenschap van 'eigen' en 'niet-eligen', zoals de immunologie tegenwoordig wordt omschreven, beschikt nu over een eigen, biomedisch kader. Immunologische fenomenen worden nu binnen dit eigen kader geëvalueerd, en niet meer met behulp van een geleende, niet-eigen chemische theorie.

Deze globale transformatie is hier beschreven. Chemici gebruikten een inductieve stijl bij hun onderzoek naar immunologische fenomenen. $\mathrm{Zij}$ onderzochten de specificiteit van de immunologische reactie met chemische technieken en stoffen, en interpreteerden de onderzoeksresultaten in termen van chemische theorieẽn over de structuur van moleculen. (Pauling gebruikte weliswaar een deductieve methodologie, maar zijn benadering kreeg - opvallend genoeg - geen navolging binnen de chemische traditie). Deze benadering resulteerde in de instructietheorie die een aantal 'alledaagse' principes van de immuniteit kon verklaren, maar die principes zelf werden niet (deductief) geproblematiseerd.

In de meer biologische traditie begon men op een hoger abstractieniveau, namelijk de functie van de afweer. Burnet problematiseerde het onderscheid tussen 'eigen' en 'niet-eigen' en ontwikkelde deductief een theorie waarin de functie van de afweer centraal stond. Deze benadering resulteerde uiteindelijk in de nieuwe klonale selectietheorie die een abstracte verklaring gaf voor de 'alledaagse' immunologische principes. De resultaten van het fysiologisch, morfologisch, cytologisch en later chemische onderzoek gebruikten theoretici als Burnet en Jerne om de theorie bij te stellen. Omgekeerd werden nieuwe theoretische variaties later in het empirisch-chemisch onderzoek uitgetest. Theoretisch werd dat mogelijk doordat Crick een relatie legde tussen de functionalistische en de structuralistische benadering. Crick verrichtte geen empirisch onderzoek, maar ontwikkelde een theorie waarin functionalistische en theoretisch-chemische overwegingen werden verwerkt. Theoretische overwegingen over bijwoorbeeld de functie van moleculen legden bepaalde restricties op aan de structuralistische mogelijkheden. Hierdoor kon Crick gebruik maken van de resultaten van het structuralistisch onderzoek van Sanger. De deductief ontwikkelde theorie maakte bepaalde aspecten wan Sangers onderzoek relevant. Omgekeerd waren de functionalistische overwegingen van de theoretici niet direct relevant voor het empirisch-chemisch onderzoek omdat die niet als toetsstenen konden worden gebruikt. Het denkverkeer tussen chemici en theoretici 
was hierdoor in én richting gestremd, of, zoals Jerne in 1967 schreef: '...the two hardly speak to each other. Or rather, a cis-immunologist (de bioloog; H.S.) will sometimes speak to a trans-immunollogist (de chemicus; H.S.); but the latter rarely answers. ${ }^{54}$ Binnen dit eenrichtingsdenkverkeer tussen de functionalistische en structuralistische benadering ontstond het nieuwe specificiteitsbegrip.

Maar belangrijker dan de inhoudelijk-theoretische articulatie van de klonale selectietheorie waren de methodologische ontwikkelingen binnen de deductieve stijl. Een voorspelling van de klonale selectietheorie werd 'omgebouwd' in een regel en resulteerde uiteindelijk in het creëren van samples: monoklonale antilichamen. Deze ontwikkelingen stelden chemici in staat de structuur van antilichamen rechtstreeks te onderzoeken: eerst van de Bence Jones eiwitten en later van willekeurig welk type antilichaam. Het creëren van zuivere samples leidde tot nieuwe methodologische praktijken waarin chemici en biologen konden samenwerken. Dit resulteerde in een verdere uitwerking van de klonale selectietheorie op moleculair niveau waaruil de immunogenetica ontstond.

Uit deze globale schets van de inhoudelijke en methodologische ontwikkelingen in de immunologie kunnen we nu afleiden waar de verschillen liggen tussen de biologie van gedrag en de immunollogie. Bij de kennisontwikkeling in de immunologie is een pendelbeweging waarneembaar tussen de biologische en de chemische traditie. Die vinden we niet alleen op het theoretisch niveau, maar ook op het niveau van de samples. Chemici gebruikten haptenen in hun experimenteel onderzoeken en definieerden antilichamen als substanties die ontstaan als response op de synthetische antigenen. Deze definitie fungeerde lange tijd als regel binnen het experimenteel onderzoek en werd pas later door biomedici als een hypothetische uitspraak opgevat. Impliciet veronderstelde de definitie een instructietheorie en deze theorie diende volgens biomedici vervangen te worden door cen aanlegtheorie. Deze theoretische ontwikkeling leidde uiteindelijk tot de creatie van nieuwe samples. De hypothese: 'én cel produceert én antilichaam', werd omgezet in een regel. Monoklonale antilichamen zijn gecreëerde samples die als standaarden van vergelijking zijn gaan functioneren in het immunologisch onderzoeken. Deze gecreëerde samples hoeven niet, zoals experimenteel gecreëerde fenomenen in de fysica ${ }^{55}$, verkllaard te worden; zij hebben wel ingrijpende gevolgen gehad voor het experimenteel (en klinisch) onderzoek. Door de ontwikkeling van monoklonale antilichamen werden allerlei technieken toepasbaar in het immunologisch onderzoek, zoals bepalingen van de aminozuursequentie en de recombinant-DNA-techniek. Theoretische veranderingen binnen een vakge- 
bied kunnen met andere woorden via de deductieve stijl de mogelijkheden voor experimenteel onderzoek drastisch veranderen.

In het onderzoek naar het gedrag van dieren werden geen samples experimenteel gecreëerd. Hierdoor zijn er verschillen tussen het aanleg-omgeving vraagstuk in de biologie van gedrag en de immunologie. Binnen de biologie van gedrag werd er maar eén organisatieniveau onderzocht, namelijk gedrag. Hoewel er een onderscheid kon worden gemaakt tussen de structuralistische, ethologische benadering en de functionalistísche, sociobiologische benadering, hadden beide betrekking op dezelfde (macroscopische) fenomenen: gedragingen. Bepaalde gedragspatronen (bijvoorbeeld de 'zig-zag dans') functioneerden als samples in het empirisch onderzoek. De (communicatie-) functie van gedrag werd door ethologen én sociobiologen door middel van analogie-redeneringen met menselijk gedrag onderzocht. In het speltheoretisch onderzoek werden nieuwe theoretische variaties gegenereerd die vervolgens in het empirische onderzoek werden onderzocht. De bindende elementen bleven echter de observeerbare gedragspatronen. Men beschreef of manipuleerde gedrag in een experimentele situatie. Aanleg en omgeving hadden hier betrekking op waarneembare gedragspatronen en dat vlak 'dwong' onderzoekers met elkaar te communiceren. Structuur (of de vorm) en functie van gedrag waren wel te onderscheiden, maar waren niet gekoppeld aan verschillende organisatieniveau's. In het debat tussen speltheoretici en ethologen waren de inhoudelijke ontwikkelingen in de speltheorie de reden om methodologisch gedragssamples anders te gaan manipuleren.

In de immunologie waren structuur en functie zowel theoretisch als op organisatieniveau gescheiden: de structuralistische, chemische benadering waarin zuivere samples van chemische stoffen centraal stonden, stond tegenover de functionalistische, biologische benadering waarin cellen, organen, etcetera werden onderzocht. Aanleg en omgeving waren hier in eerste instantie verbonden met de tegenstellingen tussen biologie en chemie. Pas na Cricks centrale dogma kon deze theoretische tegenstelling worden opgeheven. $\mathrm{Na}$ de ontwikkeling van monoklonale antilichamen werden de samenwerkingsverbanden tussen biomedici en chemici verder op het niveau van de samples 'gematerialiseerd': ook op het niveau van de samples kruisten toen hun paden. Inhoudelijke ontwikkelingen resulteerden via de deductieve stijl in de creatie van nieuwe samples die vervolgens experimenteel gemanipuleerd konden worden. De biologische klonale selectietheorie werd methodologisch gereduceerd tot een nieuwe chemische methodologische praktijk rondom gecreëerde samples, waardoor deze theorie vervolgens in moleculair-genetische termen verder kon worden gearticuleerd. 


\title{
7 \\ Aanleg, omgeving en gedrag
}

\author{
7.1
}

Inleiding

Traditioneel maken sommige filosofen een scherp onderscheid tussen natuurwetenschap en sociale wetenschap. Omdat het onderzoeksobject in de sociale wetenschappen een interpreterend subject is, zou men in psychologie en sociologie met wezenlijk andere problemen worden geconfronteerd dan in de natuurwetenschappen. Deze problemen zijn niet te herleiden tot een verschil in de complexiteit van het onderzoeksobject, maar hangen samen met een aantal filosofische problemen. Moet men in de sociale wetenschappen, net als in de natuurwetenschappen, verklaringen ontwikkelen, of juist 'verstehend' te werk gaan? Welke consequenties hebben verschillen tussen regelmatigheden in het gedrag en regelgeleid gedrag voor de onderzoekmethode in de sociale wetenschappen? Dienen sociale wetenschappers de menselijke natuur onafhankelijk van de menselijke cultuur te onderzoeken? Deze lijst van filosofische problemen kan men zo kort of lang maken als men wil.

In dit hoofdstuk wordt één probleem nader onderzocht, namelijk het aanleg-omgeving vraagstuk in de gedragswetenschappen. Daarvoor zal ik een vergelijking maken tussen de manier waarop dit vraagstuk wordt onderzocht in de humane ethologie, de speltheorie en een gebied in de psychologie waar het aanleg-omgeving vraagstuk een prominente rol heeft gespeeld: het intelligentie-onderzoek. Hierbij zal uiteraard de nadruk liggen op verschillen in methodologische stijlen en verschillen in de rollen die samples en regels in de levens- en gedragswetenschappen vervullen. Volgens Popper grenzen onderzoekstradities zich af van alledaagse kennis doordat onderzoekers een deductieve stijl gebruiken bij het ontwikkelen en beoordelen van theorieën. Wanneer we uitgaan van tenminste twee methodologische stijlen, dan kunnen we verwachten dat de manier waarop onderzoekstradities zich afgrenzen van alledaagse kennis afhangt van de methodologische stijl en het gebruik van 
samples. Daarmee is niet gezegd dat onderzoekers met behulp van methodologische stijlen zo maar afscheid kunnen nemen van alledaagse voorstellingen van zaken. Juist binnen de gedragswetenschappen stuit men op problemen vanwege de betekenis die handelingen of gedragingen in het alledaagse leven hebben. Die betekenissen waarmee onderzoekers in de gedragswetenschappen te maken hebben kunnen zij, in tegenstelling tot onderzoekers in de natuur-en levenswetenschappen, niet negeren. Op dit punt kannen we daarom verschillen verwachten tussen de wijze waarop het aanleg-omgeving vraagstuk wordt gepercipieerd door biologen, psychologen en sociologen. Waar biologen het aanleg-omgeving proberen te transformeren tot een strikt biologisch vraagstuk, staan psychologen en sociologen voor de vraag in hoeverre dit vraagstuk los kan worden gezien van bijvoorbeeld het natuur-cultuur probleem, juist omdat het vraagstuk in het alledaagse leven deels een cultureel probleem is met normatieve en ethische aspecten.

Wanneer we verschillen vinden tussen de manier waarop biologen en psychologen wetenschappelijke kennis proberen af te grenzen van alledaagse kennis, dan heeft dat repercussies voor de wijze waarop deze vakken methodologisch functioneren. Een aantal verschillen wordt in dit hoofdstuk onderzocht.

\section{2}

\section{Humane ethologie en speltheorie}

In hoofdstuk 5 zijn ethologische en speltheoretische studies naar het gedrag van dieren aan de orde geweest. Ethologen en speltheoretici houden zich echter niet alleen bezig met het gedrag van dieren, maar hebben ook de pretentie dat hun theorieën toepasbaar zijn op het gedrag van mensen.

De tegenstelling tussen de inductieve, ethologische en de deductieve, speltheoretische benadering vinden we ook in het biologisch onderzoek naar menselijk gedrag. Deze verschillen in onderzoeksstijl kunnen worden uitgewerkt aan de hand van twee typische voorbeelden, namelijk de ethologische studie van Tinbergen naar oorlog bij dieren en mensen en Axelrods speltheoretische verklaring van de verschijnselen die zich in de loopgravenoorlog tijdens de eerste wereldoorlog voordeden.

Voor een goed begrip van de humane ethologie is het belangrijk nog eens de grondslagen van dit vak uiteen te zetten. De ethologie gaat terug op Darwins The Expression of Emotions in Man and Animals. In dit boek liet Darwin zien dat emoties karakteristieke uitdrukkingen in het gedrag van dieren en mensen hebben. Dat emoties karakteristieke uitdrukkin- 
gen in het gedrag hebben is op zich een alledaags gegeven, maar Darwin ging een stap verder: sommige uitdrukkingen in het gedrag zijn soorkarakteristiek. ${ }^{1}$ De glimlach en de lach zijn voorbeelden van gelaatsuitdrukkingen die typisch voor de menselijke soort zijn. Mensen begroeten elkaar door de wenkbrauwen op te trekken en ballen hun vuist wanneer zij boos zijn. Dit lijken op het eerste gezicht triviale constateringen, maar het belang ervan ligt op het vlak van de methodologie. Wanneer emoties soortkarakteristieke uitdrukkingen in het gedrag hebben, dan kunnen die uitdrukkingen biologisch worden onderzocht door de vorm van die uitdrukkingen nauwkeurig te beschrijven. Bekende morfologische en taxonomische technieken worden met andere woorden toepasbaar op gedrag. Dit heeft ten minste twee interessante consequenties.

In de eerste plaats kan de evolutietheorie nu worden gebruikt voor de verklaring van de verschillende vormen van soørtkarakteristieke uitdrukkingen van emoties. Zo heeft van Hooff een hypothese ontworpen over de fylogenie van glimlachen en lachen. ${ }^{2}$ Daarvoor heeft hij de soortkarakteristieke uitdrukkingen van emoties bij verschillende primaten beschreven, geanalyseerd en op basis van hun vorm vergeleken met uitdrukkingen bij mensen. Volgens van Hooff is het 'stille-blote-tandengezicht', een vorm van verzoeningsgedrag dat primaten vertonen wanneer zij worden bedreigd, homoloog met onze glimlach. Het 'ontspannen-open-mond-gezicht', waarbij wel geluiden worden geproduceerd en vooral door primaten tijdens het spelen wordt vertoond, is volgens van Hooff homoloog met onze lach. Beide gedragingen zijn volgens van Hooff geritualiseerde gedragspatronen die zijn ontstaan uit het angstgedrag 'blote-tanden-krijs', maar via verschillende processen. Dat betekent dat de lach en de glimlach via verschillende processen uit een gemeenschappelijke grondvorm zijn ontstaan. Hieruit volgt dat lach en glimlach dus oorspronkelijk niet verschilden in intensiteit, maar aparte gedragspatronen waren met een verschillende afstammingsgeschiedenis. Het onderzoek van van Hooff laat goed het karakter van de ethologische empirische onderzoeksstijl zien. Eerst beschreef van Hooff de vorm van verschillende uitdrukkingen van emoties van verschillende diersoorten en bestudeerde de context waarin die uitdrukkingen werden vertoond. Vervolgens gebruikte hij de evolutietheorie (specifieker: Tinbergens conflicthypothese) voor de verklaring van de vorm van de verschillende uitdrukkingen.

Door de nadruk te leggen op de vorm van gedrag, kunnen ethologen in de tweede plaats de expressies van emoties "neutraal' benoemen en beschrijven. Ethologen hoeven niet meer te zeggen dat een aap 'glimlacht' omdat zijn gelaatsuitdrukking lijkt op die van mensen, maar kunnen deze gelaatsuitdrukking benoemen en beschrijven zonder ge- 
bruik te maken van menselijke psychologische predicaten, bijwoorbeeld: "stille-blote-tanden-gezicht". Dit betekent dat ethologen de voorbeelden die wij in het alledaagse leven gebruiken om de betekenis van psychologische predicaten uit te leggen, nu voor een ander doel (en in een andere context) gebruiken, namelijk als samples voor de uitleg van soortkarakteristieke uitdrukkingen. Wanneer een etholoog dus wijst op iemand die 'lacht" dan legt hij dus niet de betekenis van een alledaags begrip uit, maar gebruikt hij dit voorbeeld als sample voor een soortspecifiek gedragspatroon. ${ }^{3}$

Tinbergens hypothese over oorlog en vrede bij dieren en mensen sluiten nauw aan bij zijn conflicthypothese die in hoofdstuk 5 is besproken. ${ }^{4}$ Voor een goed begrip van menselijke agressie is het volgens Tinbergen essentieel dat agressief gedrag niet onafhankelijk van angstof vluchtgedrag wordt onderzocht, omdat agressie en vlucht extremen zijn op een continuüm waartussen verscheidene gedragspatronen zijn geëvolueerd. Mensen vertonen niet alleen agressief gedrag, maar ook dreiggedrag of verzoeningsgedrag zoals de 'vriendelijke glimlach'. Deze gedragingen worden volgens Tinbergen: '(unlike speech) ... universally understood; they are cross-cultural; they are species-specific. And, incidentally, even within a group sharing a common language, they are often more reliable guides to a man's intentions than speech, for speech (as we know now) rarely reflects our true motives, but our facial expressions often "give us away"'. 5 Deze uitspraak verraadt het toendertijd gangbare romantisch-naturalisme in de ethologische theorievorming (vergelijk hoofdstuk 5). Conform dit romantisch naturalisme heeft Tinbergen dan ook zijn hypothese ontwikkeld over: 'the problem of war, of uninhibited mass killing'. Volgens Tinbergen heeft de culturele evolutie geen gelijke tred gehouden met de biologische evolutie en is de culturele evolutie er mede debet aan dat mensen elkaar gemakkelijk doden. Door de ontwikkeling van wapens is namelijk het directe contact tussen tegenstanders in een gevecht verloren gegaan waardoor soortkarakteristieke verzoeningsgedragingen, zoals de glimlach, niet meer kunnen 'werken'. Die gedragingen zouden in natuurlijke situaties voorkomen dat mensen elkaar doden, net zoals dat bij dieren het geval is.

'Very few aircrews who are willing, indeed eager, to drop their bombs "on target" would be willing to strangle, stab, or burn children (or, for that matter, adults) with their own hands; they would stop short of killing, in response to the appeasement and distress signals of their opponents. ${ }^{.6}$ 
In deze ideeën van Tinbergen en van Hooff over menselijk gedrag is de 'werking' van de inductieve stijl duidelijk te herkennen. Dat blijkt in de eerste plaats uit het feit dat ethologische hypothesen nauw aansluiten bij de manier waarop wij in het alledaagse leven psychologische predicaten gebruiken. In het alledaagse leven rechtvaardigen wij] derde persoonsuitspraken vaak onder verwijzing naar gedrag. De uitspraak 'hij is vrolijk' kan bijwoorbeeld gerechtvaardigd worden door te wijzen op iemand die lacht. Ethologen sluiten bij deze praktijk aan, gebruiken vaak dezelfde, uit het alledaagse leven bekende, voorbeelden, maar gebruiken die voorbeelden voor een ander doel; namelijk voor de uitleg en toepassing van soortkarakteristieke uitdrukking. In het ethogram zijn soortspecifieke gedragingen, zoals de menselijke lach, in hun 'canonieke vorm' weergegeven. In het onderzoek van Van Hooff komt dit aspect duidelijk naar voren. In zijn artikel laat bij afbeeldingen zien van de lach en de glimlach en geeft hij daarna een interpretatie van de vorm van deze soortkarakteristieke gelaatsuitdrukkingen in termen van de evolutietheorie.

In de tweede plaats is met name in Tinbergens hypothese te herkennen hoe hij (het door hem waargenomen) maatschappelijk probleem agressie herformuleert in termen van de ethologische theorie, oftewel: hoe hij een ethologische puzzel probeert te construcren. Redenerend vanuit het 'romantisch naturalisme' ontwikkelde Tinbergen de hypothese dat de mens - net als dieren - van nature 'goed' is, maar door culturele factoren op het 'slechte' pad is beland. De ontwikkeling van wapens bevorderde volgens Tinbergen gedrag dat in natuurlijke omstandigheden niet zou worden vertoond. Mensen, concludeerde Tinbergen moralistisch, zouden elkaar in natuurlijke situaties niet willen doden.

De ethologische theorievorming over menselijk gedrag krijgt meer reliëf wanneer we haar contrasteren met speltheoretische interpretaties. Daarvoor zal ik Tinbergens hypothese over oorlog bij dieren en mensen contrasteren met de speltheoretische verklaring die Axelrod heeft ontworpen voor het 'live-and-Jet-live' systeem. Dit samenwerkingssysteem ontstond spontaan tijdens de loopgravenoorlog in de eerste wereldoorlog en was in feite geheel in strijd met de militaire logica van 'kill or be killed'.

Axelrod heeft een speltheoretische verklaring gegeven voor het ontstaan, het stabiel blijven en de teloorgang van het zogenaamde 'live-andlet-live' systeem in de eerste wereldoorlog. Voor deze verklaring heeft hij zijn speltheoretisch model 'Tit for Tat toegepast op de loopgravenoorlog. Tit for Tat is een evolutionair stabiele strategie die is gebaseerd op het Prisoner's Dilemma. ${ }^{7}$ Bij dit dilemma moeten twee spelers kiezen tussen twee alternatieven: samenwerken of elkaar verraden. Op het 
tijdstip dat zij een keuze moeten maken weten zij niet wat de ander zal doen. Indien beide spelers voor samenwerking kiezen, krijgen zij een relatief hoge beloning; indien zij beide voor verraad kiezen is de beloning relatief laag. De hoogste beloning kan worden verkregen wanneer een speler voor verraad kiest terwijl de tegenspeler voor samenwerking kiest (zie figuur 4, waarin de beloningen in punten staan uitgedrukt).

\section{Figuur 4}

$\begin{array}{lcc} & \text { Samenwerking } & \text { Verraad } \\ \text { Samenwerking } & a=3, b=3 & a=0, b=5 \\ \text { Verraad } & a=5, b=0 & a=1, b=1\end{array}$

De twee spelers A en B van het Prisoner's Dilemma kunnen elk, onafhankelijk van elkaar, kiezen voor samenwerking of verraad. De combinaties van deze keuzes resulteren in vier mogelijke uitkomsten die in de matrix staan weergegeven. De keuzes van A staan horizontaal; de keuzes van $B$ staan verticaal.

Welke strategie moeten de spelers volgen? Wanneer het spel vaak achter elkaar wordt gespeeld, blijkt Tit for Tat een evolutionair stabiele strategie, dat wil zeggen dat deze strategie niet verdrongen kan worden door een 'mutante' strategie die het beter doet. Bij de eerste keer dat het spel wordt gespeeld kiest Tit for Tat voor samenwerking en daarna bij elke volgende keer hetzelfde als de tegenstander daarvoor heeft gekozen.

Tit for Tat kan onder bepaalde condities ontstaan en gehandhaafd blijven. Axelrod heeft dit speltheoretisch model op verschillende situaties toegepast, waaronder het ontstaan van het zogenaamde 'live-andlet-live' systeem in de loopgravenoorlog tijdens de eerste wereldoorlog. ${ }^{8}$ Opgrond van zijn model verwachtte Axelrod dat zelfs in een oorlogssituatie samenwerking kan ontstaan wanneer aan een aantal specifieke voorwaarden is voldaan. Wanneer dezelfde groepen herhaaldelijk interacties hebben en wanneer die groepen verraad kunnen afstraffen, kan volgens Axelrod samenwerking worden verwacht. Aan deze voorwaarden werd volgens Axelrod tijdens de loopgravenoorlog voldaan. $\mathrm{Na}$ de eerste, bloedige gevechten ontstond het 'live-and-let-live' systeem spontaan in lokale situaties aan het front. De spelers van Tit for Tat waren volgens Axelrod de relatief kleine bataljons die gedurende langere tijd tegenover elkaar lagen zodat de soldaten na verloop van tijd wisten met wie zij te maken hadden. In deze situatie kon volgens Axelrod een vorm van geritualiseerd vechten ontstaan waarbij de vuurgevechten 
niet meer gericht waren op het doden van tegenstanders, maar slechts een teken waren voor de mogelijkheid van een afstraffing bij verraad. Deze stabiele strategie ging in het Engelse geval teloor toen de hoofdkwartieren, die tot dan toe geen grip hadden op het 'live-and-let-live' systeem, manschappen de opdracht gaven plotselinge aanvallen ('raids') uit te voeren. Deze aanvallen waren onvoorspelbaar en boden geen mogelijkheden voor een samenwerkingssysteem.

Deze verklaring van Axelrod is een typisch produkt van de deductieve stijl. Dat blijkt in de eerste plaats uit het feit dat zijn speltheoretisch model niet aansluit bij de manier waarop wij in het alledaagse leven psychologische predicaten gebruiken. Axelrod wijst niet, zoals van Hooff dat deed, op overeenkomsten in de vorm van observeerbaar gedrag. Met behulp van Tit for Tat ontwikkelde Axelrod een abstracte verklaring voor het ontstaan, stabiel blijven en de becindiging van het 'live-and-let-live' systeem zonder zich te bekommeren om de details van dit 'samenwerkingsverband'. Het ging hem, in de tweede plaats, alleen om de vraag of in de eerste wereldoorlog voldaan werd aan de voorwaarden van zijn model. Hij probeerde niet, zoals ethologen, een 'maatschappelijk probleem' te herformuleren in termen van een theorie, maar gebruikte het empirisch materiaal als testcase van zijn theoretisch model om het model verder te kunnen verfijnen. De feitelijke details van het 'live-and-let-live' systeem speelden in zijn verklaring geen enkele rol.

\section{3 \\ Ethologie en Psychologie}

Ethologen hebben afscheid genomen van alledaagse voorstellingen van zaken door de vorm van gedragingen centraal te stellen in hun onderzoek. De voorbeelden die wij in het alledaagse leven gebruiken om de betekenis van psychologische begrippen uit te leggen, gebruiken ethologen als samples voor de uitleg van soortkarakteristieke gedragingen. Hierdoor kunnen zij de evolutietheorie gebruiken voor onderzoek naar de vraag hoe menselijk gedrag in de evolutie is ontstaan uit dat van dieren. Op zich is dit geen opzienbarende constatering. Het zall waarschijnlijk iedereen die populariserende ethologische boeken of films heeft bekeken zijn opgevallen. Het bijzondere karakter van de ethologische onderzoeksstijl wordt pas duidelijk wanneer we de ethologie tegenover de psychologie plaatsen.

Om dat te kunnen beargumenteren, wil ik eerst wijzen op het complexe karakter van psychologische predicaten. Psychologische predicaten worden anders gebruikt dan predicaten uit de natuur- of levenswe- 
tenschappen. Wanneer iemand wil weten wat een meter is, dan wijzen wij naar een meetlat en zeggen:' 'de lengte van deze lat is een meter'. Als iemand wil weten wat rood is, dan wijzen wij bijvoorbeeld naar een rijpe tomaat en zeggen: 'dit is rood'. Met andere woorden:" woor de uitleg (en toepassing) van begrippen als 'meter' en 'rood' kunnen wij voorbeelden gebruiken die functioneren alls standaarden voor vergelijking. De voorbeelden kunnen op verzoek worden getoond. Psychologische predicaten lijken in dit opzicht 'af te wijken' van bijvoorbeeld kleurwoorden. Wanneer iemand mij vraagt om een typisch voorbeeld van een 'verwachting', 'intentie' of 'herinnering' te laten zien, dan sta ik met de mond vol tanden. Er zijn immers geen typische voorbeelden of standaarden van vergelijking voorhanden van 'intentie', 'verwachting' of 'herinnering' die op verzoek kunnen worden getoond. Dit verschil tussen psychologische predicaten en predicaten als 'meter' of 'rood' is een bron van tegenstellingen in de psychologie. Wanneer er geen publiek waarneembare standaarden van vergelijking zijn voor psychologische predicaten, dan lijken we te moeten kiezen tussen een 'mentalistische' of een 'behavioristische' opvatting. ${ }^{9}$ Volgens de mentalistische opvatting; ontdekken mensen de betekenis van psychologische predicaten via introspectie. Wat een intentie of een herinnering is kunnen mensen ontdekken via de introspectieve methode. Het probleem voor de introspectieve methode is echter dat die niet tot een definitie van een psychologisch begrip kan leiden omdat er geen privé standaarden van vergelijkingen in de geest zijn. En omdat er geen privé standaarden zijn waarop kan worden gewezen, kunnen psychologische predicaten ook niet via introspectie worden uitgelegd. ${ }^{10}$

Volgens de behavioristische opvatting kunnen psychologische predicaten worden uitgelegd onder verwijzing naar publiek observeerbaar gedrag. Het probleem voor deze behavioristische methode is dat psychologische fenomenen niet gereduceerd kunnen worden tot gedrag. Iemand kan doen alsof hij bang is maar dat niet zijn; iemand hoeft ook niet altijd het gedrag te vertonen dat 'hoort' bij een psychologisch fenomeen.

Behavioristen hoeven echter niet te verdedigen dat psychologische fenomenen gereduceerd kunnen worden tot gedrag. $\mathrm{Zij}$ kunnen ook aansluiting zoeken bij de wijze waarop wij aan anderen psychologische predicaten toeschrijven. Hoewel psychologische fenomenen niet gereduceerd kunnen worden tot gedrag, is gedrag wel een reden om psychologische predicaten aan iemand toe te schrijven. Pijngedrag of een lach is in bepaalde omstandigheden een kriterium om van iemand te zeggen dat hij gewond of vrolijk is. Wij leggen mensen uit wat vrolijk zijn betekent onder verwijzing naar een lach, en door te wijzen naar pijnge- 
drag leren wij kinderen wat het wil zegen dat iemand pijn heeft. Deze vorm van behaviorisme stelt dus niet dat psychologische fenomenen gereduceerd kunnen worden tot gedrag, maar sluit aan bij een gangbare praktijk waarin derde persoonsuitspraken worden gerechtvaardigd onder verwijzing naar gedrag.

Deze laatste vorm van behaviorisme kan 'alledaags behaviorisme' worden genoemd. Het is een vorm van behaviorisme die aansluit bij de alledaagse praktijk, waarin mensen derde persoonsuitspraken rechtvaardigen onder verwijzing naar gedrag. Natuurlijk, mensen wertonen niet alleen gedrag: eerste persoonsuitspraken ('ik ben boos', 'ik bedoel....', etcetera) vormen ook kriteria voor anderen om psychologische predicaten toe te schrijven aan mensen en dit aspect valt buiten het 'alledaags behaviorisme', wanneer onderzoekers zich louter beperken tot de bestudering van gedrag. Van Hooff bijvoorbeeld deed onderzoek naar de fylogenie van lachen en glimlachen en niet naar eerste persoonsuitspraken zoals 'ik ben vrolijk'. Om voor de hand liggende redenen: vergelijkend dierpsychologisch onderzoek naar eerste persoonsuitspraken is niet mogelijk omdat dieren geen taal spreken. Niettemin sluit van Hooffs onderzoek wel aan bij het 'alledaags behaviorisme'.

Het 'alledaags behaviorisme' kan worden onderscheiden van twee gangbare behavioristische varianten, namelijk het metafysisch behaviorisme en het methodologisch behaviorisme. Metafysisch behavioristen ontkennen het bestaan van alle psychische fenomenen behalve gedrag. of, voorzichtiger geformuleerd, alle psychische fenomenen kunnen volgens hen worden herleid tot gedrag. Methodologisch behavioristen laten zich niet uit over het bestaan van psychische fenomenen, maar stellen als eis aan de wetenschappelijke methode dat alleen waarneembare fenomenen - dus gedrag - behoren tot het domein van de psychologie. Hoewel het methodologisch behaviorisme in eerste instantie lijkt op het alledaags behaviorisme, zou ik toch op een verschil willen wijzen. Het alledaagse behaviorisme stelt niet als eis aan psychologisch onderzoek dat alleen waarneembaar gedrag tot het domein van de psychologie behoort, maar sluit aan bij de alledaagse praktijk. In de alledaagse praktijk schrijven wij psychologische predicaten toe aan anderen op grond van gedrag en het is deze praktijk waarbij een gedragswetenschapper aansluiting kan zoeken. De ethologie is een onderzoekstraditie die aansluit bij de alledaagse praktijk en daarvoor is een specifieke verklaring te geven.

Ik heb in het voorafgaande benadrukt dat emoties karakteristieke uitdrukkingen in het gedrag van mensen hebben. De lach of glimlach zijn karakteristieke uitdrukkingen of - in de ethologische terminologie - gedragspatronen. Emoties (en sensaties) nemen in dit opzicht een 
uitzonderingspositie in. In het alledaagse leven schrijwen wij psychologische predicaten toe aan anderen op basis van het gedrag dat zij ten toon spreiden, maar lang niet altijd op basis van karakteristieke gedragingen. 'Weten', 'begrijpen' en 'herinneren' hebben bijvoorbeeld geen uitdrukkingen in het gedrag van mensen. Psychologen die zich bezighouden met het menselijk geheugen kunnen dus niet, zoals ethologen, geheugen-gedrag observeren, beschrijven of classificeren. Het begrip 'intelligerit' wordt soms op basis van gedrag aan iemand toegeschreven, maar is er ook sprake van karakteristiek intelligent gedrag of soortspecifiek intelligent gedrag? 'Intelligent' is eerder een begrip dat wordt toegeschreven aan anderen op grond van zeer uiteenlopende gedragingen.

'Herinneren', 'begrijpen', 'weten' en 'intelligent zijn' hebben geen karakteristieke uitdrukkingen in het gedrag van mensen. ${ }^{11}$ Dit lijstje kan naar believen worden uitgebreid met andere voorbeelden; telkens zullen we tot de conclusie komen dat emoties in dit opzicht een uitzonderingspositie innemen.

Wanneer deze conclusie juist is, dan kunnen we nu beargumenteren waarom ethologen een bijzondere positie innemen binnen de psychologie. Traditioneel stelt men dat ethologen afscheid hebben genomen van alledaagse voorstellingen van zaken door mensen en dieren vanuit een evolutionair perspectief te bestuderen. Het typische van de ethologie zou zijn dat zij een biologische visie representeert op het menselijk gedrag. Wanneer dit het cruciale element van de ethologie zou zijn, dan zou het niet moeilijk moeten zijn om bijvoorbeeld intelligentie, het geheugen of het weten eveneens vanuit een biologisch perspectief te onderzoeken. Er zijn echter geen theorieën die het geheugen of het weten op een ethologische manier onderzoeken, die laten zien dat het herinneringsgedrag bij primaten en mensen homoloog zijn, of die verklaren hoe het herinneringsgedrag bij mensen is ontstaan uit dat van primaten. Dat kan eenwoudig niet omdat herinneren geen uitdrukking heeft in het gedrag van mensen; althans zo gebruiken wij dit psychologisch predicaat niet. Het bijzondere karakter van de humane ethologie moet dan ook primair worden gezocht in het alledaagse gegeven dat emoties karakteristieke uitdrukkingen hebben in het gedrag van mensen. Dit gegeven stelt ethologen in staat om onderzoek te doen naar soortkarakteristieke uitdrukkingen, gedrag te beschrijven, classificeren en vergelijken; kortom om die activiteiten te verrichten die typisch zijn voor morfologen en taxonomen en waarvan de resultaten met behulp van de evolutietheorie kunnen worden geïnterpreteerd. Niet de evolutietheoretische interpretatie van menselijk gedrag onderscheidt de humane ethologie van andere psychologische tradities, maar het feit dat 
die interpretatie mogelijk wordt gemaakt door een alledaags gegeven. Omdat emoties karakteristieke uitdrukkingen in hell gedrag hebben, kunnen ethologen evolutionair onderzoek doen naar de ontwikkeling van soortkarakteristieke uitdrukkingen.

\section{4}

\section{Behaviorisme en mentalisme; vorm en functie}

In het voorafgaande is beargumenteerd waarom ethologische studies een bijzondere plaats innemen binnen de psychologie. De hypothese is geformuleerd dat een van de 'logische ruimtes' van het begrip 'emotie' ethologen in staat stelt evolutionaire puzzels te construeren. In bet vervolg wordt de keerzijde van deze hypothese nader onderzocht. Wanneer biologen en psychologen niet de karakteristieke expressies van emoties, maar intelligent gedrag onderzoeken, hoe richten zij dan hun onderzoek in? Wanneer de hypothese juist is dat het begrip 'intelligentie' niet wordt gerechtvaardigd onder verwijzing naar karakteristieke uitdrukkingen in het gedrag, dan kunnen we verwachten dat biologen en psychologen geen fylogenetische puzzels over intelligent gedrag construeren.

Argumenten voor deze hypothese vinden we allereerst in het psychologisch gedragsonderzoek naar dieren. Aan de hand van de bekende experimenten van Köhler met chimpansees kan dit worden uitgewerkt. ${ }^{12}$ In een bepaalde experimentele setting liet Köhler chimpansees problemen oplossen waarbij de oplossing in feite van tevoren (bij de experimentator) bekend was. Zo vond de chimpansee Sultan bijvoorbeeld dat twee bamboestokken, die in elkaar konden worden geschoven, samen lang genoeg waren om een tros bananen te bemachtigen. De twee stokken waren afzonderlijk te kort om bij de bananen te komen. Omdat de chimpansees de oplossing plotseling vonden en die bij volgende experimenten direct toepasten, concludeerde Köhler dat chimpansees net als mensen inzichtelijk leren. De resultaten van het experiment werden met andere woorden geinterpreteerd naar het model van menselijke leerprocessen.

Köhlers onderzoek laat precies zien in welk opzicht ethologische studies naar de expressies van emoties verschillen van het intelligentieonderzoek. Hoewel ethologen de (bijvoorbeeld communicatie-) functie van gedrag interpreteren naar het model van menselijk gedrag, hoeft dat niet voor de vorm van gedrag. Voor het benoemen en beschrijven van de vorm van gedrag maken ethologen geen gebruik van menselijke psychologische predicaten en kunnen daardoor afscheid nemen van 
alledaagse voorstellinger van zaken. Een anthropocentrische beschrijwing en interpretatie van dier- en mensgedrag heeft in de ethologie plaats gemaakt voor een 'morfologische' beschrijving en een evolutionaire interpretatie. In Köhlers onderzoek is geen afscheid genomen van alledaagse voorstellingen van zaken omdat hij het gedrag van de chimpansees interpreteerde naar het model van menselijk gedrag. Een fylogenetische reconstructie van de evolutie van leergedrag werd dan ook niet gegeven.

Hoewel deze verschillen tussen de ethologie en Köhlers experimenten op het eerste gezicht onbeduidend lijken, zijn zij dat niet. Dat wordt duidelijk wanneer de consequenties van deze verschillen gerelateerd worden aan controversen in de psychologie. Twee consequenties wil ik hier uitwerken: voor de mentalisme-behaviorisme controverse, en voor de tegenstelling tussen vorm en functie.

Ethologen kunnen de debatten tussen mentalisten en behavioristen omzeilen omdat zij aansluiten bij de wijze waarop wij in het alledaagse leven derde persoonsuitspraken rechtvaardigen onder verwijzing naar gedrag. Men kan in abstracto natuurlijk wel kritiek hebben op de ethologie ondat 'mentale processen' worden genegeerd, maar dat is veel moeilijker ten aanzien van de concrete voorbeelden die ethologen onderzoeken, zoals lachen en glimlachen. Dat zijn immers voorbeelden uit het 'alledaags behavioristisch' leven. De grap wan de ethologie is juist dat men hierbij aansluit én hiervan afscheid neemt door die voorbeelden als samples voor soortspecifieke gedragspatronen te gebruiken. Juist daardoor kunnen ethologen de vorm van de expressie van emoties los van de mentalisme-behaviorisme controverse onderzoeken. Omdat psychologen, die intelligent gedrag onderzoeken, geen afscheid hebben genomen van alledaagse voorstellingen van zaken, worden zij wel'achtervolgd' door de tegenstelling tussen mentalisme en behaviorisme. Köhler heeft bijvoorbeeld de experimenten van Thorndike uit de associatie-traditie bekritiseerd. Thorndike plaatste onder andere katten en honden in zogenaamde 'puzzle boxes' waaruit de dieren zich door bepaalde handelingen konden bevrijden. ${ }^{13}$ Wanneer een dier ontsnapte uit de 'puzzle-box', werd het dier met voedsel beloond (of juist bestraft). Beloonde handelingen namen hierdoor in frequentie toe; bestrafte handelingen namen af. Dieren leerden handelingen met andere woorden door 'trial and error' waarbij 'inzicht' volgens Thorndike geen rol speelde. Köhler heeft deze experimenten bekritiseerd omdat volgens hem de dieren door de experimentele situatie geen inzicht kunnen vertonen en noodgedwongen 'terugvallen' op de 'trial and error' strategie. De experimentele methode zorgde ervoor dat dieren passieve stimuliverwerkende machines werden. 
Köhllers kritiek op Thorndike's experimenten snijdt een algemeen probleem aan binnen de psychologie dat te boek staat als de ecologische validiteit van psychologische experimenten, i.e. het probleem of in psychologische experimenten wel recht wordt gedaan aan de situatie in het alledaagse leven. Omdat geen afscheid is genomen van alledaagse voorstellingen van zaken, kunnen experimenteel verkregen resultaten in de psychologie worden bekritiseerd vanuit de sensus communis. Köhler kon Thorndike's experimenten bekritiseren omdat dieren in meer 'natuurlijke' experimentele situaties net als mensen 'inzicht' vertonen. In de natuurlijke situatie vertonen dieren andere gedragingen die in strijd lijken met de behavioristische of associationistische interpretatie van leergedrag en door Köhler werden geïnterpreteerd in termen van de mentalistische Gestaltpsychologie. Deze theoretische discussie tussen de Gestalt- en associatie-psychologie is daardoor tevens verbonden met verschillende empirische data omdat die data afhankelijk zijn van de experimentele situatie. Dit probleem geldt eens te meer wanneer menselijk gedrag het onderwerp van psychologisch onderzoek vormt.

Typisch voor de discussies tussen ethologen en speltheoretici over de functie van 'displays' was dat gedragssamples voor de vorm van 'displays' een bemiddelende rol vervulden (vergelijk hoofdstuk 5). In de 'menselijke' psychologie hebben structuralistische en functionalistische benaderingen ook in verschillende theorieën geresulteerd, maar ontbraken de gemeenschappelijke gedragssamples. Een typisch voorbeeld is de controverse tussen de zogenaamde Ebbinghaus- en Bartlett-traditie in het geheugenonderzoek, een wetenschapsgebied dat nauw verwant is aan het intelligentie-onderzoek. ${ }^{14}$ Ebbinghaus liet een proefpersoon (in dit geval Ebbinghaus zelf) betekenisloze lettergrepen (zoals 'wux' of 'caz') van buiten leren om de rol van aanwezige kennis (en dus betekenisvolle associaties) in het experiment te minimaliseren. Zo probeerde hij het menselijk geheugen te onderzoeken door na te gaan hoe uit de aangeboden informatie door combinaties en associaties die informatie in het geheugen werd 'opgeslagen'. Het menselijk geheugen werd met andere woorden volgens Ebbinghaus opgebouwd uit de elementen uit de omgeving die werden aangeboden. Het geheugen was voor Ebbinghaus dan ook een functie van het (associationistisch) leren. Bartlett heeft deze experimenten van Ebbinghaus bekritiseerd, omdat in het alledaagse leven volgens hem al aanwezige kennis cen cruciale rol speelt bij geheugenprocessen. Volgens Bartlett beschikken mensen over een cognitief schema, gebaseerd op eerdere ervaring, dat een actieve rol vervult bij leer- en herinneringsprocessen. Cognitieve schema's behoren tot de inhoud van het bewustzijn en brengen stmuctuur aan in de ervaring. Bartlett bestudeerde geheugenprocessen in een betekenisvolle context 
en concludeerde dat in deze experimentele situatie het geheugen niet associationistisch functioneert.

In het werk van Ebbinghaus en Bartlett zijn de functionalistische omgevingtheorie en de structuralistische aanlegtheorie te herkennen. ${ }^{15}$ Zoals Thorndike het gedrag van dieren in een 'in vitro' situatie onderzocht, zo bestudeerde Ebbinghaus het geheugen aan de hand van 'zuivere', betekenisloze lettergrepen in een experimentele situatie. En zoals Köhler de nadruk legden op een 'in vivo' analyse van het gedrag van dieren, zo bestudeerde Bartlett het geheugen in een betekenisvolle context. Wat zijn in deze experimenten echter de (gemeenschappelijke) samples van het geheugen-gedrag van de proefpersonen? Die zijn er niet. Net als bij de tegenstelling tussen Köhler en Thorndike, zijn de Ebbinghaus- en Bartlett-benadering in het geheugenonderzoek theoretisch strijdige perspectieven die empirisch gerelateerd zijn aan verschillende empirische gegevens. In beide tradities kan men empirisch onderzoek doen, maar er zijn geen gedragssamples die als gemeenschappelijk referentiepunt in de discussie kunnen functioneren. De overgang van de benadering van Ebbinghaus naar die van Bartlett was niet alleen een theoretische overgang, maar betekende ook dat in andere experimentele settingen andersoortige empirische data moesten worden verzameld.

\section{5}

\section{Het intelligentie-onderzoek}

Met de hypothese dat het begrip 'emotie' wel en het begrip 'intelligentie' niet wordt gerechtvaardigd onder verwijzing naar karakteristieke uitdrukkingen in het gedrag, kan inzichtelijk worden gemaakt waarom biologen en psychologen geen evolutionaire puzzels construeren over intelligent gedrag. Tevens kan met deze hypothese duidelijk worden gemaakt waardoor de tegenstellingen tussen mentalisme en behaviorisme, en tussen vorm en functie, in het geval van het intelligentieonderzoek verbonden blijven met verschillende empirische gegevens. Psychologen observeren niet alleen het gedrag van dieren en mensen, maar hebben ook te maken met het feit dat mensen over een taal beschikken. Wanneer zij mensen aan de hand van taal onderzoeken, dan wordt een nieuw element geintroduceerd dat geen rol speelt in het onderzoek naar diergedrag. Als exemplarisch voorbeeld voor psychologisch onderzoek, waarin taal een belangrijke rol speelt, wordt hier de testpsychologie onder de loep genomen. 
De 1Q-test is in 1905 geintroduceerd door Binet en Simon. Net als bij het geheugenonderzoek van Ebbinghaus en Bartlett bepaalt bij een IQ-test de 'experimentele situatie' wat geldt als 'intelligent gedrag'. De vragen die psychologen aan de onderzochten voorleggen bepalen welk 'gedrag' door psychologen wordt bekeken. Aan de hand van het bekende onderscheid tussen regelmatigheden in het gedrag en regelgeleid gedrag kan het karakter van een IQ-test nader worden geanalyseerd. ${ }^{16}$

Hoewel er een levendige discussie gaande is over een paar apen, gaan filosofen er meestal vanuit dat alleen mensen regels kunnen volgen omdat alleen zij beschikken over een taal. Dieren vertonen wel regelmatige gedragspatronen, maar het ontbreekt hen aan een taal waarmee zij onder verwijzing naar regels gedrag kunnen rechtvaardigen, kritiseren, corrigeren, etcetera. Zij bezitten dus niet echt het vermogen om regels te volgen. Daarom is het plausibel om te veronderstellen dat alleen mensen regels kunnen volgen.

Dit verschil tussen regelmatigheden in het gedrag en regelgeleid gedrag kan worden gebruikt om verschillen tussen de biologie van gedrag en de testpsychologie te karakteriseren. Wanneer ethologen het gedrag van dieren onderzoeken observeren zij de regelmatigheden in het gedrag. Deze geobserveerde regelmatigheden proberen zij vervolgens in termen van de evolutietheorie te interpreteren. Psychologen daarentegen onderzoeken regelgeleid gedrag wanneer zij mensen onderwragen of testen op het kunnen volgen van regels. Bij een intelligentie-test bijvoorbeeld onderzoekt men de 'vermogens' van mensen om bepaalde regels te kunnen volgen door na te gaan of mensen regels herkennen, systematische afwijkingen van regels opmerken, ambiguitteiten ontdekken, etcetera. De test is zo ingericht dat de onderzoeker weet wat mensen zouden moeten doen wanneer zij bepaalde regels kunnen volgen. Regels die psychologen een normatieve rol geven bij de bepaling van iemands intelligentiequotiënt. ${ }^{17}$

Wanneer deze argumentatie hout snijdt, dan verschilt de empirische basis van het IQ-onderzoek van die in het biologisch onderzoek naar de expressies van emoties in het gedrag van dieren en mensen. Ethologen gebruiken bepaalde gedragspatronen als standaarden van vergelijking bij hun empirisch, beschrijvend onderzoek. Testpsychologen daarentegen maken geen gebruik van samples voor (karakteristiek) intelligent gedrag zoals ethologen dat doen, maar construeren een test op basis waarvan een maatstaf wordt geconstrueerd waarmee 'slimme' en 'domme' mensen kunnen worden onderscheiden. Dit verschil in de empirische basis van de ethologie en het IQ-onderzoek kan worden gebruikt om te verklaren waarom de IQ-test omstreden is. Hoewel sommige ethologische interpretaties bekritiseerd zijn, is er geen discussie gevoerd 
ower het gebruik van de gedragspatronen die in het ethologisch onderzoek als standaarden functioneren. In de discussies over het IQ-onderzoek daarentegen zijn niet alleen de interpretaties bekritiseerd, maar is cok de IQ-test het onderwerp van de debatten. Discussies rondom vragen alls: 'meten IQ-testen wel intelligentie' of: 'in hoeverre zijn IQ-testen vrij van culturele bias', zijn serieuze discussie-onderwerpen. Dat ethologen niet en IO-psychologen wel door dergelijke problemen worden achtervolgd, kan begrepen worden met de hier ontwikkelde hypothese. De IQ-test heeft een normatief karakter omdat mensen worden getest op hun vermogens om (in een cultuur gangbare) regels te kunnen volgen. Hierdoor kunnen problemen rijzen rondom de vraag welke regels een normatieve rol moeten worden gegeven, of de gekozen regels geschikt zijn om 'intelligentie' meten, en of de test wel voldoende vrij is van een culturele bias.

De hypothese dat de IQ-test een normatief karakter heeft, heeft ook repercussies voor de manier waarop psychologen hun onderzoek inrichten en de wijze waarop zij kritiek op hun onderzoek verwerken. Die kunnen worden uitgewerkt door de psychologische onderzoeksstijl nader te onderzoeken.

\section{6}

\section{Aanleg, omgeving en cultuur}

De psychologische onderzoeksstijl is een uitvloeisel van de koppeling tussen de IQ-test en de aan het biometrisch darwinisme ontleende heuristiek. ${ }^{18}$ Binet had in het prille begin van deze eeuw een test geconstrueerd om kinderen die op school waren achtergebleven op te sporen. Die test bestond uit onder andere puzzels met een opklimmende moeilijkheidsgraad waarmee kon worden bepaald welke regels kinderen van verschillende leeftijden konden volgen. Deze voor praktische doeleinden geconstrueerde test werd later verbonden aan de heuristiek van de biometrie. Deze heuristiek behelst een sterk beschrijvende wetenschapsopvatting en gaat terug op het werk van Galton en Pearson. Centraal in deze zogenaamde fenomenalistische heuristiek staat de ontwikkeling van statistische methoden waarmee men correlaties kan berekenen tussen verschijnselen. In de psychometrie werd de StanfordBinet test, die ook voor volwassenen kon worden gebruikt, gekoppeld aan het statistisch programma uit de biometrie waardoor psychologen de testscores konden correleren met de meest uiteenlopende factoren, zoals erfelijke factoren en omgevingsfactoren. Deze psychologische 
onderzoeksstijl heeft een aantal consequenties gehad voor ontwikkelingen binnen het IQ-onderzoek, waarvan ik er twee wil bespreken.

In de eerste plaats had de koppeling tussen de fenomenalistische heuristiek en de IQ-test tot gevolg dat de IQ-psychologie zich afscheidde van experimentele (en theoretische) tradities in de biologie en de psychologie. Doordat de nadruk kwam te liggen op de ontwikkeling van testen en statistische methoden, verdwenen inhoudelijke problemen naar de achtergrond en ontstond gaandeweg een kloof tussen de IQ psychologie en de experimentele psychologie (en biologie). ${ }^{19}$ Dat betekende witeraard niet dat ontwikkelingen binnen meer experimentele en theoretische tradities onbelangrijk waren voor de testpsychologie. Als gevolg van ontwikkelingen binnen met name de populatiegenetica wordt er al geruime tijd kritiek geleverd op het IQ-onderzoek. Die kritiek betrof vooral de wijze waarop het aanleg-omgeving vraagstuk in het IQ-onderzoek werd geoperationaliseerd. IQ-psychologen zouden volgens deze kritiek van populatiegenetici het begrip 'heritability' verkeerd gebruiken. ${ }^{20}$ Volgens populatiegenetici is de 'heritability' het deel van de fenotypische variatie in een populatie dat wordt veroorzaakt door genetische variatie. Dit begrip zegt echter niets over de bijdrage van de erfelijkheid aan het (individuele) fenotype. Wanneer de 'heritability' nul procent is, dan betekent dat niet dat genen irrelevant zijn voor de ontwikkeling van een kenmerk, maar dat er geen genetische variatie is in de populatie binnen een bepaalde omgeving. IO-psychologen zouden nu volgens kritici het begrip 'heritability' $z 6$ interpreteren dat het begrip wel iets zegt over de bijdrage van de erfelijkheid aan een fenotype, en dat berust volgens de kritici op een elementair misverstand.

Deze kritiek is door psychologen ter harte genomen en heeft tot een aantal aanpassingen geleid $^{21}$, hoewel in handboeken - zoals Paul ${ }^{22}$ onlangs heeft aangetoond - nog regelmatig wordt gesuggereerd dat psychologen kunnen bepalen hoeveel iemands IQ afhangt van erfelijke factoren. Deze kritiek heeft geresulteerd in een aantal aanpassingen. Men gebruikte andere (achtergrond-) kennis voor de interpretatie van dezelfde gegevens. Dit komt voort uit het feit dat kritiek op de wijze waarop het aanleg-omgeving vraagstuk wordt geoperationaliseerd geen consequenties heeft voor de inrichting van de test. Als gevolg van kritiek kan men wel herberekeningen uitvoeren, fouten of zelfs fraude ontdekken, maar de kritiek leidt niet tot de ontdekking van nieuwe feiten. Kritiek op de (populatie-genetische) theorie die men gebruikt voor de interpretatie van testresultaten heeft immers geen consequenties voor de wijze waarop een test wordt samengesteld: die blijft hetzelfde.

De koppeling tussen de IQ-test en de fenomenalistische heuristiek heeft in de tweede plaats consequenties gehad voor de discussies tussen 
aanlegdenkers en omgevingsdenkers in het $\mathrm{IQ}$-debat. ${ }^{23}$ Wanneer de hypothese juist is dat de IQ-test een normatief karakter heeft, dan verklaart dit waarom in het IQ-debat niet alleen 'feitelijke' maar ook normatieve kwesties op de agenda staan. ${ }^{24}$ Aanlegdenkers zijn van mening dat verschillen in scores samenhangen met genetische verschillen tussen individuen, omgevingsdenkers gaan ervan uit dat in principe er geen genetische verschillen zijn. Individuen zijn gelijk en verschillen tussen individuen komen volgens omgevingsdenkers voort uit verschillende omgevingsinvloeden. Binnen het 1Q-debat zijn deze twee posities tegelijkertijd twee verschillende politieke opvattingen. Volgens aanlegdenkers bestaan er verschillen tussen individuen en kan de IQ-test worden gebruikt als een instrument om 'de juiste man op de juiste plaats' te krijgen. Omgevingsdenkers gaan er daarentegen niet vanuit dat ongelijkheid noodzakelijk bestaat, maar proberen via een IQ-test ten onrechte 'slecht' bedeelde individuen op te sporen. Door compensatieonderwijs zou men deze individuen weer 'op niveau kunnen brengen'.

Deze twee verschillende perspectieven vinden we bijvoorbeeld terug in het debat tussen aanlegdenkers en omgevingsdenkers naar aanleiding van het bekende artikel van Jensen uit $1969 .{ }^{25}$ De aanlegdenkers verdedigden in dat debat het belang van het individu, want het zijn immers de individuen die eigenschappen erven. $\mathrm{Zij}$ waren van mening dat verschillen in scores op een IQ-test, wanneer die voldoende vrij waren van een culturele bias, uiteindelijk te herleiden zijn tot een erfelijke factor. Daar tegenover verdedigden de omgevingsdenkers het belang van compensatieprogramma's om zo door verrijking van de omgeving achtergebleven groepen te integreren in de samenleving. De scores op een test waren voor hen een indicatie voor het niveau op de 'maatschappelijke ladder'. Door compensatieonderwijs zouden minderheden het niveau moeten bereiken van de "mainstream of American life".

Op basis van analyses van verschillende IQ-debatten heeft Harwood de conclusie getrokken dat het feitelijk IQ-debat geen debat is tussen aanlegdenkers en omgevingsdenkers in de biologische betekenis. ${ }^{26} \mathrm{Het}$ debat wordt volgens hem gevoerd binnen de grenzen van een meritocratisch perspectief op de sociale orde en dat perspectief wordt door zowel aanlegdenkers als omgevingsdenkers geaccepteerd. Dat blijkt volgens Harwood uit de keuzes van de onderwerpen die worden bediscussieerd. Men debatteert niet over het verband tussen intelligentie en sociale klassen (wel over rassen) of over de gelijkschakeling van intelligentie met het intelligentiequotiënt, maar voornamelijk over politieke kwesties binnen de grenzen van een meritocratisch perspectief, zoals het belang van het individu, de positie van minderheden, of de rol van het onderwijs in het handhaven van de sociale orde. Harwood conclu- 
deert dan ook dat 'the enormously controversial character of heredity versus environment has arisen out of virtually unexamined and uncontroversial political premisses: ${ }^{27}$

Deze conclusie is maar slechts ten dele juist. Met name binmen de onderwijssociologie hebben zich tradities ontwikkeld die kritiek hebben geleverd op het meritocratisch perspectief. ${ }^{28}$ Het onderzoek wordt volgens deze kritici uitgevoerd binnen het bestaande, meritocratisch gestructureerde, onderwijssysteem: dat wordt voor lief genomen. Ten onrechte wordt volgens hen de inhoud en de structuur van het onderwijs niet ter discussie gesteld. Deze marxistisch getinte kritiek behelst natuurlijk een radicale omgevingstheoric omdat men van mening is dat de bestaande onderwijspraktijk en maatschappelijke verhoudingen ongelijke kansen op deelname aan onderwijs in de hand werken. Uiteraard heeft deze visie repercussies voor de verhouding tussen onderwijssociologisch onderzoek en onderwijspolitiek. In plaats van de nadruk op feiten, waarover bij gratie van het feit dat de meritocratische denkstijl niet ter discussie stond consensus was, kan nu een politieke discussie over de meritocratische denkstijl worden gevoerd. Volgens Harwood en Harbers heeft deze overgang plaatsgevonden binnen de onderwijssociologie in onder andere Engeland en Nederland. ${ }^{29}$ In plaats van een positie buiten de politiek hebben onderwijssociologen in Engeland en Nederland een positie binnen de politiek ingenomen. Onderwijssociologisch onderzoek is dan expliciet het voortzetten van politieke discussies met andere middelen.

\section{7}

\section{Conclusies}

De wijze waarop het aanleg-omgeving vraagstuk in de gedragswetenschappen wordt onderzocht heeft geen eenduidig karakter. In dit hoofdstuk is de hypothese ontwikkeld dat de verschillende manieren waarop het aanleg-omgeving vraagstuk in de gedragswetenschappen wordt onderzocht, begrepen kan worden in termen van de grammatica's van psychologische predicaten. Omdat psychologische predicaten zich in verschillende logische ruimtes 'bevinden', worden psychologische fenomenen op verschillende manieren onderzocht. De humane ethologie neemt binnen de gedragswetenschappen een bijzondere positie in die wordt mogelijk gemaakt door ến van de logische ruimtes van het begrip 'emotie'. Omdat ethologen de voorbeelden uit het 'alledaagse behaviorisme' als samples voor soortkarakteristieke gedragingen gebruiken, sluiten hun studies nauw aan bij het alledaagse gebruik van psychologi- 
sche begrippen. Tegelijkertijd kunnen zij, door de alledaagse voorbeelden voor andere doelen te gebruike $n_{x}$ evolutionaire puzzels construeren en dus afscheid nemen van alledaagse voorstellingen van zaken. In het onderzoek naar intelligent gedrag wan dieren en mensen en het IQ-onderzoek is daarentegen geen afscheid genomen van alledaagse voorstellingen van zaken. Betoogd is dat psychologen in ieder geval niet op ethologische wijze intelligent gedrag kunnen onderzoeken, omdat het begrip intelligentie in het alledaagse leven niet wordt gebruikt onder verwijzing naar karakteristieke uitdrukkingen in het gedrag. Hierdoor blijft in de psychologie de spanning tussen mentalisme en behaviorisme, en tussen vorm en functie, bestaan. Gedragssamples, die in de discussies tussen ethologen en sociobiologen voor een gemeenschappelijk referentiepunt zorgen, ontbreken in het onderzoek naar intelligent gedrag. Hierdoor zijn theoretische tegenstellingen in het onderzoek naar intelligent gedrag tevens verbonden met andersoortige data. Globale theoretische tegenstellingen zijn niet op lokaal niveau op te lossen.

In het IQ-onderzoek observeert men geen regelmatigheden in het gedrag, maar worden mensen getest op hun vermogens om regels te kunnen volgen. Ten aanzien van de IQ-test, die psychologen voor praktische doeleinden hebben geconstrueerd, rijst dan ook voortdurend de vraag in hoeverre de test een adequate representatie is van wat wij normaal gesproken onder intelligentie verstaan. De gemeten testscores kunnen wel worden geïnterpreteerd in termen van achtergrondkennis, maar deze vorm van theorie-ontwikkeling verschilt van die in de biologie van gedrag. Psychologen kunnen niet zoals ethologen evolutionaire puzzels construeren die kunnen worden getest aan de hand van observeerbare fenomenen. Hoewel de psychologische en ethologische onderzoeksstijl ogenschijnlijk niet verschillen, ontbreken in de psychologische onderzoeksstijl de gedragssamples. De psychologische onderzoeksstijl kan daarom worden gekarakteriseerd als een 'geamputeerde inductieve onderzoeksstijl'. Deze stijl heeft tot gevolg dat de ontwikkelde hypothesen voortdurend worden aangepast. Hoewel de oorspronkelijke tegenstelling tussen aanleg en omgeving in het IQ-onderzoek door deze aanpassingen is afgezwakt, blijft die tegenstelling bestaan. Nog steeds gaat het om de vraag in welke mate verschillen tussen groepen of individuen veroorzaakt worden door aanlegfactoren of omgevingsfactoren. En nog steeds blijven de cijfers omstreden. 


\section{8 \\ Controversiële problemen, \\ oplosbare puzzels \\ De biologie en methodolo- \\ gie van aanleg en omgeving}

\section{1}

Inleiding

Het aanleg-omgeving vraagstuk in de levenswetenschappen is volgens sommigen in deze eeuw opgelost. Regelmatig kan men in geschriften lezen dat de oude tegenstelling tussen aanleg en omgeving niet langer houdbaar is. In de argumentatie die auteurs voor deze stellingname aanvoeren wordt vaak benadrukt dat het aanleg-omgeving vraagstuk ondubbelzinnig te beantwoorden is mits de juiste logica wordt gehanteerd. ${ }^{1}$ Aanleg en omgeving zijn factoren die in een functionele relatie tot elkaar staan en die daarom nooit als dichotome categorieën dienen te worden behandeld. Wel kunnen deze factoren in experimentele settingen concreet worden gemaakt en worden geduid in termen van causale factoren. Door hetzij genetische, hetzij omgevingsfactoren te variëren of experimenteel te manipuleren, kan de herkomst van het ontstaan van verschillen tussen individuen eenduidig worden vastgesteld. Maar uit het feit dat verschillen tussen individuen door of aanlegof omgevingsfactoren worden veroorzaakt, volgt niet dat we te maken hebben met een dichotomie. Beidle factoren zijn altijd verantwoordelijk voor het eindprodukt. Volgens deze opvatting is het aanleg-omgeving vraagstuk een oplosbaar probleem, dat alleen nog in exoterische kringen tot controversen leidt. Als onderzoekers dit vraagstuk in termen van de oude tegenstelling formuleren, bestaat een misverstand dat uit de weg te ruimen is. Het aanleg-omgeving vraagstuk is volgens deze opvatting een schijnprobleem: rijp voor historische studies die de vraag dienen te 
beantwoorden waarom onderzoekers vroeger door de 'verkeerde' ideeën telkens werden misleid.

Deze opvatting is gangbaar in onder andere embryologische en populatiegenetische kringen. Vreemd genoeg wordt zij in den treure herhaald waardoor de logische argumentatie yoor de buitenstaander het karakter krijgt van een bezwering. Waarom moet de juiste logica van aanleg- en omgevingsfactoren telkens weer worden herhaald? Als het vraagstuk is opgelost, waarom moet dan steeds weer worden benadrukt dat de tegenstelling tussen aanleg en omgeving een schijntegenstelling is? Deze studie verschaft op deze vragen een dubbelzinnig antwoord: als empirische puzzel is het vraagstuk inderdaad op te lossen, maar als theoretisch probleem leeft het aanleg-omgeving vraagstuk voort.

\section{2 \\ Consensus en conflict}

Wanneer onderzoekers kritiek leveren op de oude aanleg-omgeving tegenstelling, dan leveren zij geen globale theoretische kritiek op de traditionele aanlegtheorieën, zoals Darwins evolutietheorie, of traditionele omgevingstheorieën, zoals leertheorieën. Kritiek wordt geleverd op bepaalde hypothesen die met behulp van de traditionele aanleg- of omgevingsperspectieven zijn geformuleerd. Daarbij wordt gebruik gemaakt van onderzoeksresultaten die de uitkomst zijn van puzzeloplossen. Concreet empirisch onderzoek laat zien dat aanleg-en omgevingsfactoren beide verantwoordelijk zijn voor de ontwikkeling van eigenschappen van individuen. Niet voor niets is er sprake van factoren en niet van een (nieuwe) theorie die speculatieve verbanden legt. In het experimenteel onderzoek zijn deze factoren van elkaar te scheiden en kan men aanleg- of omgevingsfactoren experimenteel manipuleren. Conflicten tussen onderzoekers over de verkregen onderzoeksresultaten hebben een lokaal karakter en hebben betrekking de inrichting van het experiment, het gebruik en prepareren van samples, de grootte van de steekproef, etcetera. Deze lokale conflicten vooronderstellen consensus over het gebruik van samples en regels. Consensus op dit niveau is met andere woorden geen theoretische consensus, maar komt veeleer voort uit het feit dat de onderzoeksresultaten te duiden zijn in termen van regels en samples. Dat aanleg- en omgevingsfactoren beide verantwoordelijk zijn voor de ontwikkeling van biologische produkten, hoeft daardoor in het experimenteel onderzoek niet meer ter discussie te staan. Hoe deze factoren het ontwikkelingsproces van eigenschappen beinvloeden wordt al problematischer, omdat voor de beantwoording 
van deze vraag gebruik wordt gemaakt van theoretische veronderstellingen die worden ontleend aan het traditionele aanleg- of omgevingsperspectief. Daarom geven antwoorden op deze vraag soms aanleiding tot theoretische geschillen. Wanneer de vraag wordt gesteld waarom bepaalde functies zijn ontstaan, dan vraagt men naar de 'uiteindelijke' oorzaken. Antwoorden op deze vraag worden vaak in termen van een aanlegtheorie (of respectievelijk een omgevingstheorie) gegeven. Dan blijkt eens te meer dat het aanleg-ongeving vraagstuk als theoretisch probleem nog steeds voortleeft.

Dat het aanleg-omgeving vraagstuk niet alleen een empirische puzzel, maar ook een theoretisch probleem is, beseffen onderzoekers die het vraagstuk theoretisch onderzoeken of hebben onderzocht, zoals immunologen, moleculair biologen of speltheoretici. In hun geschriften wordt het vraagstuk als een globale theoretische tegenstelling gepresenteerd en bestaan oplossingen uit het verkiezen van de aanlegtheorie of de omgevingstheorie. De overwinning van de klonale selectietheorie op de instructietheorie wordt door Jerne, Medawar en anderen beschreven in het teken van de tegenstelling tussen aanleg en omgeving. ${ }^{2} \mathrm{Jacob}^{3}$ beschrijft in zijn autobiografie dat de 'weerlegging' van de theorie van de adaptieve enzymen opnieuw een overwinning van Darwin op Latmarck betekende, en ook Crick $^{4}$ presenteerde zijn centrale dogma expliciet in het kader van de tegenstelling tussen Darwin en Lamarck. In het sociobiologie-debat tussen sociobiologen en sociale wetenschappers staat aanleg eveneens tegenover omgeving. Niet met betrekking tot de ontwikkeling van gedrag, maar met betrekking tot de vraag of de menselijke cultuur niet een belangrijker verklaringsgrond is dan de menselijke natuur. Tegenover de sociobiologische, gencentrische verklaringen hebben anthropologen en sociologen culturele verklaringen geplaatst die niet met sociobiologische verklaringen te rijmen zijn. Zells onderzoekers in de levenswetenschappen, zoals Lewontin, die beseffen dat de tegenstelling tussen aanleg en omgeving in de embryologic of de populatiegenetica achterhaald is, hebben naar aanleiding van de sociobiologie een omgevingstheorie verdedigd tegenover het 'biologisch determinisme. 5 In het debat tussen de sociobiologische en sociaalwetenschappelijke verklaringen van menselijk gedrag staat de globale juistheid van aanleg- en omgevingstheorieën op het spel. ${ }^{6}$ Het aanleg-omgeving vraagstuk is globaal een theoretisch tegenstelling en lokaal een oplosbare puzzel. Het wordt gekenmerkt door globale conflicten en lokale consensus. 


\section{3}

\section{De Zoeklichttheorie en de Emmertheorie "revisited'}

In deze studie is de theoretische tegenstelling tussen aanleg en omgeving ontleend aan het werk van Popper. Popper heeft beargumenteerd waarom het aanleg-omgeving vraagstuk een theoretisch probleem is dat in termen van de basisschema's van de Zoeklichttheorie en de Emmertheorie kan worden gekarakteriseerd. Deze tegenstelling tussen de Zoeklichttheorie en de Emmertheorie is in deze studie gebruikt om globale tegenstellingen in de wetenschapstheorie en de levenswetenschappen te karakteriseren. In beide gevallen wordt de kern van de tegenstelling volgens Popper gevormd door twee verschillende verklaringsmechanismen: instructie door herhaling versus selectie door trial and error eliminatie. Door deze structurele gelijkenissen tussen verklaringsmechanismen in de wetenschapstheorie en de levenswetenschappen bestaan er affiniteiten tussen enerzijds een aanlegtheorie en de deductieve stijl, en anderzijds tussen een omgevingstheorie en de inductieve stijl. Aanlegtheoretici zullen eerder een deductieve stijl gebruiken, terwijl omgevingstheoretici eerder zullen kiezen voor een inductieve stijl. Op grond van deze affiniteiten kunnen specifieke argumentatiestrategieën van aanlegtheoretici en omgevingstheoretici worden verwacht. Aanlegdenkers zullen de nadruk leggen op het belang van sterke vereenvoudigingen, op het ontwikkelen van hypothetisch-causale verklaringen, en alleen door de theorie relevant gemaakte feiten interessant vinden. Omgevingsdenkers daarentegen zullen veeleer benadrukken dat de wereld complex is, veel waarde hechten aan het verzamelen van concrete data, en heel voorzichtig theorieën ontwikkelen.

Uit Poppers wetenschapstheorie valt af te leiden dat de inductieve stijl in de wetenschappelijke praktijk geen rol van betekenis zou moeten spelen omdat deze stijl epistemologisch niet houdbaar is. In deze studie is echter betoogd dat de zaak in de onderzoekspraktijk eerder omgekeerd ligt: de inductieve stijl vormt de regel; deductief onderzoek de uitzondering. Tijdens inductief onderzoek worden geen theorieën getest omdat de theorie die wordt gebruikt voor het formuleren van hypothesen niet ter discussie staat. Het doel van inductief onderzoek is niet het testen van theorieën, maar het uitbreiden van het toepassingsdomein van een fonds van geaccepteerde theorieën. Deze onderzoeksstijl heeft Popper verkeerd geïnterpreteerd omdat hij de filosofische tegenstelling tussen deductie en inductie heeft geprojecteerd in de onderzoekspraktijk. De constatering dat inductieve generalisaties geen rol van betekenis spelen in de onderzoekspraktijk is in het licht van de methodologische tegenstelling tussen probleemoplossen en puzzelop- 
lossen geen verrassing, omdat inductieve generalisaties bij het oplossen van puzzels geen essentieel onderdeel vormen van de inductieve stijl. Omgekeerd volgt uit de constatering dat onderzoekers hypothesen testen niet dat zij deductief te werk gaan, omdat die hypothesen (tijdens puzzeloplossen) niet worden afgeleid uit een ter discussie staande theorie. Poppers tegenstelling tussen de Zoeklichttheorie en de Emmertheorie dient dan ook in methodologisch opzicht te worden vervangen door de nieuwe tegenstelling tussen probleemoplossen en puzzeloplossen. De rol die kennis in de inductieve stijl speelt kan worden vergeleken met een fonds of reservoir dat klaar ligt voor de interpretatie van fenomenen.

Poppers tegenstelling tussen de Zoeklichttheorie en de Emmertheorie van de geest is in methodologisch opzicht ook op een ander vlak achterhaald. Naast beslissingen over het aanvaarden of verwerpen van basisuitspraken, kunnen we op grond van Wittgensteins latere filosofie verwachten dat ook andere 'typen' uitspraken in de lokale onderzoekspraktijk een rol spelen in beschrijvend en experimenteel onderzoek. Met zowel de Zoeklichttheorie als de Emmertheorie kan het functioneren van grammaticale regels en samples niet worden verklaard. Grammaticale regels kunnen niet worden gerechtvaardigd onder verwijzing naar feiten en functioneren ook niet als theoretische uitspraken. Daarom zijn deze regels niet te herleiden tot ervaring en zijn zij ook niet 'ondergedetermineerd' door ervaring. In methodologisch opzicht zijn deze ideeën van Wittgenstein zowel in strijd met de Zoeklichttheorie als de Emmertheorie.

De oudere tegenstelling tussen inductief-empirisme en deductief-rationalisme moet daarom het veld ruimen voor nieuwe tegenstellingen. Met deze nieuwe tegenstellingen kan een complexer methodologisch beeld worden geschetst van ontwikkelingen rondom het aanleg-omgeving vraagstuk in de levenswetenschappen. Deze toename in complexiteit komt voort uit het feit dat regels, samples, en technieken een belangrijke rol spelen in de lokale onderzoekspraktijk. In plaats van de affiniteiten tussen de deductieve stijl en aanlegtheorieën, en tussen de inductieve stijl en omgevingstheorieën, kan nu preciezer worden beargumenteerd hoe inhoudelijke posities in het aanleg-omgeving vraagstuk samenhangen met methodologische stijlen, regels, samples en technieken.

Wanneer we tegenover de deductieve stijl niet meer het filosofische empirisme plaatsen, maar de inductieve stijl, dan blijven er natuurlijk nog steeds affiniteiten bestaan tussen aanlegtheorieën en de deductieve stijl, en tussen omgevingstheorieèn en de inductieve stijl. Deze affiniteiten zijn nu de extremen van een continü̈m. Tussen deze extremen 
bevindt zich een breed spectrum aan onderzoeksstrategieên, argumentatiestrategieân en handelingsstrategieèn die niet louter in termen van de extreme posities kunnen worden werklaard. Pauling ontwikkelde bijwoorbeeld deductief een ongevingstheorie over de immunologische response en week af van de gangbare, inductief-chemische benadering. Deze 'afwijking' kan natuurlijk worden verklaard door te wijzen op het feit dat hij altijd een buitenbeentje is geweest in de chemie en zich beeft laten inspireren door de werkwijze van theoretisch fysici. Zo'n verklaring bevestigt dat er inderdaad een globale tegenstelling bestaat, maar is geen verfijning van die globale tegenstelling. Wanneer we oog krijgen voor het feit dat de affiniteiten niet louter in termen van de extremen verklaard moeten worden, dan dienen zich nieuwe en interessantere interpretaties aan. De affiniteiten tussen het gebruik van samples, technieken, regels, methodologische stijlen kunnen dan worden gebruikt om specifieke posities te verklaren. Dat ethologen -als aanlegdenkersbijwoorbeeld de nadruk leggen op het belang van 'onbevooroordeeld" waarnemen en een inductieve stijl gebruiken bij hun onderzoek naar het gedrag van dieren en mensen, is op het eerste gezicht een 'afwijking'. Deze nadruk op 'onbevooroordeeld' waarnemen is echter geen afwijking maar komt voort uit het gebruik van specifieke regels en samples. Wie wil weten wat dieren kunnen waarnemen, dient het gedrag van dieren nauwkeurig te observeren en te beschrijven. De expressies van emoties in het gedrag kunnen onderzoekers bestuderen door gedrag te observeren. In beide gevallen zijn het regels en samples die een inductieve argumentatie in de hand werken: 'onbevooroordeelde' waarnemingen vormen het startpunt voor wetenschap. Deze argumentatie komt niet voort uit een 'vals bewustzijn', maar hangt samen met het gebruik van specifieke samples en regels. Daaruit volgt natuurlijk niet dat samples en regels onderzoekers 'dwingen' om het gedrag van dieren en mensen met een inductieve methodologie te onderzoeken. Speltheoretici hebben laten zien dat het gedrag van dieren en mensen heel goed met een deductieve methodologie kan worden onderzocht. $\mathrm{Zij}$ hebben een aanlegtheorie over sociaal gedrag ontwikkeld met behulp van de deductieve methodologie. Ook hier kunnen we specificeren waarom speltheoretici neigen naar een gencentrische aanlegtheorie: door de nadruk op de 'uiteindelijke' oorzaken van sociaal gedrag, stonden genen -als eenheden van evolutie- centraal in het speltheoretisch onderzoek. Het was in de speltheoretische redenering eenvoudiger om genen als de eenheden van evolutie op te vatten. Wanneer onderzoekers de 'onmiddellijke' oorzaken van gedrag onderzoeken, kunnen we eerder verwachten dat genen niet centraal staan in de theorievorming. 
Tussen de extremen bevindt zich dus een breed scala aan onderzoeks-, argumentatie- en handelingsstrategieën die samenhangen met de middelen om puzzels en problemen aan te pakken. Hoe men puzzels en problemen percipieert en behandelt hangt af van samples, regels, technieken en achtergrondkennis.

Een aantal systematische verschillen in de manieren waarop onderzoekers problemen en puzzels oplossen is in deze studie aan de orde geweest. Zo kwam de tegenstelling tussen structuur en functie telkens in de afzonderlijke vakgebieden terug, wat natuurlijk na Darwin niet verwonderlijk is. Tegen de achtergrond van Darwins evolutietheorie is onderzoek naar vorm en functie betekenisvol. Structuralistische en functionalistische benaderingen zijn op handelingsniveau gekoppeld aan de roll van samples en regels. Ethologen bijvoorbeeld leggen de nadruk op de soortspecifieke expressies van emoties en gebruiken de evolutietheorie voor de verklaring van de verschillende vormen van uitdrukkingen. Betoogd is dat deze onderzoeksstijl mogelijk wordt gemaakt door één van de 'logische ruimtes' van het begrip 'emotie'. Chemici analyseren de structuur van moleculen wat samenhangt met het gebruik van samples van zuivere stoffen. Hierdoor zullen zij problemen in de levenswetenschappen eerder in moleculaire termen herformuleren. Wanneer onderzoekers de functie van reacties onderzoeken, gebruiken zij eerder samples op hogere organisatieniveau's. In de immunologie was de tegenstelling tussen aanleg en omgeving lange tijd gekoppeld aan de tegenstelling tussen functie en structuur. Biologisch georiënteerde onderzochten in eerste instantie de functie van de immunologische response voor het gehele organisme. Later heeft Crick de structuralistische, chemische benadering en de functionalistische, biologische benadering met behulp van zijn centrale dogma theoretisch geïntegreerd, waardoor ook de resultaten van het chemisch onderzoek darwinistisch konden worden geïnterpreteerd. Deze laatste ontwikkeling werd mogelijk gemaakt doordat in de deductieve stijl samples werden gecreëerd.

Naast de tegenstelling tussen vorm en functie is ook een andere systematische tegenstelling aan de orde geweest: die tussen 'onmiddellijke' en 'uiteindelijke' oorzaken. Onderzoek naar de 'onmiddellijke' oorzaken leidt eerder tot een inductieve benadering en een nadruk op 'experimenteel-realisme', omdat 'de natuur' aan de hand van samples en regels wordt gemanipuleerd. Onderzoek naar 'uiteindelijke' oorzaken leidt eerder tot een deductieve benadering en theoretisch speculeren. Samples en regels kunnen hier een 'bemiddelende' rol vervullen tussen deductieve en inductieve stijlen, hoewel de manieren waarop onderzoekers met samples omgaan verschillen. In de sociobiologie 
waren ontwikkelingen in de deductieve stijl de aanleiding om samples anders te gaan manipuleren. De deductieve stijl in de immunologie resulteerde uiteindelijk in het creêren wan nieuwe samples. Met deze onderscheidingen kunnen een aantal methodologische verschillen tussen de biologie van gedrag, de chemie en de fysica in kaart worden gebracht.

Tussen de extreme posities, die af te leiden zijn uit Poppers oorspronkelijke tegenstelling tussen de Zoeklichttheorie en de Emmertheorie van de geest, schuift met andere woorden een breed scala aan onderzoeksstrategieën, argumentatiestrategieën en handelingsstrategieën die gekoppeld zijn aan de tegenstellingen tussen structuur en functie, en tussen proximate en ultimate theorieẽn. Deze tegenstellingen hangen op hun beurt weer samen met het gebruik van samples, regels en technieken. Het is dit brede spectrum dat bepalend is voor een positie op het continuüm tussen de extremen die worden gevormd door de aanlegpositie gekoppeld aan de deductieve stijl, en de omgevingspositie gekoppeld aan de inductieve stijl.

\section{4}

\section{Aanleg en omgeving in de levenswetenschappen}

Deze methodologische verfijning van Poppers oorspronkelijke tegenstelling heeft repercussies voor de wijze waarop het aanleg-omgeving vraagstuk in de levenswetenschappen moet worden geëvalueerd. Samples en regels kunnen niet alleen een bemiddelende rol gaan vervullen tussen de deductieve en de inductieve stijl, maar ook tussen inhoudelijke aanleg- en omgevingstheorieën. Op het niveau van de samples kunnen onderzoekers consensus bereiken over bepaalde onderzoeksresultaten juist omdat samples en regels zo'n belangrijke rol vervullen in de lokale onderzoekspraktijk. Naast communicatieproblemen, die op grond van Kuhns wetenschapstheorie kunnen worden verwacht en voortkomen uit het feit dat onderzoekers binnen verschillende disciplinaire matrices worden gesocialiseerd, kunnen we verwachten dat juist samples en regels een 'bemiddelende' functie vervullen in de lokale onderzoekssituatie.

In hoofdstuk 3 is deze spanning tussen de lokale consensus en globaal conflict onderzocht aan de hand van controversen tussen ethologen en behavioristen. De uiltkomst van deze controversen was dat er uiteindelijk onderzoeksresultaten werden geproduceerd die in strijd waren met zowel Watson's behaviorisme als met de ethologie van Lorenz. Deze onderzoeksresultaten waren echter niet de uitkomst van een weten- 
schappelijke revolutie in de Kuhniaanse zin, ondat de trits" puzzeloplossen - probleemoplossen - puzzeloplossen niet opging. Bepaalde hypothesen die waren gegenereerd met behulp van achtergrondkennis waren onjuist, maar die achtergrondkennis zelf stond niet ter discussie. Omdat het 'interactionisme' geen product was van deductieve onderzoek, bleef deze hypothese ingebed in de oudere aanlegtheorieën en omgevingstheorieën die als achtergrondkennis functioneerden. Dit leverde een antwoord op de vraag waardoor onderzoekers, zodra zij gaan discussiëren over het aanleg-omgeving vraagstuk, gemakkelijk vervallen in de tegenstelling tussen aanleg en omgeving. In de 'esoterische', lokale onderzoekssituatie, waar onderzoekers met behulp van samples en regels de 'natuur' prepareren en daardoor relatief eenvoudig overeenstemming kunnen bereiken over bepaalde concrete onderzoeksresultaten, kunnen zij als ware zien dat de dichotomie tussen aanleg en omgeving onbruikbaar is. Theoretische discussies daarentegen raken 'losgekoppeld' van het empirisch onderzoeksmateriaal waardoor in met name 'exoterische' kringen aanleg weer tegenover omgeving komt te staan. Dit wordt versterkt doordat in theoretische discussies onderzoekers veelvuldig gebruik maken van analogie-redeneringen en metaforen. Het is dan ook niet verwonderlijk dat het 'interactionisme' vaak wordt verdedigd met een beroep op experimenteel realisme terwijl theoretisch speculeren wordt veracht.

Dat studies naar de ontogenie van gedrag ingebed blijven in achtergrondkennis blijkt eens te meer wanneer we bijvoorbeeld de verhouding tussen ontogenie en fylogenie problematiseren. Hoe men deze relatie ook verklaart, duidelijk is wel dat ontogenetische argumenten altijd kunnen worden gebruikt om evolutionair-genetische verklaringen te kritiseren en vice versa. Met behulp van de evolutietheorie kan men bepaalde verklaringen genereren over ontogenetische ontwikkelingspatronen en die gebruiken om 'proximate-verklaringen' te herinterperteren. Omgekeerd kunnen ontogenetische verklaringen worden gebruikt om 'ultimate-verklaringen' te ontkrachten. Deze problematische verhouding tussen 'proximate' verklaringen en 'ultimate' verklaringen is in hoofdstuk 5 nader onderzocht aan de hand van de sociobiologie. Daaruit kwam naar voor dat sociobiologen via een wiskundige heuristiek theoretische modellen ontwikkelden wat resulteerde in een voorspelling die in strijd was met een ethologische hypothese. De theoretische discussie tussen ethologen en speltheoretici werd later getransformeerd in een empirische discussie waarin samples en regels centraal stonden. Door de discussie te koppelen aan specifieke gedragssamples, was de controverse wederom op dit niveau te beslechten. 
In de biologie van gedrag werden (macroscopische) fenomenen onderzocht en hadden structuur en functie betrekking op -per definitiedezelfde gedragspatronen. De gedragspatronen of gedragssamples fungeerden hier als bindende elementen tussen de ethologie en de sociobiologie, hoewel het startpunt in de argumentaties van ethologen en sociobiologen verschillend was. Ethologen onderzochten primair de vorm van gedrag en pas in tweede instantie de overlevingswaarde of functie van gedragingen. Bij sociobiologen lag dit precies omgekeerd: zij begonnen huin onderzoek bij de functie van gedrag en 'daalden' pas later af naar de vorm van gedrag. In hoofdstuk 6 keerde deze tegenstelling tussen structuur en functie in een andere gedaante terug. Ook binnen de immunologie konden structuralistische en functionalistische benaderingswijzen worden onderscheiden. Deze twee benaderingswijzen waren binnen de immunologie echter tevens gekoppeld aan verschillende functies van samples. Chemici onderzochten de immunologische response in een in vitro situatie met behulp van synthetische stoffen; biologisch georiënteerde onderzoekers onderzochten de functie van deze response voor het gehele organisme. De globale theoretische tegenstelling werd hier in de lokale onderzoekspraktijk uiteindelijk opgeheven door via de deductieve stijl samples te creëren. Het creëren van samples trad binnen de biologie van gedrag niet op.

Zowel in de biologie van gedrag als in de immunologie vervulden samples en grammaticale regels een belangrijke rol in het empirisch onderzoek. Het doel waarvoor en de context waarin samples werden gebruikt verschilde echter. Hiermee konden een aantal verschillen worden verklaard tussen het aanleg-omgeving vraagstuk in de biologie van gedrag en de grensgebieden tussen chemie en biologie. In hoofdstuk 7 is de keerzijde van dit probleem nader onderzocht: de verschillen tussen de levenswetenschappen en de gedragswetenschappen zijn daarin geanalyseerd. Cruciaal voor de humane ethologie was dat de voorbeelden, die wij in het alledaagse leven voor de uitleg van de betekenis van psychologische predicaten gebruiken, door ethologen voor de uitleg van soortkarakteristieke gedragspatronen werden gebruikt. Betoogd is dat ethologen op deze wijze afscheid kunnen nemen van het alledaagse gebruik van psychologische begrippen omdat een grammaticale regel hen hiertoe in staat stelt. Omdat emoties karakteristieke uitdrukkingen in het gedrag hebben, kunnen ethologen onderzoek doen naar soortkarakteristieke uitdrukkingen. Psychologen die intelligentie-onderzoek verrichten kunnen niet op deze wijze afscheid nemen van het alledaagse gebruik van het begrip intelligentie ondat dit begrip niet wordt gerechtvaardigd onder verwijzing naar karakteristieke uitdrukkingen. Typerend voor het IQ-onderzoek is dat psychologen mensen testen op hun 
vermogens om regels te kunnen volgens, Dit heeft een aantal consequenties. In de eerste plaats leek het alsof psychologen hun onderzoek conform de inductieve stijl inrichten, maar werden tegenvoorbeelden louter aangepast. Kritiek op de achtergrondkennis had geen consequenties voor de wijze waarop de test werd ingericht en daarom is deze onderzoeksstijl gekarakteriseerd als een 'geamputeerde inductieve stijl'. In de tweede plaats had het testen van de vermogens om regels te kunnen volgen als consequentie dat binnen het IQ-debat ook normatieve zaken op de agenda staan. Bijvoorbeeld het meritocratisch perspectief op de sociale orde dat wordt voorondersteld bij het IQ-onderzoek is door onder andere onderwijssociologen ter discussie gesteld. Natuurlijk is de humane ethologie en sociobiologie fel bekritiseerd door omgevingsdenkers. Die kritiek heeft echter geen invloed gehad op de 'interne' theorie-ontwikkeling binnen de biologie van gedrag. Terwijl binnen de levenswetenschappen 'feitelijke' discussies en 'normatieve' discussies via het gebruik van samples (en via methodologische regels) zijn te onderscheiden en via verschillende schijven verlopen, zijn feitelijke en normatieve elementen in de sociale wetenschappen niet via deze weg uit elkaar te trekken omdat men in de sociale wetenschappen geen afscheid heeft genomen van alledaagse voorstellingen van zaken.

\section{5 \\ Slot}

In deze studie zijn in feite de ideeën van twee filosofen gebruikt om de biologie en methodologie van het aanleg-omgeving vraagstuk te verhelderen. Wittgensteins ideeën zijn gebruikt om lokale kwesties rondom het gebruik van samples en regels te interpreteren. Poppers tegenstelling tussen de Zoeklichttheorie en de Emmertheorie is gebruikt om de globale tegenstelling tussen aanleg en omgeving te onderzoeken. In tegenstelling tot gangbare Popper-en Wittgenstein-interpretaties, zijn de ideeën van deze auteurs niet tegenover elkaar geplaatst. Deze keuze hangt nauw samen met ontwikkelingen rondom het aanlegomgeving vraagstuk in de levenswetenschapen. In de levenswetenschappen heeft dit vraagstuk in deze eeuw in verschillende gebieden transformaties ondergaan waardoor de huidige problemen en puzzels een ander karakter hebben gekregen. Die veranderingen kunnen niet adequaat met behulp van Poppers tegenstelling tussen de Zoeklichttheorie en de Emmertheorie worden beschreven en geëvalueerd omdat daarmee slechts globale theoretische transformaties kunnen worden beschreven, zoals de overgang van de instructietheorie naar de klonale selectietheo- 
rie, of de overgang van Lamarcks naar Darwins evolutietheorie. Naast deze globale transformaties kunnen ontwikkelingen in de lokale onderzoekspraktijk worden onderscheiden. Deze laatste ontwikkelingen zijn in deze studie geanalyseerd aan de hand van Wittgensteins ideeën over het functioneren van samples en regels in de lokale onderzoekspraktijk. Zijn ideeênn zijn hier als kritiek op en als complement van Popper wetenschapsfilosofische ideeên gepresenteerd. Welke consequenties volgen uit deze kritiek op en uitbreiding van het Popperiaanse beeld voor oplossingsstrategieën voor de biologie en methodologie van aanleg en omgeving?

Het aanleg-omgeving vraagstuk is een filosofisch vraagstuk dat haar oorsprong heeft in het werk van Plato. Ruim tweeduizend jaar na Plato worstelen filosofen nog steeds met dezelfde problemen en van enige vooruitgang lijkt geen sprake. Popper kritisch rationalistische filosofie staat in de Platonistische traditie. Volgens Popper heeft Plato wereld-3 ontdekt; de wereld van de ideeën of zuivere vormen. ${ }^{7}$ Maar in tegenstelling tot Plato stelt Popper dat deze ideeën produkten zijn van de menselijke geest: het zijn wetenschappelijke theorieën die waar of onwaar kunnen zijn en die verbeterd kunnen worden. Omdat Popper een dynamische kijk heeft op wereld-3, is Popper optimistisch over de verbetering van de ideeën die in deze wereld huizen. Globale transformaties kunnen volgens hem nooit wordeñ uitgesloten en dat geldt zowell ten aanzien van wetenschappelijke als filosofische ideeën. Ideeën blijven volgens Popper altijd de status behouden van vermoedens waarover wij nooil zekerheid kunnen verkrijgen. Vertaald naar de biologie en methodologie van aanleg en omgeving betekent dit dat de ideeën over aanleg en omgeving de status van een vermoeden hebben.

Wittgenstein was pessimistisch over vooruitgang in de filosofie; niet over vooruitgang in de wetenschappen. In de filosofie kan geen vooruitgang op wetenschappelijke wijze worden geboekt omdat filosofische problemen geen wetenschappelijke problemen zijn. Wittgenstein: 'philosophers are no nearer to the meaning of "reality", than Plato got, ....' "Welche seltsame Sachlage. Wie sonderbar, dass Platon dann überhaupt so weit kommen konnte! Oder, dass wir dann nicht weiter kommen konnten! War es, weil Platon so gescheit war? ${ }^{8}$ De door Plato geformuleerde problemen blijven bestaan omdat de taal waarin deze filosofische problemen zijn geformuleerd grotendeels hetzelfde is gebleven. De alledaagse taal misleidt filosofen: zij suggereert filosofische problemen die op te lossen zijn. Filosofische problemen zijn volgens Wittgenstein echter geen wetenschappelijke problemen die op natuurwetenschappelijke wijze kunnen worden opgelost. Filosofen kunnen proble- 
men hoogstens oplossen zoals suiker in water wordt opgelost: aantonen dat er geen probleem was.

Een aantal van Wittgensteins ideeën zijn 'vertaald' naar de levenswetenschappen door het sample- en regelbegrip te introduceren en deze begrippen te koppelen aan verschillen tussen de natuur-, levens- en gedragswetenschappen. Het aanleg-omgeving vraagstuk werd daardoor mér dan een theoretisch probleem waarover wij een aantal uitgewerkte vermoedens hebben. Vermoedens die methodologisch alle dezelfde status hebben en via dezelfde deductieve weg verbeterd kunnen worden. Aan Wittgensteins ideeën is ontleend dat de status van de vermoedens verschilt omdat zij steeds op verschillende manieren zijn ingebed in methodologische praktijken rondom samples en regels. Psychologen die intelligent gedrag onderzoeken hebben met andere samples en regels te maken dan biologen die levende wezens onderzoeken of chemici die 'levenloze' stoffen analyseren. Door deze 'grammaticale' verschillen, verschillen ook de praktijken rondom samples. Psychologen kunnen natuurlijk wel random een steekproef samenstellen uit een menselijke populatie, maar beschikken niet over samples voor soortspecifiek intelligent gedrag. Chemici kunnen zuivere samples van stoffen over de gehele wereld mobiliseren en stoffen laten fuseren of splitsen. Biologen kunnen cellen aanzetten tot de productie van bepaalde stoffen of cellen laten groeien, maar het 'splitsen' van een cel leidt tot 'levenloze' moleculen. Deze praktijken rondom samples en regels zijn medebepalend voor het karakter van de oplossingsstrategieën voor het aanleg-omgeving vraagstuk in de verschillende vakgebieden. Deze conclusie is in deze studie geillustreerd en beargumenteerd aan de hand van voorbeelden uit verschillende vakgebieden. De illustraties zijn gebruikt om de inhoudelijk-biologische ontwikkelingen in de verschillende vakgebieden te beschrijven. Daaruit bleek dat de discussies steeds een ander karakter hadden. Wetenschappers onderzoeken niet, zoals op grond van Poppers kritisch rationalisme kon worden verwacht, het aanleg-omgeving vraagstuk in willekeurig welk vakgebied met behulp van steeds dezelfde deductieve strategie. Samples en regels hebben een plaats in methodologische praktijken en staan niet louter ten dienste van het oplossen van gewaagde ideeën. Voor Popperianen zijn samples en regels belemmeringen die via deductief onderzoek uit de weg moeten worden gebruikt. Volgens Wittgenstein belemmeren de regels van de taal het zicht op de vraag of, en zo ja hoe, er sprake is van een hanteerbaar probleem. De filosofische vraag of er sprake is van problemen of schijnproblemen keerde in het geval wan de levenswetenschappen terug in de vorm van de spanning tussen globale theoretische problemen en lokale praktijken rondom samples en regels. Samples en 
regels leggen restricties op aan de methodologische mogelijkheden om de biologie van aanleg en omgeving te bedrijven. Volgens Popper is het denkbaar dat we theorieen ontwikkelen die de praktijken rondom samples en regels 'overstijgen'. De ontwikkelingen binnen moleculaire biologie illustreren Poppers positie en laten zien dat 'leven' een nieuwe betekenis kan krijgen. Het tijdschrift Life vatte de moleculair biologische visie in eên zin samen: 'DNA maakt RNA, RNA maakt eiwitten, en eiwitten maken ons'. Theoretisch is de moleculair biologische visie op leven een denkbare verklaring, een vermoeden dat kan worden herzien. Maar de regels voor het begrip 'leven' zijn er niet door gefalsificeerd en blijwen een belangrijke rol spelen in de lokale onderzoekspraktijk. De biologie van aanleg en omgeving blijft onlosmakelijk verbonden met de methodologie van aanleg en omgeving. 


\title{
Noten
}

\author{
1

\section{Aanleg en Omgeving}

1 F.M. Burnet, "A modification of Jerne"s theory of antibody production using the concept of clonal selection", The Australian Journal of Selence, $20(1957), 67-69$.

2 F.M. Burnet, 'Foreword to first edition', in: L. Hudson en F.C. Hay, Practical immunology, Oxford $1980,2 e \mathrm{dr}$, p. xii.

3 N.K. Jeme, "The complete solution of immunology', Australasian Annals of Medieine $4(1969)$, p. 348.

4 J.J. wan Loghem, Verweer en zlekten, Rede, Amsterdam 1959, p. 5.

5 W.C. Boyd, Fundamentals of immunology, Londen 1966, 4 e dr, p. 97.

6 Vergelijk onder andere N.K. Jerne, 'Antibodies and learning: selection versus instruction, in: G.C. Quarton e.a.(red.), The neurosclences: a study program, New York 1967, 200-205, en P. en J. Medawar, The life science, New York 1977.

7 Zie vooral K.R. Popper, Objective knowledge, Oxford 1972, hoofdstuk 2 en appendix 1 , en K.R. Popper, Unended quest, Londen 1976, hoofdstuk 37.

8 Zie L. Boon, Geschledemis van de psychologle, Meppell 1982, p. 46-48.

9 Vergelijk bijvoorbeeld T.H. Leahey, A history of psychology, Englewood Clifs, 1987, 2e dr., hoofdstuk 13,14 en 15.

10 Geciteerd in LJ. Pongratz, Problemgeschichte der Psychologie, Bern 1967, p. 68-69.

11 Zie D.L. Krantz en D. Allen, The rise ano fall of McDougall's instinct doctrine", Journal for the History of the Behavioural Sclences, 3(1967), 326-338.

12 Vergelijk onder andere T.L. Hankins, Sclence in the enllighteament, Cambridge 1985, hoofdstuk 5, en J.M. Oppenheimer, Essays in the history of embryology and biology, Cambridge 1967 .

13 K. Lorenz, The comparative method in studying innate behaviour patterns", Symposia of the Soclety for Experimental Biology, 41(1950), p. 232.

14 N. Tinbergen, 'An objectivistic study of the innate behaviour of ani-mals', Bibliotheca Blotheorellca, $1(1942)$, p. 39.

15 Geciteerd in H.F. Judson, The elghth day of creatlon), Londen 1979, p. 488.

16 L. Pauling, 'Fifty years of progress in structural chemistry and molecular biology', Daedalus, $99(1970)$, p. 1005 .

17 C. Darwin, The descent of man, and selection in relation to sex, $2 e \mathrm{dr}$. New York 1889, p. 399 .

18 R. Fisher, The genetical theory of natural selectlon, Oxford 1930 , hoofdstuk 6 .

19 R.A. Fisher, op. cit., noot 18, p. vii-x.

20 R.A. Fisher, op. cit., noot 18, p. ix.

21 R. Dawkins, The seirish gene, Oxford 1976, hoofdstuk 9.

22 Vergelijk onder andere M. Sahlims, The use and abuse of blology, Londen 1977.

23 Zie voor een analyse van de controverse tussen Wilson en Lewontin: U. Segeratralle, "Colleagues in conflict: an "In Vivo" analysis of the sociobiology controversy", Blology and Phllosophy, 1(1986), 53-87.

24 U. Segerstrale, op. cit, noot 23, p. 63

25 U. Segerstrale, op. cit, noot 23, p. 67.

26 Zie bijvoorbeeld K. R. Popper, 1972, op. cit., noot 7, p. 70-71.

27 D.O. Hebb, 'Heridity and environment in animal behavior', Animal Behavlour, 1(1953). $43-47$.

\section{2}

\section{Methodologische sti]llen}

1 T.S. Kuhn, The essentlal tension, Chicago 1977, hoofdstuk 3. 
2 L. Woon, "Metbodologie wen wertsehapelinge praktik: de ontdekling wan de struchur

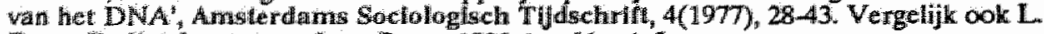
Boon, De list der ellensehap, Barn 1983, hoofdstuk 5 .

3 T.S. Kuhn, op. cit., noot 1. p. 64.

4 L. Bown, 1977, op. citt., nool 2, p. 41.

5 Vergelijk bijwoorbceld L. Boon, 1983, op, cit noot 2, hoofdistuk 1 , en T.S. Kuhin, Selenithe development and lexical change," The Thatheimer lectures, 1984, "lecture' 1.

6 K Popper, Reallsm and the alm of sclence, Londen 1983, p. 47 ew. Zie ook KR Popper, conjeritures and refutallons, Londen 1965, 2e dr., vooral de inleiding, 3-30.

7 KR Popper, 1983, op. cit. noot 6.

8. T.S. Kuhn, op cit. noot 1, hoofdstuk 9.

9. K. Popper, Nomal science and its dangers", in: I. Lakatos en A. Musgrawe(red.), Crituetsin and the growth of knowledge, Cambridge 1970, 51-59.

10 K. R Popper, 1983 , op. cill., noot 6.

11 K.R. Popper, 1983, op, cili, noot 6, p. 48 e.v.

12 KR. Popper, 1983, op. cil "noot 6, p. 40 41 .

13 K.R. Popper, 1983, op. cit , noot 6, p. 41-42.

14 Mijn reconstructie is voornamelijk gebaseerd op G. MacFarlane, Alexander Flemings the mian and the myth, Londen 1984.

15 Geciterd in G. MacFarlatine, op. cilt., now 14, p. 178.

16 K.R. Popper, Ohjectlive knowledge, Oxford 1972, hoofdstuk S.

17 "T.S. Kuha, The essential tension, Chicago 1977, hoofdstuk 11, en T.S. Kuhn, The structure of sclentlific revolullons, Chicago $1970,2 \mathrm{edr}$, vooral hoofustuk 3 en 4 .

18 F. Karush, "Immunologic specifity and molecular structure', Adwances in Immunology, vol. 2,1963 p. 2 .

19 F. Karush, op. cit, noot 18 , p. 3.

20 ZleT.S. Kuhn, Wack-Body radlation and the quantum discontiunulty, 1894-1912, New York 1978. Voor een vergelijkbare ontwikkeling in het begin van deze eeuw rond de eigenschappen vain licht, zile B.R. Wheaton, The Higer and the sharks emplrical roots of wave-particle dualism, Cambridge 1983.

21 Vergelijk L. Boon, 1983, op. cit., noot 2, hoofdstuk S, en T.S Kuhn, 1977, op cit. noot 1, voor een tutgebreide witeenzetting van de verschillen tussen de inductieve en de deductieve tijl. Zie ook L. Boon en H. Smit, 'Sociobiologische onderzoeksstijl en popularisering, Kennis en Methode, 9(1985), 319-333, en G.H. de Vries en L. Boon, 'Een intellectuele zeppelin en zijn bemanning, Kennis en Methode, 10(1986), p. 28-41. Voor de historisch-sociologische achtergronden wan de deductieve en inductieve stijl, zie T.S. Kuhn, op. cit. noot 1; I. Hacking, The emergence of probability, Cambridge 1975 ; en B.J. Shapiro, Probability and certainty in seventeenth-century England, Princeton 1983. Van belang is verder het recente onderzoek van Shapin en Schaffer naar de opkomst van de experimentele 'levensvorm'; zie onder andere S. Shapin en S. Schaffer, Levialhan and the air pump: Hobbes, Boyle, and the expertmental lire, Princeton 1985; $S$. Shapin, "Robert Boyle and mathenatics: reality, representation, and experimental practise", Sclence In Context, 2(1988), 23-58; en $S$. Shapin, The house of experiment in seventeenth-century England', ISIS, 79 (1988), 373-404. Voor een toepassing van het onderscheid tussen de inductieve en deductieve stijl in de kunstgeschiedenis, zie S. Alpers, The art of describing Londen 1983.

22. Zie G. MacFarlane, op. cit, noot 14, hoofdstuk 18.

23 F.M. Bumet, "A modilication of Jerne"s theory of antibody production using the concept of clonal selection', The Ausirallan Jourmal of Sclence, 20(1957), p. 68 .

24 F.M. Burnet, Changing patterns; an atypleal aituloblography, Mébourne 1968, p. 206.

25 F.M. Burthet, op. cit., noot 24, p. 206. Vergelijkbare uitspraken vindt men bij andere deductivisten. 20 zei Prancis Crick dat hij altijd heeft getwijfeld bij het publiceren van zijn dideeen, "partly because if you: are a professional theoretician as I am, you cannot alford to publish too many wrong ones.' Cieciteerd in R. Olby, "Francis Crick, DNA, and the central dogma', Daedalus, $99(1970)$, p. 965.

\section{3}

\section{De ontwlkkeling van gedrag}

1 Kuhn heeft zijn incommensurabiliteitsthese ontwikkeld in The structure of sclentific revolutlons, Chicago $1970,2 \mathrm{e}$ dr. In zijn latere werk heeft hij deze these verder verfijnd en uitgewerkt; zie T.S. Kuhn, 'Reflections on my critics", in: I. Lakatos en A. Musgrave(red.), Crilicism and the growth of knowledge, Cambridge 1970, 231-278; T.S. Kuhn, 'Commensurability, comparability, communicability", Philosophy or Science Associa- 
tlon, 2(1982), 669-688; T.S. Kuhn, Selentilfe developmewt and lextcal change, The Thalheimer Lectures 1984.

2 T.S. Kuhn, "Theory-change als structure change: comments on the Sneed formalism", Erkenninis 10(1976), p. 191.

3 T.S. Kuhn, $1970_{4}$ op. cit, noot 1, p. 187 e.w.

4 Voor de geschiedenis van het behaviorisme, wergelijk onder andera, B. Mackenzie, Behaviourism and the llmits of scientific method, Londen 1977 .

5 J.B. Watson, Behaviourism, New Yorlk 1930, 2 e dr $r_{\text {, }}$ p. 17. Voor de ontwikkeling van Watsons visie op instincten, zie D. Cohen, J.B. Watson; the fouinder of beliaviorism, Londen 1979, p. 242 e.v.

6 Vergetijk R.J. Hernnstein, "Nature as nurture: behaviorism and the instinct theory", Behaviorism, 1(1972), 23-52

7 Over de geschiedenis van de ethologie zijn recent cen asutall artikelen en boeken

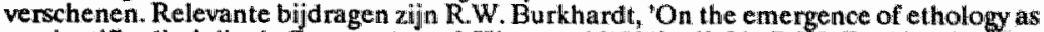
a scientific discipline", Conspectus of History, 1(1981), 62-81; R.W. Burkhardr, The development of an evolutionary ethology, in: D.S. Bendall(red.), Ewolution from molecules to men, Cambridge 1983,429-444. D.A. Dewsbury(red.), Leaders in the study of gnimal behavlor, Londen 1985; J R. Durant, "Inmate character in animals and man: a perspective on the origin of ethology, in: C. Webster(red.), Bhology, medicine and soctety; 1840-1940, Cambridge 1981, 157-192; "T.J. Kalikow, 'History of Konrad Lorenz"s ethological theory, 1927-1939, Studies In History and Philosophy of Selence, 6(1975), 333-341; TJ. Kallikow, "Konrad Lorenz's ethological theory, 1939-1943: "explanations" of human thinking, feeling and behaviour", Phllosophy of the Soelal Scliences, 6(1976), 15-34; P.H. Klopfer en J.P. Hailman, An introduclion to anlimal behaviour; ethology's first century, Londen 1967; A. Nisbett, Konrad Lorenz, Londen 1976; R.J. Richards, The innate and the learned: evolution of Konrad Lorenz's theory of instinct", Phillosophy" of the Soclall Sciences, 4(1974), 111-133; W.I. Thorpe, The origins and rise of ethology: Londen 1979.

8 Vergelijk J. R. Durant, op. cit. noot 7.

9 Zie G. $\mathbb{E}$. Allen, "Naturalists and experimentalists: the genotype and the phenotype", in: W. Coleman en C. Limogenes (red.), Studies in the history of bilology "Baltimore 1979, 179-209.

10. Voor Danwins jdeeen over gedrag en de geest, zie R.J. Richards, Darwim and the emergence of evolutionary theories of mind and behavior, Chicago 1987, en $D$. Kohn(red.), The Danulnian heritage, Princeton 1985 , vootral de bijöragen van J. Browne (hoofdstuk 12) en R.W. Burkhardt (hoordstuk 13).

11 Zie D.E. Allen, The naturalists in Britain. Hatmondsworth 1978, $2 \mathrm{e} \mathrm{dr.}$

12 Zie N. Tinbergen, 'An objectivistic study of the innate behaviour of animals', Btbllotheca Blotheoretica, 1(1942), 39-98.

13 Relevante artikelen en boeken zijn J.B. Watson, "Psychology as the behaviou rist views it", Psychological Review, 20(1913), 158-178; J.B. Watson, Psychology from the stundpoint of a behaviourist, Philadelphia $1919 ; \mathrm{K}$. Lorenz, 'Beobachtungen an Dohlen', Jourmal für Ornithologite, 75(1927), 511-519; K. Lorenz, 'Uber die Bildung des Instinktbegriffes', Die Naturwissenschaften, 2S(1937), 1899.331 ; K. Lorem $z_{7}$ 'Uber den Begriff der Instinkthandlung', Folio Blotheoretlica, 2(1937), 17-50; K. Loren , 'Inductive und teleologische Psychologie', Die Naturwilssensehafte n, 30(1942), 133-143.

14 Een vollediglijst van Kuo's publicaties is te vinden in Z-Y Kuo, The dynamles of behavlor development; an epigenetic view, New York 1967.

15 B. Mackenzie, op. cit. noot 4.

16 Zie D.L. Krantz en D. Allen, "The rise and fall of McDougall's instinct doctrine" Journal for the History of the Behaviourni Sciences, 3(1967), 326-338,

$17 \mathrm{Z}-\mathrm{Y}$. Kuo, "The net result of the athti-heredity movement in psychology", Psychologleal Review, 36(1929), p. 183 c.v.

18 Zie Z-Y.Kuo, op. cit., noot 17, p. 196-197. Nadat Kuo hell werk van de neuro-embryoloog Coghill heeft gelezen, is er een kleine kentering op dil punt te bespeuren. Vergelijk hiervoor Z-Y. Kuo, "Ontogeny of embryonic behavior in Aves: III, structural and environmental factors in embryonic behavior', Journal of Comparatlive Psychology, 13(1932), p. 265

19 Onder andere Camichael, Cruze, Maier en Schneirla. Carmichael is in dit rijtje belangrijk, omdat hij de standaardinleiding in de gedragsembyologie verzorgde. Vergelijk $\mathbf{L}$. Carmichael, Manual or child psychology, New York 1946 , en L Carmichael, The onset and early development of behavior', in: P.H. Mussen(red.), Carmichacl's manunl of child psychology, vol. 1, New York 1970, $447-563$.

20 Vergelijk F.A. Beach, "The snark was a Bojuum", American Psychologist, 5(19S0), 115-124.

$21 \mathrm{~K}$ Lorenz, The compatative method in studying innate behaviour patierns", Symposia of the Society for Experimental Blology, 4(1950), p. 239-240. 
22 De theoretische veronderstellingen in de ethologische theorie waren tot dat toe ongewijzigd gebleven: wergelijk bijyoorbeeld het bekende overzichtswerk van $\mathbb{N}$. Tinbergen, The study of lnistine, Oxford 1951 . Wel hadden ethologen hun ideeën over soortspecifieke, aangeboren gedragspat ronen gepreciseerd. Een woorbeeld is het onderzoek van Lorenz en Tinbergen raar de elrolbeweging wan de gans. Met de eirolbeweging bestaande uit het uitstrekken vam de hals, helt brengen van de snavel achter een wit het nest gerold ei, wordt het $\mathrm{ei}$, in koers gehouden door de balancerende zijdelingse bewegingen van de snavel, weer in het nest teruggebracht. Lorenz en "Tinbergen haalden het ei halwerwege de intrekbeweging weg. Dit had als gewolg dat de zijdelingse bewegingen stopten, maar wormde geen beletsel voor het wolledig a maken van de intrekbeweging Aangezien de intrekbeweging steeds een vast pat roon had, werd geconcludeerd dat het een aangeboren gedragspatroon was. Zie $\mathrm{K}$. Lorenz en N. Tinbergen, Taxis und Instinkthandlung in der Eirollbeweging der Graugans', Zelischrift rîr 'T lerpsychologle, 2(1938), 1-29.

23 D.S. Lehrman, 'A critique of Konrad Lorenz's theory of instinctive behaviour', The Quarterly Revilew of Biology, 28(1953), p. 341 e.v.

24 D.S. Lehrman, op. cit, noot 23, p. 342 .

25 Een witzondering hierop is Thorpe, een fervent aanhanger van Lorenz; zie bijwoorbeeld W.H. Thorpe, Learning and Insilinet tn animals, Cambridge 1963 , $2 e$ dr., p. 346 e.v.

26 K. Lorenz, Evolution and modiflcation of behavior, Chicago 1965, p. 23-24. Voor een debat tussen Lorenz, Schneirla en Lehrman, zje P.P.Grassé (red.), L'instinct dans le comportement des animaux et de l'homme, Parijs 1956.

27 I. Eibl-Eibesfeldt, "The interactions of unlearned behaviour patterns and learning in mammals", in: J.F. Delafresnaye(red.), Brain mechanisms and learning, ClOMS Symposium, Oxford 1961, p. 70.

28 D.S. Lehrman, "Semantic and conceptual issues in the nature-nurture problem", in: L.R.

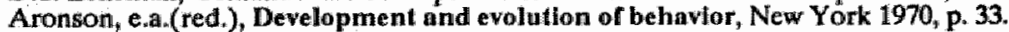

29 D.S. Lehrman, op. cit., noot 23 , p. 344.

30. Subcontraire begrippen zijn te onderscheiden als men uitgaat van de veljunctie('of...of, of beide'). Gaat men uit van de autjunctie('of...of, maar niet beide'), dan zijin alleen contraire en contradictoire begrippen te onderscheiden. Voor een uiteenzetting van deze elementaire logica, E.M. Barth, "Enten-Eller" de logica van licht en donker', Algemeen Nederlands Tijdschrift voor Wijsbegeerte, 61(1970), 217-240. In dit geval is dus het begrippenpaar 'aangeboren-aangeleerd' een voorbeeld van onderling contradictoire begrippen; het begrippenpaar 'instinctief-geconditionecrd' een voorbeeld van onderling contraire begrippen, en 'rijping-ervaring' een voorbeeld van een subcontrair begrippenpaar.

31 K Lorenz, op. cit., noot 26 , p. $43-44$.

32 D.S. Lehrman, op. cit., noot 28 , p. 31 .

33. Vergelijk D.S. Lerhman, op. cit,, noot 28; zie ook J.P. Kruyt, 'Ontogenie en gedrag', in: G.P. Baerendls(red.), Ethologie; de blologle van gedrag, Wageningen 1973, 158-181.

34 R.A. Hinde, Animal behaviour: a synthesis of ethology and comparative psychology, New York $1970,2 \mathrm{e}$ dr., p. 444 e.v.

35 N. Tinbergen, 'On aims and methods of ethology', Zeitschrift für Tierspychologie, 20(1963), 410-433. Vermeld moet worden dat Tinbergen het onderzoek van Kuo niet bespreekt.

36 D.S. Lehrman, op cit., noot 28.

$37 \mathrm{Z} \times \mathrm{Y}$. Kuo, op. cit., noot 14, p. ix. Het voorwoord tot dit boek bevat autobiografische notities. Vergelijk cok G. Gottlieb, 'Zing-Yang Kwo: radical scientific philosopher and innovative experimentalist(1898-1970)', Journal of Comparative and Phystological Psychology, 80(1972), 1-10.

38. Overzichten van het werk van Coghill en Windle zijn G.E. Coghill, Anatomy and the problem of behavior, Cambridge 1929, en W.F. Windle, Physiology of the retus; origins and extent of functlon In prenatal Ule, Philadelphia 1940.

39 V. Hamburger, 'Some aspects of the embryology of behavior', The Quarterly Review of Blology, 38(1963), 342-365.

40 K. Lorenz, "Uber den Begriff der Instinkthandlung', Follo Biotheorelica, 2(1937), 17-50.

41 V. Hamburger, op. cit.., noot 39 , p. 363.

42 V. Hamburger, op. cit., noot 39 , p. 343.

43 Van belang zijn . Hamburger, op. cit., noot 39; V. Hamburger en M. Balaban, 'Observations and experiments on spontaneous rhythmical behavior in the chick embryo",

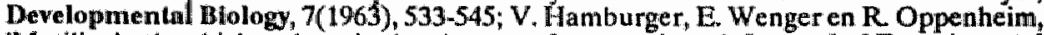
"Motility in the chick embryo in the absence of sensory input', Journal of Exper/mental Zoology, 162(1966), 133-160.

44 G. Gottlieb en Z-Y. Kuo, 'Development of behavior in the duck embryo', Journal of Comparative and Physlological Psychology, 59(1965), 183-188.

45 G. Gottlieb en Z-Y. Kuo, op. cit., noot $44_{\text {in }}$ p. 188. 
$46 \mathrm{R}$. Oppenheim, "Amnion contractions and embryonic bellavior in the chick embryo", Science, $152(1966), 528-529$.

47 V.Hamburger, E. Wenger en R. Oppenhein, op. cit, noot 43, p. 151.

$48 \mathrm{Z}-\mathrm{Y}$. Kuo, op. cit., noot 14, p. 47. Vergelijk oolk Oppenheims bespreking van (en kritiek op) Kuo"s boek in The Quarterly Review of IBtology, 52(1971), 327-328.

$49 \mathbb{R}$. Oppenheim, 'Embryology of behavior in birds; a critical review of the role of sensory stimulation in embryonic movement', in: K.H. Voous(red.), Proceedings of the xwth International Ornilihological Congress, Leiden 1972, p. 293.

So Volgens Oppenheim zijn Kuo's ideeën beinvloed door een "Zeitgeist", zie R. Oppenheim, 'Preformation and epigenesis in the origins of the nervous system and behaviors issues, concepts, and their history', in: P.P.G. Bateson en P.H. Klopfer(red.), Perspectives in ethology, vol 5, New York 1982, 1-100. Dit artikel is een staaltje wan wat Butterfield "whig history heeft genoemd.

51 Lorenz zou het nooit zo hebben geformuleerd. Inprenting is volgens hem geen leerproces. Deze opvatting wordt onder andere bestreden door Skinner. Voor een overzicht wan de verschillende theorieën, P.P.G. Bateson, The characteristics and context of imprinting", Blologlcal Revlew, 41(1966), 177-220.

52 Van de vele publicaties van Gottlieb noem ik hier slechts G. Gottlieb, 'Prenatal behavior of birds', The Quarterly Review of Blology, 43(1968), 148-174; G. Gottlieb, Development of species Identincatlon, Chicago 1971. Dit boek geeft een overzicht van zijn werk tot 1972 .

53 Gottlieb heeft overigens de ethologische theorie van Lorenz bekritiseerd, zie G. Gotttieb, 'Early development of species-specific auditory perception in birds", in: G. Gottlieb(red.), Neural en behaviornl specifity; studies on the development of behavior and the nervonis system, vol. 3, New York 1976, 237-280. Lorenz heeft zijn theorie na 1965 nauwelijks meer veranderd; vergelijk K. Lorenz, Vergleichende Verhaltensforschung Grundiagen der Ethologie, Wenen 1978.

$54 \mathrm{~V}$. Hamburger, 'Anatomical and physiological basis of embryonic motility in birds and mammals", in: $G$. Gottlieb(red.), Behavloral embryology; studies on the development of behavlor and the nervous system, vol. 1, New York 1973, 51-76.

55 Het 'oprekken' en 'inperkem' van begrippen is door Lakatos geanalyseerd in de wiskunde; vergellik I. Lakatos, Proofs and refutations, Cambridge 1976 , uitgegeven onder redactie van J. Worrall en E. Zahar.

56 D.S. Lehrman, op. cit., noot 28.

57 J. McVicker Hunt, The psychological basis for using pre-school enrichement as an antidote for cultural deprivation'; in: E. D. Evans( 'red.), Chilldren; readings in behaviour and development, New York 1968, p. 481 e.v.

58 I. Eibl-Eibesfeldt, Grundrisse der Vergleitchende Verhaltensforschung, München 1967, p. 35 e.v.

59 Zie voor dit onderscheid L. Fleck, Entstehung und Entwicklung eliner wissenschafillchen Tatsache, Frankfurt 1980, hoofdstuk 4, par. 3 en 4. De eerste editie verscheen in 1935.

60 K. Immelman, G.W. Barlow, L. Petrinowich, M. Main(red.), Behavioral devellopment, Cambridge 1981, p. 6.

61 Vergelijk in dit verband ook S. Oyama, The ontogeny of Information, Cambridge 1985, die zich verbaast ower het feit dat onderzoekers regelmatig wervallen in de oude tegenstellingen. Ower bijvoorbeeld het interactionisme schrijt zij op p. 19: 'What strikes one is the relative slowness and internal confusion with which an interactionist perspective emerges, and its ability to coexist with its contradictions'. Ondat het interactionisme het resultaat is van puzzeloplossen, en dus blifft ingebed in de oudere perspectieven, is dit niet verbazingwekkend.

62 D.J. Haraway, Crystals, fabrics, and fields, Londen 1976, p. 204.

63 D.J. Haraway, op cit., noot 62, p. 205-206.

64 Voor het constructivisme in de moderne wetenschapssociologie, zie onder andere $\mathbf{B}$. Latour en S. Woolgar, Laboratory life; the social constiructlon of scientific facts, Princeton $19862 \mathrm{e}$ dr.; B. Latour, Sclence In action, Milton Keynes 1987; $\mathbf{S}$. Woolgar, Sclence, the very Idea, Londen 1988; H.M. Collins, Changing order, Londen 1985; K. Knorr-Cetina, The manufacture of knowledge, Oxford 1981; voor het Sterke Programma in de wetenschapssociologue, zie onder andere D. Bloor, Knowledge and soclial Imagery, Londen 1976; B. Barnes, Interests and the growth of knowledge, Londen 1977.

65 S. Shapin, 'History of science and its sociological reconstructions', History of Selence, $20(1982)$, p. 159.

66 S. Kripke, Naming and necessity, in: D. Davidson en G. Harman(red.), Semsantics of natural language, Dordrecht 1972, 253-355; H. Putnam, Mind, language and realliy, II, Cambridge 1975, vooral hoofdstuk 11 en 12 . Voor een kritick op de ideeên wan Kripke en Putnam, zie onder andere J. Dupré, 'Natural kinds and biological taxa', The Philosophical Review, XC, 1(1981), 66-90. Putnam heeft onlangs de realistische positie verlaten 
en verdedigi nu het intern-wealisme. Zie onder andere H. Putnam, Reason, truth and history, Cambridge 1981. Deze civergang wordf beschreven en geanalyserd door $I$. Hacking, hepresenthg and intervening. Cambridge 1983, hoofolstik 6 en 7 .

4

\section{Fenomenen en theorleên}

1 Voor cen interessante fiosofische analyse van de Kloof tussen de alledaagse en fysische wereld", zie P.M.S. Hacker, Appearanee and realily, Oxford 1987.

2 K.R Popper, Thie logie of scientific discowery Londen 1980, $10 \mathrm{de}$ dr, hoofdst uk 5

3 Voor een overzicht van de fllosotie van de Wiener Kreils, $V$. Kraft, Der Whener Kreis, Wenen 1950 , en J. Joergensen, The development of logical empiricism", Intermallonal Encyelopedia of Unined Sclence, vol. II no. 9, Chicago 1951, 1-90.

4 Vergelijk P.M.S. Hacker, Insight and Illusion, Oxford $1986,2 \mathrm{e}$ dr, hoofdstuk 5 , waarin de relaties tussen de idecën van Witgenstein en die van de Wiener Kreis worden bespiroken. Zie cok G.P. Baker, Whitgensteln, Frege and the Vlenna Circle, Oxford 1988.

5 Deze ontwikkeling wordt uitvoerig beschreven en geanalyseerd door G.P. Baker en P.M.S. Macker, "Witigenstein and the Vienna Circle" the exaltation and deposition of ostensive definition, Teoria, 2(1985), 5-33.

6 R. Carnap, Der loglsehe Authau der Welt, Wenen 1928, p. 16.

7 KR. Popper, op. cit., noot 2 , hoofdstuk 3 en appendix * $x$.

8 Mijn weergave van Wittgensteins filosofische ideeen is gebaseerd op het werk van Baker en Hacker. Vergelijk G.P. Baker en P.M.S. Hacker, Wittgensteln; meaning and understanding, Oxford $1983,2 \mathrm{e}$ dr. G.P. Baker en P.M.S. Hacker, Wittgenstein's phllosophical investigallons, Oxford $1983,2 e \mathrm{dr}$. G.P. Baker en P.M.S. Hacker, Wittgenstein; rules, grammar and necessily, Oxford 1985; G.P. Baker en P.M.S. Hacker, Seepticism, rules and language, Oxford 1984 (dit werk is een kritiek op S. Kripke, Witgenstein on rules and privale language, Haward 1982); G.P. Baker en P.M.S. Hacker, Language, sense, and nonsense, Oxford 1984; P.M.S. Hacker, 1986, op. cut , noot 4; en G.P. Baker, 1988, op. cit., noot 4 .

9 L. Wittgenstein, Tractatus Logico-Phllosophicus, Londen, 1981, herdruk van de tweetalige uitgave uit 1922, en L. Wittgenstein, Pliflosophische Untersuchungen, Frankfurt $1982,3 \mathrm{e}$ dr.

10 Zie P.M.S. Hacker, op. cit., noot 4, hoofdstuk 3, par. 2.

11 L. Wittgenstein, TLP, op. cit, noot 9, 3.263, en het comemtarar op deze paragraaf: $L$. Wittgenstein, Philosophische Bemerkungen, Frankfurt 1984, $2 \mathrm{e} \mathrm{dr}$., p. 54.

12 B.F. McGuiness(ted.), Witgenstein und der Wiener Kreis, "Schriften 3', Suhrkamp 1967, p. 209-210.

13 Voor een uitvoerige argumentatie, G.P. Baker en P.M.S. Hacker, Wiltgenstein; meaning en understanding, Oxford $1983,2 \mathrm{e} \mathrm{dr}$, hoofdstuk 5 .

14 Deze paragraaf is wooral gebaseerd op, P.M.S. Hacker, The rise and fall of the picture theory, in: 1. Block (red.), Perspectlves on the philosophy oll Witigenstein, Oxford 1981, 85.109; G.P. Baker en P.M.S. Hacker, Wilgenstein; rules, grammar and necessilly, Oxford 1985, en P.M.S. Hacker, Insight and IIlusion, Oxford 1986, wweede, herziene druk, hoolidstuk 7 .

15 Zse voor een analyse P.M.S. Hacker, op. cil., noot 4, hoofdstuk 3 en 4.

16 L Wittgenstein, IThosophische Grammatk. Frankfurt 1978, 2 e druk, p. 200.

17 Wittgenstein, Mhllosophische Bemerkungen, Frankfurt $1984,2 \mathrm{e}$ dr., par. 7.

18 Zie P.M.S. Hacker, 1986, op. cit., noot 4, p. 188.

19 Voor het onde rscheid tussen ontwikkelingen op lokaal en globaal niveau, zie G. de Vries, "De ontwikkeling van wetenschappelijke keminis; sociologisch beschouwd", Kennis en Methode, 6(1982), 190-220; L. Boon, De list der wetenschnp, Baarn 1983, vooral hoofd. stuk 3; en H. Smit, Evolutle en matuurlijke selectle epistenologle, eindvers lag project 8314, Nijmegen 1985.

20 Voor Wht tgensteins sanple-begrip, zie G.P. Baker en P.M.S. Hacker, op. cit., noot 12, p. $102 \mathrm{ev}$.

21 G.P. Baker en P.M.S. Hacker, op. cit, noot $12^{*}$ p. 107 e.v.

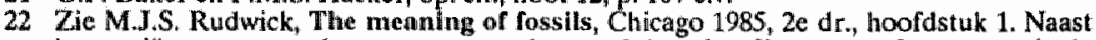
het copieren en reproduceren van samples spectt het visualliseren van fenomenen in de inductieve stijl een belangrijke rol. Zie onder andere M.I.S. Rudwick, The emergence of a visual language for geological science 1760-1840, IIlstory of Sclience, 14(1976), 149.195, en B. Latour, 'Visualization and Cognition: thinking with eyes and hands', Knowledge and Soclety, Siudies in the Soclology of Culture Pust and Present, $6(1986)$, 1-40; B. L \& tour, Sclence In actlon, Milton Keynes 1987, wooral hoofdstuk, 6; en S. Alpers, The art of describing, Londen 1983 . Bij het visualiseren van fenomenen maakt men 
gebruik van bepaalde projectie-methoden die kwnten worden gecorngeend, gekritiseerd, etcetera, onder verwijzing nar de gebruikte representatic-conwenties. Vergelijk in dii verband Wittgensteins latere visie op projectie-nethoden, besproken en geandysederd door P.M.S. Hacker, 1981, op. cili., noot 14.

23 Vergelijk bijvoorbeeld M.T Ghiselin, The triumph af the Darwhtan method, Chicago 1969, hoofdstuk 4.

24 B. Latour, 1987 , op. cit. noot 22 , hoolidstuk 6.

$25 \mathrm{Zie}$ S. Connor en S. Kingman, The search for the virus, Londen 1988 , hoofdstuk 3 en 4.

26 Vergelijk P.M.S. Hacker, 1986, op. cit. noot 4, p. 206 ev.

27 Zie P.M.S. Hacker, 1986, op. cit. noat 4, 209-210. Vergelijk in dit verband ook S. Shapin en S. Schaffer, Leviathan and the airpump, Princeton 1985, watin de opkomst van. wat zjj noemen - "virtual wittnessing" als nieuwe methodologische praktijk in de $17 \mathrm{e}$ eeuw wordt geanalyseerd.

28 T.S. Kuhn, The structure of scientific revolutlons, Chicago $1970,2 \mathrm{e} \mathrm{dr}$, hoofdstuk 3 en 4.

29 T.S. Kuhn, op. cit, noot 28 , p. 188.

30 N. Tinbergen, Het dier In zun wereld, deel 1, veldonderzoek, Utrecht 1976 , hoofdstuk 6.

31 N. Tinbergen, op. cit., noot 30, p. $231-232$.

32 L. Wittgenstein, Philosophisehe Untersuchungen, Frankfurt 1982, $3 \mathrm{e}$ dr., par. 281. Zie ook P.M.S. Hacker, Appearance and reality, Oxford 1987, p. 18 e.v.

33 M. Heidelberge $r_{n}$ 'Chemical aspects of the precipitin and agglutinin reactions", Chemical Reviews, 24(1939), 323-343.

34. L. Pauling, 'A theory of the structura and process of formation of antibodies', Journal of the Amerlicain Chemical Society, 62(1940), 2643-2657.

35 L. Pauling, D. Pressman en A.L. Grossberg, The serological properties of simple substances; V1I;, Journal of the American Cliemical Soclety, 66(1944), pp. 785-786.

36 Vergelijk onder andere F.M. Burnet en M.D. Fenmer, The produclion of antibodites, Melbourne $1949,2 \mathrm{e}$ dr.

37 Zie voor eerdere discussies over de aard van de antigeen-antilichaam binding, P.M.H. Mazumdar, The antigen-antibody reaction and the physics and chemistry of life", BulletIn of the History of Medicin 48 (1974), 1-21, en L.P. Rubin, 'Styles in scientific explanam tion: Paul Ehrlich and Svante Arrhenius on inmunochemistry "Journal of the History of Medicin, 35(1980), 397-425.

38 B̈jvoorbeeld het onderzoek van Glenny en zijn medewerkers, waarin het aviditeitsbegrip centraal stond; zie onder andere A.T. Glenny, G.C. Pope en H. Waddington, The measurement of the combining power of Diphteria toxim and toxoid with antitoxin in relation to their antigenic efficacy," Journal of Pathology and Bacterfology, 28(1925), 279-303, en M. Barr, The role of test toxins and the need for standards in the determination of avidity of antitoxins', Journal of Pathology and Bacteriology, 56(1949), 85-91.

39 N.K Jerne, A study of avidity, Kopenhagen 1951.

40 N.K. Jerne, The natural selection theory of antibody production", Proceedings of the National Academy of Science, $41(1955), 849-857$.

\section{5 \\ Soclioblologle}

1 E.O. Wilson, Socioblology; the new synthesis, Cambridge 1975. Wilsons bock vormit dus eerder thet eindpunt dan hei begin van de sociobiologische onderzoekstraditie. In zijn overzichtsartikel formuleert van Rhijn het als volgt: "Ik zal daabij niet beginnen en eindigen bij Wilson, want de richting is ouder (behalwe de naam) en heeft zich inmiddels: verder ontwikkeld". J.G. wan Rhijn, "Sociobiologie; drijkrachten wan de evolutie wan sociaal gedrag", in: G.P. Baerends(red.), Elhologle, de blologle ran gedrag, Wageningen $1981,2 \mathrm{e}$ dr., p. 289

2 P. Bateson, Behavioural development en evolutionary processes", in: King's College group(red.), Current problemis in socloblology, Cambridge 1982, p. 133

3 P. Bateson, op. cit., noot 3, p. 135.

4 Zie L. Boon, De list de wetenschnp, Baarn 1983, p. 52 e.v.

5 Voor het verschill tussen ulitmate-causale theorice m en proximate-causale theorieên, zic E. Mayr, 'Cause and effect in biology', Science, 134(1961), 1501-1506.

6 C.S. Pittendrigh, "Adaptation, natural selection and behaviour', in: A. Roe en G.G. Simpson(red.), Behavior and evolution, New 1 laven $1958,390-416$.

7 G.R de Beer, Embryalogy and evolution, Oxford 1930.

8 Vergelijk hiervoor S.J. Giould, Ontogeny and phyllogeny, Cambridge 1977.

9 Sinds kort wordt er weer meer aandacht besteed aan de relatie tussen fylogenie en embryologie, zowel inistorisch als theoretisch. Wergelijk onder andere TJ. Horder, J.A. 


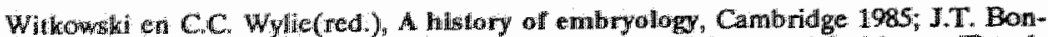

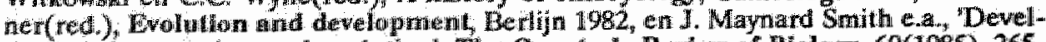

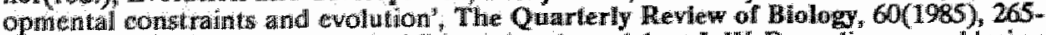
287. Een belangrike theoret ische bijurage is geleverd door L.W. Bus, die een verklaring heeft onthikeld woor de wier-door Gould onderscheiden - klasisen wan "heterochronie", wit de tegengestelde "belangen" wan cellen en individuen. Zie L.W. Buss, The Evoluthon of Indwiduallfy, Princeton 1987.

10 Van belang zin R.H. MacA Arthur, "Ecological consequences of natural selection", in: T.M. Watteman en MJ. Morowitz(ted.), Theoretical en mathematical blology, New York 1965,389-397, en K. H. Mac Arthur en E.R Pianka. The optimal use of a patchy ervinomment "The Amerilcan Nathuralist 100(1966), 603-609. Voor en rewiew van de optimalisatie heorie, zie G.H, Byke, HR Pulliw on E. L. Chatnow, 'Optimal foraging a selective rewiew of theory and tests", The Quarterly Rewiew of Blolog, $52(1977), 137-154$. Voor de bistorische achtergronden wan MacArthun onderzote $k$, zie $S$. Kingsland, Modelling natrure eplsodes in the history of population ecology, Chicago $1985^{3}$, voorall hoofdstuk 8. Kingsland bespreckt echter niet de optimalisatie theorie van MacArthur. MacArthurs mathematische beradering in de oecologie wordt kort besproken door S.D. Fretwell, The impact of Rotert MacArthur on ecology", Annual Review of Ecology and Systema(les, $6(1975), 1113$.

11. D. Lack, The natural regulation of animal numbers, Oxford 1954; en D. Lack, Ecologlcall adnptatlons for breeding In birds; I.anden 1968.

12 Voor cen overaichtswerk, zie $J$. Maynard Smith, Evolution and the theory of games, Cambridge 1982. In zifn artikel 'In Maldane's footsteps", in: D.A. Dewsbury(red.), Leaders fru the situdy of anlmul behavior, Londen 1985, 347-354, heeft Maynard Smith de achtergronden van de speltheorie uiteengezet.

13 I. Maynard Smith en C.R. price, "The logic of animal conflicts", Nature, 246(1973), 15-18.

14 ji. Maynard: Smith en G.A. Parker, "The logic of asymmetric contests", Animal Behaviour, $24(1976), 159.175$.

15 In de speltheoretische redunering is het eenwoudiger om genen op te vatten als de eenheden van evolutie. Daa ruit volgt natuurlijk niet dat dexe gedachte niet kritiseerbaar is. $Z$ ij veronderstelt bijwoorbeeld Weismanns 'germ-soma barrier", maar problemat iseert Weismanns theorie nict. Ten onrechte volgens sommigen; vergelijk bijvoorbeeld de recente kritiek wan L.W. Buss, op. cit., noot 8, met name p. 169-197. Buss verklaart de 'germ-soma barrier" als een nieuw stadium in de evolutie vanuit de tegengestelde 'belangen' wan cellen en individuen. Buss geeft een evolutionair-historische verklaring, lerwijl in de speltheorieên de 'verwijzing' naar het historische evolutieproces ontbreekit.

16 I. Lakatos, "Falsification and the methodology of scientifie research programmes', in J. Worall en G. Currie(red.), The methodology of sclentiric resenreh programmes, 'Philosophical papers; deel 1, Cambridge 1978, p. 51 . Voor Lakatosiaanse analyses van wiskundig georiènteerde theorieen, zie C. Mowson(red.), Method and appraisal in the playsical sciences, Cambridge 1976.

17 Voor een uitvoerige argumentatie, H. Smit, 'Ethologic en de mens als paradigma', te verschijnen.

18 Zie onder andere, K. Bühler, Die Krise der Psychologie, Jena 1927.

19 Zie onder andere, N. Tinbergen, "Derived activities; their causation, biological significance, origin, and emancipation during evolution" "The Quarterly Revlew of Blology, $27(1952), 1-32$. Voor een review wan de conflicthypothese, zic G.P. Baerends, An evaluation of the conflict hypothesis as an explanatory princlple for the evolution of displays ${ }_{4}$ in: G.P. Buerends, C. Beer en A. Manning(red.), Function and evolution in bethitlowis, Oxford $1975,187-227$.

20 A.M. Manning; An Introductlon to animall bethaviour, Londen 1972, 2e dr, p. 108-109.

21. A.W. Stokes, "Agonistic behaviour among blue tits all winter feeding station", Behaviour, 19(1962), 118-138; A.W. Stokes, The comparatiwe ethology of great, blue, marsh and coal tits at a winter feeding station ${ }^{*}$ Behaviour, 19(1962), 208-218; W.D. Dunham, "Agonistic behaviour in captive rose-breasted grosbeaks', Behaviour, 27(1966), 160-173; M. Anderssom, 'Social behaviour and communication in the great skua', Behaviour, $58(1976), 40-77$.

22 Vergelijk bijwoorbeeld K. Lorenz, On agression, New York 1966, p. 38, en V.C. Wynne Edwards, Amimal dispersilon in relation to social behaviour, Fdinburgh 1962.

23 G.C. Willians, Adapiation and natural selection, Princeton 1966; J. Maymard Smith, 'Group selection and kin selection', Natture, 201(1964), 1145-1147.

24 J Maynard Smith, op. cit., noot 12, p. 147.

25 J. Maynard Smith, The theory of games and the evolution of animal conflicts", Jourmal of Thearetleal Biology, 47(1974), $209-221$

26 R. Dawkins en J.R. Krebs, 'Animal signals: information or manipulation?', in: J.R. Krebs en N.B. Davies(red.), Behaviournl ecology, Oxford 1978, 282-389; en R. Dawkins en J.R. 
Krebs, "Animal signals: Mind-reading and manipulation: in: J.R. Krebs en N.B. Diavies(red.), Behravloural ecology, Oxford $1984,2 \mathrm{e}$ d, $380-402$.

27 P.G. Caryl, "Communication by agonistic displays: what can games theory contribute to ethology ?", Behaviour, $68(1979), 136-169$.

28. Vergelifk voor de verschillende manieren was op onderoekets met 'monsters' kumen omgaan 1. Lakatos, Prools and refulations, Cambridge 1976 , witgegeven onder redactie van J. Worrall en E Zahar.

29 R.A. Hinde 'Animal signalis: ethological and ganes-theory appiroaches are not incompatibel" Anilmal Behaviour, 29(1981), $535-542$.

30 R.A. Hinde, op cit noot 29, p. 537.

31 P.G. Caryl, "Animal signals" a reply to Hinde", Animal Behavlour, 30(1982), p. 241.

32 J.G. Van Rhijn en R Vodegel, being honest about one"s intentions: an volutionary stable strategy for animal conflicts', Journal of 'Theoretical Biolow, 85(1980), 623-641.

$33 \mathrm{R}$ Axelrod en W.D. Hamilton, "The evolution of cooperation" Sclence, 211(1981), 1390-1396.

34 Zie J.G. Van Rhijn, 'Communication by agonistic displays: a discussion', Beliaviour, 74(1980), 284-293; P.G. Caryl, "Telling the truth about intentions', Journal of Theoretical Blology, 97(1982), 679-689; en J. Maynard Smith, Do animals convey information about their intentions?", Journal of Theorettcal Biology, 97(1982), $1-5$.

35 Vergelijk onder andere, $D$. Paton en $\mathbf{P}_{*} \mathrm{G}_{4}$ Caryl, 'Communication by agonistic displays: 1. variation in information content between samples', Behaviour, 98 (1986) 213-239; D. Paton, "Communication by agonistic displays: 2. perceived information and the definition of agonistic displays', Behaviour, $99(1986)$ 157-175.

\section{6}

\section{Immunologle tussen structure en functio}

1 Vergelijk H.F. Judson., The eighth day of creation, London 1979, en R. Olby, The path to the dowble the litix, Londen 1974.

2. P. Ehrlich, "On immunity with special reference to cell life', Proceedings of the Royal Soclety of London, B $66(1900), 424-448$.

3 Vergelijk onder andere K. Landsteiner, Die Specifteilïli der serologischen Reaktion, Berlijn 1933 ; K. Landsteiner, The Specificity of serological renctlions, New York 1945 , $1962,2 \mathrm{edr}$.

4 F. Breinl en F. Haurowitz, "Chemische Untersuchungen des Präzipitates aus Hàmoglobin und anti-Hämoglobin Serum und Bennerkungen über die Natur der Antikörper" "llop* pe-Seyler's Zeitschrifi fir Physiologische Chemie, 192(1930), p. 54.

$5 \quad F$. Breinil en $\mathbb{F}$. Haurowitz, op. cit, noot $4,45-57$.

6 L. Pauling, 'A theory of the structure and process of formation of antibodies", Jourmal of the American Chemical Sochely, 62(1940), 2643-2657.

7 L. Pauling, op. cit. noot 6, p. 2643.

8 A. Rothen en K. Landsteiner, "Adsorption of antibodies by egg albumin', Scle nce, $90(1939), 65-66$.

9 R.R. Porter, "The hydrolysis of rabbit Y-globulin and antibodies with crystallin papain", Blochenical Journal, 73 (1959), $119 \cdot 126$.

10 Vergelijk onder andere $G$. Allen, Lile Selence In the twenthleth century, Cambrigge 1978, 2e dr, hoofdstuk 7; L. Boon, De list der welenschap, Batarn 1983, hoofoluk 5 .

11 Watson en Crick probeenden Palings methode le imlleren; vergelijk J.D. Watson, The dowble hellx. Middlesex $1970,2 \mathrm{e}$ dr., hoofdstuk 7, en D. Crick, what mad pursull, New York 1988, hoofdstuk S.

12 L. Pauling en D.H. Campell, The production of antibodies in vitro', Scticnce, 95(1942), 440-44, en L Paulingen D.H. Campell, The manufacture of antibodies in vit ro', Journal of Experimental Medicine, $76(1942), 211-220$.

13 Vergelijk onder andere F. Haurowitz, P. Schwerin en $S$. Tunc, The Mutual precipitation of proteins and azoproteins', Archives of Bloche mistry, 11(1946), 515-520.

14 A.B. Stavitsky, 'In vitro studies of the antibody response', Advances in Immunology, 1(1961), pp. 236-238.

15 Voor een owerzicht wam het onderzoek van Pauling c.S., D. Pressman en A.L. Grossberg The structural basis of antibody specincity, New York 1968.

16 F.M. Bumet, The production of ant blbodies, Melbourne 1941

17 F.M. Burnet, op. cit., noot 16, en F.M. Burnet en F. Fenner, The production of antibodites, Melbourne $1949,2 \mathrm{~d}$,

18 D. Talmage, 'Allergy and immunology', Annual Revlew of Medicline, $8(1957), 239.256$. 
R. D. Oren. "Iminunogenefic conseguences of wascular anastomoses between bowine twins", Sclence, $102(1945)$, 400401; RD. Owen, H.P. Davis en R. F. Morgan, "Quintuplet calwes and erythrochte mosucisn", The Jotumal of Heredify, 37(1947), $291-297$.

20 F.M. Dumet en F. Denmer 1949, op. eit. noot 17, p. 103.

21 P. B. Medavw, Memolr of thinkirig Radish, Oxfond 1986, p. 110 e.w.

22 P.D. Medawar, op. cit. noot 21, P. 133.

23 R.E. Billingham, C. Brent en P.B. Medawar, Actiwely acquired tolerance" of foreign cells: "Nature, $172(1953), 603-606$.

24 T.M. Burnet, Enzme, antigen wnd virus, Cambridge 1956.

25 F.M. Burnet, The impact on ideas of imnunolog" Cold Spring Harbior Symposium on Qunnilative Blology, 32(1967), p. 3

26 I.M. Burnet, op. cit. noot 25, p. 3 .

27 F.M. Bumet, Changing patterns; an atypteal autoblography, Melbourne, 1968, pp. 213-214.

28 F.M. Durnet, op. cilt noot 25 , p. 1 .

29 Vergelijk onder andere L.E. Kay, "Conceptual models and analytical tools: the biology of physicist Max Delbruek" Journal for the History of Biology, 18(1985), 207-246.

30 Brief aan de auteur d.d. 27 naart 1987.

31 N.K. Jerne, A study of nvidily, Kopemhagen 1951.

32 N.K. Jerne, The presence in normal serum of specific antibody against bacteriophage $T 4$ and its increase during the earliest stage of Immunization", Journal of Immumology, $76(1956), 209-216$

33 N.K. Jerne, The natural-selection theory of antibody formation'; Proceedings of the National Acardemy of Selence 41(1955), 849-857.

34 Vergelijk N.K. Ie rne, "The natural selection theory of antibody formation; ten years later", in: J. Cairns e.a.(ted.), Phage and the origins of molecular biology, Cold Spring Harbor 1966, 301-312. Zie ook C.M. Steimberg e.a. (red.), The Immune system; restschrift in honinor of Niels Jerme on the occasion of his 70th birthday, twee delen, Basel 1981, warin biografische artikelen zijn opgenomen.

35 F.M. Burnet, "A modification of Jerne's theory of antibody production using the concept of clonal selection", The Australlan Journal of Sclence, 20 (1957), 67-69; 1.M. Bumet, The clonal selection theory of acquilred inmunily, Nashwille $1.959 ; \mathrm{F}, \mathrm{M}$. Burnet, The integrity of the body, Cambridge 1963 ; en F.M. Burnet, Cellullar immumology, Melbourne 1969 .

36 Vergelijk onder andere P.M. Burnet, op. cit. noot 27, hoofdstuk 8 , en G.I. Ada en G. Nosisal, "The clonal selection theory", Selentic American, 257:2 (1987), 50-57.

37 G.J.V. Nossal en J. Lederberg, 'Antibody production by single cells', Natture, 181 (1958), 1419-1420.

$38 \mathrm{O}$. Mäkelä, The specificity of antibodies produced by single cells', Cold Spring Harbor Symposium on Quantitative Blology, 32(1967), 423-430.

39 I. Roitt, Essentlal Immunollogy, Oxford 1984, 4e dr. p. 93.

40 J. Lederberg, "Gemes and antibodies', Sclence, 129(1959), 1649-1653. Vergelijk ook F.M. Burnet, "The new approach to immunology", "The New England Journal of Medicine, $264(1961), 24-34$.

41 F. Haurowitz, "The evolution of sellective and inst ructive theories of antibody formation", in: Cold Spring Harbor symposilum on Qunatitative Bilology, 32(1967), p. 561 .

42 Vergelijk onder andere 1 . Heurowitz, The nechanism of the immunofogical response", Blologlcal Review, 27(1552), pp. 272-273; en F. I. Smith e.a., "Animo acid composition of four rabbit antibodies', Journal of Biological Chemistry, 214(1955), p. 206.

43 I. Haurowitz, op. cit noot $41, p .565$.

44 E.L. Smith e.4., op. cit., noot 42, 197-207; $\mathrm{S}$. Fleischer e.a." "Composition of antibodies against acidic and basic azoproteins', Archives of Blochemisiry, 92(1961), 329-333.

45 R.R. Porter, 'A chemical study of rabbit antiowalbumin', Bioclhemicall Journal, 46(1950), p. 473 .

46 M.E. Koshland en F.M. Englberger, "Differences in the amino acid composition of two purified antibodies from the same rabbit", Proceedings of the Nationnl Academy of Sclence, $50(1963), 61-68$

47 E. Haber, Recovery of antigenic specificity after denaturation and complete reduction of disulfides in a papain fragment of antibody". Proceedings of the National Academy of Sclience, 52(1964), 1099-1112, P.L. Whitncy an C. Tanford "Recovery of specific activity after complete unfolding and reduction of an antibody fragment', Proceedings of the Natlonal Academy of Sclence, 53(1965), 524-532.

48 F.H.C. Crick, 'On protein synthesis', Symposium of the Society of Experimental Biollo$\mathrm{By}_{1}, 12(1957), 138-163$. Voor de ontwikkeling vam het centrale dogma, zie $\mathbb{R}$. Olby, Francis Crick, DNA, and the centrall dogma', Daedahis, 99(1970), 938-987; cn H.F. Judson, op. cit. noot 1 , vooral hoofdstuk 6 . 
49 G.M. Edelman, "Dissociation of Y-globuline", Journal of the American Chemical Soclexty, $81(1959), 3155-3156$.

50 G.M. Edelman en J.A. Gally, The nature of Bence-Jones proteins; chemieal sinilanties to polypetide chains of myeloma globulins and nomal $\mathrm{Y}$-globulins" Journal of Expert memlal Medlicline, 116(1962), 207227.

51 N.K. Jerne, 'Waiting for the End', in: Cold Spring Tarbor Synpostum on Quantitative Biollogy, $32(1967)$, p. 592 .

52 Voor een overzicht van de verschillende theoriecn, M. Coln, The take-home lesson$1971^{\prime}$, Annals of the New York Academy of Sciences, 1900(1971), 529.584.

53 Vergelijk onder andere $S$. Tonegawa, "Somatic generation of antibody diversity" Nature, $302(1983), 575-581$

54 N.K. Jerne, op. cit., noot 51 , p. 591.

55 Voor het creêren van fenomenen in de fysica, zie 1 . Hacking; Representing and intervening, Cambridge 1983, met name hoofdstuk 13.

\section{7 \\ Aanleg, omgeving en gedrag}

1 Vergelijk het voorwoord van Konrad Lonenz bi C. Darwin, The expresslon of the emotions in man and animals, witgave van de editie uit 1872 , Chicago 1965 , ix-xiil.

2 J.A.R.A.M. Van. Hooff, "A comparative approach to the phylogeny of laughter and smilling", in: R.A. Hinde(red.), Non verbal communication, Cambridge 1972, 209-241.

3 Voor een uitgebreide argumentatie H. Smit, "Ethologie en de mens als paradigma" "te verschijnen.

4 N. Timbergen, "On war and peace in animals and man", Sclence, 160(1968), 1411-1418.

5 N. Timbergen, op. cit, noot 4, p. 1415.

6 N. Timbergen, op. cit, noot 4, p. 1415.

7 Zie $R$ Axelrod, The evolution of cooperatlom, New York 1984.

8 R. Axelrod, op, cit, noot 7, hoofdstuk 4.

9 Zie G.P. Baker en P.M.S. Hacker, "The grammar of psychology: Wittgenstein's Bemerkungen über die Philosophie der Psychologie', Language and Commumication, 2(1982), $227-244$

10 Vergelijk L. Wittgenstein, Bemerkungen uber dle Phillosophle der Psychologie, 'Band

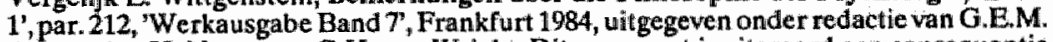
Anscombe, H. Nyman en G.H. von Wright. Dit argument is uiteraard een consequentie van het "private language argument". Voor een analyse van het "private language argument', zie P.M.S. Hacker, Insight and llision, Oxford 1986, $2 \mathrm{e}$, herziene druk, hoofdstuk 9.

11 Voor een analyse van de werschillende 'logische ruimtes' van deze, en andere, psychologische begrippen, zie G.P. Baker en P.M.S. Hacker, op, cit. noot 9.

12 W. Köhler, the mentality of apes, New York 1925.

13 EL. Thorndike, Animal intelligence, New York 1911.

14 H. Ebbinghaus, Uber das Gedächtnis, Leipzig 1885, en F.C. Bartlett, Remembering, Cambridge 1932 .

15 Zie bijvoorbeeld A.D. Baddeley, The psychology of memory, New York 1976.

16 Voor het regelbegrip, zie onder andere G.P. Baker en P.M.S. Hacker, Language, sense and nonsense, Oxford 1984 , hoofdstuk 7 .

17 Voor een analyse van de "interne' relaties tussen regelis en gedrag zule G.P. Baketr en P.M.S. Hacker, op. cit. noot 16, en G.P. Baker en P.M.S, Hacker, Sccepticlism, rules and languinge, Oxford 1984 , p. 92 e.v.

18 Zie L. Boon, Geschiedenis van de psychollogle, Meppel 1982, p. 133-151; en L. Bown De list der welenschnp, Baarn 1983, p. $77 \mathrm{e} . \mathrm{v}_{\text {. }}$

19 Vergelijk L.J. Cronbach, "The two disciplines of scientific psychology", "The American Psychologists, 12(1957), 671-684.

20 Zje onder andere $\mathbf{P}$. Medawar, 'Unnatural science', in: $\mathbb{P}$. Medawar, Plinto's republic, Oxford 1984, 167-183; en S. Rose, L..J. Kamin en R.C. Lewontin, Not in our genes, Middlesex 1984 , hoordst wik 5.

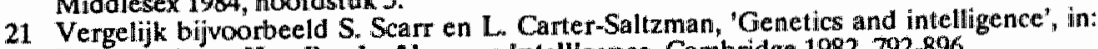
R. Sternberg, Handbook of human lntelligence, Cambridge 1982, $792-896$.

22 D. Paul, "Textbook treatments of the genetics of intelligence, The Quarterly Review of Blology, 60(1985), 317-326.

23 Voor analyses van de IQ-debatten, zie onder andere: H. Cravens, The trlumph of evolution, the heredity-environment controversy 1900-1941, Baltimore 1988, $2 \mathrm{edr}$." $\mathrm{NJ}$. Block en G. Dworkin, The IQ controversy, New York 1976; P. Urbach, "Progress and degeneration in the "IQ debate ${ }^{\text {*t" }}$, Brilish Journal of the Philosophy of Sclence, $25(1974)$, 


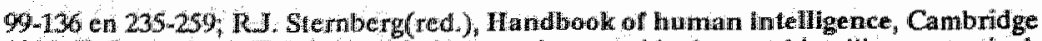

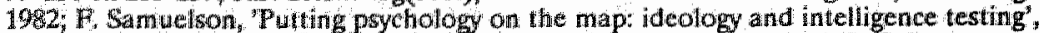
in: A. Buss(red.), Psychology In sochil eontext, New York 1979, 103-168; F. Samuelson, "World war I inteligence testing and the development of psycholog" Journal for the

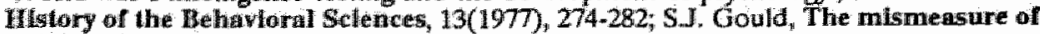
$\operatorname{man}_{3}$ Middlesex 1981 .

24 Zie 3. Harwood, "Heredity, erwiromment, and the legitimation of social policy", in: $\mathbf{B}$. Bames en $\$$. Shapin(red.), Natural arder; historical studes of scientific culture, Londen $1979,231-251$, wooral p. $235-236$

25 A R Jencen "How much can we boost 10 and scholastic achievement?" Harvard Educational Tevew, 39(1969), 1-123.

26 J. Hanwood, Nature, murture and politics: a critique of convent ial wisdom", in: J.V. Smith en D. Hamilion(red), The meritocratic intellect: studies in the history of educational research, Aberdeen 1980, 115-129.

27 J. Harwood, op. cil, noot 26, p. 121.

282 Lie bijvoorberid J. Harwood, op cit noot 24 , en 1 . Harbers, Soclalle wetenschappen en hun specllrulimie, Groningen 1986.

29 I. Harwood, op. cit, noot 24 , en vooral $\mathrm{H}$. Harbers, op. cit., noot 28.

\section{8}

\section{Controversiële problemen, oplosbare puzzels}

1 Vergelijk bijvoorbeeld S. Oyama, The ontogeny of Informswlon, Cambridge 1985, waarin wordt gepoogd een ondubbelzinnig antwoord op het aanleg-omgeving vraagstuk te formuleren. Aanleg- en Ongevingtheorieëm worden door haar op grond van hun metaforisch, speculatief gehalte afgewezen, in de veronderstelling dal het aanleg-omgeving op het niveau van de feiten op te lossen is.

2 N.K Jerne, 'Antibodies and learning: selection versus instruction', in G.C. Quartion e.a.(red.), The meurosciences: a study program, New York 1967, 200-205; en P. en J. Medawar, The life selence, New York 1977, hoofdstuk 13 .

3 F. Jacob, Bedld van binnen, Amsterdam 1989, p. 319 . Nederlandse ve rtaling van La statue Intérleure, Parijs 1987.

4 F.H.C. Crick, "On protein synthesis", Symposium of the Saciety of Experimentall Bilolowy, 12(1957), 138-163.

5 Zie bijwoorbeeld \$. Rose, L.J. Kamin en R.C. Lewontin, Nal in our genes, Middlesex 1984.

6 Zie L. Boon en H. Smit, 'Research styles and the reception of sociobiology', Philosophy of the Soclial Sciences, 19(1989), $19-40$.

7 K.R. Popper, Objective knowledge, Oxford 1979, 2e dr., p. 122.

8 L. Wittgenstein, Vermischte Bemerkungen, un: 'Werkausgabe Band 8', Frankfurt 1984, P. 471 . 


\section{Verklarende woordenlijst}

In deze lijst is een korte omshrijwing gegeven wan een aantal in wit boel gebruikte termen en uitdrukkingen. Het betreft technische termen en witdrukkitigen wit de levenswetenschappen en elementaire begrippen uit de wetenschapstheorie. Wamneer een sterretje voor een woord staat, dan wordt dat woord elders in deze woordenlijst omschreven.

Admptalle, ampassing Verandering in de eigenschappen van een organisme waardoor het organisme een grotere overlevingskans heeft in een bepaalde omgeving.

Adaptlef enymm * Enzym dat wordt gesynthet iseerd in de aanwezigheid van een bepaalde stof Bijwoorbeeld de bacterie Escherichia coll maakt het enzym B-galactosidase alleen aan in de aanwezigheid van lactose.

Ad hoc verandering Een wijziging in een theorie waatbij de oorspronkelijke theorie wordt aangepast zonder dat die aanpassing tot de voorspelling van nieuwe feiten leidt.

Amnltelt Een maat voor de bindingskracht tussen een antigeen en een "antilichuam. Deze mat wordt meestal afgeleid uit de associatie-constante van de interactie.

Afweersysteem Systeem waarmee een organisme zich kan wapenen tegen onder andere infectieziekten. Het systeem bestaat uit een specifieke afweer, dat via antilichaam-productie werkt, en een niet-specifieke afweer, waarbij cellen betrokken zijn. Vergelijk immuniteit.

Agglutinatle Proces waarbij cellen of bacterièn samenklonteren als de "antigenen op die celien of bacterien een interactie aangaan met "antilichamen. De antillichamen vormen hierbij een brug tussen de antigenen van verschillende cellen.

Alpha hellx Een regelmatige, rechtsdraaiende spiraalvormige structwur van (poly-) "peptide ketens. De helix ontleent haar stabiliteit atan de waterstof-bindingen tussen de * gminozuren.

Amlmozuren Organische moleculen met een carboxyl- (-COOH) en een aminogroep (-NH2). Er bestaan honderden aminozuren, mara slechts 20 daarvan worden in * eiwitten aangetroffen.

Aminozuursequentile De volgorde walarin *aminozuren in *eiwitten voorkomen.

Amnion Een van de vier vliezen die embryo"s van sommige vertebraten (reptielen, vogells en zoogdieren) omhullen.

Anomalle Een verschijnsel dat in strijd is mett een gangbare theorie.

AntIgeen Structuur (bijvoorbeeld een virus) die door het lichaam als vreemd wondt herkend en waartegen het "afweersysteem in actie komt.

Antilichaam "Eiwit dat door het lichaam wordt aangemaakt en zich met een "antigeen kan binden. Antilichamen vormen een onderdeel van het afweersysteem. $Z$ ic ook *immuniteit en * mumulunglobulinen.

Assoclatlepsychologle Empiristische theorie over keniswerwerving volgews welke complexe processen in de geest te therleiden zijn tot combinaties (associatiesi) wan eenwoudige zint uiglijke envaringen. Vergelijk "vermogenspsychologie.

Associatiewelten Wetten uit de $19 \mathrm{e}$ eeuwse "associatiepsychologie warmee het ontstaan van complexe ideeĕn en woorstellingen in de geest werd verklaard. Een wan die wetten fuidde: gelijksoortige voorstellingen hebben de neiging elkaar op te roepen.

Aviditelt Een maat woor bundingskracht tusisen een "antigeen en een "antilichaam. In tegenstelling tot de "affiniteit, is deze mat niet alleen gebaseerd op de associaticuconstante, maar ook op andere fysich-chemische parameters.

Behaviorlsme Amerikaanse psychologische benadlering wat rin wordt benad rukt oat het "object" van psychologisch onderzoek observectbaar en meetbaar gedrag movet zijn. Onderzoek naar subjectieve betewingen door middel van *introspectie wordidoor behavioristen "onwetenschappelijk" genoemd.

Bloedgroepen Typen bloed die op basis van verschillende soorten antigenen welke aanwezig zijn op de rode bloedcellen worden onderscheiden. De bekendste indeling in bloedgroepen bij mensen is het $A B O$-systeem, waarin die bloedgroepen $A, B, A B$ en $O$ worden onderscheiden.

B-Iymfocyten Witte bloedcellen die antilichamen produceren. 
Ce trale dogma De theorie dat de erfelijke informate in ed cel wan DNA via RNA

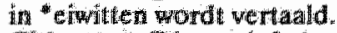

Chimeren Dieren (of planten) warvan de weefsels zijn opgebonmd uit twee werschillende genotypen. Chimeren ontstan doonda in ex vroeg stadium in de ontogenie cellen yan verschillende embryos worden wigewisseld.

Cognilleve gtill Itet web van conventies dat onderzoekers in stat stelt om hun weten. schappeilike bedoulingen op en specifieke manier wit te drukken. Ben stijl opent dus. mogelijkheden, matr legt ook beperkingen op aan de vorm watrin beweringen moeten worden gegoten en op de intichting van argumentaties. "Methodologische stijlen leggen. wast hoe ower cogritieve aangelegenheden moet worden geschreven.

Consthutlet enzym Een enzym dat continu door een cel (bijwoorbeeld een bacterie) wordt arngemalak. Bypoorbeeld de bacterie Escherichia coli produceen voortdureno een enzym dat glucoose afbreekt. Vergelijk adaptiel enzym.

Darwinlsme Evolutietheorie die is ontworpen door Charles Darwin. Volgens deze theorie owerteven door natwurlijke selectie in de strijd om het bestaan dife individuen warvan de variaties (de genetisch bepaalde eigenschappen) aan de omgeving waarin zij) leven beter zijn angepast. Vergelijk *adaptatic.

Deductle Het met behulp wan de regels van de logica afleiden van een uitspraak (conclusie) uit gegeven uitspraken (premissen). Vergelijk inductie.

Disciplinalire matrlax Het geheel van overtuigingen, uitgangspunten, methoden en wainden dat cen onderzoeker zich eigen makt wanneer hij of zij wordt gesocialiseend in een bepaalde discipline. Dit geheel stelt een onderzoeker in staat om binnen die discipline purzels te lossen.

Display Complex gedrag dat door een bepalde diersoort wordt vertoond en als cen specifiek signaal functioneert birnen die soort. Typische voorbeelden zijm soortspecifieke gedragingen, zoals die voorkomen tifdens de balts (paardans) of gevechtem.

DNA (DeoxyriboNuclelc Acld) Nucleinezuur (opgebouwd wit nucleotiden) dat voorkomt in de chromosomen van de celkern en drager is van erfelijke informatie. DNA verschilt wan RNA in het suikermolekiull (desoxyribose) dat zich in bet nucleotide bevindt.

Clwit Verbinding die bestaat uit een aantal *aminozuren die in een bepaalde volgorde met elkatar zijn verbonden. Bepalde eiwitten, zoals hormonen en *enzymen, vervullen belangrijke regulerende functies in organismen.

Emmertheorle "Theorie volgens welke kennis ontstaat doordat de geest langzamerhand wordt gewuld met informatie die via de zimtuigen naar binnenstroomt. Deze enigszins badinerende benaming is bedacht door Karl Popper. Vergelijk *zoeklichtheorie.

Emplrisme Kennistheoretische opvatting volgens welke ware kennis is te herleiden tot zintuiglijke ervaring. Vergelijk * rationalisme.

Enzym * Eiwit dat in een cel een chemisch proces calalyseert. Enzymen kunnen ook buiten de cel actief zilin, bijvoorbeeld bil de voedselwertering.

Eplgenese Deze theorie stamt uit de $17 \mathrm{e}$ eeuw en stelt dat tijdens de ontwikkeling van embryo tot volwassen individu complexe morfologische structuren gelleidelijk ontstaan uit de interacties tussen reeds gevormde structuren. Vergelijk * preformationisme.

Epistemologie Zie "kennistheorie.

Ethogram Een overzictht van de gedragingen die door een diersoort worden vertoond. * Einologen die ethogrammen apstellen veronderstellen dat het gedragsirepertoine van een diersoont eindig is:

Ethologle De biologische benadering van het gedrag van dieren. De madruk in deze benadering ligt op een complete beschrijving en analyse van het gedrag zoals dat door dieren in hun natuurilije omgeving wordt vertoond. Zie ook * elhogram.

Exemplar Maatgevend voorbeeld dat laat zien hoe en theorie in een specifieke situatie toepasbaar is op een probleem.

Falsticathonisme Opvatting volgens welke kennisontwikkeling tot stand komt door climinatie van fouten uit theoriect.

Fenotype De verschijiningsvorm van een organisme. Orgamismen worden bepaald door het *genotype en hun omgeving. Dezelfde genotypen kunnen resulteren in verschillende fenotypen, als de organismen in werschillende omgevingen opgroeien.

Fitmes: De (genetisch vastgelegde) potentive van een organisme om in een bepaalde omgeving te overtleven.

Fylogenle De geschiedenis van de cvolutic van een soort. Vergelijk "ontogenie.

Gecondilloncerde reflex $\mathbb{E}$ en eenvoudige vorm van le ren waarbij een al bestaande reflex geassocieerd rakt met een nieuwe stimulus die, als gevolg van het leerproces, de reflex kan oproepen.

Gen Een basale enheid wan de erfelijkheid. Genen zijn kleine delen van de chrosomen, en bestaan uit stukjes *DNA. Structurele genen bezitten een "genetische code voor de *aminozuurvolgorde van * eixittem. 
Genetlsche cade De code die via de geslachtscellen wan generatie op generatie wordt overgeleverd, en die de "aminozuurvolgorde van "eiwitten bepaalt.

Gemotype De genetische samenstelling van een onganisme. De term wordit gebruikt in contrast met de term " fenotype.

Gestaltpsychologle Psychologische school die in het begin van deze eeuw in Duitsland ontstond. Volgens Gestaltpsychologen kunnen psychologische fenomenen begrepen worden als ze wonden gezien als gestructureerde gehelen (Gestalten'). In onze ervaring zijin deze gehelen duidelijker dan de samenstellende elementen. Wanneer we bijwoorbeeld een melodie horen, dan nemen we de melodie als geheel war en niet alleen de afzonderlijke noten.

Groepsselectle De theorie dat individuen gedrag vertonen dat ten woordelle van de groep is uitgeselecteerd. $Z$ zouden dieren ten gevolge van groepsselectie zich in beperkte mate voortplanten omdat anders de groep waarin zij leven roofbouw zou plegen op de bestaansbronnen in hun milieu. Hiendoor zou de groep als geheel een grotere overievingskans hebben.

Hapteen Een kllein chemisch molecuul dat reageert met een "antilichaam maar niet de productie van antilichamen stimuleert; tenzij het hapteen wordt gekoppeld aan een drager-einwit.

Herltablilty Dat deel van de "fenotypische variatie in een populatic dat kan worden toegeschreven aan genetische variatie.

Heuristiek Regels die aangeven hoe een theorie verder kan worden uitgebouwd. De regels vormen geen ontdekkingsalgoritme, tmaar leveren aanwijzingen hoe wellictht een theorie vruchtbaar kan worden uitgewerkt.

Hollsme Opvatting dal een geheel (bijvoorbeeld een organisme) méer is dan de som van de delen waaruit het is opgebourwd. De functionelle relaties tussen de delien worden waak ais een argument wór deze opvatting aangevoerd. Vergelijk "reductionisme.

Homologie Een centraal begrip uit de vergelijkende anatomie dat wordt gebruikt om de evolutionaire verwantschap tussen morfologische st ructuren aan te geven. Twee morfologische structuren zijn homoloog wanneer de oniwikkeling van beide siructuren gezien kan worden als een modificatie van een gemeenschappelijke grondvorm. Bijvoorbeeld de vin van dolfijnen, de hand van mensen en de vleugels van vleermuizen zijn homoloog, omdat zij alle modificaties zijn van een gemeenschappelijke bouwplan.

Immuniteil Het niet meer vatbaar zijn voor een bepaalde infectieziekte omdat men bijwoorbeld ertegen is gevaccineerd. Immuniteit berust op de aanwezighcid van "antilichamen in het serum (de humorale immuniteit) en op cellulaire immuniteit. Passieve immuniteit ontstaat doordat men antilichamen krijgt toegediend of doordat kinderen antilichamen verkrijgen wan de moedervia de placenta. Actieve immuniteit ontstaat door vaccinatie of door thet doomaken van een infectieziekte.

Immunogenetica Het vakgebied waarin de genetische aspecten van de *immunglobulinen worden onderzocht. De diversiteit in de stroctuur van de verschillende immumglobulinen vormt het belangrijkste onderwerp.

Immunglobuline Is: *antitichaam. Antilichamen worden aangetroffen in de zogeheten globulinefractie van het bloed. Bloed kan via een aantal bewerkingen worden opgesplitst. globulinefractie van het bloed. Bloed katn via een aantal bewerkingen worden opgesplitst. over. Dat bestaat uit water en "eiwitten, waaronder de immuunglobulinen.

Immmuntolerantle $\mathfrak{D e}$ reductie of eliminatie van het vermogen van een individu om op specifieke wijze te reageren op *antigenen. Zo worden foetussen tijdens de ontwikkeling tolerant voor antigenen op de lichaamseigen cellen.

Incommensurablittelt Letterlijk: 'niet-samen-te-meten'. Theorieën zijn incommensurabel wanneer er geen newtrale taal is waarin een atantal termen uit de theoriecen wonder verlies van betekenis kunnen worden uitgedrukt. Aan de voorwwarden van wergelijking van die theorieèn is dan niet voldaan, omdat bij een (logische) vergelijking van theorieên wordt voorondersteld dat de betekenis van termen dezelfde is.

wordt voorondersteld dat de betek Redeneerwijze waarin op grond van een eindige rij van enkelvoudige uitspraken wordt owergegaan tot een algemene uitspraak. Vergelijk •deductie.

Inprenting Een leerproces dat plaatswindt tijdens een vroeg stadium in de ontwikkeling. Zo le ren jonge dieren door inprenting te reageren op bepaalde bewegende objecten; in de natuur is dit meestal cen ouder van het jonge dier.

de natuur is dit ineestal cen ouder van het jonge die rond de eewwowisseling ontstond en waarin wrordt gesteld dat gedrag goeddeels kan worden begrepen als het resultaat van aangeboren disposities tot handelen (instincten). Men veronderstelt bijvoorbeeld dat een kudde-instinct in tijden wan corlog 'in kracht toeneemt".

Instructletheorie Theorie over de produktie van "antilichamen. Volgens dexe theorie is de informatie woor de produktie van een specifiek antilichaam afkomstig van het *antigeen praartegen het is gericht.

Introspectie Psychologische onderzoekmethode naar de inhoud van de eigen mentale ervaring, waarover men een verslag kan uitbrengen. 
In who Onderzok nat biologische procesen dat word verrich buiten levende dirganismen, traditoned in en reageentilis.

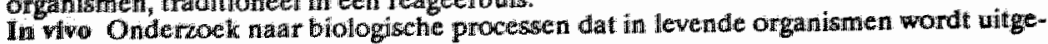
vourd.

Kinnitheorie Het onderdeel van de filosofie dat zich bezighoudt met de gronden, bronnen en rechtvaardiging wan menselijke kennis.

Klonale selectletheorte Theorie ower de produktie van antilichamen. Volgens deze theorie bestaat er voor elk antigeen (preciezer: voor elke antigente deteminant) een corresponderende "kioon van antilichaam-producerende cellen die tot klonale expansie wordt angezet door het antigè

Wloon Groep van cellen die alle van een en dezelfde cel afstammen en dus in genetisch opricht identiek tijn.

Rrilseh ratlonalisme Wetenschapstheorie van Karl Popper. Volgens deze opvalting zijn wetenschappelijke theorieẽn produkten van de menselike geest die altija de status van vermoeden behouden. Wetenschappellike theorieën kunnen volgens Popper aan kritische tests worden onderwerpen maar men kan de waarheid ervan nooit bewijzen.

Lammarchanisine Evolutietheorie van Jean Baptiste Lamarck. Centraal in deze theorie staat de gedachte dat individueed verworven eigenschappen die in een omgeving te pas komen erfielijk worden en zo aan volgende generaties kunnen worden overgeërfd. Hierdoor zouden er geleidelijk verschillende soorten ontstaan.

Laglech empirlsme Fillosolische stroming die in het begin van deze eeuw is ontstian. De logisch empiristen gingen uit van een * empiristische kennistheorie en hanteerden bil hun analyse van wetenschappelijke theorieén de logica als instrument.

Lysus Vernietiging van een cel doordat de membraan van de cel wrordi aangetast. Bepaalde virussen veroomaken na infectie en vermenigvildiging lysis van de gastheercell. Membran Dun vlies dat bijwoonteeld de celvloeistof van een cel omgeeft. Celmembranen zijn opgebouwd wit voomamel lijk lipiden en "eiwitten.

Methodologie Onderdeel wan de wetenschapsfilosofie, dat zich bezighoudt met een reconstructie van de wetenischappelijke methode. De wetenschappelijke methode is de weg die lieidt tot "ware" kennis.

Monoklonale antllichamen Antilichamen van cén en dezelfde soort, wrelke worden uitgescheidlen door een "kloon van cellen. Ze kunnen "in vitro worden gemaakt door een *antilichaam-producerende cel te fuseren met een kankercel.

Mutatle Verandering in de structurur van het DNA (gen-mutatie) of in de hoeveelheid chromosomen (chromosomale mutatie), die tesullteert in een werandering in een eigenschap van een organisme. Wanneer een mutatie optreedt in de ganeten (geslachtscellen) is de mutatie overerfbar. Vindt de mutatie plaats in andere cellen (somatische cellen) dan is de mutatie niet overerfbaar (somatische mutatie).

Normale wetenschap Fase in de on twikkeling van wetenschap waarin overeenstemming heerst tussen onderzoekers over bet type problemen dat met een algemeen aanvalarde theorie kan worden opgelost. "Anomallieén komen in deze fase slechts spaarzaam voor of wonden niet als zodanig herkend. Vergelijk * revolutionaire wetenschap.

Nucleotlde Molekuul dat bestaat uit een stikstof-houdende base (een purine of een pyrimidine) werbonden met een suiker en een fosfaatgroep. Nucleinezuren ( DNA en - RNA) bestarn wit lange ketens van nucleotiden.

Oecologle Tak van de biologie waarin de relaties tussen organismen onderling en hun milieu wordt onderzocht. Bijvoorbeeld de relaties tussen predatoren (roofvijanden), hun prooien en het milieu waarin zij leven.

Onlogenle De ontwikkeling vain een undividu tijdens zijn of haar leven. Vergellik tyllogenie.

Optimaltsntletheorte In een evolutionair kader is dit de theorie die stelt dat díe eigenschappen van organismen evolueren waarvan de baten hoger zijn dan de kosten. Deze theorie is binnen de oecologie wiskundig uitgewerkt en vooral toegepast op voedselzoekged rag.

Peptlden Sloffen die bestaan vit twee of meer *aminozuren (de bouwstenen wan eiwitten) die verbonden zijn door covalente bindingen tussen de aminogroep ( $\mathrm{NH}$ ) van het ene aminozuur en de carboxylgroep (-CO) van de volgende. Pollypeptiden bestaan wit drie of meer aminozuren.

Populatlegenetlca Vakgebied waarin de de veranderingen in *fenotypische variaties als gevolg van genetische variaties worden onderzocht.

Preformmationlsme 17e ceuwse theorie die stelt dat alle morfologische structuren al in beginsel aanwezig zijn in bijwoorbeeld een menselijke geslachtscel (eicel of zaadcel) en tijdens de ontwikkeling tot volwassene alleen maar groeien. Preformationisten dachten dat in de geslachtscel een homunculus (miniatum $r$ van een mens) aanwezig is. Vergelijk "epigenese.

Proximate oorzaken De oorzaken van verschijnselen tijdens de *ontogenie. Vergelljk

-ultimate corzaken. 
Rationalisme Kennistheoretische opwatting die stelt tat kennis te funderen is in onbetwijfelbare principes in de geest. Zintuiglijke ervaring speelt in dezc opvatting bij het verwerven van kennis een ondergescllikte rol. Vergeilik "empirisme.

Recapllulatietheorie "Theorie die slelt dat de *ontogenie een wersinelde herhaling is van de "fylogenie; dat wil zeggen dat organismen tijdens hun ontwikkeling de stadia in de evolutie van de soort nog eens doorlopen.

Recombinant DNA technologie Techniek waarbij erfelijk materiaal (*DNA) van het ene organisme in de chromosomen van een ander organisme wordt aangebracht.

Reductionisme De opvatting dat cen geheel kan worden begrepen alls een functie van de samenstellende delen waaruit het is opgebouwd. Vergelijk "holisme.

Releaser Een stimulus die een soortspeeifiek gedragspatroon oproept. Een 'social releaser" is een gedragspatroon dat bij een soortgenoot een bepaalde reactie oproept. De ethologen Lorenz en Tinbergen postuleerden dlat het reagerende organisme een 'innate releasing mechanism' bezit, i.e. een aangeboren neurosensorisch nechanisme waardoor het organisme op cen specifieke wijze reageert.

Revolutionaire wetenschap Fase in de ontwikkeling wan een wetenschapsgebied die ontstaat nadat onderzoekers onderkennen dat de gangbare theorie niet meer geschikt is om thet steeds groeiende aantal * anomalieèn te verklaren. In deze fase gaan onderzoekers op zoek naar een nieuwe theorie die de anomalieên well kan verklaren. Vergelijk "normale wetenschap.

Ritualtsatie Proces tijdens de evolutie waardoor bepaalde soortspecifieke gedragingen een andere functie krijgen. Bijwoorbeeld, bepaalde complexe gedragingen ("displays) die tijdens de balts door vogels worden wertoond lijken veel op elementen uit het agressief gedrag. Daarom veronderstelt men dat dic gedragingen uit het agressief gedrag zijn geëvolueerd.

RNA (RiboNuclelc Acld) Nucleïnezuur in de cell dat onder andere betrokken is bij de aanmaak van *eiwitten. RNA verschilt van "DNA doordat de "nucleotide een ribosemolekuul (suiker) bevat.

Sample Een standaard van vergelijking. Bijvoorbeeld kileurkaarten worden als standaarden van vergelijking gebruikt bij het onderseheiden van kleuren. De kleurkaarten functioneren hierbij als standaarden voor juiste en foute cordelen.

Socloblologie De biologische benadering van sociaal gedrag. In thet sociobiologisch onderzoek staan die evolutionaire processen centraal waardcor sociaal gedrag ontstaat en gehandhaafd blijft. Verklaringen worden vaak gegeven in termen van "speltheoretische modellen.

Specificlicit De term wordt veelvuldig gebruikt in de levenswetenschappen om de unicke relatie tussen een bepaalde stimulus en een reactie aan te geven.

Speltheorle Oorspronkelijk een wiskundige benadering waarin men zich bezig houdt met formele analyses van besluitvormingsprocessen. Bij speltheoretische analyses van besluitvormingsprocessen ligt de nadruk op de confictsituaties die ontstaan doordat de spelers op grond van tegengestelde belangen uit verschillende opties kunnen kiezen. De speltheorie wordt onder andere toegepast in de economie, sociale psychologie en de sociobiologie.

Syrinx Het orgaan waarmee vogels geluiden produceren.

Test psychologie Benadering in de psychologie waarin de vermogens van mensen aan de hand van regeis of procedures worden onderzocht. Zo onderzoekt men bij een intelligentie-test de cognitieve vermogens van mensen door hen problemen of puzzels voor te leggen.

Uilimate oorzaken De oorzaken van verschijnselen tijdens de *fylogenie. Vergelijk "proximate corzaken.

Pergellykende psychologle Subdiscipline binnen de psychologie watarin de verschillen th overeenkomsten tussen dieren en mensen worden onderzochi. In cerste instantie lag de nadruk in deze subdiscipline op een vergelijking van de leerprocessen bij verschillende diersoorten.

Vermogenspsychologie Psychologische stroming wit de $19 \mathrm{e}$ ceuw waarin werd gestcld dat de geest is uitgerust met een cindig aantal vermogens zoals de wil of de rede. Mentale processen zouden volgens deze theorie in temen van deze vermogens kunnen worden verklaard. Vergelijk "associatiepsychologie.

Vitallsme Opvatting dat levende organismen te onderscheiden zijn van niet-levende dingen omdat zij een levenskracht bezitten. Fysische en themische principes zijn volgens vitalisten niet voldoende voor de verklaring van het verschil tussen leven en niet-leven.

Zoeklichtiheorie Theorie over kenniswerwerving die stelt dat de geest is witgerust met bepaalde vermogens en disposities. Volgens deze theorie wordt de we reld altijd door de bril van een theorie waargenomen. Vergelijk * emmertheorie.

Zygate Cel die ontstaat door de fusie wan twee gameten (geslachtscellen). 


\section{Personenregister}

Anderson, M. 133, 135

Aristoteles 51

Atratedi (G. 155

Axelirod, $R, 136,166,168-171$

Bater, G.P. 104

Bartlet, $F^{\prime} C$. 177.179

Bateson, P.P.G. 122, 123

Beer, G.R. die 125

Bence Jones, H. 160

Billingham, $\mathrm{RE}: 150$

Binet, A 180, 180

Bohr, N.H.D. 152

Boon, $L .30,31$

Bossema, 1. 137

Boyd, W.C 12

Breinl, F. 142-144

Brenner, $\mathrm{S}, 18$

Brent $\mathrm{C} 150$

Bithler, K. 57,132

Burgler, R.R 137

Burriet, F.M. 11-13, 46, 115, 140, 147 . $151,153-156,162$

Campbell, D.H. 145, 146

Camap R. 90,91

Caryi, P.G. $135-137$

Cháin, E 40

Chang, T.S. 150

Coghil, G.E 72,73

Conner, $S .105$

Crick, $F, 31,141,145,151,159,162$, $164,187,191$

Darwin, C. 16, 17, 20,34,55,57,60, $105,110,112,131,166,167,186$, $187,191,196$

Dawkins, R. 22, 135

Delbrück, M. $14,151-153$

Dreyer, G. 39

Driesch, H. 126

Dunham, D.W. 133,135

Ebbinghaus, H. 177, 179

Edelman, G.M. 159, 160

Ehrlich P. 115, 140,142

Eibi-Eibesfeldt, 1. 67, 82, 83

Einstein A 51

Engllberger, P.M. 157

Fenner, P. 148

Fisher, R.A. 20, 21, 127, 128

Fileischer, S. 157

Flening, A. 37-41,46, 47, 105

Florey, TI.W. $38-40,46,165$

Gatileü, G. 51,88

Gallo, R. 105

Gally, J.A. 1160

Galton, F. 180

Gamow $_{\text {i. }} .19$

Glick, B. 150

Good, R.A. 150

Gottlieb, G. 51, 74-80, 82, 83, 108, 109, 122,124

Gowanis, J. 150

Haber, E. 158

Hacker, P.M.S. 104

Haeckel, E 125,126

Hamburger. V. $51,72-75,80,82,83$

Hamilton, W.D. 136

Hamlin, M. 155
Hanson $N$ R 90

Haraway, DJ. 85

Harber, $\mathrm{H}, 183$

Mairwood, 3. 182,183

Hasek, M. 150

Haunowitz, $F$. 12,142-144, 156, 161

Mebb, D. O, 28, 50,67

Heidelberger, M. 114, 116

Hinde. R $\mathbb{A}, 70,71,136$

Hiramoto $\mathbb{R}$ N. 135

His, W. 126

Holst $\mathrm{E}$ won 73

Hoofl, J.A.RA.M. $\operatorname{van} 167,169,173$

Jaap, R.G. 150

Jacob, F. 187

Jensen A.R. 182

Jerne, N.K $11,12,115,116.140,147$, $151-154,156,160,162,187$

Karush, F: 43

Kepler, J. 88

Kingman, S. 105

Köhler, G. 155

Köhler, W. 175-178

Koshland M.E. 157

Krebs, J.R 135

Kripke, S. 86

Kuhn, T.S. $30,31,36,37,42,44,45,51$ $54,62,81,101,110,192$

Külpe, 0.16

Kuo, Z-Y. $50,51,54,62-68,70-72,74$ $78,81-83$

Lack, D. 127

Lakatos, 1. 124, 131, 135

Lamarck, J.B. 16, 125, 187, 196

Landsiciner, K. $19,113,142,144,146$

Latowr, B. 105

Lederberg. J. 154-1.56

Lehrman, D.S. $50-52,66-71,74,78,79$, 82

Lewontin, R. 23, 25, 187

Loghem J.J. van 12

Lorenz $K .18,25,50-52,54,55,57-60$, $65-71,77,79,81,131,132,193$

Luria, S.E. 14

MacArthur, R.H. 127, 128

MacFarlane, G. 40

Mach, $\mathbb{E} .90^{\circ}$

Mackenzie, B.D. 62

Mäkelä, 0 . 155

Marrack J.R 114, 116

Maynard Smith "J.' 128-130, 133-135, 137,138

McDougzall, W. 58

MeVicker Hunt, J. 82, 83

Medawar, P.B. $149,150,187$

Mendel. G. 60

Miller J. 150

Milstein, C. 155

Mirsky, A.E. 144

Monod, J. 14

Montagnier, L, 105, 106

Morgenstern, 0 . 128

Muda, S. 144

Newton, 1. 34, 51,88

Newmann, Ji von 128

Nordin A.A. 155

Nossal G.J.V. 154, 155

Oppenheim, R. 51,75-77,80

Owen, R.D. 149

Parker, G.A. 129, 130 
Paul, D. 181

Pauling, L. 19, 114-116, 144-146, 153, $157,162,190$

Pavlov, 1.P. 55, 56

Pearson, K 180

Pittendrigh, C.S. 125

Plato 197

Popper, K.R, 14, 15, 25-27, 30-39, 41 $42,45,48,49,86,87,89,90,92,93$, $112,117-119,165,188,189,192$. 195-198

Porter, R.R. 145, 157

Prever, W. 72

Price, G.R. 128, 130

Putnam, H. 86

Rhijn, J.G. van 136-138

Rothen, A. 144

Roitt, I. 155

Roux, W. 126

Russell, B.A.W. 90

Sanger, F. 158, 159,162

Scheer, J. van der 142

Schlick, F.A.M. 91

Schneirla, T.C. 50, 51, 65-67, 71, 74, 78,79

Shapin, S. 86

Simon, "Th. 179

Simonsen, M. 150

Smith, E.L 157, 158

Stent, G. 152

Stokes, A.W. 133, 135

Talmage, D. 148,154

Tanford, C. 158

Thorndike, EL. 176-178

Tinbergen, N. 18, 50, 51, 59, 64, 70, 71, $111-113,132,134,166-169$

Tolman, E.C. 71

Tonegawa, S. 161

Vodegel, $\mathbb{R} .136,137$

Waismann, F. 91, 94

Watson, J.B. $54-57,59,60,62,63,77$, $79,81,192$

Watson, J.D. $31,145,151,152,153$

Whitney, P.L 158

Williams, G.C. 133

Wilson, E. O. 23, 25, 122

Windle, W.F. 72, 73

Wittgenstein L.' 27, 87, 89-91, 93-103, $106,107,12,189,195-197$

\section{Zakenregister}

aanlegtheorie $11-14,17,19-22,23-28$, $48,85,119,130,140,147,186,187$ 189

achiemgrond kennis $41,42,44,85,111$, $112,181,193$

adaptieve emzymen $14,140,147,148$, 151,187

ad how werandering 45

afbeeldingstheorie $93,98-100$

affiniteit $44,114-117,143,146,152$

angollutinatie 143

alpha-helix 145

aminozuursequentie $144,146,157-161$

amnion 64,75

anomalie $39,44,45,48,53,131,135$, 136,153

antropomorfiseren $55,56,57,134$

antigeen $11-13,43,44,113-116,141$. $149,152,154,157$

antilichaam 11-13,43,44, 113-116 $141-146,148,149,152-155,157-161$ 163

associatie $14,15,17,24,26,176$

associatiepsychologie $15,17,25,60$, 176,177

aviditeit $115-117$

Baconiaanse traditie 30

basisuitspraak $33,89,119,189$

behaviorisme $20,25,28,54-57,59-62$, $65,71,72,79,81,172,173,176,177$, 192

Bence Jones eiwitten 160,163

bloediaroepen 149,150

B-lymiocylem 155

centrale dogma $141,164,154,191$

chimeren 149

comditioneren $24,56,66$

conflicthypothese $132,133,167$

context of discovery 32

context of justification 32

Darwinisme 16,17

deductivisme $18,19,32,34,42,188$

deductieve stijl, benadering $13,19-28$,

$30-37,41-43,46-48,87,89,92,93$.

$109,118-121,123,130,131,134$,

$144,145,151,162-164,171,188-192$

disciplinaire matrix $52,54,59,62,81$, $1 b_{2}$

display $134,136,137$

DNA 30, 31, 140, 145

ecologische validiteit 177

embryologic $84,85,126,187$

embrollogie van gedrag 64,71-80 $107,108,119,121$

emmertheorie $14-19,23,24,27-32,48$, $93,106,108,117,119,188,192,195$

empirisme $13,15-19,88,89,106,107$

empirische basis $87,89,90,105,106$

epigenese $16,17,161$

epigenese 18, $25,28,29,54,57-62,65$ $79,81,127,131-139,141,165,192$

ethogram $61,62,169$

evolutionair stabiele strategieèn 21 . $22,123,128-130,134-139$

evolutietheorie $16,17,55,60,112,125$. $167,186,196$

exemplar $52,53,82,110,145$

experimenterende traditic 30 
1falsinicatie 33,92

Diturese $20,128,129$

functionallstische benadering 116 , 141, $147,156,159,162-164,177$, $191,194 *$

fylogem $125,126,161,167,193$

fysische chemie 142,146

geconditioneerde reflex 56,61

gehengenondertok 177,178

genetische code 18,159

Gestaltpsychologie 177

graminaticalle regels $95-98,100,101$. $102,103,112,113,189$

grocpsseledte 133

litaptenen 113,114, 142,145, 146 Havik-Duif model $128-130,134,138$ heritability 181

heuristiel $124,131,137,138,145,151$, 180,18

hollisme 84, 117

homologie $59,175,167$

humane elhologie $166-169,171-177$, 194

humane socloblologie 169-171

immunologie $11-13,19,21,26,43,113$ $119,121,140-164,190,191$

imuinglobuline $144,146,156-161$

immuuntolerantive $149,150,153$

incommensutabillteit $52,54,59,62$

inductivisme $18,19,34,35,42,119$, 120,188

inductieve still, benadering 13,19-28, $30-37,4128,60,86,87,92,109,119$ $121,134,143,162,166,169,184$ 188,189

informatict raditive 158

innate releasing mechanism $13,59,71$

inprenting 78,79

insuline 158,159

instinct $55-59,62-66,80$

instinctpsychologie $16,57,58$

instructic door ther halling 14, 16, 17, 25

instructietheorie $11-13,29,46,114$, $117,140-147,156-158,187$

intelligentie-onderzoek $29,166,175$ 184

interactionisme $80,85,86,193$

introspectie 56

kionale selectietheorie $11-13,29,46$, $1118,140,154 \times 156,187$

krtisch rationalisme $31,32,34,89$, 196. 197

Lamarckianisme 16,17

lonisch atomismice 93,94

logisch empirisme $27,32,33,87,89.93$ lysts 40

mathematische tractic 30

nentale $73,176-178$

moleculaine biologie $18,140,141,151$, 158, 198

momoklonale antitichamen 118,121 , 155,163

monste ratan passingen $135-137$

monsterassimilaties $135-137$

natum-cultuur problematiek 166,180 183

natumurlyjke selectietheoric 140,151 . 153

normale wetenschap $42,43,52,81,109$ aecologie 127

onigewingstheorie 11-14,17, 19,20-27, $49,85,119,147,183,186-190$ ontogenie $69,70,123-126,149,161$,

optimalisatietheorie 127,128

astensieve definitues: $90,91,93-98$

onderwijssociolagie 183

penicilline, ontdekking van $37-41,46$

populatilegenetica $23,127,187$

preformationisme $16,17,20,161$

Prisoner's Dilemma $137,169,170$

proble emoplossen $27,43,45,47,81$, $82,189,193$

proximate oorzaken $123-126,193$

puzzeloplossen $36,42,45,47,49,52$,

$81,82,108,110,119,189,193$

rationalisme $13,15,16,18,19,88$

recapitulatietheorie 125,126

recombinant DNA techniek 118,163

rech tvaa rdigingspraktijk $19,33-37,41$, 107

reductionisme 84,117

regellgeleid gedrag 179

releasing factor 13

response $11,13,56,57,61,76,81,153$ 157

rewollutionaire wetenschap $59,81,82$

rilping $15,17,60,66,68,71,79$

RNA 159

sample $39,46,95-98,102-113,116,118$ -

$121,138,141,155,158,160,163$,

$164,166,179,186,189-198$

sexe-verhouding $20,21,127$

soctiobiologie $20,22-24,26,28,29,122$, $126-13 \mathrm{~F}, 133-138,141,187,191$

specificiteit $13,14,43,113,114,141$ 143,146

speltheorie $24,128-139,165,169-171$, 190

statistick $105,180,181$

stimulus $11,17,24,56,57,61,63,63$, $76,76,78,81,138,149,176$

stinnulus-response-mechanisme $61-63$, 78

structuralistische benadering 43,117 ,

$141,147,156,159,162-164,177$. 191,194

syrinx 78

testen wan hypothesen $42-44,111-113$

testen van theoricen $23,31-34,41-43$

testpsychologie $180 \mathrm{~m} 184,194,195$

trial and error $14,17,25,176$

trigger $11,15,17,24,38,140,154$

ultimate oorzaken 123-126, 130, 1193

vergelikende morfologie 126

vergelitkende psychollogie $50,64,65$

verificatie $90-92$

vermogen $14-17,108$

vermogenspsychologie 15,17

vitalisme 84

wet van de contuguiteit 15

Wiener Kreis $89^{\circ}$

wiskunde 21,152

zellprikkeling $74,75,78,86,140,142$

zijketentheonte 140,142

zocklicht theorie $14,19,23,24,27,28$, $30,32,48,92,93,102,108,117,119$ $188,189,192,195$ 


\section{Summary}

The nature-nurture problem is the subject of debates in the life sciences and the philosophy of science. In the life sciences, hereditarian explanations of phenomena are contrasted with environmental explanations. In the philosophy of science, rationalism is traditionally contrasted with empiricism, or, in modern methodological terms, deductivism takes issue with inductivism. The essence of these conflicting explanations between hereditarian and environmentalist theories, and of the contrast between deductivism and inductivism, has been described by K.R. Popper in the Bucket- and the Searchlight theories of the mind. According to the (empiricist) Bucket theory the mind is empty at birth, and subsequently filled with information received through our senses. Sense experiences form the basis from which general knowledge is inferred by induction. According to the (rationalist) Searchlight theory the mind is prestructured in such way as to be constitutive of at least the form of our knowledge, or, in the strongest version, to contain knowledge itself. In the latter case sense experience is only a trigger-mechanism. The fundamental opposition of these theories consists in the contrast between two basic explanatory schemes for the acquisition of general knowledge: instruction through repetition (Bucket theory) versus selection by trial and error elimination (Searchlight theory).

These views reappear, in all sort of guises, in the philosophy of science and in the life sciences. The evolutionary theories of Lamarck and Darwin are good examples of the latter. Lamarck's theory is representative of the empiricist strain, as the environment in that theory instructs the course of evolution. Darwin's theory is typical rationalist as inherited, and hence, already present, dispositions form the material of natural selection. As the basic explanatory schemes of heriditarian (or environmentalist) theories in the life sciences and the deductive (or inductive) methodology are structurally related, there are connections between 'substantial' theories and methodological styles of explanation. Heriditarians will adhere to the deductive style, whereas environmentalists will prefer the inductive style. These connections between 'substantial' theories in the life sciences and methodological styles of expla- 
nations are further examined in this study. Therefore methodological problems and developments in the life sciences are studied in detail.

Chapters 2 examines the contrast between the deductive and inductive style of explanation. According to Popper the inductive style cannot predominate in the development of science. As inductive inferences cannot be logical (and epistemological) justified, Popper concludes that all developments in science can be reconstructed in terms of his deductive methodology. This position is criticized in chapter 2 . Besides a deductive style, an inductive style is institutionalized in scientific practice. This style however is not organized as would be expected on the basis of the inductive philosophy. The central character of this philosophy, i.e. inductive inferences, does not form an essential part of the inductive style. Moreover hypotheses are not grounded in observation. Crucial for an adequate understanding of this style is the role of background theories. As hypotheses are developped by reformulating research problems in terms of background or accepted theories, such hypotheses are not deduced from a theory, as is the case in deductive problemsolving. Background theories determine the rules of the inductive style but are not criticized. The essence of the inductive style may be accurately described in terms of Kuhnian puzzlesolving.

This methodological critique of the ideas of Popper is extended with a critique of his Searchlight theory of the mind. According to this theory all observation statements are theory-loaded. However in scienctific practise not all statements function as hypotheses (nor are they justified by perceptual experiences, as is assumed by the Bucket theory of the mind). A further analysis of this problem of the empirical basis is done in chapter 4. The ideas of the philosopher $L$. Wittgenstein are used to explain the function of representation methods in science. Especially the notions samples and rules are of great use since these notions may be used to the explain the actions of scientists in the local research context. Furthermore these notions may be used to distinguish various ways of puzzlesolving as samples and rules are frequently used in experimental practises.

With the help of the methodological distinctions between the deductive and inductive style several developments in the life sciences are described in chapters $3,5,6$ and 7 . First, the question is posed whether the opposition between hereditarian and environmentalist theories is solved within the field of animal behaviour. To answer this question Chapter 3 examines two controversies between behaviorists and ethologists. It is argued that the dichotomy between nature and nurture is indeed solvable through puzzlesolving, although the theoretical contrast remains. On the level of testing hypotheses by preparing samples and 
rules in experimental situations, the conflicts between ethologists and behaviorists are superseded. However the theoretical contrast remains as heriditarian and environmentalist theories still function as background knowledge for interpretations of concrete data. This explains why scientists are often seduced to the nature-nurture dichotomy when they are invited to discuss the nature-nurture problem in theoretical terms. It is no coincidence that the so-called interactionist hypothesis is defended with reference to experimental realism.

Chapters 5 and 6 examine differences in developments in the life science, the natural sciences and the behavioural sciences. Controversies in the borderlands between sociobiology and ethology, and between proponents of the biological and chemical approach within immunology, are discussed. The usefulness of the distinction between the deductive and inductive style for analyzing controversies is illustrated by relating this distinction to opposing approaches in the life science, as the opposition between ultimate-causal theories and proximate-causal theories, and the contrast between structuralist and functionalist approaches. The specific connections between such approaches and methodological styles are discussed and the consequences of these connections for the nature-nurture problem are analyzed. Although such connections do result in contrasting theories, samples may enhance consensus among representatives of opposing theories. The way samples enhance consensus however differs per specialty: within immunology for example samples are experimentally created while this is lacking in ethology and sociobiology.

Chapter 7 examines the use of the notions samples and rules for the explanation of differences between developments in the life science and the behavioural sciences. It is argued that ethologists have a special position within the behavioural sciences, which is made possible by one of the logical spaces of the concept of emotion. As emotions have characteristic expressions in the behaviour of man and animals, ethologists are in the priviliged position to study the species-characteristic expressions of emotions. This explains why ethologists are able to develop evolutionary puzzles. Psychologists, by contrast, do not study intelligent behaviour in an ethological manner. Specific controversies, as the controversy between behaviorists and mentalists, may be passed by ethologists, but still haunts psychologists as samples for psychological phenomena, which might enhance agreement in debates, are lacking.

It is concluded that the nature-nurture problem is far more complex as might be expected on the basis of Popper's Bucket- and Searchlight theories of the mind. Chapter 8 examines this increase in complexity. Specific positions in nature-nurture debates are systematically explai- 
ned in terms of the methodological framework developped in this study. Finally the current state of the nature-nurture problem is discussed. It is concluded that the nature-nurture problem is solvable as an empirical puzzle, but remains however a controversial problem. 


\section{Over de auteur}

Harry Smit (1955) studeerde biologie en filosofie aan de Rijksuniversiteit Groningen. Hij was daarna verbonden aan de Faculteit der Wiskunde en Natuurwetenschappen van de Katholieke Universiteit Nijmegen. Sinds 1985 werkt hij bij de vakgroep Gezondheidsethiek en Wijsbegeerte van de Rijksuniversiteit Limburg. 